THALITA RODRIGUES MICHELUCCI MACHADO

Alterações neuroimunes induzidas em camundongos machos pela convivência com um companheiro doente 
THALITA RODRIGUES MICHELUCCI MACHADO

\section{Alterações neuroimunes induzidas em camundongos machos pela convivência com um companheiro doente}

Tese apresentada ao Programa da Pós-Graduação em Patologia Experimental e Comparada da Faculdade de Medicina Veterinária e Zootecnia da Universidade de São Paulo para obtenção do título de Mestre em Ciências

\section{Departamento:}

Patologia

Área de Concentração:

Patologia Experimental e Comparada

Orientador:

Prof. Dr. João Palermo-Neto

São Paulo 
Autorizo a reprodução parcial ou total desta obra, para fins acadêmicos, desde que citada a fonte.

DADOS INTERNACIONAIS DE CATALOGAÇÃO-NA-PUBLICAÇÃO

(Biblioteca Virginie Buff D’Ápice da Faculdade de Medicina Veterinária e Zootecnia da Universidade de São Paulo)

Machado, Thalita Rodrigues Michelucci

Alterações neuroimunes induzidas em camundongos machos pela convivência com um companheiro doente. / Thalita Rodrigues Michelucci Machado. -- 2013.

147 f. : il.

Dissertação (Mestrado) - Universidade de São Paulo. Faculdade de Medicina Veterinária e Zootecnia. Departamento de Patologia, São Paulo, 2013.

Programa de Pós-Graduação: Patologia Experimental e Comparada.

Área de concentração: Patologia Experimental e Comparada.

Orientador: Prof. Dr. João Palermo-Neto.

1. Neuroimunomodulação. 2. Imunidade inata. 3. Estresse psicológico. 4. Dimorfismo sexual. 5. Tumor de Ehrlich. I. Título. 


\section{ERRATA}

MACHADO, T. R. M. Alterações neuroimunes induzidas em camundongos machos pela convivência com um companheiro doente. 2013. 147 f. Dissertação (Mestrado em Ciências) - Faculdade de Medicina Veterinária e Zootecnia, Universidade de São Paulo, São Paulo, 2013.

Página

Página de Parágrafo 3으
Onde se lê Tese

\section{Leia-se}

Dissertação 


\section{Comissão de Ética no uso de animais}

\section{CERTIFICADO}

Certificamos que o Projeto intitulado "Participação do Sistema Nervoso Autônomo Simpático e do eixo Hipotálamo Pituitária Adrenal nas alteraçôes neuroimunes induzidas pela convivência com um companheiro doente", protocolado sob o $\mathrm{n}^{\mathrm{o}} 2404 / 2011$, utilizando 408 (quatrocentos e oito) camundongos, sob a responsabilidade do(a) Prof. Dr. João Palermo Neto, está de acordo com os princípios éticos de experimentação animal da "Comissão de Ética no uso de animais" da Faculdade de Medicina Veterinária é Zootecnia da Universidade de São Paulo e foi aprovado em reunião de 26/10/2011.

We certify that the Research "Participation of the Sympathetic Autonomous Nervous System and Hypothalamic Pituitary Adrenal axis in neuroimmune changes induced by a cohabitation with a sick cage mate", protocol number 2404/2011, utilizing 408 (four hundred and eight) mice, under the responsibility Prof. Dr. João Palermo Neto, agree with Ethical Principles in Animal Research adopted by "Ethic Committee in the use of animals" of the School of Veterinary Medicine and Animal Science of University of São Paulo and was approved in the meeting of day $10 / 26 / 2011$.

São Paulo, 27 de outubro de 2011.

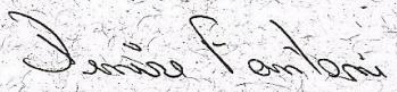

Denise Tabacchi Fantoni

Presidente 


\section{FOLHA DE AVALIAÇÃO}

\section{Autor: THALITA RODRIGUES MICHELUCCI MACHADO}

Título: Alterações neuroimunes induzidas em camundongos machos pela convivência com um companheiro doente

Dissertação apresentada ao Programa de Pós-Graduação em Patologia Experimental e Comparadada da Faculdade de Medicina Veterinária e Zootecnia da Universidade de São Paulo para obtenção do titulo de Mestre em Ciência

Data:

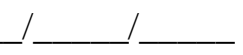

\section{Banca Examinadora}

Prof. Dr.

Instituição: Julgamento:

Prof. Dr.

Instituição: Julgamento:

Prof. Dr.

Instituição: Julgamento: 
Ao Professor Doutor João Palermo-Neto, palavras não são suficientes para expressar o tamanho de minha gratidão, sinto-me lisonjeada de ter sido sua orientada. Além de ser um exemplo de profissional, com um grau de conhecimento e determinação singular, é uma pessoa especial principalmente pela cordialidade. Obrigada pela oportunidade, pela confiança, pelos ensinamentos $e$ pela paciência que teve ao conduzir todo este trajeto. Enfim, obrigada por ter me proporcionado a realização de mais um sonho em minha vida, por estes e inúmeros outros motivos dedico esta obra à você.

Muito Obrigada! 


\begin{abstract}
À minha irmã Joyce Rodrigues, que sempre me apóia incondicionalmente em qualquer caminho que decido seguir, obrigada por ser irmã de verdade, não apenas de sangue, mas sim o principal: de alma! Te amo!
\end{abstract}

E finalmente, aos meus pais, Lourdes e Ademir, que foram os responsáveis pela força que tive por todo este caminho, sempre me apoiando e me fornecendo todo subsídio necessário. Obrigada pela confiança, pela dedicação, pelo amor incondicional, pelo carinho e atenção por todos os anos de minha vida. Obrigada por todo investimento em minha educação, acreditando sempre em mim! Enfim, Obrigada por todo o aprendizado e por sempre me darem a crença que desistir de sonhos não vale à pena. EU AMO MUITO VOCÊS! 


\section{Agradecimentos}

À Fundação de Amparo à Pesquisa do Estado de São Paulo (Projeto Tematico - $\mathrm{n}^{\circ}$ 2009/51886-3; Bolsas - n² 2009/52487-5 e n²011/23391-0) e ao CNPq (Projeto Universal n $470776 / 2009-9)$ pelo suporte financeiro, que permitiu a execução deste estudo.

À CAPES pelo auxílio financeiro por todos estes anos, sendo possível a execução de todas as etapas do meu estudo.

À Faculdade de Medicina Veterinária e Zootecnia e ao Departamento de Patologia, pela formação e estruturas.

Ao Prof. João Palermo Neto por ter me proporcionado mais uma realização de minha vida, serei eternamente grata.

À Prof. Dra. Cris Massoco por todo o suporte e dedicação, sempre disposta a me ajudar e tirar minhas dúvidas da forma mais amigável que conheci, com certeza você fez este caminho mais suave a ser caminhado.

A Prof. Dra. Silvana Lima Gorniák, chefe do Programa de Patologia Experimental e Comparada, pelas idéias e apoio nesses anos.

Ao Prof. Dr. Jorge Florio por me ajudar em uma das principais etapas deste trabalho.

Ao Prof. Dr. Frederico Pinto pelos conselhos e pelas discussões sobre meus estudos.

À Dra. Glaucie Alves, pela coorientação e por me apoiar e ajudar sempre em todos os sentidos.

Às secretarias do VPT, em especial à Cris (Programa de Patologia Experimental e Comparada), por toda a ajuda tanto profissional quanto pessoal, sua presença foi muito importante para mim, obrigada por tudo mesmo.

Aos técnicos do Laboratório de Farmacologia e Toxicologia do VPT: Dra. Nicolle, Vagner e Herculano pelo auxilio na realização dos experimentos.

À todos os funcionários do biotério, em especial: Idalina, Luciana, Claudia e Aline, que me ajudaram sempre na execução dos meus experimentos, obrigada pela atenção e carinho. 
A todos os funcionários do VPT, peças essenciais para o bom funcionamento deste Departamento, que direta ou indiretamente contribuíram com esta dissertação.

A todos os funcionários da biblioteca (FMVZ-USP), em especial à Elza e Helena, sempre dispostas a ajudar.

Ao Rodrigo por estar sempre presente e disposto a nos auxiliar com os processos burocráticos e, claro, pela amizade construída.

Aos funcionários da secretaria de pós graduação, pelo atendimento e atenção por todos estes anos.

A todo grupo de neuroimunomodulação: Adriana Tiemi, Atílio Calefi, Adriano Zagar, Ana Paula, Bruno Honda, Carol Costola, Eduardo Kenji, Glaucie Alves, João Gimenez, Milena Lobão, Poliana Gomes, Viviane de Paula. Em especial: Wanderley Quinteiro, Daniel Nato, Thiago Aloia, Thiago Kirsten, Daniel Gimenes, Lilian e Thiago Marinho.

Ao Dr. Wanderley por toda ajuda e amizade desde o início ao fim desta trajetória. Muito obrigada mesmo, você foi peça fundamental para meu aprendizado e conclusão deste trabalho.

Ao Dr. Daniel Nato, por toda ajuda e dedicação neste trabalho e por dividir seus conhecimentos cordialmente.

Ao Dr. Thiago Aloia, por me ajudar em uma das etapas mais difíceis deste trabalho, e pela disposição e dedicação em solucionar minhas questões

A todos os meus colegas de pós graduação: Vanessa, Fernando Pípole, Isabel, Rafael, Luciana Lippi, Luciana Cunha, Camila, Andrea, Adriana, Gabi, Aninha e Raissa pela excelente companhia que vocês me proporcionaram todo este tempo.

Aos meus amigos Aline Ameni, Beatriz Dorr, Sayuri, Thaisa Sandini e Thiago Marinho, vocês foram os irmãos que escolhi, um presente divino, amizade que iniciou na pós graduação e vai bem mais além disso. Obrigada por todo apoio científico, pela companhia e amizade fiel incondicional. Vocês fazem parte da minha vida e sempre farão. 


\section{RESUMO}

MACHADO, T. R. M. Alterações neuroimunes induzidas em camundongos machos pela convivência com um companheiro doente. [Neuroimmune alteractions induced in male mice by cohabitation with a sick cage mate]. 2013. 147 f. Dissertação (Mestrado em Ciências) - Faculdade de Medicina Veterinária e Zootecnia, Universidade de São Paulo, São Paulo, 2013.

Os trabalhos na área de neuroimumomodulação vêm contribuindo de forma marcante para o entendimento da regulação/modulação das respostas adaptativas dos organismos frente ao estresse ou às doenças. Sabe-se que o ato de um animal conviver com outro doente leva a alterações imunes e comportamentais, assim como acontece em humanos, nos caregivers. Nos animais foi comprovado que o odor liberado pelo outro doente é a fonte de estresse para todas essas alterações neuroimunes. Estudos em camundongos fêmeas mostraram uma diminuição de imunidade inata, alteração de comportamento; redução da atividade de neutrófilos e menor resistência ao crescimento de tumores em companheiros de animais doentes. O presente estudo teve como objetivo avaliar alterações neuroimunes em camundos machos que conviveram por 11 dias com um companheiro doente portador de um tumor ascítico de Ehrlich, e avaliar a participação do eixo Hipotálamo-Pituitária-Adrenal (HPA) e do Sistema Nervoso Autônomo Simpático (SNAS) no fenômeno observado. Os resultados obtidos mostraram que esta convivência: 1) não alterou os níveis séricos de corticosterona; 2) não modificou o peso relativo da glândula adrenal; 3) aumentou os níveis plasmáticos de adrenalina e noradrenalina; 4) diminuiu o burst oxidativo de neutrófilos induzido por PMA e por $S$. aureus, porém não modificou a porcentagem e a intensidade de fagocitose; 5) diminuiu a resistência ao crescimento de um tumor ascítico de Ehrlich; 6) aumentou os níveis de TNF$\alpha$, INF- $\gamma$ e IL-6 após 24 horas e de TNF- $\alpha$ e IL-6 após 48 horas de incubação de esplenócitos com LPS; 7) não modificou o comportamento avaliado no campo aberto; 8) aumentou o turnover de noradrenalina no córtex frontal, diminuiu os níveis de noradrenalina no bulbo olfatório, diminuiu os níveis de HVA, um metabólito da dopamina, no hipotálamo e no bulbo e aumentou os níveis de serotonina e seu metabólito 5HIAA no córtex frontal; 9) não modificou a expressão IL-1, IL-6 e TNF- $\alpha$ no hipotálamo e no córtex frontal. Em seu conjunto, os presentes resultados mostram que a convivência de camundongos machos com portadores de um tumor ascítico de Ehrlich, o que representa aqui um estresse prolongado, embora não tenha alterado o comportamento dos machos e a atividade do eixo HPA, modificou nestes animais a atividade do SNAS, reduzindo a imunidade inata dos animais. 
Conclui-se então, estar o SNAS envolvido com as alterações de imunidade inata desencadeadas em camundongos machos pela convivência com um companheiro doente.

Palavras-chave: Neuroimunomodulação. Imunidade inata. Estresse psicológico. Dimorfismo sexual. Tumor de Ehrlich. 


\begin{abstract}
MACHADO, T. R. M. Neuroimmune alteractions induced in male mice by cohabitation with a sick cage mate. [Alterações neuroimunes induzidas em camundongos machos pela convivência com um companheiro doente]. 2013. 147 f. Dissertação (Mestrado em Ciências) - Faculdade de Medicina Veterinária e Zootecnia, Universidade de São Paulo, São Paulo, 2013.
\end{abstract}

Studies in the neuroimmunomodulation area have markedly contributed to the understanding of the regulation / modulation of the organisms adaptive responses against stressors or diseases. Cohabitation with a sick cage mate leads to immune and behavioral changes, similar to those reported in humans, called caregivers. In animals, it was shown that the odor released by the tumor injected partner is pivotal for the stress response they presented and for all the neuroimmune changes reported that included: a decreased innate immunity, altered behavior such as increased levels of locomotion and decreased resistance to tumor growth. Following this line of research, the present study aimed to evaluate the possible neuroimmune changes presented by males mice that lived for 11 days with a sick cage mate, i.e., carrier of an Ehrlich ascitie tumor; a search for the pathways responsible for the observed effects was also an objective of the present work. Our results showed that cohabitation with a sick cage mate produced in male mice: 1) increased levels of plasmatic adrenaline and noradrenaline, 2) decreased neutrophil oxidative burst after PMA and S. aureus stimulatior, but no changes in the percentage and intensity of neutrophil phagocytosis, 3) decreased organic resistance to an Ehrlich tumor growth 4) increased levels of TNF- $\alpha$, INF- $\gamma$ and IL-6 24 hours after and TNF- $\alpha$ and IL-6 48 hours after splenocytes stimulation with LPS, 5) increased turnover of norepinephrine in the frontal cortex, decreased levels of norepinephrine in the olfactory bulb, reduced levels of HVA in the bulb and hypothalamus and increased levels of serotonin and its metabolite 5HIAA in the frontal cortex. Further analysis, showed no changes in: 6) serum corticosterone; 7) the relative weight of adrenal glands; 8) behavior assessed by open field, 9) IL-1, IL-6 and TNF- $\alpha$ expression in both hypothalamus and frontal cortex. Taken together our results, showed that cohabitation with a male sick cage mate taken here as a source of a prolonged stress induced in male mice a decrease in their innate immunity, most probably thought SANS stimulation and peripheral cytokine changes. As reported for female mice, the HPA axis was also not changed in male companion of tumor injected mice. Furthermore and importantly, our data showed some neuroimmune differences between male and female 
responses to the condition imposed, being the males less sensible than females. Differences in hormonal status and/or in the ethological predisposition and response of male and female mice the stress of living with a sick cage mate were discussed and taken as the possible causes for the observed discrepancies.

Keywords: Neuroimmunomodulation. Innate immunity. Psychological stress. Sexual dimorphism. Ehrlich tumor. 


\section{LISTA DE FIGURAS}

Figura 1- Esquema ilustrativo da interação entre o sistema nervoso, sistema imune e sistema endócrino

Figura 2- Inervações do Sistema Nervoso Autônomo nos respectivos órgãos

Figura 3- Esquema ilustrativo do grupo experimental utilizado nesta dissertação. O animal companheiro será o objeto experimental deste trabalho

Figura 4-Esquema ilustrativo da formação dos grupos experimentais deste trabalho

Figura 5- Citômetro de Fluxo modelo FACScalibur da Becton Dickinson acoplado a um computador Machintosh (G4) da Apple utilizado no presente trabalho para avaliar a atividade de neutrófilos

Figura 6- Representação esquemática da sequiência de reagentes utilizados nas técnicas de burst oxidativo e fagocitose

Figura 7- Esquema ilustrativo da formação dos grupos experimentais dos experimentos em que se avaliou o crescimento tumoral em camundongos machos companheiros

Figura 8- EthoVision ${ }^{\circledR}$-(Vídeo Tracking Motion \& Behavior Recognition System Versão 2.3)equipamento de rastreamento em vídeo, usado no procedimento experimental para análise de movimentos

Figura 9- (A) Citograma que ilustra as populações de nanobeads da curva padrão para as diferentes citocinas na concentração de $625 \mathrm{pg} / \mathrm{mL}$. (B) Histograma que ilustra os picos de intensidade de fluorescência para as diferentes populações de nanobeads.

Figura 10- Níveis séricos de corticosterona no $5^{\circ}$ dia de convivência com portadores de umtumor ascítico de Ehrlich

Figura 11- Níveis séricos de corticosterona no $7^{\circ}$ dia de convivência com portadores de um tumor ascítico de Ehrlich

Figura 12- Níveis séricos de corticosterona no $9^{\circ}$ dia de convivência com portadores de um tumor ascítico de Ehrlich

Figura 13- Níveis séricos de corticosterona no $11^{\circ}$ dia de convivência com portadores de um tumor ascítico de Ehrlich.

Figura 14- Níveis séricos de corticosterona expressos em porcentagem (\%) no $5^{\circ}$ dia de convivência com portadores de um tumor ascítico de Ehrlich

Figura 15- Níveis séricos de corticosterona expressos em porcentagem (\%) no $7^{\circ}$ dia de convivência com portadores de um tumor ascítico de Ehrlich

Figura 16- Níveis séricos de corticosterona expressos em porcentagem (\%) no $9^{\circ}$ dia de convivência com portadores de um tumor ascítico de Ehrlich

Figura 17- Níveis séricos de corticosterona expressos em porcentagem (\%) no $11^{\circ}$ dia de convivência com portadores de um tumor ascítico de Ehrlich 
Figura 18- Níveis séricos de corticosterona correlacionando os grupos e dias de convivência em $\mathrm{pg} / \mathrm{ml}$ no $5^{\circ}, 7^{\circ}, 9^{\circ}$ e $11^{\circ}$ dias de convivência com portadores de um tumor ascítico de Ehrlich.

Figura 19- Efeitos sobre o peso relativo da glândula adrenal no $11^{\circ}$ dia de convivência com portadores de um tumor ascítico de Ehrlich.....

Figura 20- Efeitos sobre o nível de adrenalina plasmática no $11^{\circ}$ dia de convivência com portadores de um tumor ascítico de Ehrlich.

Figura 21- Efeitos sobre o nível de noradrenalina plasmática no $11^{\circ}$ dia de convivência com portadores de um tumor ascítico de Ehrlich....

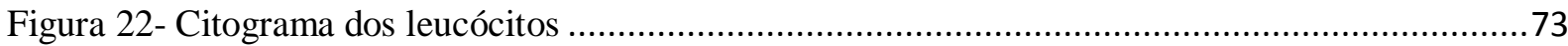

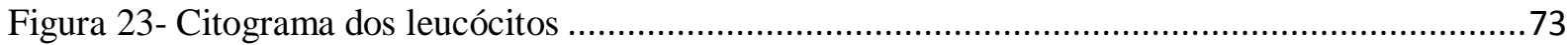

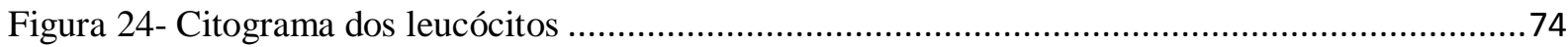

Figura 25- Citogramas de leucócitos circulantes de camundongos incubados com PBS......................74

Figura 26- Histograma de neutrófilos de animais do grupo controle incubado com S. aureus realizando fagocitose

Figura 27- Efeitos da convivência com portadores de um tumor ascítico de Ehrlich, por 11 dias sobre o burst oxidativo basal de neutrófilos.

Figura 28- Efeitos da convivência com portadores de um tumor ascítico de Ehrlich, por 11 dias sobre o burstoxidativo de neutrófilos induzido por PMA

Figura 29- Efeitos da convivência com portadores de um tumor ascítico de Ehrlich, por 11 dias sobre o burstoxidativo de neutrófilos induzido por S. aureus

Figura 30- Efeitos da convivência com portadores de um tumor ascítico de Ehrlich, por 11 dias sobre o burstoxidativo de neutrófilos induzido por PMA expresso em porcentagem

Figura 31- Efeitos da convivência com portadores de um tumor ascítico de Ehrlich, por 11 dias sobre o burst oxidativo de neutrófilos induzido por $S$. aureus expresso em porcentagem ..78

Figura 32- Efeitos da convivência com portadores de um tumor ascítico de Ehrlich, por 11 dias sobre a intensidade de fagocitose de neutrófilos

Figura 33- Efeitos da convivência com portadores de um tumor ascítico de Ehrlich, por 11 dias sobre a porcentagem de fagocitose de neutrófilos

Figura 34- Efeitos da convivência por 11 dias com portadores do tumor ascítico de Ehrlich sobre aconcentração de células tumorais/ml (x107) de camundongos inoculados com o mesmo tumor ( 5 x 106células)

Figura 35- Efeitos da convivência por 11 dias com portadores do tumor ascítico de Ehrlich sobre o número de células tumorais totais (x107) de camundongos inoculados com o mesmo tumor ( 5 x 106células) 
Figura 36- Efeitos da convivência por 11 dias com portadores do tumor ascítico de Ehrlich sobre o volume de líquido ascítico em $\mathrm{ml}$ de camundongos inoculados com o mesmo tumor $(5 \mathrm{x}$ $10^{6}$ células)

Figura 37- Efeitos da convivência por 11 dias com portadores do tumor ascítico de Ehrlich sobre a distância total em centímetros percorrida no campo aberto

Figura 38-Efeitos da convivência por 11 dias com portadores do tumor ascítico de Ehrlich sobre o tempo em segundos de permanência na zona periférica do campo aberto

Figura 39- Efeitos da convivência por 11 dias com portadores do tumor ascítico de Ehrlich sobre o número de entradas na zona periférica do campo aberto

Figura 40- Efeitos da convivência por 11 dias com portadores do tumor ascítico de Ehrlich sobre o tempo em segundos de permanência na zona central do campo aberto

Figura 41- Efeitos da convivência por 11 dias com portadores do tumor ascítico de Ehrlich sobreo número de entradas na zona central do campo aberto

Figura 42- Efeitos da convivência por 11 dias com portadores do tumor ascítico de Ehrlich sobre o tempo em segundos de imobilidade no campo aberto

Figura 43- Efeitos da convivência por 11 dias com portadores do tumor ascítico de Ehrlich sobre o número de início de movimentos no campo aberto

Figura 44- Efeitos da convivência por 11 dias com portadores do tumor ascítico de Ehrlich sobre o tempo em segundos de movimento no campo aberto.....

Figura 45- Efeitos da convivência por 11 dias com portadores do tumor ascítico de Ehrlich sobre a velocidade média em $\mathrm{cm} / \mathrm{sg}$ percorrida no campo aberto

Figura 46- Efeitos da convivência por 11 dias com portadores de um tumor ascítico de Ehrlich, sobre os níveis de Noradrenalina no Hipotálamo e Córtex Frontal

Figura 47- Efeitos da convivência por 11 dias com portadores de um tumor ascítico de Ehrlich, sobre os níveis de Noradrenalina no Bulbo

Figura 48- Efeitos da convivência por 11 dias com portadores de um tumor ascítico de Ehrlich, sobre os níveis do metabólito da Noradrenalina VMA no Córtex Frontal.

Figura 49- Efeitos da convivência por 11 dias com portadores de um tumor ascítico de Ehrlich, sobre os níveis do metabólito da Noradrenalina VMA no Bulbo.

Figura 50- Efeitos da convivência por 11 dias com portadores de um tumor ascítico de Ehrlich, sobre o "turnover" da Noradrenalina no Córtex Frontal.....

Figura 51- Efeitos da convivência por 11 dias com portadores de um tumor ascítico de Ehrlich, sobre o "turnover" da Noradrenalina no Bulbo.....

Figura 52- Efeitos da convivência por 11 dias com portadores de um tumor ascítico de Ehrlich, sobre os níveis de Dopamina no Hipotálamo, Córtex Frontal e Bulbo.....

Figura 53- Efeitos da convivência por 11 dias com portadores de um tumor ascítico de Ehrlich, sobre os níveis do metabólito da Dopamina HVA no Hipotálamo e Bulbo..... 
Figura 54- Efeitos da convivência por 11 dias com portadores de um tumor ascítico de Ehrlich, sobre os níveis do metabólito da Dopamina HVA no Córtex Frontal

Figura 55- Efeitos da convivência por 11 dias com portadores de um tumor ascítico de Ehrlich, sobre os níveis do metabólito da Dopamina DOPAC no Hipotálamo, Córtex Frontal e Bulbo

Figura 56- Efeitos da convivência por 11 dias com portadores de um tumor ascítico de Ehrlich, sobre o "turnover" da Dopamina no Hipotálamo, Córtex Frontal e Bulbo

Figura 57- Efeitos da convivência por 11 dias com portadores de um tumor ascítico de Ehrlich, sobre o "turnover" da Dopamina no Hipotálamo, Córtex Frontal e Bulbo

Figura 58- Efeitos da convivência por 11 dias com portadores de um tumor ascítico de Ehrlich, sobre o "turnover" da Dopamina no Hipotálamo, Córtex Frontal e Bulbo . .95

Figura 59- Efeitos da convivência por 11 dias com portadores de um tumor ascítico de Ehrlich, sobre os níveis de Serotonina no Hipotálamo e Bulbo

Figura 60- Efeitos da convivência por 11 dias com portadores de um tumor ascítico de Ehrlich, sobre os níveis de Serotonina no Córtex Frontal

Figura 61- Efeitos da convivência por 11 dias com portadores de um tumor ascítico de Ehrlich, sobre os níveis do metabólito da Serotonina 5HIAA no Hipotálamo e Bulbo

Figura 62- Efeitos da convivência por 11 dias com portadores de um tumor ascítico de Ehrlich, sobre os níveis do metabólito da Serotonina 5HIAA no Córtex Frontal

Figura 63- Efeitos da convivência por 11 dias com portadores de um tumor ascítico de Ehrlich, sobre o "turnover" da Serotonina no Hipotálamo, Córtex Frontal e Bulbo

Figura 64- Efeitos da convivência por 11 dias com portadores do tumor ascítico de Ehrlich sobre os níveis de TNF- $\alpha 24$ horas após incubação com estímulo LPS dosada por CBA

Figura 65- Efeitos da convivência por 11 dias com portadores do tumor ascítico de Ehrlich sobre os níveis de IFN- $\gamma 24$ horas após incubação com estímulo LPS dosada por CBA

Figura 66- Efeitos da convivência por 11 dias com portadores do tumor ascítico de Ehrlich sobre os níveis de IL-6 24 horas após incubação com estímulo LPS dosada por CBA

Figura 67- Efeitos da convivência por 11 dias com portadores do tumor ascítico de Ehrlich sobre os níveis de TNF- $\alpha 48$ horas após incubação com estímulo LPS dosada por CBA

Figura 68- Efeitos da convivência por 11 dias com portadores do tumor ascítico de Ehrlich sobre os níveis de IL-6 48 horas após incubação com estímulo LPS dosada por CBA ...............101

Figura 69- Efeitos da convivência por 11 dias com portadores do tumor ascítico de Ehrlich sobre os níveis de IFN- $\gamma 48$ horas após incubação com estímulo LPS dosada por CBA.

Figura 70- Efeitos da convivência por 11 dias com portadores do tumor ascítico de Ehrlich sobre os níveis de IL-10 48 horas após incubação com estímulo LPS dosada por CBA

Figura 71- Efeitos da convivência por 11 dias com portadores do tumor ascítico de Ehrlich sobre a expressão relativa de TNF- $\alpha$ no Hipotálamo. 
Figura 72- Efeitos da convivência por 11 dias com portadores do tumor ascítico de Ehrlich sobre a expressão relativa de IL-1 no Hipotálamo

Figura 73- Efeitos da convivência por 11 dias com portadores do tumor ascítico de Ehrlich sobre a expressão relativa de IL-6 no Hipotálamo .104

Figura 74- Efeitos da convivência por 11 dias com portadores do tumor ascítico de Ehrlich sobre a expressão relativa de IL-1 no Córtex .105

Figura 75- Efeitos da convivência por 11 dias com portadores do tumor ascítico de Ehrlich sobre a expressão relativa de IL-6 no Córtex 105

Figura 76- Efeitos da convivência por 11 dias com portadores do tumor ascítico de Ehrlich sobre a expressão relativa de TNF- $\alpha$ no Córtex 106 


\section{LISTA DE TABELAS}

Tabela 1- Limites de detecção das citocinas em pg/ml

Tabela 2- Efeitos da convivência por 11 dias com portadores de um tumor de Ehrlich, sobre o burstoxidativo e sobre a fagocitose de neutrófilos medidos por Citometria de Fluxo

Tabela 3- Efeitos da convivência por 11 dias com portadores de um tumor ascítico de Ehrlich sobre o volume $(\mathrm{ml})$, concentração e número total de células após inoculação do tumor ascítico de Ehrlich (5x10 $0^{6}$ células tumorais/animal)

Tabela 4- Efeitos da convivência por 11 dias com portadores de um tumor ascético de Ehrlich, sobre os níveis e "turnover" hipotalâmicos, corticais e bulbar de noradrenalina, dopamina, serotonina e seus metabólitos 


\section{LISTA DE ABREVIATURAS}

5HIAA- Ácido 5-hidroindol, 3-acético

5-HT- Serotonina

ACTH- Hormônio adrenocorticotrópico

ADR- Adrenalina

CAD- Companheiro do animal doente

CAS- Companheiro do animal doente

CRF- Fator liberador de corticotrofina

CRH- Hormônio liberador de corticotrofina

DA- Dopamina

DBH- Dopamina-beta-hidroxilase

DCFH- DA- 2'7' diacetato de diclorofluoresceína

DHBA- 3,4 diidroxibenzilamina

DOPAC- Ácido 4,4-diidroxifenilacético

GC- Glicocorticóides

HPA- Eixo Hipotálamo- Pituitária- Adrenal

HPLC- Cromatografia Líquida de Alta Eficiência

HVA- Ácido homovanílico

IFN- Interferon

Ig- Imunoglobulina

IL- Interleucina

LPS- Lipopolissacarídeo

NK- Célula Natural Killer

NOR- Noradrenalina

OVA- Ovalbumina

PBS- Phosphate Buffered Saline

PI- Iodeto de Propídeo

PMA- Miristato acetato de forbol

SI- Sistema Imune

SN- Sistema Nervoso

SNAP- Sistema Nervoso Autônomo Parassimpático

SNAS- Sistema Nervoso Autônomo Simpático

SNC- Sistema Nervoso Central

Th1- Linfócitos T helper 1 
Th2- Linfócitos T helper 2

TNF- Fator de Necrose Tumoral

VMA- Ácido vanilmandélico

$\beta_{2}$ AR- Receptores $\beta_{2}$ adrenérgicos 


\section{SUMÁRIO}

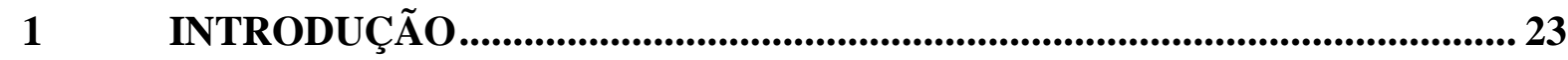

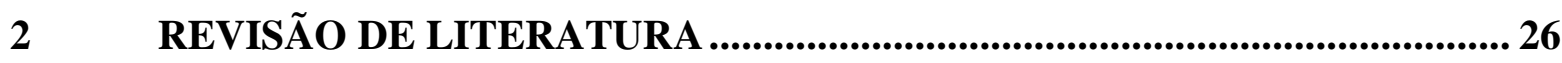

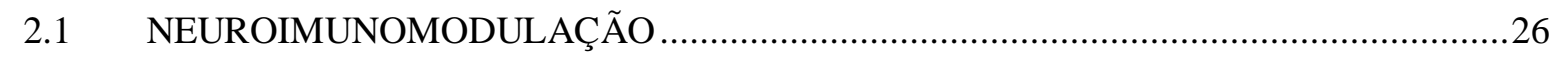

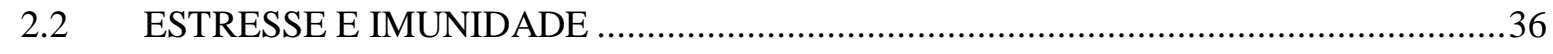

2.3 A CONVIVÊNCIA COM ANIMAIS DOENTES ………………………………….......39

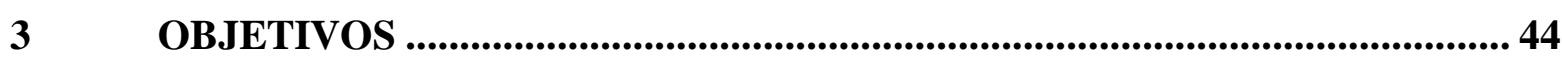

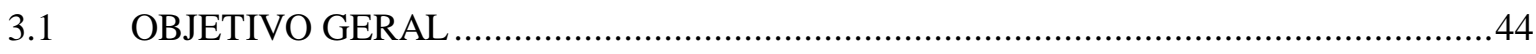

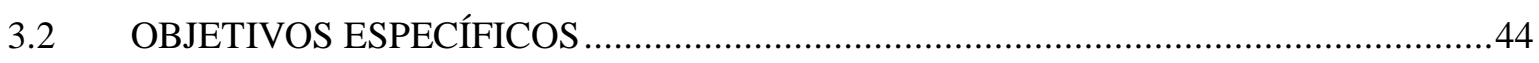

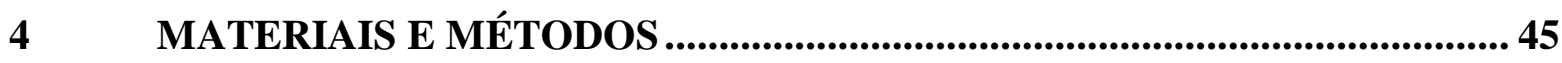

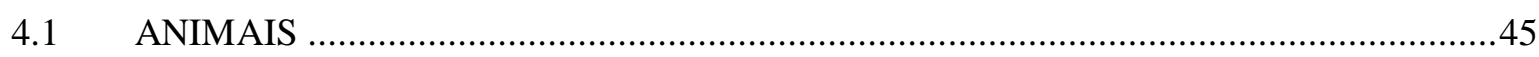

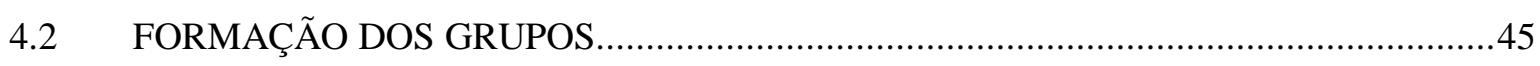

4.3 OBTENÇÃO E MANUTENÇÃO DO TUMOR ASCÍTICO DE EHRLICH ......................46

4.4 DOSAGEM DE CORTICOSTERONA SÉRICA NO $5^{\circ}, 7^{\circ}, 9^{\circ}$ E $11^{\circ}$ DIAS DE CONVIVÊNCIA COM O DOENTE POR ELISA...........................................................47

4.5 PESO DA GLÂNDULA ADRENAL ..........................................................................4

4.6 DOSAGEM DE ADRENALINA E NORADRENALINA PLASMÁTICOS NO $11^{\circ}$ DIA DE CONVIVÊNCIA COM O DOENTE POR ELISA.................................................48

4.7 BURST OXIDATIVO E FAGOCITOSE DE NEUTRÓFILOS POR CITOMETRIA DE

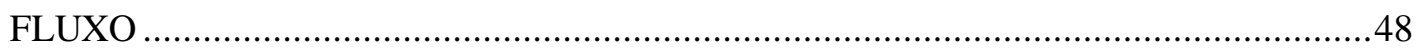

4.8 AVALIAÇÃO DO CRESCIMENTO DO TUMOR DE EHRLICH ………………….......52

4.9 COMPORTAMENTO EM CAMPO ABERTO...........................................................53

4.10 DOSAGENS NEUROQUÍMICAS ……………………………………………....56

4.11 NÍVES DE CITOCINAS (IFN- $\gamma$, IL-12, IL-10, IL-6 E TNF- $\alpha$ ) NO BAÇO NO $11^{\circ}$ DIA DE CONVIVÊNCIA COM O DOENTE.....................................................................57

4.12 ANÁLISE DE EXPRESSÃO GÊNICA DE CITOCINAS (IL-1B, IL-6 E TNF- $\alpha$ ) NO HIPOTÁLAMO E CÓRTEX FRONTAL NO $11^{\circ}$ DIA DE CONVIVÊNCIA COM O DOENTE..

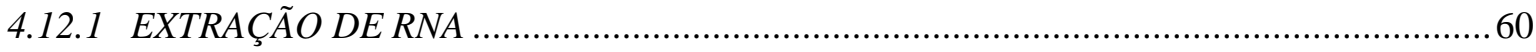

4.12.2 QUANTIFICAÇÃO E DETERMINAÇÃO DA INTEGRIDADE DO RNA TOTAL...............60

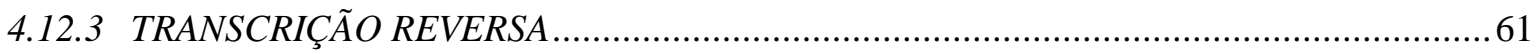

4.12.4 QUANTIFICAÇÃO DA EXPRESSÃO GÊNICA POR PCR EM TEMPO REAL..................61

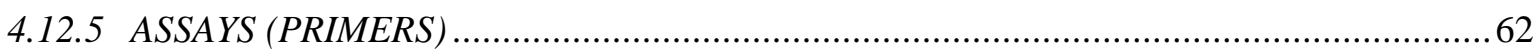

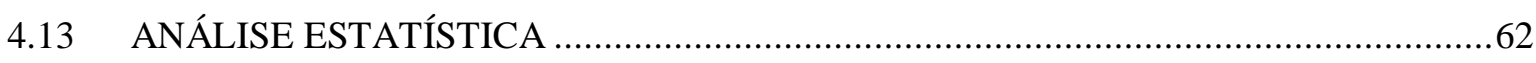

5 DELINEAMENTO EXPERIMENTAL E RESULTADOS ............................... 63 
5.1 EXPERIMENTO 1- AVALIAÇÃO DOS NÍVEIS DE CORTICOSTERONA SÉRICA NO $5^{\circ}, 7^{\circ}, 9^{\circ} \mathrm{E} 11^{\circ}$ DIA DE CONVIVÊNCIA COM O DOENTE POR ELISA

5.2 EXPERIMENTO 2- AVALIAÇÃO DO PESO RELATIVO DA GLÂNDULA ADRENAL.

5.3 EXPERIMENTO 3- AVALIAÇÃO DOS NÍVEIS PLASMÁTICOS DE ADRENALINA E NORADRENALINA NO $11^{\circ}$ DIA DE CONVIVÊNCIA COM O DOENTE POR ELISA

5.4 EXPERIMENTO 4- AVALIAÇÃO DO BURST OXIDATIVO E FAGOCITOSE DE NEUTRÓFILOS NO $11^{\circ}$ DIA DE CONVIVÊNCIA COM O DOENTEPOR CITOMETRIA DE FLUXO.

5.5 EXPERIMENTO 5- AVALIAÇÃO DO CRESCIMENTO DE UM TUMOR ASCÍTICO DE EHRLICH NO $11^{\circ}$ DIA DE CONVIVÊNCIA COM O DOENTE

5.6 EXPERIMENTO 6- MEDIDA DE ATIVIDADE GERAL DOS ANIMAIS NO $11^{\circ}$ DIA DE CONVIVÊNCIA COM O DOENTE NO CAMPO ABERTO.

5.7 EXPERIMENTO 7- DOSAGEM DE MONOAMINAS E DE SEUS METABÓLITOS NO HIPOTÁlAMO, BULBO E CÓRTEX FRONTAL NO $11^{\circ}$ DIA DE CONVIVÊNCIA COM O DOENTE

5.8 EXPERIMENTO 8- EXPRESSÃO DE CITOCINAS (IFN- $\gamma$, IL-12, IL-10, IL-6 E TNF- $\alpha$ ) NO BAÇO NO $11^{\circ}$ DIA DE CONVIVÊNCIA COM O DOENTE

5.9 EXPERIMENTO 9- EXPRESSÃO DE CITOCINAS (IL-1B, IL-6 E TNF- $\alpha$ ) NO HIPOTÁLAMO E CÓRTEX FRONTAL NO $11^{\circ}$ DIA DE CONVIVÊNCIA COM O DOENTE

6 DISCUSSÃO 107

7 126

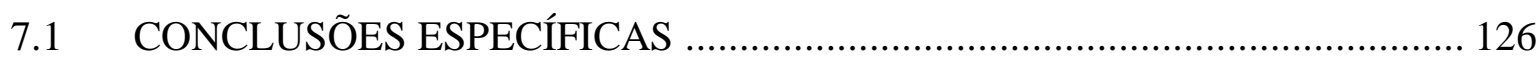

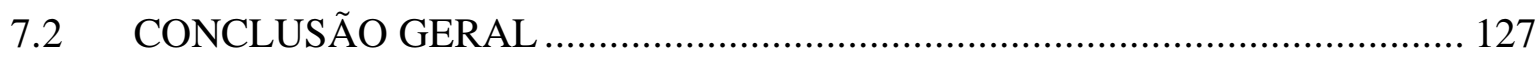

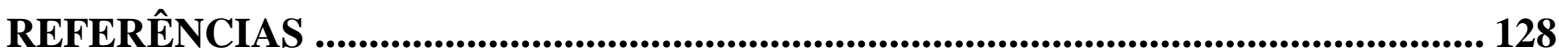




\section{INTRODUÇÃO}

A neuroimunomodulação foi conceituada como a área de estudo que avaliava as influências mutuas entre os sistemas nervoso e imune (REICHLIN, 1993). Os trabalhos nesta área vêm contribuindo de forma marcante para o entendimento da regulação/modulação das respostas adaptativas dos organismos frente ao estresse e das modificações neurofisiológicas e comportamentais induzidas, por exemplo, por citocinas. Estes estudos têm justificando a idéia, agora inequívoca, de que existem extensas relações bidirecionais entre os sistemas nervoso e imune (ADER, 2000).

A ativação do eixo HPA, e a consequente produção dos glicocorticóides, durante o estresse modula a resposta imune. Sabe-se serem os glicocorticóides capazes de inibir a transcrição de inúmeras citocinas, como de interleucina - 1 (IL-1), IL-13, IL-5, IL-6, IL-8, fator de necrose tumoral (TNF- $\alpha$ ) e fator estimulante de colônia (GM-CSF) (GUYRE et al., 1988). Além disso, os glicocorticóides interferem não apenas com a síntese de citocinas mas diminuem, também, a migração/quimiotaxia de eosinófilos (SUGIMOTO et al., 2003) e de neutrófilos (VAN OVERVELD et al., 2003).

Além do eixo HPA, outro importante mecanismo ativado durante o estresse está ligado ao Sistema Nervoso Autônomo Simpático (SNAS); a estimulação deste sistema leva à liberação de noradrenalina (NOR) nos terminais nervosos simpáticos e à secreção de adrenalina pela adrenal (MAIER, 2003). Sabe-se que as fibras simpáticas terminam em íntimo contato com os órgãos linfóides como acontece, por exemplo, no baço que apresenta intensa inervação simpática (MADDEN; FELTEN, 1995). Aparentemente, todos os leucócitos expressam receptores $\beta$-adrenérgicos $\left(\beta_{2} \mathrm{AR}\right)$, com exceção apenas dos clones de linfócitos auxiliares (T CD4+) do tipo Th2 (KOHM; SANDERS, 1999; MADDEN, 2003).

Neste contexto, sabe-se que o estresse gerado pelo ato de acompanhar pacientes com enfermidades crônicas tem sido associado em humanos a alterações de imunidade inata e humoral, queda de resistência orgânica a infecções e aparecimento de sintomas psiquiátricos, como ansiedade e depressão (ALVES et al., 2006; ALVES; PALERMO-NETO, 2007; ALVES; VISMARI; PALERMO-NETO, 2007; ALPI et al., 2008; FREDMAN et al., 2010; JIWA et al., 2010). Analisando em nossos laboratórios parâmetros comportamentais e imunes de camundongas que conviveram com companheiras doentes (portadores de um tumor de Ehrlich) por 11 dias, observamos o aparecimento de leucopenia nestes animais e, apesar da 
presença de níveis normais de corticosterona, eles mostraram-se mais suscetíveis ao desenvolvimento do mesmo tumor experimental (MORGULIS et al., 2004).

Alves et al.(2006) mostraram também, que camundongas que coabitaram por 11 dias com conspecíficas doentes apresentavam aumento de atividade motora no campo aberto. A convivência com um animal doente induziu também (a) uma diminuição nos níveis e um aumento no turnover hipotalâmico de noradrenalina (NOR); (b) uma diminuição no burst oxidativo de neutrófilos após indução com miristato acetato de forbol (PMA) ou Staphylococcus aureus; (c) uma diminuição na porcentagem e na intensidade de fagocitose de neutrófilos (ALVES et al., 2006). A fagocitose de macrófagos peritoneais também foi menor nas camundongas que conviveram com conspecíficas doentes em relação ao grupo controle, ou seja, animais que haviam convivido com companheiras saudáveis (ALVES; VISMARI; PALERMO-NETO, 2007).

De relevância, observaram também em camundongas que conviveram com portadoras de um tumor por 14 dias uma redução do peso e da celularidade do baço, redução da porcentagem de linfócitos B e T helper e na proporção CD4/CD8 no baço, aumento do tempo de permanência com um animal estranho e redução deste tempo de permanência junto à companheira doente em um labirinto em $\mathrm{T}$, uma redução do burst oxidativo basal de neutrófilos provenientes de animais que conviveram com dois doentes, níveis de adrenalina e noradrenalina plasmáticas aumentados. No entanto e, muito relevante, observaram que estímulos olfativos provenientes do doente eram fundamentais para a manifestação das alterações induzidas pela convivência sobre o burst oxidativo e fagocitose de neutrófilos, crescimento tumoral, alterações comportamentais, níveis plasmáticos de noradrenalina e adrenalina, níveis hipotalâmicos de noradrenalina (ALVES et al., 2010; ALVES; RIBEIRO; PALERMO-NETO, 2012).

Em vista de tudo quanto exposto, propõe-se estudar no presente projeto se as principais alterações neuroimunes que ocorrem em fêmeas que conviveram por 11 dias com uma companheira portadora do tumor ascítico de Ehrlich como relatado por Alves, 2006 acontecem também em machos. O tumor ascítico de Ehrlich foi escolhido como ferramenta para este trabalho por ser ele facilmente induzido e mensurado em camundongos e, também por elicitar uma forte resposta imune. Estas propriedades têm feito deste tumor um interessante modelo de análise dos efeitos de fármacos ou de alterações em eventos externos, como por exemplo, do estresse, como observado em trabalhos do nosso grupo citados acima. Em sequiência, pretende-se analisar os níveis de adrenalina e noradrenalina plasmáticos, a expressão de interleucinas IL-1 $\beta$, IL-6 e TNF- $\alpha$ no hipotálamo e no córtex, bem como a 
expressão de citocinas (IFN- $\gamma$, IL-12, IL-10, IL-6 e TNF- $\alpha$ ) no baço e, finalmente, o peso relativo da glândula adrenal nos machos que conviveram com o companheiro doente. 


\section{REVISÃO DE LITERATURA}

\subsection{NEUROIMUNOMODULAÇÃO}

A neuroimunomodulação ou psiconeuroimunologia foi conceituada como a área de estudo que avalia as influências mutuas entre os sistemas nervoso ( $\mathrm{SN}$ ) e imune (SI) (REICHLIN, 1993); de fato, evidências convergentes dos campos da psicologia, neurobiologia e imunologia vêmdemonstrando que o sistema imune não é regulado de maneira exclusivamente autônoma, mas que é influenciado por fatores externos direcionados pelo sistema nervoso central (SNC) (MADDEN; FELTEN, 1995). Porém, foi somente nas duas últimas décadas que a neuroimunomodulação ganhou maior importância, e fôros de ciência visto que, até então, prevalecia uma tendência de setorialização das abordagens experimentais que se faziam nos SI e SNC (CONTI, 2000). No entanto, lembra-se que Galeno, em 200 a.C., já descrevia serem mulheres "melancólicas" mais suscetíveis ao desenvolvimento de neoplasias mamárias que mulheres "sanguíneas" (DUNN, E.; BROWN; LOVE, 1995); caracterizando que a neuroimunomodulação vem sendo estudada há muitos anos, mesmo que de maneira informal.

Os trabalhos nesta área vêm contribuindo de forma marcante para o entendimento da regulação/modulação das respostas adaptativas dos organismos frente ao estresse e das modificações neurofisiológicas e comportamentais induzidas, por exemplo, por citocinas, justificando a idéia, agora inequívoca, de que existem extensas relações bidirecionais entre os sistemas nervoso e imune (ADER, 2000). Atualmente sabe-se que diversos estímulos provenientes do SNC, como lesões no córtex cerebral, estresse e variações psicológicas, são capazes de modular uma resposta imune. Dessa forma, estados de ansiedade e depressão, levam a um déficit pronunciado na imunidade, em especial, do número de células esplênicas, da proliferação de linfócitos $\mathrm{B}, \mathrm{T}$, T helper e $\mathrm{T}$ citotóxico, da atividade e do número de células Natural Killer (NK) e da atividade de macrófagos (PALERMO NETO; MASSOCO; FAVARE, 2001; FONSECA; MASSOCO; PALERMO-NETO, 2002; PALERMO-NETO; DE OLIVEIRA MASSOCO; ROBESPIERRE DE SOUZA, 2003; ALVES et al., 2006). Estas mesmas condições alteram a resposta imune interferindo com o crescimento neoplásico e com o desenvolvimento de infecções em animais (PALERMO NETO; MASSOCO; FAVARE, 
2001; PALERMO-NETO; DE OLIVEIRA MASSOCO; ROBESPIERRE DE SOUZA, 2003; SAKAI et al., 2006a; SAKAI et al., 2006b).

De todos os sistemas orgânicos apenas os sistemas nervoso e imune são capazes de fazer escolhas. O sistema imune de cada indivíduo registra uma história única de individualidade porque ele assim como o cérebro se organiza e se reorganiza constantemente através da experiência, das escolhas que faz (COSTA-PINTO et al., 2009). Nesse sentido, é relevante ter em mente, que a existência de um sistema cognitivo nervoso-imune possibilita a sobrevivência dos indivíduos ao permitir a eles a realização de escolhas, a construção de imagens internas e externas do ambiente e a auto-organização (COSTA-PINTO; PALERMONETO, 2010).

Um dos pioneiros no desenvolvimento da psiconeuroimunologia foi George Solomon. Foi ele quem iniciou a pesquisa clinica nesta área examinando a história de vida e as características de personalidade de seus pacientes relacionando-as com doenças autoimunes. $\mathrm{O}$ mais conhecido de seus estudos refere-se à análise que fez de pacientes com artrite reumatóide e do risco desta doença para os parentes dos mesmos; analisou, em especial, a presença ou ausência nestas pessoas de um fator reumatóide, um anticorpo anti IgG característico da artrite reumatóide. Observou que embora alguns dos parentes dos indivíduos acometidos pela doença autoimune se apresentassem positivos para o fator reumatóide, não desenvolviam a doença. Curiosamente esses pacientes apresentavam níveis baixo de ansiedade e depressão e desenvolviam uma boa relação com a esposa, familiares e amigos. Convencido da necessidade de confirmar esses dados e de realizar pesquisas nesta área Solomon fundou um laboratório de "psiconeuroimunologia", para analisar mais detalhadamente a influência de efeitos comportamentais, sociais e endócrinos sobre a função imune; avaliou principalmente a resposta orgânica a antígenos bacterianos, e à inoculação de tumores tendo verificado a existência de correlações positivas entre as variáveis estudadas (SOLOMON; AMKRAUT, 1981).

Podemos citar algumas formas de interação entre o SNC e o sistema imune como: o sistema endócrino, em especial o eixo Hipotálamo Pituitária Adrenal (HPA) (COHEN, S.; HERBERT, 1996; CONTI, 2000; ADER; KELLEY, 2007) e o Sistema Nervoso Autônomo Simpático (SNAS). O eixo HPA, atua através de hormônios hipotalâmicos e pituitários, como hormônio liberador de corticotrofina $(\mathrm{CRH})$, hormônio adrenocorticotrófico (ACTH), e glicocorticóides (GC); tireotrofinas, prostaglandinas, hormônio do crescimento e prolactina (ALVES; PALERMO-NETO, 2007). O SNAS, por sua vez, através das inervações simpáticas e parassimpáticas dos órgãos linfóides e da presença de receptores específicos em células 
imunes (BLALOCK, 1994; WRONA, 2006). Neste sentido, mostrou-se que fármacos que atuam no SNC como picrotoxina (STANKEVICIUS et al., 2008), diazepam (LAZZARINI; MALUCELLI; PALERMO-NETO, 2001; LAZZARINI et al., 2006; SAKAI et al., 2006), endocanabinóides (RIBEIRO et al., 2009; RIBEIRO et al., 2010), haloperidol (LOURENCO; DORCE; PALERMO-NETO, 2005); psicoestimulantes, entre eles a anfetamina (LIGEIROOLIVEIRA et al., 2004; LIGEIRO DE OLIVEIRA et al., 2008; DE OLIVEIRA et al., 2011) e o MDMA (DE PAULA et al., 2009; FERRAZ-DE-PAULA et al., 2011) também modifica a atividade imune, assim como o fazem estímulos estressores como por exemplo choque nas patas (FONSECA; MASSOCO; PALERMO-NETO, 2002), convivência com companheiro doente (ALVES et al., 2006; ALVES; VISMARI; PALERMO-NETO, 2007; PALERMONETO et al., 2008), restrição de movimento (CAO; HUDSON; LAWRENCE, 2003) e confronto sociais (SA-ROCHA; SA-ROCHA; PALERMO-NETO, 2006). A figura 1 ilustra a ação do Sistema Nervoso Central no Sistema Imune.

Figura 1- Esquema ilustrativo da interação entre o sistema nervoso, sistema imune e sistema endócrino

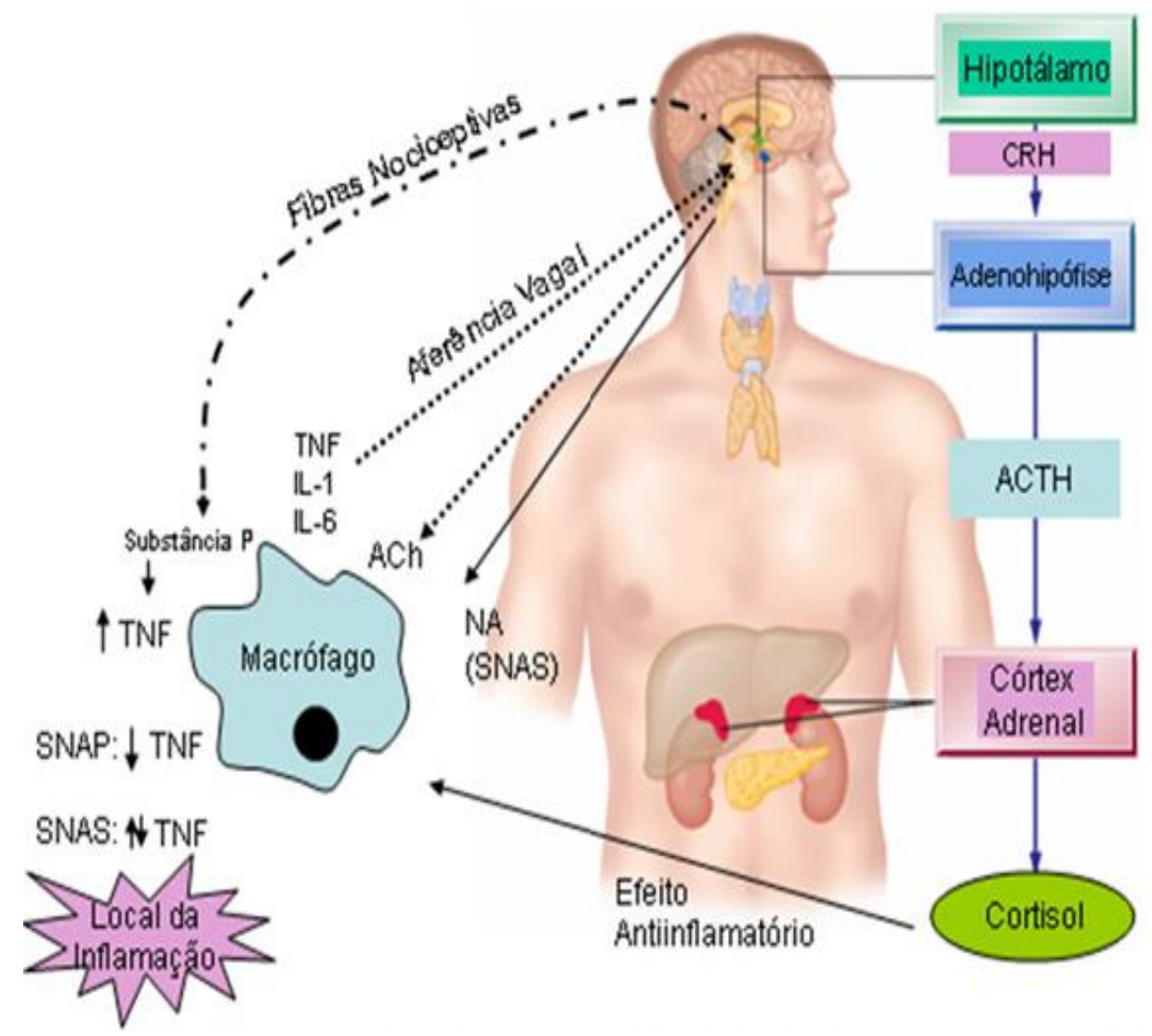

Fonte: http://www.sistemanervoso.com/pagina.php?secao=3\&materia_id=551\&materiaver=1\&imprimir=1 
Sabe-se serem os glicocorticóides capazes de inibir a transcrição de genes para inúmeras citocinas, como aqueles para interleucina (IL) 1, IL-6, IL-8, IL-11, IL-12, IL-13, IL16, fator de necrose tumoral (TNF- $\alpha$ ), interferon $\gamma$ (IFN- $\gamma$ ) (ADER; KELLEY, 2007) e fator estimulante de colônia (GM-CSF) (GUYRE et al., 1988). Além disso, interferem negativamente com o desenvolvimento e migração de células $\mathrm{T}$ através de uma inibição da expressão de moléculas de adesão (SCHONEVELD, 2007); diminuem receptores para IL-4 (SO et al., 2002); diminuem a atividade de macrófagos (MASSOCO; PALERMO-NETO, 2003) e de neutrófilos (ALVES et al., 2006) e diminuem, também, a migração/quimiotaxia de eosinófilos (SUGIMOTO et al., 2003). Talvez por isso uma análise de vários trabalhos que avaliaram a relação entre o estresse e parâmetros imunológicos tenha concluído estar o estresse, positivamente correlacionado ao aparecimento, em humanos, de leucocitose, diminuição no número de células $\mathrm{NK}$ e de linfócitos $\mathrm{T}$, aumento na relação de células CD4+/CD8+ e moderada diminuição nas atividades de células T e NK (ZORRILLA et al., 2001).

Desta forma, Zhou et al. (1993) mostraram que ratos submetidos a situações estressantes, como, por exemplo, choque nas patas, apresentaram um aumento dos níveis plasmáticos de ACTH, corticosterona e IL-6. Estes mesmos autores mostraram a importância dos hormônios para este fato, em especial dos glicocorticóides, pois ratos adrenalectomizados e submetidos à situação de estresse, apresentaram uma menor resposta ao estressor, mensurada pelo menor aumento dos níveis plasmáticos de IL-6 (ZHOU et al., 1993). Neste sentido, Cao e Lawrence mostraram que camundongos submetidos a um estresse agudo por frio e contenção apresentavam aumento dos níveis séricos de corticosterona, IL-6 e Interferon- $\gamma$ (IFN- $\gamma$ ), e também, um maior número de bactérias (Listeria monocytogenes) viáveis em órgãos como baço e fígado após uma infecção experimental, evidenciando, desta forma, a importância do estresse na modulação dos processos imunológicos e no desenvolvimento de uma infecção (CAO; LAWRENCE, 2002).

Em nosso grupo, Ligeiro-Oliveira e colaboradores mostraram que ratos sensibilizados com OVA (ovalbumina), uma proteína obtida da clara do ovo, e tratados com anfetamina apresentaram uma diminuição na população de leucócitos no pulmão e no sangue periférico e um aumento no número de células na medula óssea, em decorrência de uma ativação do eixo HPA com conseqüente liberação de corticosterona (LIGEIRO-OLIVEIRA et al., 2004). De fato, o pré tratamento dos animais sensibilizados com metirapona, um fármaco inibidor da síntese de corticosterona, reverteu parcialmente os efeitos induzidos pela anfetamina na migração de células inflamatórias no modelo de inflamação alérgica pulmonar. 
Um dos mecanismos mais relevantes da modulação da resposta imune pelo estresse via ativação do eixo HPA desenvolve-se por alterações no chamado balanço TH1/TH2 (KIECOLT-GLASER et al., 2001). Basicamente o que diferencia as duas populações de linfócitos são as citocinas liberadas; os linfócitos Th1 (imunidade celular) caracterizam-se pela expressão de citocinas pró-inflamatórias, tais como interleucinas (IL) IL-2, IL-12, Interferon- $\gamma$ (ITF- $\gamma)$ e TNF- $\alpha$, resultando em uma diferenciação de macrófagos, células Natural Killer (NK) e células T citotóxicas, que estão envolvidas na fagocitose e destruição de bactérias invasoras ou corpos estranhos. A imunidade Th2 (Imunidade Humoral) caracteriza-se pela produção de citocinas antiinflamatórias, tais como IL-4, IL-9, IL-10, e IL13, resultando na diferenciação de eosinófilos, mastócitos e células $\mathrm{B}$, que leva a uma defesa a antígenos mediada por anticorpos (WEBSTER; TONELLI; STERNBERG, 2002). Então, quando produzidas, IL-12 e TNF- $\alpha$ aumentam a resposta imune inata ou Th1 e inibem as respostas do tipo humoral ou Th2 (ABBAS; MURPHY; SHER, 1996). As IL-4 e IL-10 produzem efeito oposto, ou seja, deslocam o equilíbrio Th1/Th2 para o padrão Th2. No caso de um estresse agudo, via secreção de glicocorticóides há um favorecimento das respostas do tipo Th2 (IWAKABE et al., 1998). Eles inibem a produção de IL-12, IFN- $\gamma$ e TNF- $\alpha$ por células apresentadoras de antígenos e células Th1, mas induzem ao aumento de produção de IL-4, IL-10 e IL-13 por células Th2. Em decorrência, pode-se dizer que os glicocorticóides podem suprimir uma resposta imune celular do tipo Th1 e aumentar uma resposta humoral mediada por células Th2 (BLOTTA; DEKRUYFF; UMETSU, 1997; ELENKOV, 2004). Com isso observa-se uma diminuição da resposta imune celular e um aumento daquela humoral o que torna o paciente estressado mais susceptível a alergias e doenças auto-imunes mediadas por anticorpos (ELENKOV et al., 2000; BASHIR et al., 2004).

Além do eixo HPA, outro importante mecanismo ativado durante o estresse esta ligado ao o Sistema Nervoso Autônomo Parassimpático (SNAP), denominado de via colinérgica antiinflamatória que controla principalmente a resposta inflamatória de forma reflexa e não consciente (TRACEY, 2002; 2007) e o Sistema Nervoso Autônomo Simpático (SNAS). A estimulação deste sistema leva à liberação de noradrenalina (NOR) nos terminais nervosos simpáticos e à secreção de adrenalina (ADR) pela adrenal (MAIER, 2003). Besedovsky e Del Rey em 1979 e 1981 foram os primeiros a demonstrar que uma ativação do SNAS regulava a resposta de anticorpos (SANDERS; KAVELAARS, 2007). Sabe-se que as fibras simpáticas terminam em íntimo contato com os órgãos linfóides primários e secundários (MADDEN; FELTEN, 1995); sabe-se, também, que as células desses órgãos possuem adrenoceptores e são passíveis à ação das catecolaminas como a adrenalina e a 
noradrenalina, como por exemplo, os linfócitos que possuem receptores adrenérgicos (QIU et al., 2005). Além disso, monócitos e macrófagos expressam receptores $\alpha$ (KAVELAARS, 2002) e macrófagos alveolares possuem alta densidade de $\beta_{2}$-adrenoceptores (ALVES; PALERMO-NETO, 2007).

O número de receptores $\beta_{2}$ adrenérgicos expressos nas células imunes é variável e pode ser regulado por diversos fatores, incluindo-se aqui a ativação celular, a presença de citocinas, hormônios e neurotransmissores. A estimulação de receptores $\beta_{2}$ adrenérgicos induz um aumento de AMPc e subsequente ativação de proteína kinase A. Além disso, essa estimulação ativa outras vias de sinalização intermediárias, como a MPA kinase (NANCE; SANDERS, 2007). Dessa forma, a liberação de catecolaminas pode aumentar (SCHEDLOWSKI et al., 1993; MADDEN et al., 1994; BENSCHOP; RODRIGUEZFEUERHAHN; SCHEDLOWSKI, 1996; DHABHAR; MCEWEN, 1999) ou diminuir (KOFF; DUNEGAN, 1986; CUNNICK et al., 1990; ALVES et al., 2006) a atividade de células do sistema imune. A figura 2 ilustra as inervações do Sistema Nervoso Autônomo.

Figura 2- Inervações do Sistema Nervoso Autônomo nos respectivos órgãos

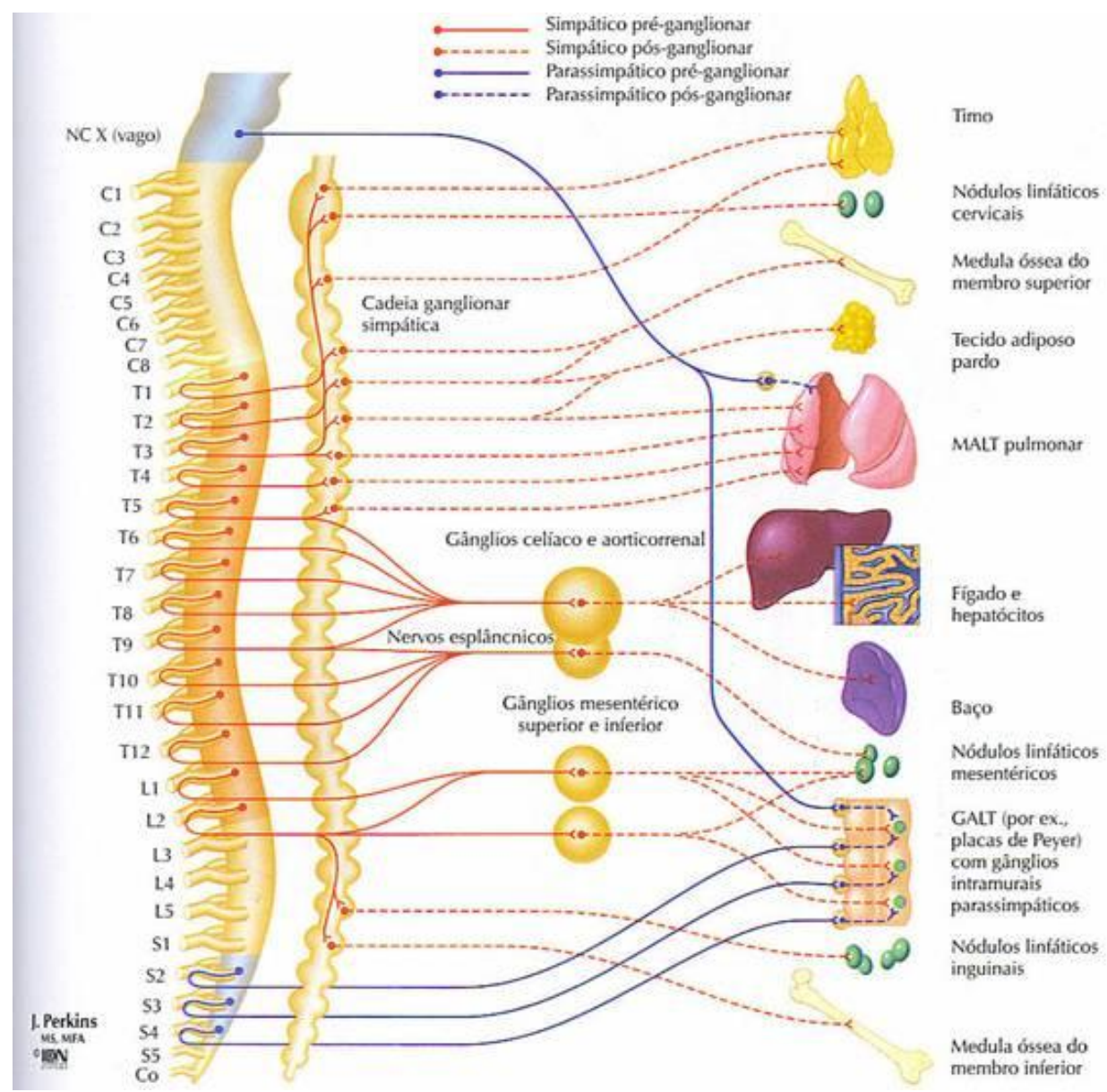

Fonte: http://www.sistemanervoso.com/pagina.php?secao=2\&materia_id=465\&materiaver=1 
Como as células Th2 maduras não expressam receptores $\beta_{2}$ adrenérgicos, a NOR não afeta, diretamente, a produção das citocinas tipo Th2; porém, ao diminuir a produção de citocinas do tipo Th1, pode, indiretamente, aumentar a produção de citocinas ligadas à imunidade humoral. A maioria dos dados da literatura aponta para a NOR uma ação antiinflamatória, por inibir a expressão de citocinas pró-inflamatórias do tipo Th1 (PANINABORDIGNON et al., 1997; BORGER et al., 1998; KALINICHENKO et al., 1999; MALARKEY et al., 2002). Ou seja, na esfera de imunidade inata, a NOR pode inibir drasticamente a produção e a secreção de TNF- $\alpha$ (IGNATOWSKI; GALLANT; SPENGLER, 1996). Além disso, após um estímulo estressor (choque nas patas, por exemplo) os níveis plasmáticos e esplênicos de TNF- $\gamma$ de animais estimulados com Lipopolissacarídeo (LPS) foram drasticamente suprimidos (MELTZER et al., 2004). Na esfera da imunidade adquirida, assim como os glicocorticóides, as catecolaminas podem dirigir a resposta Th2 em detrimento daquelas do tipo Th1. A NOR e a ADR ex vivo foram capazes de inibir a produção de IL-12 e de aumentar a produção de IL-10 em uma cultura de sangue total estimulada com LPS, sendo a ligação das catecolaminas a receptores $\beta_{2}$ adrenérgicos responsável por estes efeitos (ELENKOV et al., 1996).

$\mathrm{Na}$ tentativa de melhor compreender estes mecanismos neuroimunes ligados ao SNA, Brough-Holub e colaboradores mostraram que ratos submetidos a estresse apresentavam maior liberação de IL-1 $\beta$ (pró-inflamatória) por macrófagos alveolares; mostraram também que este efeito era revertido pelo bloqueio prévio da atividade do SNAS e, em especial dos $\beta_{2}$-adrenoceptores, minutos antes da indução do estresse. Além disso, mostraram que os animais estressados não apresentaram níveis elevados de corticosterona ou ACTH, dados que reforçavam a participação do SNA no fenômeno que analisaram (BROUG-HOLUB et al., 1998).

Ainda sobre o papel do SNA nos processos neuroimunes, Del Rey e colaboradores estudaram animais inoculados com um superantígeno chamado Staphylococcal Enterotoxin B (SEB); mostraram que dois dias após a inoculação estes animais apresentavam aumento dos níveis plasmáticos de IL-2 e proliferação de linfócitos T esplênicos; estes mesmos autores relataram que estes parâmetros estavam diminuídos quando os animais eram previamente tratados com 6-hidroxi-dopamina (6-OHDA), por via sistêmica, uma substância que induz denervação simpática (DEL REY et al., 2002). Observou-se, ainda que estes animais tratados com 6-OHDA por via intra-cérebro-ventricular (i.c.v), apresentaram uma diminuição tanto dos níveis de adrenalina e noradrenalina no hipotálamo como também de imunidade, conforme observado através da proliferação de linfócitos sanguíneos e de esplenócitos, da 
produção de IL-2 e de IFN- $\gamma$ e da expressão de mRNA para IL-2 em esplenócitos (PACHECO-LOPEZ et al., 2003). Neste mesmo trabalho, os autores constataram que estes efeitos imunológicos não estavam correlacionados com a ativação do eixo HPA e que eram eliminados através da realização de simpatectomia periférica, evidenciando-se, mais uma vez, a importância dos mecanismos simpáticos para a modulação de uma resposta imune (PACHECO-LOPEZ et al., 2003).

Outra abordagem tem se mostrado extremamente interessante na compreensão da influência de núcleos do SNC sobre respostas imunológicas em curso: aquela que faz o uso de lesões experimentais. Nesse sentido, a contribuição do grupo de Jankovic foi muito relevante, ao demonstrar que lesões do lócus ceruleus, núcleo do tronco encefálico que tem maior concentração de neurônios noradrenérgicos do SNC, levavam a uma diminuição tanto da produção de anticorpos contra albumina como do número de células T CD4+ circulantes e, ainda, a uma atrofia do timo e a uma supressão de hipersensibilidade tardia a albumina (JOVANOVA-NESIC; NIKOLIC; JANKOVIC, 1993; NIKOLIC; JOVANOVA-NESIC; JANKOVIC, 1993). Fatos que corroboram a existência de uma inervação simpática de órgãos linfóides e da influência dessa inervação sobre a maturidade de células $\mathrm{T}$, e da presença de receptores $\beta$-adrenérgicos em linfócitos.

Em 1975 Hugo Besendovsky avaliou a interação entre os sistemas imune e neuroendócrino, demonstrando que a imunização com diferentes antígenos era capaz de induzir mudanças neuroendócrinas e de atividade no SNC. Nascia então o outro braço da neuroimunomodulação: o estudo dos efeitos de produtos originários de processos imune/inflamatórios sobre a atividade do SNC. Foram então, relatadas as primeiras evidências realmente diretas das relações neuroimunes que demonstraram ser a ativação do sistema imune capaz de aumentar a razão de disparo de neurônios hipotalâmicos, sugerindo este fato que o sistema imune estaria envolvido com alterações comportamentais (BESEDOVSKY; SORKIN, 1977).

Um dos campos desta área da neuroimunomodulação onde existe pouco consenso diz respeito às vias através das quais o SI sinalizaria o SNC. Adrian Dunn (2002) revisou e agrupou possíveis mecanismos dessa sinalização, dentre eles destacam-se: 1) uma ação direta dos mediadores do SI nos locais onde a barreira hematoencefálica é mais permeável, como nos órgãos circunventriculares (que recebem esse nome por se localizarem nas proximidades dos ventrículos cerebrais e cujo endotélio é fenestrado, não apresentando junções oclusivas entre as células; 2) uma ação de mediadores do SI em aferência periférica do SNC, como nas terminações do nervo vago, (sem sombra de dúvidas o mais estudado quanto à capacidade de 
sinalização de respostas inflamatórias ou imunológicas para o SNC e 3) uma ação de mediadores do SI em locais que funcionariam como interface entre o sistema imunológico e o SNC, sem a necessidade da transferência direta do mediador para dentro deste (por exemplo, citocinas ligando-se a seus receptores no endotélio da microvasculatura cerebral, gerando mensageiros lipídicos como os prostanóides que podem transitar através de barreiras) (DUNN, A. J., 2002).

Neste sentido, Besedovsky et al. (1975) mostraram, de maneira pioneira, que um aumento na produção de anticorpos induzido por hemácias de carneiro era acompanhado de um aumento de aproximadamente até três vezes nas concentrações séricas de corticosterona. Estes mesmos autores mostraram um aumento de até $100 \%$ na atividade elétrica da área ventromedial do hipotálamo de ratos durante o pico da formação de anticorpos em resposta a uma imunização prévia (BESEDOVSKY; SORKIN, 1977; BESEDOVSKY et al., 1977). Posteriormente foi demonstrado que dentre os fatores liberados por leucócitos, a administração de IL-1 (mas não o TNFa, IL-2 ou IFN- $\gamma$ ) induzia a um aumento não somente dos níveis circulantes de corticosterona, mas também do hormônio adrenocorticotrófico (ACTH) (BESEDOVSKY et al., 1986). O envolvimento da liberação do fator liberador de corticotrofina (CRF) como um evento essencial para a ativação do eixo HPA induzido por IL1, foi subsequentemente estudado, sugerindo a existência de um circuito de feedback imunoregulatório, entre o SI e SNC (DEL REY et al., 1987). Alguns autores sugerem que esse circuito tenha um relevante papel no controle de reações inflamatórias exacerbadas e expansão inespecífica de células imunes (BESEDOVSKY; DEL REY, 2000; BOTASSO et al., 2009; ROGGERO et al., 2009).

Substâncias liberadas por células do sistema imune são capazes de modular a atividade de áreas específicas do SNC e, dessa forma, também o comportamento animal. Neste sentido, a produção e liberação de citocinas provocam uma resposta endócrina desencadeada pela ação direta e/ou indireta destas no SNC. As citocinas, de um modo geral, são mediadores solúveis produzidos por células imunes ativadas que servem de comunicação célula a célula no sistema imune (DANTZER; KELLEY, 2007), os efeitos atribuídos às citocinas no SNC podem ser agrupados em três categorias: 1- interação das citocinas com o sistema nervoso periférico (SNP), 2- efeitos centrais mediados pelas citocinas, 3- efeitos diretos das citocinas no SNC (ROTHWELL; HOPKINS, 1995). São descritas duas vias principais de comunicação pelos quais as citocinas interferem com o comportamento animal: uma via neural mais rápida e uma via humoral mais lenta (KONSMAN; PARNET; DANTZER, 2002). A via neural, como já comentado, é representada por neurônios aferentes, como o nervo vago, cujas 
terminações inervam os órgãos da cavidade peritoneal. Desta forma, macrófagos e células dendríticas estão dispostos em íntimo contato com a bainha perineural das fibras vagais, as quais expressam receptores para IL-1, por exemplo. O papel do nervo vago na transmissão de informações da periferia ao SNC tem sido acessado por meio de experimentos que se valem de secção do nervo (vagotomia diafragmática). Desta forma, as vias vagais aferentes parecem mediar, ao menos parcialmente, o comportamento doentio induzido por LPS ou IL-1. Já a via humoral envolve a produção de interleucinas que podem atravessar a barreira hematoencefálica e interagir com as células da microglia; envolve, também, a produção de mediadores inflamatórios por células endoteliais, em especial, a prostaglandina $\mathrm{E}_{2}\left(\mathrm{PGE}_{2}\right)$ (KONSMAN; PARNET; DANTZER, 2002).

A primeira tentativa de estruturação conceitual acerca do comportamento de animais doentes veio de Benjamin Hart, que compilou informações de diversas espécies animais acometidos por uma ampla gama de processos patológicos (HART, 1988). Ele agrupou alguns achados comuns a todas as espécies e processos estudados, que incluíam febre, letargia ou prostração, perda de apetite e diminuição do consumo de água, diminuição de locomoção em geral, (mas com maior importância daquele dirigida à exploração ambiental) redução de autolimpeza (evidente em roedores) entre outros. A opinião de Hart foi clara: o conjunto de alterações apresentadas por animais doentes, coletivamente denominados de comportamento doentio, estava longe de ser resultado de uma depressão geral e inespecífica do SNC; correspondia, sim, a um conjunto organizado de modificações fisiológicas e comportamentais, isto é, existia uma base biológica (e não patológica) para o comportamento dos animais doentes. No mesmo trabalho são listadas possíveis vantagens (aparentemente paradoxais) de alterações comportamentais para os animais acometidos de doenças, tais como diminuição do gasto energético fisiológico com a digestão de comida (anorexia), menor perda de calor e exposição a possíveis predadores (prostração) e geração de um ambiente menos favorável à proliferação de patógenos, favorecida pela atividade de células imunológicas (febre) (HART, 1988).

Resultados de nosso grupo parecem corroborar o caráter motivacional e adaptativo das alterações comportamentais em animais doentes. Daniel Cohn estudou as alterações causadas pelo LPS em camundongos dominantes e submissos acondicionados em duplas estáveis. Este autor descreveu um efeito maior dessa molécula em animais dominantes, que apresentaram letargia e diminuição da busca pela interação social (com um submisso tratado com salina) do que nos submissos, quando a situação era invertida, ou seja, quando o submisso recebia LPS e o dominante solução salina (COHN; KINOSHITA; PALERMO-NETO, 2012). Assim, as 
obrigações sociais de um animal subordinado a outro dentro da dupla talvez impeçam a expressão do comportamento doentio, refletindo este fato uma maior prioridade do animal, naquele momento para outras atividades. Além disso, o modelo utilizado pelo autor foi útil em evidenciar possíveis decorrências sociais do comportamento doentio; em algumas duplas, a administração de LPS no animal dominante resultou em uma desestabilização da hierarquia existente, levando as situações de conflito, nas quais o animal previamente submisso expressava comportamento agressivo em relação ao dominante doente (incomum em duplas estáveis) chegando até mesmo a evidenciar embates físicos, com aparecimento de lesões nos camundongos previamente dominantes (COHN; KINOSHITA; PALERMO-NETO, 2012).

Em um estudo mais recente, utilizando animais knockout, mostrou-se que a liberação, na periferia e/ou no SNC, de IL-1 e IL-6 induzidas por lipopolissacarídeo (LPS) tem papel central no aparecimento do comportamento doentio (BLUTHE et al., 2000). Em nossos laboratórios, utilizando-se modelos experimentais de reação alérgica intestinal foi demonstrado em camundongos um aumento de ansiedade observada no campo aberto e no labirinto em cruz elevado e aumento na expressão de $c$-Fos no núcleo paraventricular do hipotálamo (PVN) e no núcleo central da amígdala (BASSO et al., 2003). Adicionalmente, em um modelo de alergia pulmonar mostrou-se que animais que haviam sido previamente imunizados com OVA, um aumento de aversão ao lado escuro de uma caixa de esquiva passiva após associação deste lado com uma nebulização com OVA; esses animais mostraram ainda um aumento da atividade de células do núcleo ventromedial do hipotálamo e da região basolateral da amígdala (COSTA-PINTO et al., 2005). Mostrou-se também, que a remoção de IgE (por depleção do anticorpo utilizando um anti-IgE) preveniu estes efeitos (COSTAPINTO et al., 2006).

\subsection{ESTRESSE E IMUNIDADE}

Um corpo crescente de evidências mostra a relevante relação entre o estresse e a ocorrência de variações na função imune (PALERMO-NETO; DE OLIVEIRA MASSOCO; ROBESPIERRE DE SOUZA, 2003). Como mostrado anteriormente a ativação do eixo HPA e do SNS em resposta ao estresse alteram tanto a capacidade funcional quanto o padrão migratório das células do sistema imune. Estas alterações são dependentes das características do agente estressor, em especial, de sua intensidade, tipo (fisiológico ou psicológico) e tempo 
de exposição (agudo ou crônico) (SAPOLSKY; ROMERO; MUNCK, 2000; DHABHAR, 2002; 2003; ENGLER et al., 2004), e também são dependentes das características comportamentais existentes e estratégias de coping do indivíduo submetido ao estressor (VEGAS et al., 2006; AZPIROZ et al., 2008). As respostas elaboradas em consequência destes estímulos são geralmente adaptativas em curto prazo; no entanto, podem também ser prejudiciais, especialmente quando o estímulo estressor se mantém por um período prolongado ou crônico (SELYE, 1998; SAPOLSKY; ROMERO; MUNCK, 2000; DHABHAR, 2003; MCEWEN, 2007).

A influência da atividade do sistema neuroendócrino sobre o sistema imunológico foi explicada magistralmente por Hans Seyle em um artigo que se tornou um marco na história do estudo do estresse (REICHE; NUNES; MORIMOTO, 2004). Selye descreveu de forma pioneira, o desenvolvimento de uma síndrome decorrente da exposição de um animal a um conjunto muito diversificado de estímulos nocivos que incluía exposição ao frio, injuria tecidual, excesso de exercícios e intoxicações, entre tantos outros. Os achados característicos dessa síndrome foram hipertrofia das glândulas adrenais, aparecimento de úlceras gástricas e, curiosamente para a época, atrofia de órgãos linfóides, incluindo-se aqui baço, timo e linfonodos. Como tais achados eram independentes do agente empregado, Selye concluiu que representavam uma resposta orgânica à injuria, denominando-os coletivamente de 'síndrome geral da adaptação', que posteriormente passou a ser chamada de estresse. Desse trabalho nasciam dois conceitos fundamentais sobre o estresse: 1) a resposta aos estressores parecia ser adaptativa, representando uma tentativa do organismo de acomodar-se a uma nova situação, e 2) ela não dependia do estímulo, sendo estereotipada (SELYE, 1998).

Recente revisão dos trabalhos de nosso grupo mostra os resultados de diferentes tipos de estressores sobre parâmetros neuroquímicos, comportamentais e imunes (COSTA-PINTO; PALERMO-NETO, 2010). A neuroimunomodulação também tem sido envolvida com a resistência orgânica à progressão de tumores. Mostrou-se um forte vínculo entre presença de estresse, alterações da função imune e sensibilidade ao câncer (COHEN, S.; HERBERT, 1996).

Variações psicológicas assim como estados de ansiedade e depressão induzidos por estímulos estressores podem interferir com a imunidade. De fato, já foram descritas alterações induzidas pelo estresse como uma redução significante na atividade de células Natural Killer (NK), na atividade de macrófagos e neutrófilos, na proliferação de linfócitos T e B, alterações estas associadas a uma redução significante da resistência ao desenvolvimento de infecções e de neoplasias em animais de laboratório (WU et al., 2000; FONSECA; MASSOCO; 
PALERMO-NETO, 2002; MORGULIS et al., 2004; SA-ROCHA; SA-ROCHA; PALERMONETO, 2006; ALVES; VISMARI; PALERMO-NETO, 2007; PALERMO-NETO et al., 2008; QUEIROZ JDE et al., 2008). Em nossos laboratórios, Fonseca, Massoco e PalermoNeto (2002) mostraram que um estresse aplicado em fêmeas gestantes, interferia com parâmetros comportamentais e com a atividade de macrófagos da prole. Mais especificamente, estes autores observaram que uma prole de camundongos estressada no período pré-natal apresentava uma maior atividade locomotora avaliada no campo aberto e um menor índice de espraiamento de macrófagos peritoneais. Além disso, estes mesmos autores mostraram que estresse aplicado durante a fase pré-natal interferia com a responsividade de alguns parâmetros da resposta imune da prole de camundongos submetidos a um estresse pós-natal, ou seja, mostraram que havia um aumento da produção de $\mathrm{H}_{2} \mathrm{O}_{2}$ e uma diminuição do índice de fagocitose no grupo de animais estressados pré e pós- natal quando estes eram comparados ao grupo de animais estressados apenas pós-natal (FONSECA; MASSOCO; PALERMO-NETO, 2002). Em outro trabalho semelhante, mostrou-se que camundongos estressados durante a fase pré-natal apresentaram aumento dos níveis de ansiedade, diminuição dos índices de espraiamento e fagocitose por macrófagos peritoneais e, também, aumento do crescimento do Tumor de Ehrlich em sua forma sólida e ascítica (PALERMO NETO; MASSOCO; FAVARE, 2001).

Palermo-Neto; Massoco e Robespierre de Souza (2003), relataram alterações comportamentais e imunológicas produzidas por estresse físico e psicológico em camundongos adultos. Neste trabalho os autores mostraram que um estresse psicológico, gerado pelo ato de observar outro animal receber choque inescapável, produzia respostas estressantes em tudo similares àquelas geradas pelo choque inescapável. Tanto o animal que recebia o choque inescapável na pata como o que presenciava a estimulação aversiva apresentaram um aumento do crescimento do tumor ascítico de Ehrlich, que foi avaliado através do número de células tumorais e do volume do fluido ascítico. Observaram também, uma redução dos índices de espraiamento e de fagocitose de macrófagos peritoneais obtidos destes animais e uma diminuição da atividade locomotora dos mesmos no campo aberto (PALERMO-NETO; DE OLIVEIRA MASSOCO; ROBESPIERRE DE SOUZA, 2003; PALERMO-NETO et al., 2008). Trabalho semelhante mostrou que este mesmo tipo de estresse induziu a uma mielosupressão e a uma piora no desenvolvimento de uma infecção experimentalmente induzida por Listeria monocytogenes (QUEIROZ et al., 2008). Sá-Rocha mostrou que animais submissos e mantidos em uma hierarquia social estável apresentavam diferenças no comportamento e na neuroquímica cerebral, respondendo de forma diferenciada 
daquela dos dominantes a idênticos estímulos imunes. Em especial, os animais submissos apresentavam, em relação aos dominantes, maiores níveis de ansiedade, menor atividade de células NK no baço e maior susceptibilidade ao desenvolvimento de metástases tumorais pulmonares induzidas pelo implante de melanoma B16/F10 (SA-ROCHA; SA-ROCHA; PALERMO-NETO, 2006).

Strange et al. (2000) mostraram que camundongos machos submetidos a estresse psicosocial e inoculados com um tumor andrógeno responsivo (AR SC115) apresentavam menor resposta à quimioterapia e, também, uma menor sobrevida, dependendo dos efeitos observados e do tipo de estresse aplicado. Estas evidências justificam a grande preocupação dos pesquisadores com esta área de pesquisa, também chamada de psico-oncologia. Desta forma, outros trabalhos têm sido realizados em seres humanos buscando avaliar a necessidade de se completar os tratamentos convencionais (quimioterapia e radioterapia, por exemplo) com outros ligados ao uso de psicofármacos e/ou a um acompanhamento psicológico que, de alguma forma, auxiliem o paciente a reduzir seus níveis de ansiedade, apresentando, quem sabe, uma melhor qualidade de vida (STRANGE et al., 2000; ANDERSEN et al., 2004; DAVIDSON; MILBURN; WILSON, 2004).

\subsection{A CONVIVÊNCIA COM ANIMAIS DOENTES}

É notória a quantidade de eventos que podem acarretar uma vida "estressada". O termo estresse já foi, há muito, incorporado ao nosso vocabulário cotidiano designando desde situações banais até outras mais complicadas. Dentre as inúmeras situações capazes de gerar estresse, o convívio e o ato de cuidar de doentes têm sido considerados relevantes estressores que, de modo geral se estendem por longos períodos. Essa convivência afeta, principalmente os familiares ou pessoas próximas do indivíduo doente. Muitos destes "caregivers" não realizam estas atividades por escolha, mas por necessidade pelo fato de ser o doente um parente próximo. Esta atividade exige dedicação exclusiva em alguns casos, fato que os leva a interromper suas atividades sociais e relacionamentos, resultando em perdas de amizade e de recursos financeiros e, eventualmente isolamento social, outro evento que também tem sido considerado estressor (NAVAIE-WALISER; SPRIGGS; FELDMAN, 2002).

$\mathrm{O}$ estresse gerado pelo ato de acompanhar pacientes com enfermidade crônica tem sido associado em humanos a alterações de imunidade inata e humoral, queda de resistência 
orgânica a infecções e aparecimento de sintomas psiquiátricos, como ansiedade e depressão (ALVES; VISMARI; PALERMO-NETO, 2007; ALPI et al., 2008; FREDMAN et al., 2010; JIWA et al., 2010). Millset al. (1999) avaliaram o sangue de caregivers através de citometria de fluxo e, também, as concentrações de catecolaminas no plasma, através de ensaio radioenzimático. Observaram que os caregivers tinham menores níveis de linfócitos CD8+e CD4+, e menores níveis de L selectina negativa (CD8+CD62L-) e (CD4+CD62L-); no entanto, não detectaram diferenças nos níveis de CD62+ tanto em CD8 como em CD4. Observaram, ainda, que os níveis de adrenalina estavam significantemente maiores nos caregivers. Nesse sentido, os autores propuseram que os altos níveis de adrenalina observados nos caregivers induziam a redução que observaram do número de células T CD62L- na circulação (MILLS et al., 1999).

Bauer et al. (2000) relataram que cônjuges de pacientes portadores do mal de Alzheimer apresentavam níveis elevados de cortisol na saliva, indicando este achado a ocorrência de uma ativação do eixo HPA, associada a uma diminuição da imunidade mediada por células, como demostrado in vitro através da redução da proliferação de linfócitos induzida por mitógenos e da produção de IL-2. Também observaram uma redução da sensibilidade dos linfócitos aos glicocorticóides, isto é, os linfócitos de caregivers aparentavam ser mais resistentes aos esteróides. Contudo, os autores mostraram que caregivers com altos níveis de estresse apresentavam, também, altos níveis plasmáticos de noradrenalina, confirmando e sugerindo este achado a ocorrência concomitante de ativação do SNAS nestes indivíduos (BAUER et al., 2000).

Assim como as pessoas, os animais precisam de um relacionamento social saudável e parecem responder de forma semelhante a estresses psicológicos (ALVES; PALERMONETO, 2007). Engler et al. (2004) investigaram em ratos, o papel dos mecanismos adrenérgicos na modulação neuroendócrina e sua interferência na circulação dos leucócitos diante de uma situação de estresse social; relataram que as catecolaminas apresentavam um importante papel na redistribuição dos leucócitos sanguíneos durante este estresse. Neste contexto, mostrou-se que a mobilização de células ligadas à resposta imune inata é regulada por mecanismos adrenérgicos. A mobilização de fagócitos e de células NK pelas catecolaminas indicaria, assim, uma conexão funcional entre o SNC e a resposta imune inata. Sabe-se então, que em uma situação de estresse persistente e de longo prazo pela convivência com um doente, o aumento da atividade catecolaminérgica pode promover uma desregulação da função imune o que propiciaria o aparecimento de doenças (ENGLER et al., 2004). 
Avaliando parâmetros comportamentais e imunes de camundongas que conviveram com companheiras doentes (portadores de um tumor ascítico de Ehrlich) por 11 dias observamos em nossos laboratórios o aparecimento de leucopenia nestes animais e, apesar da presença de níveis normais de corticosterona, eles mostraram-se mais suscetíveis ao desenvolvimento do mesmo tumor experimental, ao fim do período de convívio com o companheiro doente (MORGULIS et al., 2004). Ainda em nossos laboratórios, empregando este mesmo modelo experimental, Alves et al. (2006), em seqüência, mostraram que camundongas que coabitaram por 11 dias com conspecíficas doentes apresentavam aumento de atividade motora no campo aberto e diminuição da resistência orgânica ao crescimento de um tumor ascítico de Ehrlich, como ilustra a figura 3. Esta convivência com um animal doente induziu também (a) uma diminuição nos níveis e um aumento do turnover hipotalâmico de NOR; (b) diminuição no burst oxidativo de neutrófilos após a indução com miristato acetato de forbol (PMA) ou com Staphylococcus aureus; (c) uma diminuição na porcentagem e na intensidade de fagocitose de neutrófilos (ALVES et al., 2006). A fagocitose de macrófagos peritoneais também foi menor nas camundongas que conviveram com conspecíficas doentes em relação ao grupo controle, ou seja, animais que haviam convivido com companheiras saudáveis (ALVES; VISMARI; PALERMO-NETO, 2007).

Figura 3- Esquema ilustrativo do grupo experimental utilizado nesta dissertação. O animal companheiro será o objeto experimental deste trabalho

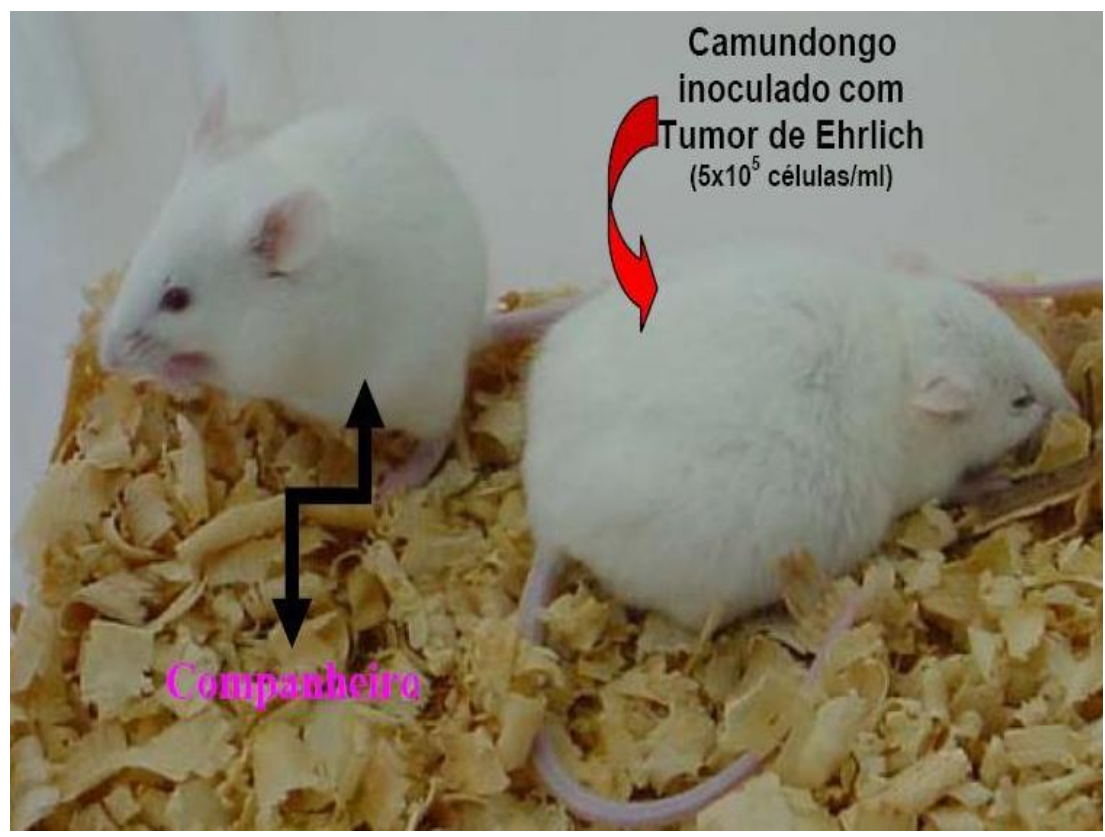

Fonte: (ALVES, G. J., 2006 adaptado por MACHADO, T. R. M., 2013) 
De relevância, observaram também em camundongas que conviveram com portadoras do mesmo tumor por 14 dias: 1) redução do peso e da celularidade do baço; 2) redução na contagem diferencial de blastos, eritrócitos jovens e linfócitos no esplenograma; 3) redução da porcentagem de linfócitos B e T helper e na proporção CD4/CD8 no baço; 4) aumento da atividade citotóxica de células NK; 5) aumento da celularidade total da medula; 6) aumento do número absoluto de blastos e redução daquele de eritrócitos jovens e de linfócitos no mielograma, e aumento do número relativo de blastos; 7) aumento de células em fase G1 e redução daquelas em fase G2 do ciclo celular da medula; 8) aumento de células tumorais em fase G1 e redução daquelas em fase G2 do ciclo celular do tumor ascítico de Ehrlich, 9) aumento do tempo de permanência com um animal estranho e redução deste tempo de permanência junto à companheira doente em um labirinto em $\mathrm{T}, 10$ ) aumento de interação social, 11) uma redução do burst oxidativo basal de neutrófilos provenientes de animais que conviveram com dois doentes, e reversão destas alterações quanto da convivência de um doente com dois sadios, 12) a convivência não modificou os níveis de corticosterona dos animais desafiados ou não por contenção, 13) os níveis de adrenalina e noradrenalina plasmáticas estavam aumentados 2, 4 e 9 dias após a convivência com um animal doente. Contudo observou-se neste trabalho, uma significante diminuição de catecolaminas foi observada após 14 dias de convivência com o companheiro doente e, ainda, que o contato físico e visual não eram relevantes para o aparecimento das alterações induzidas pela convivência. No entanto e, muito relevante, observaram que estímulos olfativos provenientes do doente eram fundamentais para a manifestação das alterações induzidas pela convivência sobre o burst oxidativo e fagocitose de neutrófilos, crescimento tumoral, alterações comportamentais, níveis plasmáticos de noradrenalina e adrenalina, níveis hipotalâmicos de noradrenalina (ALVES et al., 2010; ALVES; RIBEIRO; PALERMO-NETO, 2012). Estes resultados, em seu conjunto, levaram os autores a sugerir que as alterações que observaram eram decorrentes de um aumento de atividade catecolaminérgica no SNC e, provavelmente, de uma ativação do SNAS. Estes autores verificaram, ainda e mais uma vez, que: a convivência não modificou os níveis de corticosterona dos animais desafiados ou não por contenção (ALVES et al., 2006; ALVES; VISMARI; PALERMO-NETO, 2007; ALVES et al., 2010).

Em outro trabalho do nosso grupo foram analisados os efeitos de uma convivência com animal doente empregando outra linhagem de camundongas (C57B1/6) e outro tipo de tumor, o melanoma (B16F10). Mostraram aqui também, um aumento da atividade motora dos animais companheiros observados em campo aberto e alteração do comportamento dos 
mesmos em um labirinto em cruz elevado; mostrou-se ainda, que a convivência com o doente, produziu um déficit na diferenciação de células dendríticas na presença de GM-CSF, IL-4, e LPS in vitro, resultando em uma menor porcentagem de células +CD80+ in vitro,aumento da expressão de moléculas co-estimulatórias CD80 e +CD11C+em células do baço analisadas in vitro e o desenvolvimento de uma hipersensibilidade do tipo tardia induzida por ovalbumina (TOMIYOSHI et al., 2009).

Analisando-se estes resultados em seu conjunto depreende-se que a convivência com um animal portador de um tumor de Ehrlich produziu relevantes alterações no comportamento e em parâmetros neuroquímicos e de atividade imune de camundongas, muito provavelmente desencadeadas pela estimulação olfativa proveniente da doente (ALVES et al., 2010). Fatos estes nos levam a sugerir que animais, em especial, roedores tem sua fisiologia e homeostase modificadas de forma marcante pela vivência com um companheiro doente. Sabendo que há diferenças hormonais e comportamentais entre machos e fêmeas, cabe-nos questionar se há diferença de resposta entre os sexos. Desta forma, o presente trabalho analisa os efeitos da convivência com um portador de um tumor ascítico de Ehrlich em camundongos machos. Analisa, ainda, nestes animais a participação do SNS e do eixo HPA e o envolvimento de citocinas na periferia e no SNC. 


\section{OBJETIVOS}

\subsection{OBJETIVO GERAL}

Avaliar em camundongos machos os efeitos da convivência por 11 dias com companheiros "doentes" inoculados com tumor ascítico de Ehrlich sobre parâmetros comportamentais, bioquímicos e de imunidade inata.

\subsection{OBJETIVOS ESPECÍFICOS}

1 Avaliar em machos que conviveram ou não com um conspecífico portador do tumor ascítico de Ehrlich:

- Os níveis de corticosterona sérica no $5^{\circ}, 7^{\circ}, 9^{\circ}$ e $11^{\circ}$ dia de convivência com o doente por ELISA.

- O peso relativo da glândula adrenal.

- Os níveis de adrenalina e noradrenalina plasmáticos no $11^{\circ}$ dia de convivência com o doente por ELISA.

- O burst oxidativo e fagocitose de neutrófilos por citometria de fluxo.

- A resistência ao crescimento de um tumor ascítico de Ehrlich.

- O comportamento no campo aberto.

- Os níveis de noradrenalina no hipotálamo, bulbo e no córtex frontal por HPLC.

- Os níveis de citocinas (IFN- $\gamma$, IL-12, IL-10, IL-6 e TNF- $\alpha$ ) no baço por CBA.

- Os níveis de citocinas (IL-1 $\beta$, IL-6 e TNF- $\alpha$ ) no Hipotálamo e no córtex frontal por PCR- real time.

2 Discutir o papel do gênero nos parâmetros analisados. 


\section{MATERIAIS E MÉTODOS}

\subsection{ANIMAIS}

Foram utilizados camundongos adultos da linhagem Swiss, com 7 a 9 semanas de idade, provenientes de proles obtidas no Biotério do Departamento de Patologia da Faculdade de Medicina Veterinária e Zootecnia da Universidade de São Paulo (FMVZ-USP). Os animais foram utilizados seguindo as normas e procedimentos éticos relativos ao uso de animais de laboratório do Comitê de Ética, processo 2404/2011 da FMVZ-USP.

Antes do início dos experimentos, os animais foram alojados, por um período de 7 dias, em gaiolas de propileno $(28 \times 17 \times 12 \mathrm{~cm})$ em número de 2 animais por gaiola para adaptação às condições do biotério experimental. Estas gaiolas foram acondicionadas em salas cuja temperatura ambiente $\left(24\right.$ a $\left.26^{\circ} \mathrm{C}\right)$ e umidade $(65 \%$ a $70 \%)$ foram controladas por meio de aparelhos de ar condicionado, ventilação e sistema de exaustão; a iluminação da sala foi artificial, e obedeceu a um ciclo de claro-escuro de 12 horas, com início da fase clara às 7:00 horas. Os animais foram alimentados com ração balanceada para roedores NUTRILABOR GUABI®. Ração e água foram fornecidas ad libitum durante todos os experimentos.

\subsection{FORMAÇÃO DOS GRUPOS}

Os camundongos foram separados em pares de acordo com o peso corporal, sendo estes obrigatoriamente da mesma prole, pois, sendo machos essa medida deve ser adotada a fim de se minimizar comportamento agressivo entre eles. Os animais foram mantidos em coabitação durante 7 dias. No oitavo dia (dia 0 dos experimentos) os pares de animais foram divididos ao acaso em dois grupos iguais: um controle e um experimental. Um camundongo de cada par do grupo controle foi inoculado com PBS i.p. (0,4ml/animal) e um camundongo de cada par do grupo experimental foi inoculado i.p. com uma suspensão de células do tumor

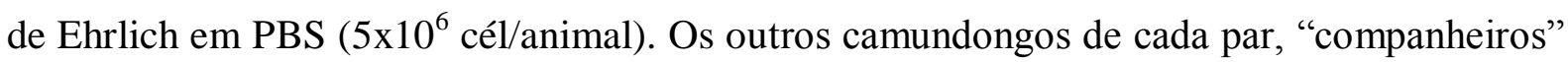
dos animais inoculados, não foram manipulados, sendo o objeto deste estudo. No $11^{\circ}$ dia de 
convivência, os procedimentos experimentais foram realizados com os "companheiros" dos animais saudáveis (CAS) ou doentes (CAD) como ilustra a figura 4.

Figura 4-Esquema ilustrativo da formação dos grupos experimentais deste trabalho

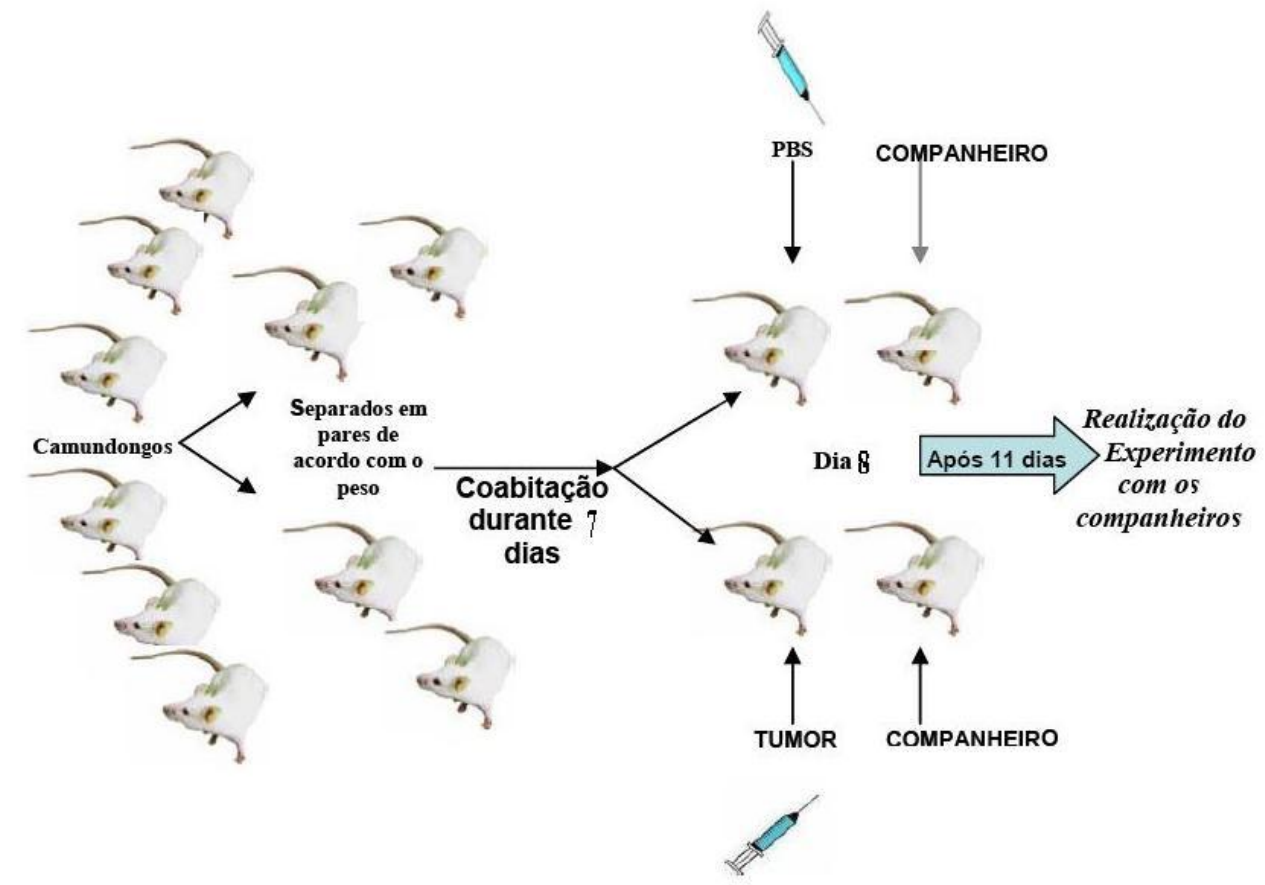

Fonte: (ALVES, G. J., 2006 adaptado por MACHADO, T. R. M., 2013)

\subsection{OBTENÇÃO E MANUTENÇÃO DO TUMOR ASCÍTICO DE EHRLICH}

Após eutanásia em câmara de $\mathrm{CO}_{2}$, foi feita a colheita do fluído ascítico de um camundongo doador, portador de um tumor ascítico de Ehrlich com 7 dias de evolução. A suspensão de células obtidas deste animal foi centrifugada a 1000 RPM, por 5 minutos sendo ressuspensa por três vezes em PBS. Foi realizado então a contagem e avaliação de viabilidade das células tumorais assim obtidas, usando-se para tal o azul de Tripan (1:200) e empregandose uma câmara de Neubauer.

Foi padronizado para uso nos camundongos chamados "doentes" nos experimentos deste trabalho um total de $1,25 \times 10^{7}$ células tumorais por ml de PBS, com no mínimo de $90 \%$ 
de viabilidade. Foi inoculado $0,4 \mathrm{ml}$ de uma suspensão de células tumorais com essa concentração no peritônio de cada camundongo $\left(5,0 \times 10^{6}\right.$ células tumorais por animal).

Para manutenção "in vivo" do tumor no laboratório, $0,1 \mathrm{ml}$ de fluído ascítico de um camundongo doador era inoculado semanalmente em um camundongo receptor.

\subsection{DOSAGEM DE CORTICOSTERONA SÉRICA NO $5^{\circ}, 7^{\circ}, 9^{\circ}$ E $11^{\circ}$ DIAS DE CONVIVÊNCIA COM O DOENTE POR ELISA}

A quantificação da corticosterona sérica foi realizada por um kit de ELISA (DetectX®- Corticosterone Enzyme Immunoassay Kit- Arbor Assays- Michigan USA), e os procedimentos foram realizados conforme as instruções do fabricante. O protocolo seguido encontra-se em http://www.arborassays.com/resources/lit.asp.

A colheita de sangue para a dosagem dos níveis séricos de corticosterona foi realizada por punção da veia submandibular usando-se uma micro lanceta para obtenção de um pequeno volume sanguíneo $(100$ a $200 \mu \mathrm{l})$ em microtubos de $1,5 \mathrm{ml}$ no $5^{\circ}, 7^{\circ}, 9^{\circ}$ e $11^{\circ}$ dias de convivência com o animal portador do tumor de Ehrlich para a avaliação da interação do eixo HPA. O sangue colhido dos animais CAS e CAD foi mantido à temperatura ambiente para a retração do coágulo e então centrifugado $\left(5000 \mathrm{rpm} / 5\right.$ minutos a $\left.4^{\circ} \mathrm{C}\right)$ para obtenção do soro. Este soro foi armazenado em microtubos de polietileno em freezer a $-80^{\circ} \mathrm{C}$ até o momento da realização das dosagens hormonais. O sangue foi colhido no mesmo período (8:00 às 10:00 horas) para evitar-se influências da variação circadianas nos níveis de corticosterona.

\subsection{PESO DA GLÂNDULA ADRENAL}

Após eutanásia dos animais em câmara de $\mathrm{CO}_{2}$, estes foram pesados e,em seguida, foram retiradas cirurgicamente as glândulas adrenais direita e esquerda através da abertura da cavidade abdominal. As glândulas foram pesadas em balança de precisão para a análise do peso relativo do órgão (Peso glândula adrenal/Peso total do animal). 


\subsection{DOSAGEM DE ADRENALINA E NORADRENALINA PLASMÁTICOS NO $11^{\circ}$ DIA DE CONVIVÊNCIA COM O DOENTE POR ELISA}

A quantificação de adrenalina e de noradrenalina plasmática foi realizada com o Kit 2CAT Plasma ELISA (Labor Diagnostica Nord GmbH\& Co. KG - LND ${ }^{\circledR}$ ) e os procedimentos foram realizados conforme as instruções do fabricante (http://www.ldn.de/products/biogenesamines-neuerocience/catecholamines/plasma/2-cat-plasma-elisa-high-sensitive).

O sangue utilizado para o estudo foi colhido imediatamente após a eutanásia dos animais por decaptação e colocado em microtubos de $1,5 \mathrm{ml}$ com $10 \mu \mathrm{l}$ de heparina. Após a colheita, o sangue foi centrifugado a 4000rpm por 5 minutos a fim de se coletar o plasma, foi adquirido $100 \mu 1$ de cada animal. Estas amostras ficaram armazenadas em eppendorffs de 200 $\mu 1$ em freezer $-80^{\circ} \mathrm{C}$ até a análise das mesmas pelo Kit acima descrito.

\subsection{BURST OXIDATIVO E FAGOCITOSE DE NEUTRÓFILOS POR CITOMETRIA DE FLUXO}

Foi utilizado um citômetro de fluxo (FACScalibur Becton Dickinson Immunocytometry System, San Jose, CA, USA) conectado com um computador (Machintosh Apple, CA, USA). Foram analisados 1000 eventos utilizando-se o software Cell Quest Pro (Becton Dickinson Immunocytometry System, San Jose, CA, USA) como ilustra a figura 5. 
Figura 5- Citômetro de Fluxo modelo FACScalibur da Becton Dickinson acoplado a um computador Machintosh (G4) da Apple utilizado no presente trabalho para avaliar a atividade de neutrófilos

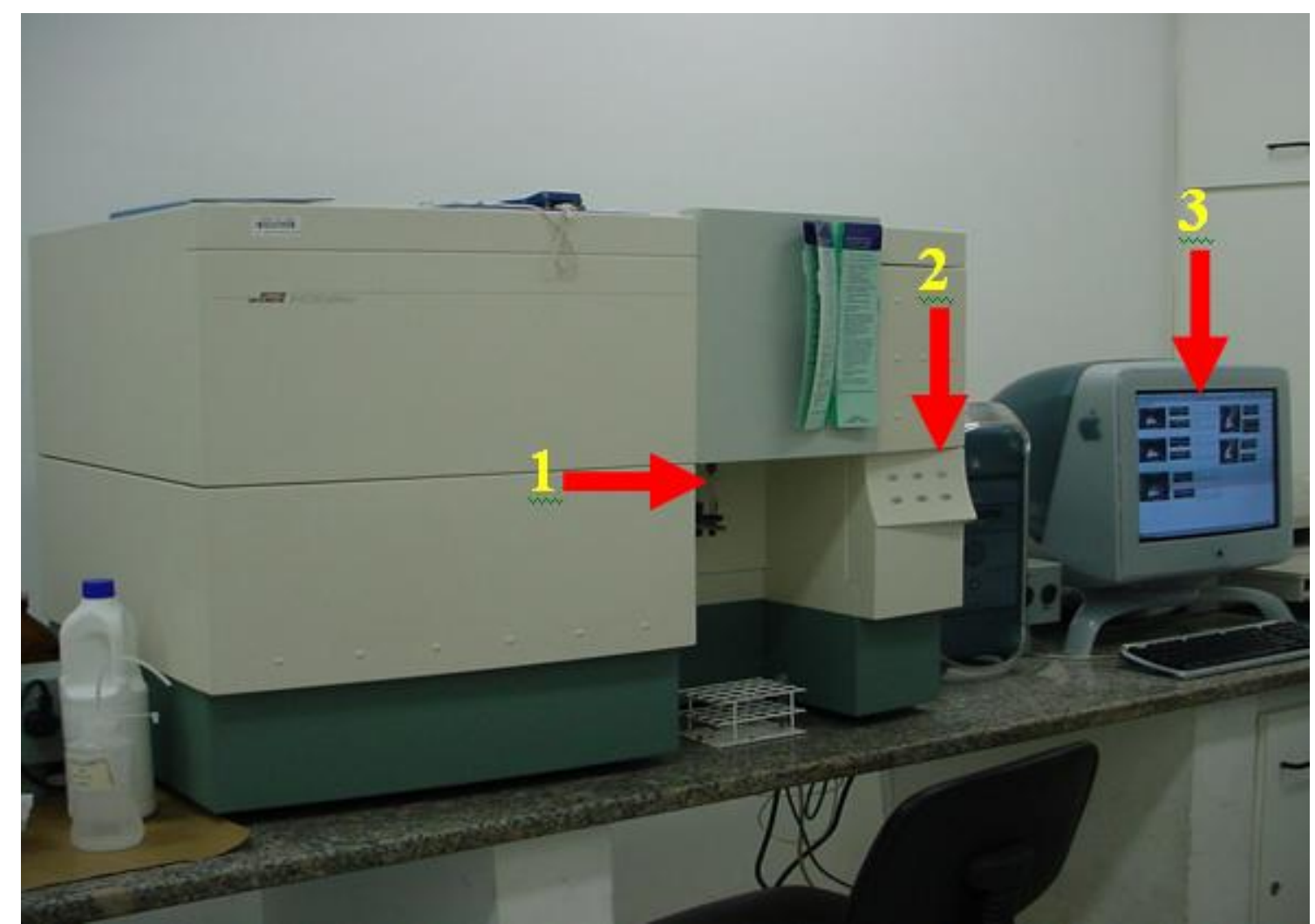

Fonte: (ALVES, G. J., 2006)

Legenda: As setas indicam: 1- Injeção da amostra, 2- Painel de controle do citômetro e 3- Gráficos dos dados adquiridos

As subpopulações celulares foram reconhecidas por meio das propriedades FSC Forward Scatter e SSC Scater do aparelho que avaliam o tamanho e a complexidade interna, dos mesmos respectivamente. A fluorescência verde do DCFH foi mensurada a $530 \pm 30 \mathrm{~nm}$ (detector FL1) sendo aquela de cor vermelha do S. aureus marcado com iodeto de propídeo mensurada a $585 \pm 42 \mathrm{~nm}$ (FL2). A fluorescência verde emitida pelo DCFH foi usada para estimar o burst oxidativo de neutrófilos em diferentes situações de estimulação. A fagocitose foi estimada pela intensidade média de fluorescência/célula emitida pelo PI. A porcentagem de fagocitose (porcentagem de neutrófilos que fagocitaram as bactérias) foi calculada através do número de neutrófilos fluorescentes divididos pelo número total destas células e multiplicado por 100. As fluorescências do PI e do DCFH foram analisadas utilizando-se compensação de fluorescências para corrigir quaisquer interferências de sinais emitidos pelos mesmos. Através do Cell Quest Pro ${ }^{\circledR}$ foram analisadas as populações de interesse em cada experimento, excluindo-se as populações de linfócitos e monócitos por meio da análise dos 
gates. Além disso, para todos os experimentos o aparelho foi calibrado com um tubo branco usado como controle de refringência basal da célula a ser analisada.

As células utilizadas para o estudo no citômetro de fluxo foram coletadas imediatamente após eutanásia dos animais por decaptação. O sangue foi coletado em microtubos de 1,5 $\mathrm{ml}$ com $10 \mu 1$ de heparina. Foram usadas amostras sangüíneas de $500 \mu 1$ para a análise do burst oxidativo e da atividade fagocítica.

O preparo das amostras foi realizado de acordo com (HASUI; HIRABAYASHI; KOBAYASHI, 1989), da seguinte maneira:

Após o sacrifício dos animais por decaptação, o sangue foi coletado; uma bateria de 5 tubos foi, então, montada e numerada de "A" até "E" para cada animal. Cada tubo (de acordo com a letra) recebeu uma substância diferente, obedecendo-se sempre a uma mesma ordem como ilustra a figura 6.

Figura 6- Representação esquemática da seqüência de reagentes utilizados nas técnicas de burst oxidativo e fagocitose

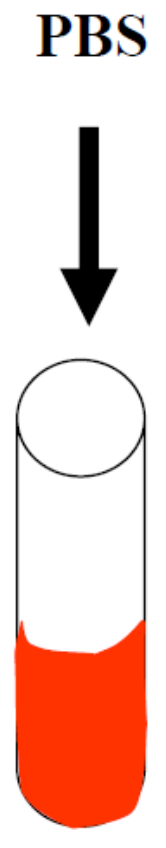

A

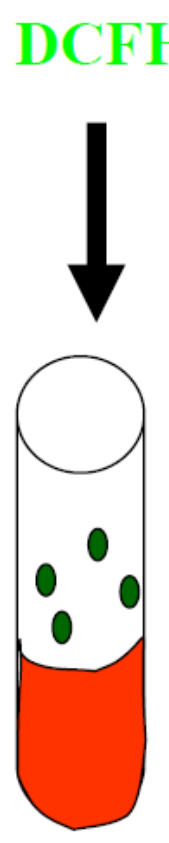

B

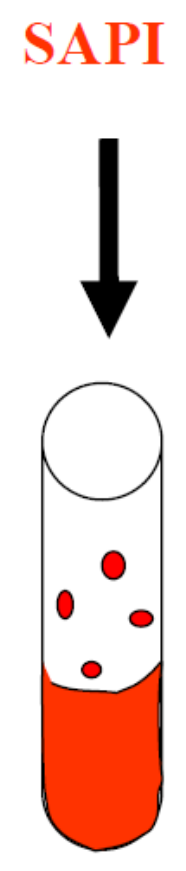

C
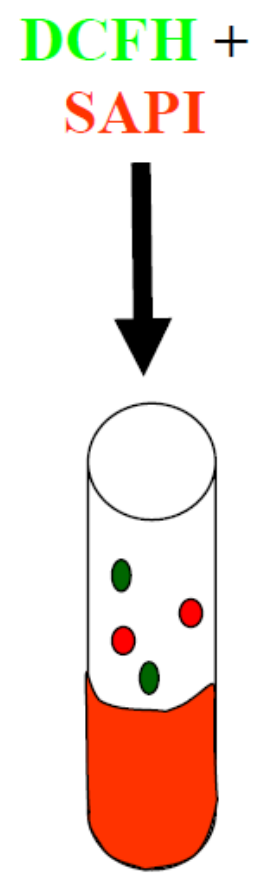

D
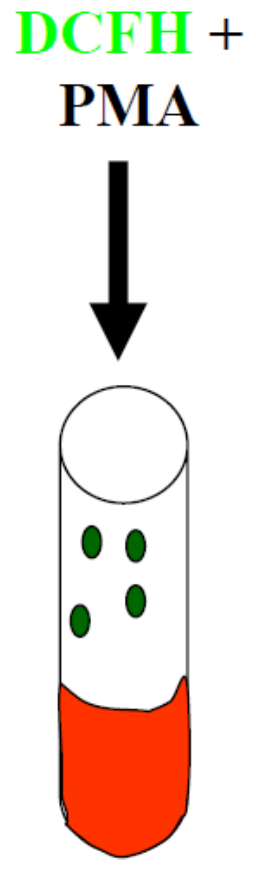

$\mathbf{E}$

Fonte: (ALVES, G. J., 2006)

Legenda: Tubo A= PBS; Tubo B= DCFH; Tubo C= SAPI; Tubo D= DCFH+SAPI e Tubo E= DCFH+PMA.

Desta forma, todos os tubos de "A" a "E" receberam alíquotas, que corresponderam a $2 \times 10^{5}$ cel $/ 100 \mu 1$ de sangue. Os tubos com as letras "B", "D" e "E" receberam $200 \mu 1$ da 
solução de DCFH-DA 3 mM cada. Todos os tubos de letra "C" e "D" receberam $100 \mu 1$ da solução de SAPI (100ng). Os tubos de letra "E", por sua vez, receberam 100 $\mu 1$ de PMA (100ng).

Como as amostras deveriam ter o volume final de $1100 \mu \mathrm{l}$, todos os tubos foram completados com PBS 1x. Sendo assim, todos os tubos "A" receberam $1000 \mu 1$ de PBS, os tubos "B" $800 \mu 1$, os "C" $900 \mu 1$ e finalmente os tubos "D" e "E" receberam $700 \mu 1$. Em seguida, os tubos foram incubados em banho-maria sob agitação a $37^{\circ} \mathrm{C}$ por 30 minutos. Depois da incubação, foram adicionados $2 \mathrm{ml}$ de EDTA $3 \mathrm{mM}$ em todos os tubos para interromper a reação, sendo os mesmos centrifugados posteriormente a $1200 \mathrm{rpm}$ por 10 minutos.

O sobrenadante foi desprezado após a centrifugação; as células foram, então, ressuspensas por agitação manual, realizando-se a seguir a lise hipotônica das amostras com soluções de $\mathrm{NaCl}$ a $0,2 \%$ e $1,6 \%$. Primeiramente, foi colocado em cada tubo $2 \mathrm{ml}$ de $\mathrm{NaCl}$ $0,2 \%$ durante 20 segundos. Imediatamente após este período, foi colocado mais $2 \mathrm{ml}$ de $\mathrm{NaCl}$ 1,6\% para tornar a solução isotônica novamente. Após centrifugação foram realizadas novas lises hipotônicas (uma segunda vez) com $\mathrm{NaCl}$ 0,2\% e após, com $\mathrm{NaCl}$ 1,6\%, seguindo-se todo o procedimento descrito acima. Após esta segunda lise, os tubos foram centrifugados pela última vez sendo o sobrenadante desprezado; as células resultantes foram ressuspensas em $1 \mathrm{ml}$ de EDTA gelado.

Após todo este procedimento, a leitura das amostras foi realizada no citômetro de fluxo; os tubos "A", "C" e "D" foram utilizados para a avaliação da Fagocitose, enquanto que os tubos "B" e "E" foram utilizados na avaliação do Burst Oxidativo. Cada amostra passou pelo citômetro apenas $1 \mathrm{vez}$, e de cada uma, foi adquirida 10.000 eventos (células). A fluorescência foi obtida padronizando-se o número de eventos para cada tubo A, B, C, D e E. Os valores referentes ao Burst oxidativo das amostras foram avaliados por meio da média geométrica da intensidade de fluorescência emitida pela população de neutrófilos. Este valor de média geométrica foi fornecido pelo aparelho sendo utilizado para indicar a intensidade de fluorescência das células.

Com relação à atividade fagocítica, foi verificada a porcentagem de fagocitose, ou seja, o número de neutrófilos que fagocitaram o $S$. aureus marcado com PI e, conseqüentemente que emitam fluorescência verde, divididos pelo número total destas células multiplicadas por 100 . 
Foi avaliada, também, a intensidade de fagocitose (quantidade de bactérias fagocitadas) por meio da média geométrica da intensidade de fluorescência vermelha emitida pelos neutrófilos.

\subsection{AVALIAÇÃO DO CRESCIMENTO DO TUMOR DE ERHLICH}

Para avaliação do crescimento do Tumor Ascítico de Ehrlich os camundongos foram eutanasiados em câmara de $\mathrm{CO}_{2}$ ao final de 11 dias da inoculação do tumor. Desses animais foi coletado o líquido ascítico para mensuração do volume e do número de células tumorais totais nele presentes e também a concentração (células tumorais/ml de fluído ascítico). A figura 7 ilustra este procedimento experimental:

Figura 7- Esquema ilustrativo da formação dos grupos experimentais dos experimentos em que se avaliou o crescimento tumoral em camundongos machos companheiros

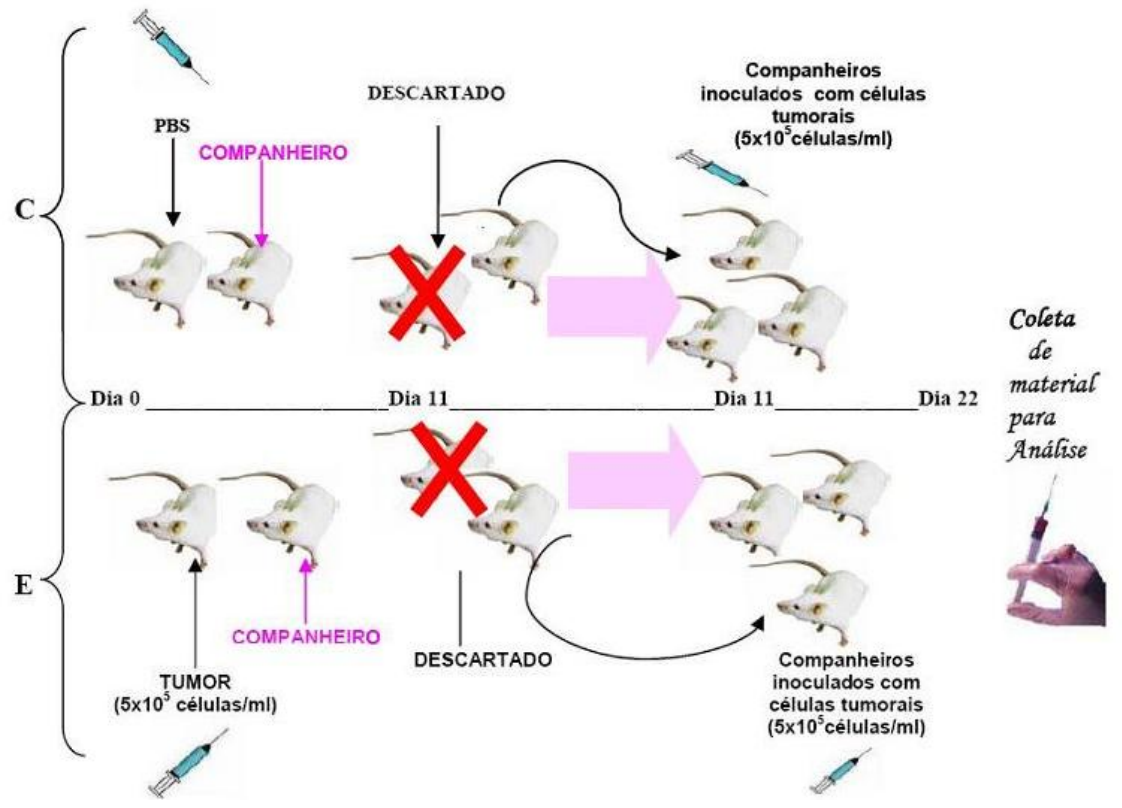

Fonte: (ALVES, G. J., 2006 adaptado por MACHADO, T. R. M., 2013). 


\subsection{COMPORTAMENTO EM CAMPO ABERTO}

\section{a) Campo aberto}

O campo aberto foi utilizado para medir a atividade geral dos animais. Trata-se de uma arena circular de madeira medindo $40,0 \mathrm{~cm}$ de diâmetro e 40,0 $\mathrm{cm}$ de altura pintada na cor cinza grafite. $\mathrm{O}$ fundo da arena circular é dividido, virtualmente, por 2 círculos concêntricos: zona central e periférica.

A medida de atividade dos animais no campo aberto foi feita por intermédio de um sistema indireto, EthoVision ${ }^{\circledR}$ (Noldus Information Technology ${ }^{\circledR}$, Leesburg, VA, USA). Cada animal permaneceu individualmente na arena por 5 minutos, com a finalidade de evitar-se influência de odores, a arena foi limpa com uma solução aquosa de álcool a $5 \%$ imediatamente antes da introdução de cada animal.

Como indicativos da atividade no campo aberto foram registrados os seguintes parâmetros em cada zona do aparelho:

- distância total percorrida: corresponde à distância gasta pelo animal no ato de entrar sucessivamente com as quatro patas em uma das divisões (zonas) do piso da arena, locomovendo-se $(\mathrm{cm})$.

- tempo de permanência na periferia em segundos: quanto tempo em segundos o animal se movimentou na zona periférica;

- número de entradas na periferia: corresponde ao número de vezes em que o animal entra na zona periférica do campo aberto;

- tempo de permanência no centro: quanto tempo em segundos o animal se movimentou na zona central;

- número de entradas no centro: corresponde ao número de vezes em que o animal entra na zona central do campo aberto;

- tempo de imobilidade: quanto tempo em segundos, o animal apresentou-se imóvel no interior das zonas do campo aberto (s);

- número de movimentos iniciados: corresponde ao número de vezes em que o animal inicia movimentos na arena;

- velocidade média: velocidade média percorrida pelo animal dentro da arena $\mathrm{em} \mathrm{cm} / \mathrm{s}$.

- tempo em movimento: quanto tempo em segundos, o animal se movimentou no interior das zonas do campo aberto(s). 


\section{b) Sistema de observação computadorizada-EthoVision ${ }^{\circledR}$}

Para as análises comportamentais, foi utilizado o aparelho EthoVision ${ }^{\circledR}$ (Noldus Information Technology ${ }^{\circledR}$, Leesburg, VA, USA) que consiste em um sistema de rastreamento em vídeo, análise de movimento e reconhecimento comportamental. O sistema é composto pelo programa Etho Vision Pro-Color 2.3 e pelos itens de "hardware": câmera filmadora (CCD-Iris color Sony, New York, PA, USA), monitor de vídeo (Sony, New York, PA, USA), computador (Pentium 133, $16 \mathrm{MB}$ de memória RAM, 1,2 gB de disco rígido) com placa de captura de vídeo (TARGA+Truevision, 2D NTSC), monitor SVGA, teclado e mouse, além de cabos e conectores. A figura 8 mostra este sistema.

Figura 8- EthoVision ${ }^{\circledR}$-(Vídeo Tracking Motion \& Behavior Recognition System Versão 2.3)- equipamento de rastreamento em vídeo, usado no procedimento experimental para análise de movimentos

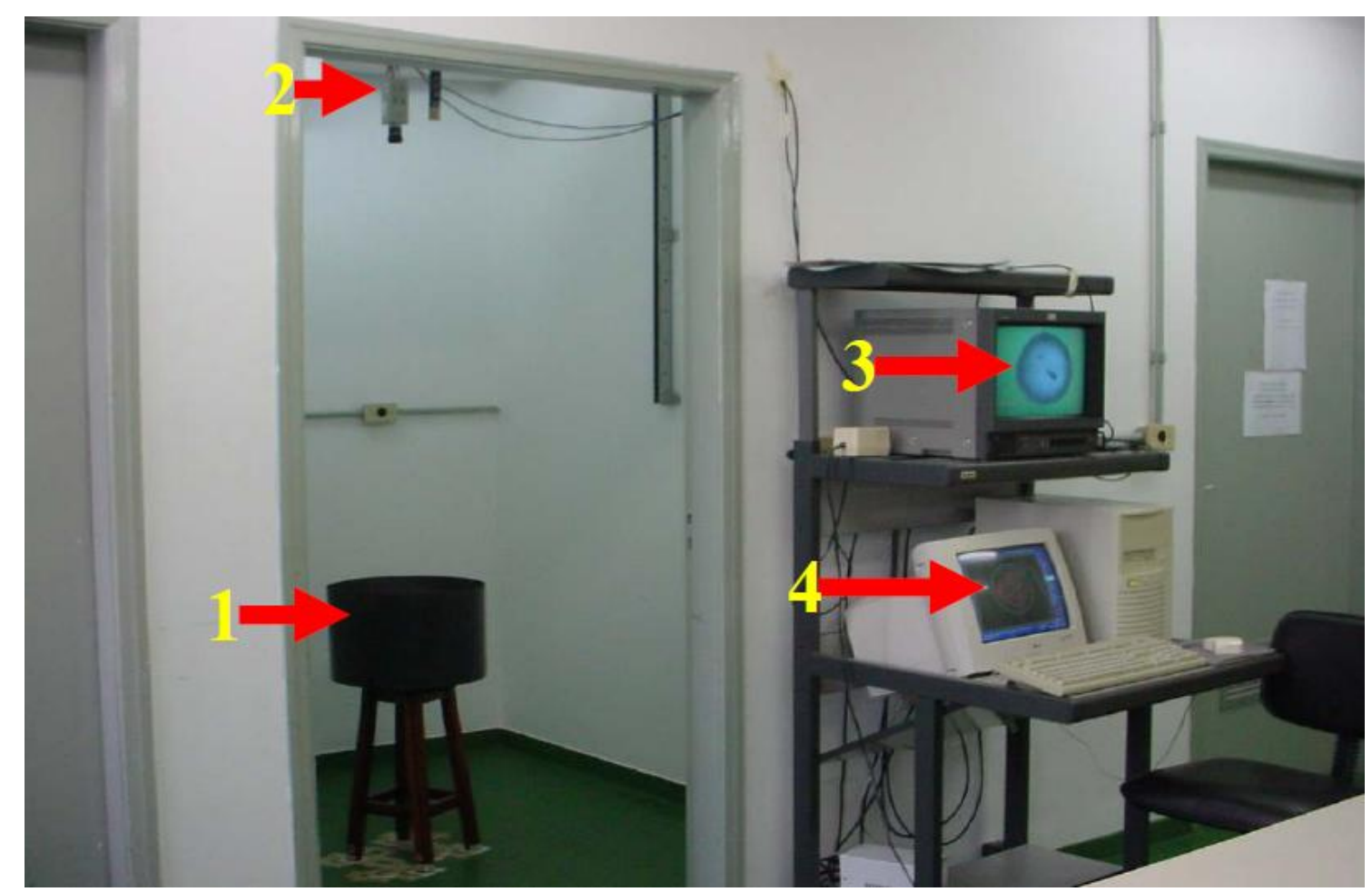

Fonte: (ALVES, G. J., 2006)

Legenda: As setas indicam: 1- Campo Aberto para camundongos, 2- Câmera filmadora acoplada ao computador, 3- Monitor de Vídeo e 4- Imagem digitalizada representada em pixels.

\section{c) Rastreamento do animal e análise do movimento}

A partir de imagens recebidas pela câmera filmadora e digitalizadas na placa de captura, o programa gera coordenadas (x e y) provenientes do centro de gravidade do animal, em intervalos de tempo determinados, obedecendo-se a uma taxa de amostragem de 6,66 
amostras por segundo. As coordenadas são geradas pelo método de subtração-ideal para rastrear um animal branco em uma arena cinza, no qual o sistema subtrai a imagem de cada amostra dos pontos da imagem de referência (imagem do campo aberto, vazio, isto é sem o animal, e captada antes do experimento).

Para que o sistema reconhecesse em qual zona do aparelho se encontra o animal, foi necessário fazer uma representação gráfica do campo aberto. Assim, sobrepondo-se a imagem do campo aberto vazio, no monitor de vídeo, ao canal de edição de imagem do programa, foi possível desenhar o contorno e as subdivisões de cada arena. Antes do início dos experimentos foi necessário configurar o limiar de ruído- diferença mínima de intensidade entre o fundo (background) e o animal- a fim de ignorar possíveis ruídos no sinal de vídeo durante o processamento subseqüente de imagens. Esse ajuste depende da intensidade de iluminação da arena e é feito automaticamente. A iluminação da sala durante as observações foi do tipo difusa, obtida colocando-se uma placa semi-opaca de acrílico branco abaixo da fonte luminosa, a fim de espalhar a luz uniformemente em todas as direções e minimizar o aparecimento de reflexos e sombras. Outro fator importante para eliminar os reflexos foi o contraste perfeito entre a arena e o animal, fato alcançado pintando-se as superfícies do campo aberto de cor cinza grafite.

Uma vez que a imagem digitalizada é representada em pixels (picture elementselementos de imagem), para que as coordenadas do animal sejam, fielmente usadas para calcular seu deslocamento real em centímetros, foi necessário usar um procedimento de calibração da arena. A calibração simples usa dois pontos separados por uma distância conhecida em centímetros (uma régua, por exemplo). No entanto, por assumir uma relação linear entre as distâncias no mundo real e aquela da imagem digitalizada, esse método negligencia a distorção provocada pela lente da câmera, o que afetaria os valores dos parâmetros de deslocamento (por exemplo, a distância movida). Deste modo, foi usado o método de calibração avançado, no qual, sobre a imagem digitalizada de uma cartolina com pontos desenhados com distâncias entre si conhecidas, digitalizados 35 pontos correspondentes às coordenadas reais em centímetros, de modo tal que o sistema tenha condições de fazer uma representação homogênea das distâncias em toda a arena, isto é, tanto no centro como nas extremidades. 


\section{d) Compilação e análise dos dados}

Cada sessão de 5 minutos no campo aberto corresponde a uma trilha (track). A análise feita pelo EthoVision ${ }^{\circledR}$ consiste em processar os dados do conjunto de trilhas de um experimento, isto é, a partir do registro das coordenadas e do que ocorre em cada amostra, o sistema calculou os valores numéricos das características de distribuição escolhidas para cada parâmetro.

Os resultados foram "exportados" na forma de um arquivo "txt" (extensão de arquivo texto) que, ao ser aberto na planilha do programa Microsoft Excel, contendo nas colunas às informações relacionadas de cada parâmetro.

\subsection{DOSAGENS NEUROQUÍMICAS}

Os animais foram submetidos à eutanásia por decaptação, sendo os cérebros rapidamente retirados e lavados com solução salina gelada $\left(4^{\circ} \mathrm{C}\right)$. Imediatamente após, foram dissecados sobre uma placa de petri rodeada por gelo seco, formando-se assim, um microambiente o mais frio possível. O córtex frontal, o hipotálamo e o bulbo foram, então, retirados, pesados e congelados a $-80^{\circ} \mathrm{C}$ num tempo máximo de 3 minutos, onde permaneceram por no máximo 3 meses até as dosagens.

Antes das dosagens os tecidos cerebrais foram homogeneizados por sonicação (caneta sonicadora), durante 2 ou 3 minutos sobre uma cuba de gelo seco, com solução de ácido perclórico 0,1 M contendo 0,02\% de $\mathrm{Na}_{2} \mathrm{~S}_{2} \mathrm{O}_{5}$, EDTA dissódico e uma concentração conhecida de DHBA foi utilizado como padrão interno para as dosagens de monoaminas. $\mathrm{O}$ DHBA (3,4 diidroxibenzilamina) foi escolhido como padrão interno por ter as mesmas características físico-químicas que as monoaminas dosadas.

Dopamina (DA), seus metabólitos ácido homovanílico (HVA) e ácido 4,4diidroxifenilacético (DOPAC); serotonina (5-HT) e seu metabólito ácido 5-hidroindol, 3acético (5HIAA); noradrenalina (NOR) e seu metabólito ácido vanilmandélico (VMA). Foram dosadas por Cromatografia Líquida de Alta Eficiência (HPLC), com detector eletroquímico. Foram calculadas também as relações DOPAC/DA, HVA/DA, HVA+DOPAC/DA; 5HIAA/5-HT; VMA/NOR como indicadores da taxa de renovação (turnover) de DA, 5-HT e NOR respectivamente. 
Após a homogeneização, as amostras foram colocadas na geladeira onde permaneceram por uma noite; no dia seguinte foram centrifugadas a $10000 \mathrm{rpm}$ por 30 minutos. O sobrenadante foi transferido para outro eppendorf, sendo as amostras em seguida congeladas a $-80^{\circ} \mathrm{C}$, onde ficaram aguardando a leitura no aparelho.

As dosagens neuroquímicas foram realizadas a partir de método previamente descrito (FELICIO et al., 1996). Foi utilizado um cromatógrafo líquido de alta eficiência (HPLC) acoplado a um detector eletroquímico (HPLC-ED; Shimadzu Modelo 6A). O HPLC-ED é composto de um recipiente injetor (válvula) de $20 \mu \mathrm{l}$, bombas de fluxo A e B, um sistema controlador (monitoramento de fluxo, pressão e temperatura), uma coluna cromatográfica medindo 150 X 4,6 mm, diâmetro de partícula $\mu \mathrm{m}$ (Shimpak - ODS C 18) com filtro de linha, um detector eletroquímico e um integrador modulado Chromatopac. A técnica utilizada é a de cromatografia em fase reserva com pareamento iônico. Esta técnica fundamenta-se na cromatografia de partição ou absorção. As condições de trabalho foram as seguintes: temperatura $50^{\circ} \mathrm{C}$, tempo de obtenção dos picos: até 24 minutos.

O limite de detecção do método foi igual a $10 \mathrm{ng} / \mathrm{g}$ e o limite de quantificação igual a $20 \mathrm{ng} / \mathrm{g}$ de tecido cerebral para DA, DOPAC, HVA, 5-HT, 5-HIAA, NOR e VMA.O equipamento foi padronizado diariamente, no início e ao término do trabalho, com uma solução de trabalho de neurotransmissores, seus metabólitos e PI (DHBA) empregando-se como diluente uma solução de ácido perclórico, 0,1M, contendo EDTA e metabissulfito de sódio.

\subsection{NÍVES DE CITOCINAS (IFN- $\gamma$, IL-12, IL-10, IL-6 E TNF- $\alpha$ ) NO BAÇO NO $11^{\circ}$ DIA DE CONVIVÊNCIA COM O DOENTE}

Foi utilizado um protocolo (BJORK, 2001) no qual, os baços dos animais foram removidos cirurgicamente após anestesia e mantidos em solução de RPMI estéril e gelado. Este órgão foi, então, lavado três vezes em RPMI estéril e macerado. Após este processo, seguiu-se a lise de eritrócitos do baço, o que foi feito através de uma solução de Cloreto de Amônio $(0,16 \mathrm{M})$. Após contagem das células em câmara de Neubauer diluídas em solução de azul de tripan, estas foram ajustadas para serem plaqueadas em $1 \times 10^{6}$ células por poço com 
$1 \mu \mathrm{g} / \mathrm{ml}$ de LPS por um período de 12 e 24 horas de encubação em estufa (37, $5 \%$ CO2) para a coleta de sobrenadante e análise das citocinas.

Para a análise das citocinas foi utilizado o Kit BD Cytometric Bead Array Mouse Inflamation ${ }^{\circledR}(\mathrm{CBA})$ (BD Biosciences, San Jose, CA, USA) para medir quantitativamente TNF- $\alpha$, IFN- $\Upsilon$, IL-6, IL-12 p70, IL-10 e MCP-1 em uma única amostra de plasma ou sobrenadante de cultura. O CBA pode ser comparado ao método de ELISA sanduíche; o protocolo de análise foi realizado de acordo com as instruções do fabricante (http://www.bdbiosciences.com/external_files/pm/doc/manuals/live/web_enabled/23-1272001.pdf).

De forma resumida, os nanobeads de captura, de detecção e as citocinas recombinantes da curva padrão específicas para cada citocina foram diluídas nas concentrações recomendadas. Cada nanobead está ligado a anticorpos específicos para a citocina/quimiocina a ser quantificada e apresenta tamanhos diferentes, o que permite a diferenciação de cada citocina, em diferentes picos de intensidade de fluorescência, como ilustra a figura 9.

Os reagentes foram adicionados aos tubos de citometria relativos aos padrões e às amostras na seguinte ordem: suspensão de nanobeads de captura $(50 \mu \mathrm{L})$, padrões nas diferentes diluições e amostras $(50 \mu \mathrm{L})$ e os nanobeads de detecção $(50 \mu \mathrm{L})$; essa mistura ficou sob incubação por 2 horas em temperatura ambiente no escuro. Após o período de incubação os tubos contendo os padrões e as amostras foram centrifugados a $250 \mathrm{x}$ g por 5 minutos sendo estes, lavados, centrifugados novamente e ressupensos para leitura no citômetro de fluxo, e determinação da intensidade de fluorescência de PE (detector FL3). A tabela 1 mostra os limites de detecção das citocinas em pg/ml. 
Figura 9- (A) Citograma que ilustra as populações de nanobeads da curva padrão para as diferentes citocinas na concentração de $625 \mathrm{pg} / \mathrm{mL}$. (B) Histograma que ilustra os picos de intensidade de fluorescência para as diferentes populações de nanobeads
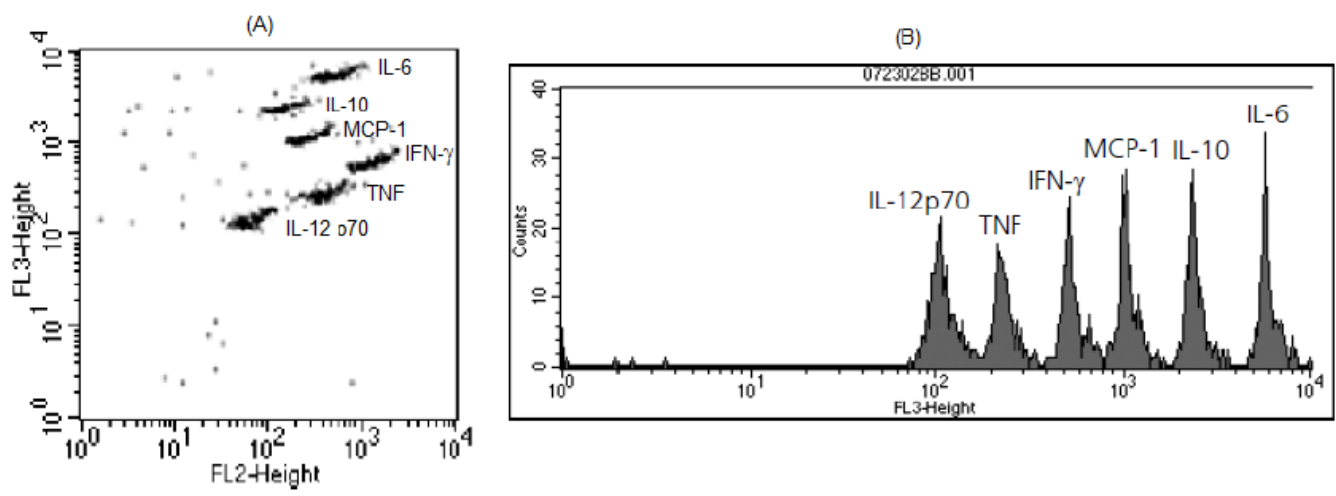

Fonte: Figura adaptada do manual do usuário do CBA mouse inflammation kit - BD Biosciences por Alves, G. J., 2006

Tabela 1- Limites de detecção das citocinas em pg/ml

\begin{tabular}{|c|c|}
\hline Citocina & $\begin{array}{c}\text { Limite de detecção } \\
(\mathbf{p g} / \mathbf{m l})\end{array}$ \\
\hline IL-2 & 0.1 \\
\hline IL-4 & 0.03 \\
\hline IL-6 & 1.4 \\
\hline IFN- $\gamma$ & 0.5 \\
\hline TNF & 0.9 \\
\hline IL-17 & 0.8 \\
\hline IL-10 & 16.8 \\
\hline
\end{tabular}


4.12 ANÁLISE DE EXPRESSÃO GÊNICA DE CITOCINAS (IL-1B, IL-6 E TNF- $\alpha$ ) NO HIPOTÁLAMO E CÓRTEX FRONTAL NO $11^{\circ}$ DIA DE CONVIVÊNCIA COM O DOENTE

\subsubsection{EXTRAÇÃO DE RNA}

A extração de RNA do tecido nervoso foi realizado com o kit para extração de RNA RNAspin Mini RNA Isolation Kit (GE Healthcare UK Limited Amersham Place; Little Chalfont, Buckinghamshire HP7 9NA, UK). Cerca de 6-20 mg de tecido nervoso (hipotálamo e córtex) foi adicionado em $350 \mu \mathrm{L}$ da solução de lise RA1 do kit, acrescido de 3,5 $\mu \mathrm{L}$ de Bmercaptoetanol, sendo macerado com a ajuda de um pistilo autoclavado e RNAse-free. A partir deste momento, a mistura foi transferida para colunas de extração, seguindo-se o protocolo determinado pelo fabricante do kit de extração. O processo consistiu basicamente em colocar as células em pequenas colunas de extração (adaptáveis a um eppendorff de 1,5 $\mathrm{mL}$ ), estas reteram o RNA enquanto o mesmo foi lavado e purificado com uma sequiência de reagentes. Na etapa final o reagente promoveu a liberação do RNA da coluna, o qual foi mantido em freezer $-80^{\circ} \mathrm{C}$ até o momento do uso.

\subsubsection{QUANTIFICAÇÃO E DETERMINAÇÃO DA INTEGRIDADE DO RNA TOTAL}

Uma alíquota de $10 \mu \mathrm{L}$ foi retirada para quantificação e verificação da integridade do RNA. O restante foi armazenado imediatamente em freezer $-80^{\circ} \mathrm{C}$ até sua utilização. A análise qualitativa foi realizada submetendo-se as amostras a eletroforese em gel de agarose 1,5\% diluída em TAE $1 \mathrm{X}$ (48,4g de Tris base; 20mL de EDTA 0,5M, pH 8,0;1L,4mL de Ácido Acético; H2O MilliQ autoclavada q.s.p. 1000mL), 60V, por 1,5 hora. Após a eletroforese, o gel foi corado em solução de brometo de etídio $(0,5 \mathrm{mg} / \mathrm{mL}$ em H2O destilada) para a visualização das bandas $28 \mathrm{~S}$ e $18 \mathrm{~S}$ em luz UV. A correta identificação destas bandas indica a qualidade do RNA. A quantificação foi realizada pelo NanoDrop 2000 (Thermo Scientific) $(260 / 280 \mathrm{~nm})$. Amostras numa variação de 1,7 até $2,0 \mathrm{ng} / \mu \mathrm{L}$ indicam baixa 
contaminação do RNA, sendo consideradas de boa qualidade para a transcrição reversa.

\subsubsection{TRANSCRIÇÃO REVERSA}

Para eliminar quaisquer resquícios de DNA, o RNA total foi tratado com DNAse I. Foi utilizado $1 \mu \mathrm{l}$ de DNAse I para tratar $4 \mu \mathrm{g} / \mu \mathrm{l}$ de RNAtotal. Os eppendorfs foram mantidos à temperatura ambiente por 15 minutos, sendo adicionados $1 \mu \mathrm{l}$ de EDTA $(25 \mathrm{mM})$ para bloquear a ação da enzima e aquecidos por 10 minutos a $65^{\circ} \mathrm{C}$ em banho seco seguido de resfriamento em banho de gelo. As amostras receberam $1 \mu \mathrm{L}$ de Oligo DT; $1 \mu \mathrm{L}$ de dNTPs (mix $10 \mathrm{mM}-2,5 \mathrm{mM}$ de cada dNTP) e posteriormente foram incubadas a $65^{\circ} \mathrm{C}$ por 5 minutos e resfriadas em gelo. Ainda no gelo foram adicionados a cada tudo $4 \mu \mathrm{L}$ do buffer $5 \mathrm{X}$ (superscript II); $2 \mu \mathrm{l}$ de DTT 1M; $1 \mu \mathrm{L}$ de RNAse OUT incubando-se por 2 minutos a $42^{\circ} \mathrm{C}$ e resfriadas no gelo. Foi acrescido $1 \mu \mathrm{Lda}$ enzima de transcrição reversa superscript II, permanecendo em incubação a $42^{\circ} \mathrm{C}$, por 50 minutos e em seguida por $70^{\circ} \mathrm{C}$ por 15 minutos e resfriados no gelo. Em seguida foi acrescido $1 \mu \mathrm{L}$ da enzima RNAse $H$ (para eliminação de resíduos de RNA da amostra de cDNA), permanecendo por 20 minutos a $37^{\circ} \mathrm{C}$. O cDNA foi armazenado a $-20^{\circ} \mathrm{C}$ até o momento da amplificação do cDNA. Todos os reagentes foram fornecidos pela Invitrogen Life Technologies (Life Technologies, California, USA).

\subsubsection{QUANTIFICAÇÃO DA EXPRESSÃO GÊNICA POR PCR EM TEMPO REAL}

A análise por PCR em tempo real foi realizada em sistema de detecção StepOnePlus Real Time PCR Systems (Applied Biosystems, USA). Para avaliação da expressão foram colocados em tubos apropriados (Optical Tubes Applied Biosystems) $2 \mu \mathrm{L}$ de cada produto de PCR (cerca de 10ng de RNA total), tampão A TaqMan 1X, $\mathrm{MgCl} 2$ 5,5 mM, $200 \mathrm{nM}$ de dATP/dCTP/dGTP, 400vM dUTP, $200 \mathrm{nM}$ dos primers (senso e antisenso), $100 \mathrm{nM}$ das probes TaqMan, 0,01U/mL de AmpErase e $0.025 \mathrm{U} / \mu \mathrm{l}$ da DNA polimerase AmpliTaq Gold em um volume total de $50 \mu \mathrm{L}$. Após a completa mistura dos reagentes cada tubo foi fechado com tampas MicroAmp Optical (Applied Biosystems). Todas as reações foram corridas em 
duplicata. As condições de amplificação utilizadas para quase todos os genes foram: 2 minutos a $50^{\circ} \mathrm{C}, 10$ minutos à $95^{\circ} \mathrm{C}$; seguidos de 50 ciclos a $90^{\circ} \mathrm{C}$ por 15 segundos para desnaturação da fita de cDNA e a $60^{\circ} \mathrm{C}$ por 1 minuto para sua extensão. A interpretação dos resultados foi realizada conforme descrito pelo método comparativo de Livak e Schmittgen (2001) onde a expressão relativa dos genes corresponde a 2- $\Delta \Delta \mathrm{Ct}$.

\subsubsection{ASSAYS (PRIMERS)}

Todos os assays (primers) foram adquiridos da empresa Applied Biosystems, e seus respectivos IDs estão descritos no quadro 1.

Quadro 1- Assays da empresa Applied Biosystems utilizados para análise da expressão gênica por PCR em tempo real

\begin{tabular}{|l|l|}
\hline GENES & ASSAY ID \\
\hline IL-1B & Mm99999061_mH \\
\hline IL-6 & Mm00446191_m1 \\
\hline TNF-Alfa & Mm00443258_m1 \\
\hline 18 S (Controle endógeno) & $4352930 \mathrm{E}$ \\
\hline
\end{tabular}

\subsection{ANÁLISE ESTATÍSTICA}

Os dados paramétricos foram analisados pelo teste "t" de Student com correção de Welth ou pela ANOVA de duas vias seguida do teste de Turkey-Kramer para avaliação dos contrastes. Os resultados não paramétricos foram analisados pelo teste "U" de Mann Whitney. Foram consideradas significantes todas as análises que revelaram nível de significância $\mathrm{p} \leq 0,05$. 


\section{DELINEAMENTO EXPERIMENTAL E RESULTADOS}

\subsection{EXPERIMENTO 1- AVALIAÇÃO DOS NÍVEIS DE CORTICOSTERONA SÉRICA NO $5^{\circ}, 7^{\circ}, 9^{\circ} \mathrm{E} 11^{\circ}$ DIA DE CONVIVÊNCIA COM O DOENTE POR ELISA}

Conforme descrito no item 4.2., foram utilizados 30 camundongos os quais foram separados em pares, de acordo com o peso corporal em dois grupos: um grupo controle e um grupo experimental. No dia (0) do experimento um camundongo de cada par controle (CAS) foi inoculado com PBS i.p. e um camundongo de cada par experimental (CAD) foi inoculado com células do tumor de Ehrlich $\left(5 \times 10^{6}\right.$ céls/animal) i.p. No $5^{\circ}, 7^{\circ}, 9^{\circ}$ e $11^{\circ}$ dias de convivência, as amostras de sangue dos animais companheiros dos inoculados com PBS ou tumor de Ehrlich foram coletadas para a análise dos níveis séricos de corticosterona conforme descrito no item 4.4 .

\section{Resultados}

As figuras 10, 11, 12 e 13 ilustram os efeitos da convivência com camundongos portadores do tumor de Ehrlich respectivamente, durante o $5^{\circ}, 7^{\circ}, 9^{\circ}$ e $11^{\circ}$ dias sobre os níveis séricos de corticosterona. As figuras 14, 15, 16 e 17 representam estes valores em porcentagem (\%) dos níveis deste hormônio em relação ao grupo controle (100\%) também no $5^{\circ}, 7^{\circ}, 9^{\circ}$ e $11^{\circ}$ dias de convivência com o animal doente e a figura 18 representa a relação entre valores séricos de corticosterona com os grupos e dias (ANOVA de duas vias). Como se observa, não houveram alterações significantes nos níveis séricos deste hormônio entre os animais dos dois grupos $(\mathrm{p}>0,05)$. 
Figura 10- Níveis séricos de corticosterona no $5^{\circ}$ dia de convivência com portadores de umtumor ascítico de Ehrlich

\section{$5^{\circ} \mathrm{dia}$}

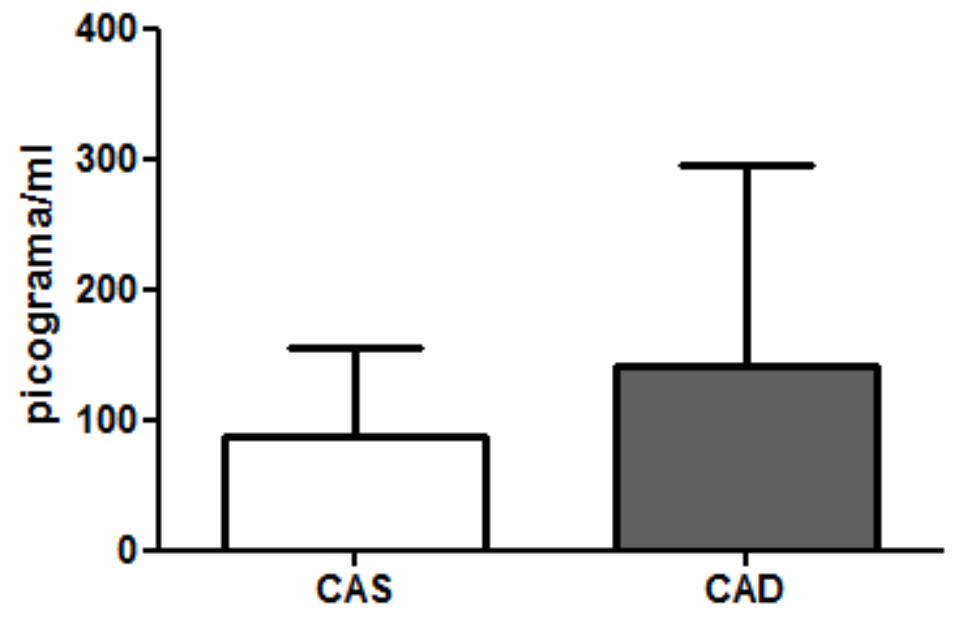

Corticosterona Sérica

Legenda: $\mathrm{CAS}=$ companheiros dos animais injetados com PBS; CAD= companheiros dos animais inoculados com o tumor ascítico de Ehrlich. Os dados representam a média \pm o desvio padrão de 7 animais por grupo, p>0,05 (teste Mann Whitney)

Figura 11- Níveis séricos de corticosterona no $7^{\circ}$ dia de convivência com portadores de um tumor ascítico de Ehrlich

\section{$7^{\circ}$ dia}

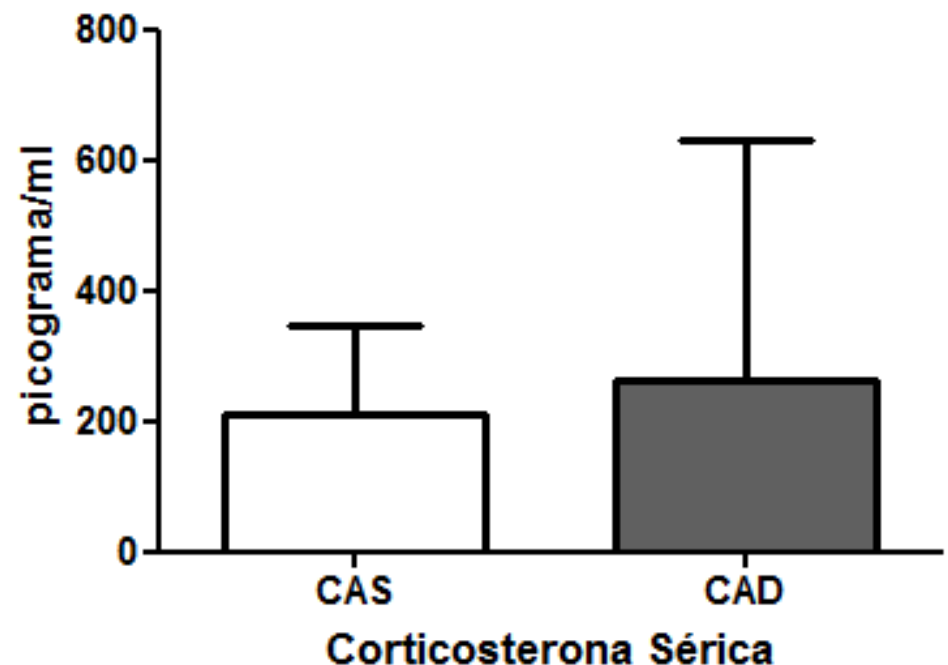

Legenda: $\mathrm{CAS}=$ companheiros dos animais injetados com PBS; CAD= companheiros dos animais inoculados com o tumor ascítico de Ehrlich. Os dados representam a média \pm o desvio padrão de 7 animais por grupo, p>0,05 (teste Mann Whitney) 
Figura 12- Níveis séricos de corticosterona no $9^{\circ}$ dia de convivência com portadores de um tumor ascítico de Ehrlich

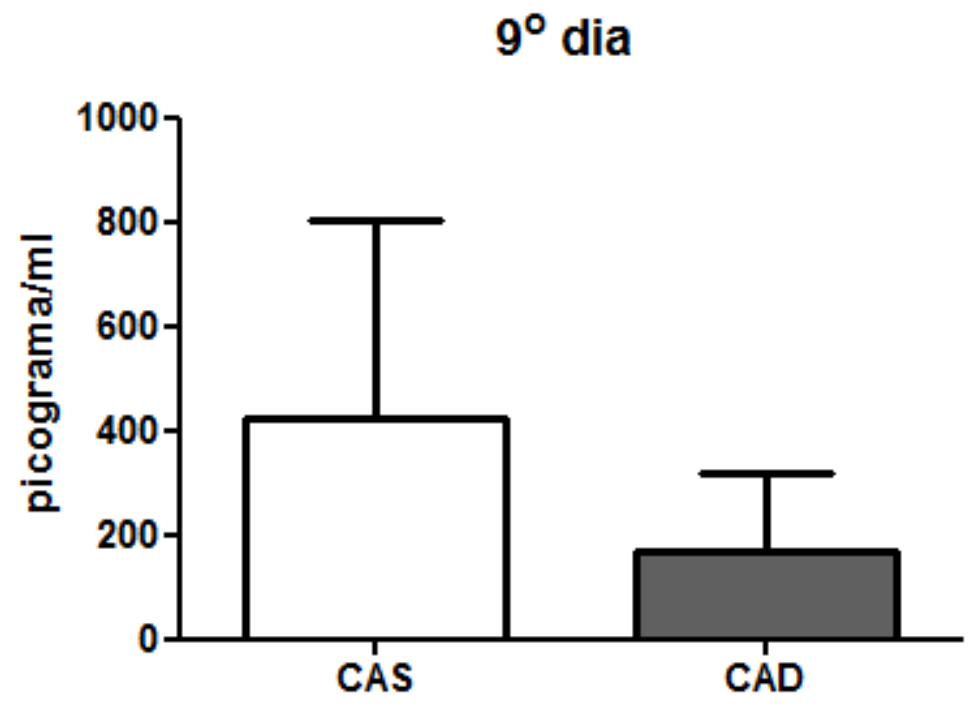

Corticosterona Sérica

Legenda: $\mathrm{CAS}=$ companheiros dos animais injetados com PBS; CAD= companheiros dos animais inoculados com o tumor ascítico de Ehrlich. Os dados representam a média \pm o desvio padrão de 7 animais por grupo, $\mathrm{p}>0,05$ (teste Mann Whitney)

Figura 13- Níveis séricos de corticosterona no $11^{\circ}$ dia de convivência com portadores de um tumor ascítico de Ehrlich.

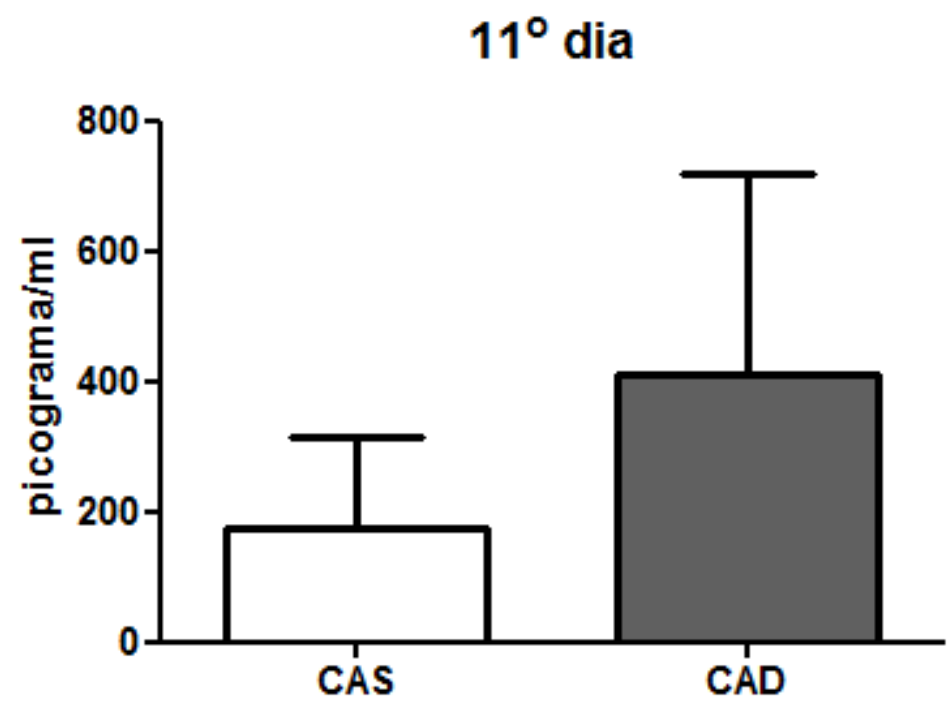

Corticosterona Sérica

Legenda: $\mathrm{CAS}=$ companheiros dos animais injetados com PBS; CAD= companheiros dos animais inoculados com o tumor ascítico de Ehrlich. Os dados representam a média \pm o desvio padrão de 7 animais por grupo, p>0,05 (teste Mann Whitney) 
Figura 14- Níveis séricos de corticosterona expressos em porcentagem (\%) no $5^{\circ}$ dia de convivência com portadores de um tumor ascítico de Ehrlich

\section{$5^{\circ}$ dia}

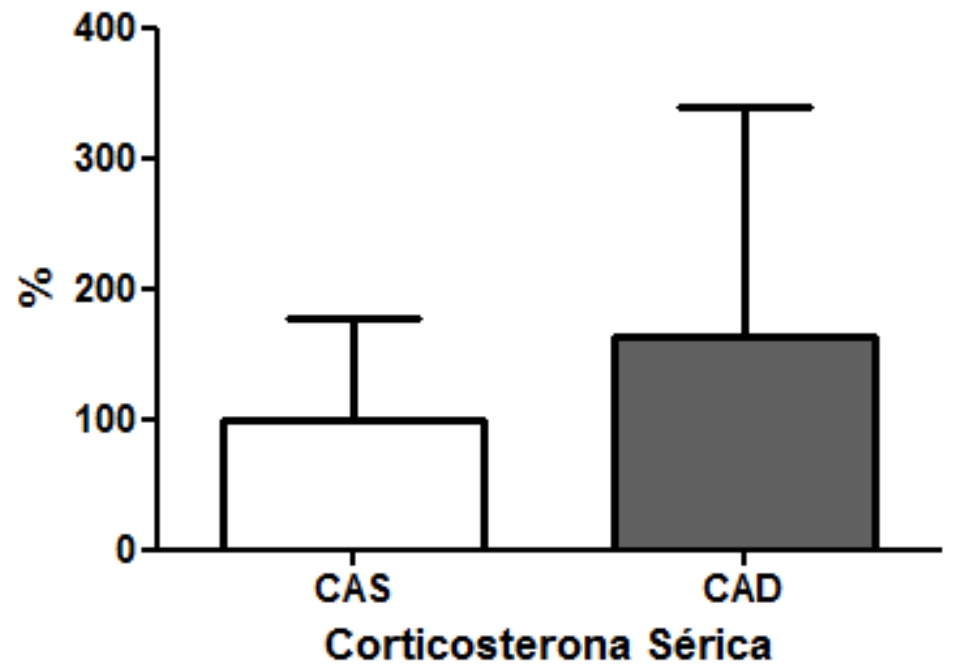

Legenda: $\mathrm{CAS}=$ companheiros dos animais injetados com PBS; CAD = companheiros dos animais inoculados com o tumor ascítico de Ehrlich. Os dados representam a média \pm o desvio padrão de 7 animais por grupo, $p>0,05$ (teste Mann Whitney)

Figura 15- Níveis séricos de corticosterona expressos em porcentagem (\%) no $7^{\circ}$ dia de convivência com portadores de um tumor ascítico de Ehrlich

\section{$7^{\circ}$ dia}

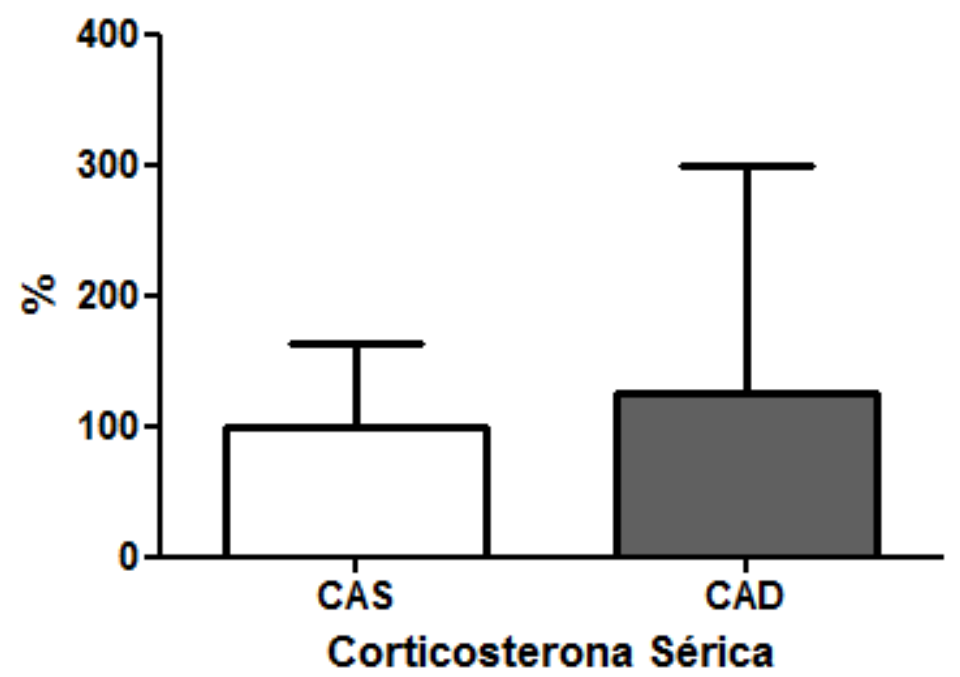

Legenda: $\mathrm{CAS}=$ companheiros dos animais injetados com PBS; $\mathrm{CAD}=$ companheiros dos animais inoculados com o tumor ascítico de Ehrlich. Os dados representam a média \pm o desvio padrão de 7 animais por grupo, $p>0,05$ (teste Mann Whitney) 
Figura 16- Níveis séricos de corticosterona expressos em porcentagem (\%) no $9^{\circ}$ dia de convivência com portadores de um tumor ascítico de Ehrlich

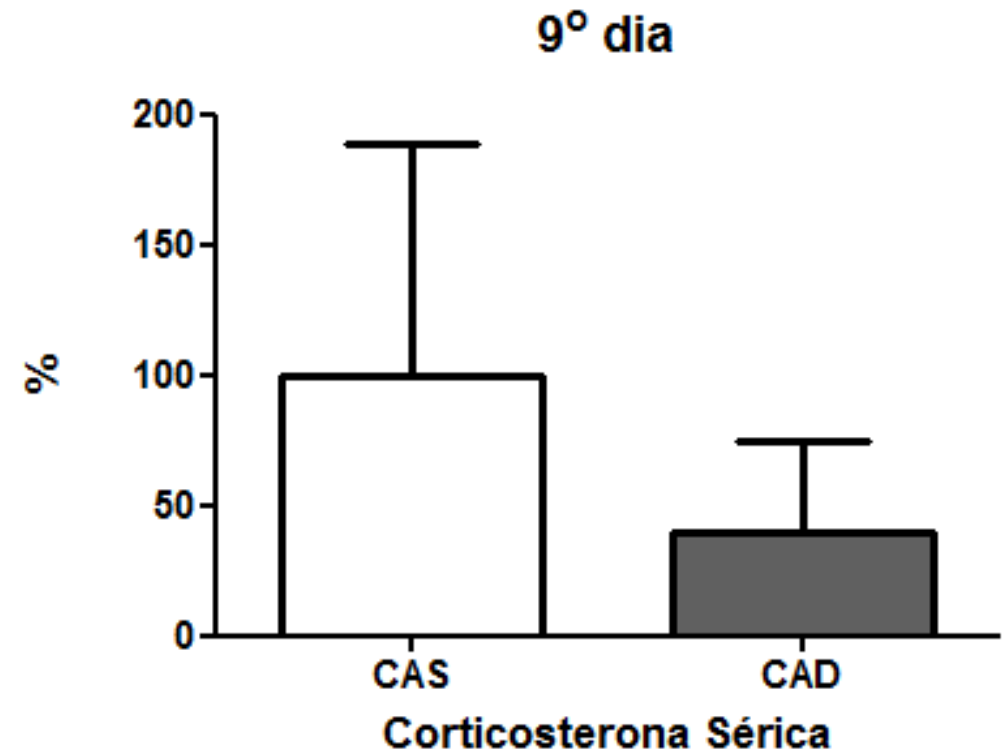

Legenda: $\mathrm{CAS}=$ companheiros dos animais injetados com PBS; CAD= companheiros dos animais inoculados com o tumor ascítico de Ehrlich. Os dados representam a média \pm o desvio padrão de 7 animais por grupo, p>0,05 (teste Mann Whitney)

Figura 17- Níveis séricos de corticosterona expressos em porcentagem (\%) no $11^{\circ}$ dia de convivência com portadores de um tumor ascítico de Ehrlich

\section{$11^{\circ} \mathrm{dia}$}

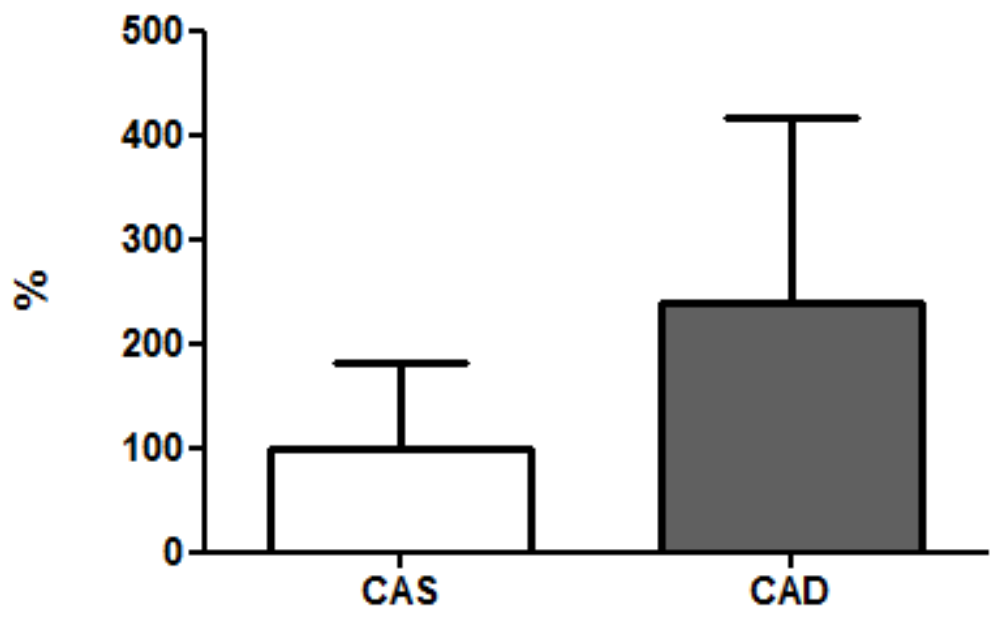

Corticosterona Sérica

Legenda: CAS = companheiros dos animais injetados com PBS; CAD= companheiros dos animais inoculados com o tumor ascítico de Ehrlich. Os dados representam a média \pm o desvio padrão de 7 animais por grupo, p>0,05 (teste Mann Whitney) 
Figura 18- Níveis séricos de corticosterona correlacionando os grupos e dias de convivência em $\mathrm{pg} / \mathrm{ml}$ no $5^{\circ}, 7^{\circ}$, $9^{\circ}$ e $11^{\circ}$ dias de convivência com portadores de um tumor ascítico de Ehrlich

\section{Corticosterona serica}

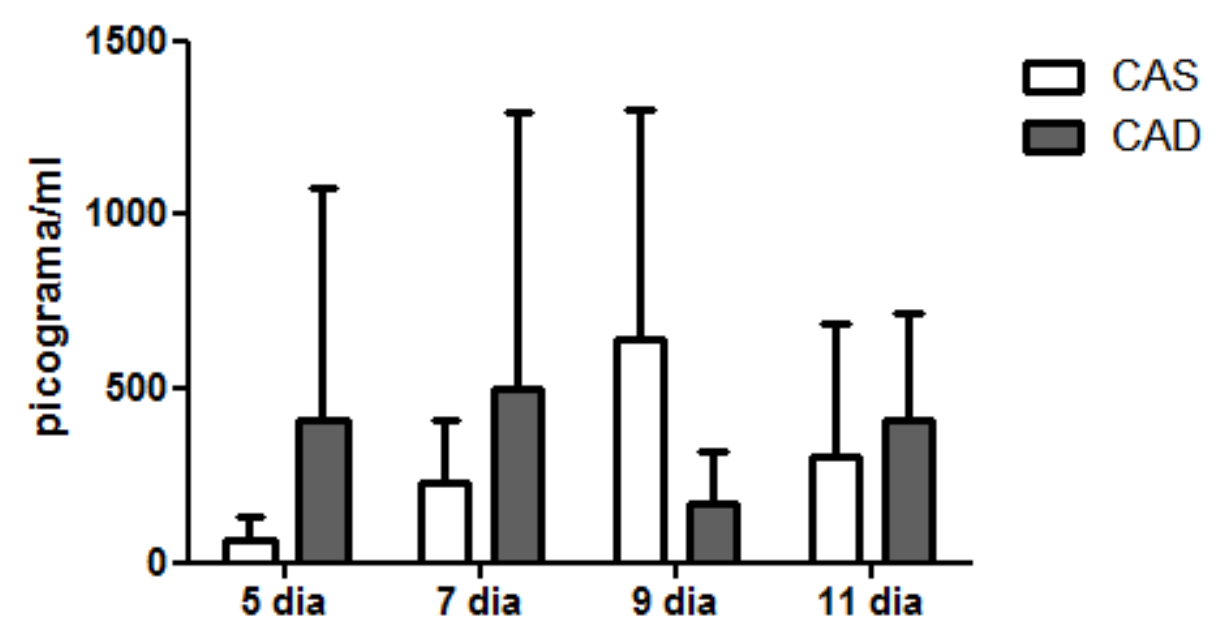

Legenda: CAS = companheiros dos animais injetados com PBS; CAD = companheiros dos animais inoculados com o tumor ascítico de Ehrlich. Os dados representam a média \pm o desvio padrão de 7 animais por grupo, $\mathrm{p}>0,05$ (ANOVA de duas vias)

\subsection{EXPERIMENTO 2- AVALIAÇÃO DO PESO RELATIVO DA GLÂNDULA ADRENAL}

Conforme descrito no item 4.2., foram utilizados 42 camundongos os quais foram separados em pares, de acordo com o peso corporal em dois grupos: um grupo controle e um grupo experimental. No dia (0) do experimento um camundongo de cada par controle foi inoculado com PBS i.p. e um camundongo de cada par experimental foi inoculado com células do tumor de Ehrlich $\left(5 \times 10^{6}\right.$ céls/animal) i.p. No $11^{\circ}$ dia de convivência, a glândula foi colhida dos animais companheiros inoculados com PBS (CAS) ou tumor de Ehrlich (CAD) para a pesagem do órgão conforme descrito no item 4.5.

\section{Resultados}

A figura 19 ilustra os efeitos da convivência por 11 dias com camundongos portadores do tumor de Ehrlich sobre o peso relativo da glândula adrenal. Não se verificaram alterações significantes nos dados analisados em ambos os grupos $(\mathrm{p}>0,05)$. 
Figura 19- Efeitos sobre o peso relativo da glândula adrenal no $11^{\circ}$ dia de convivência com portadores de um tumor ascítico de Ehrlich

\section{Peso Relativo}

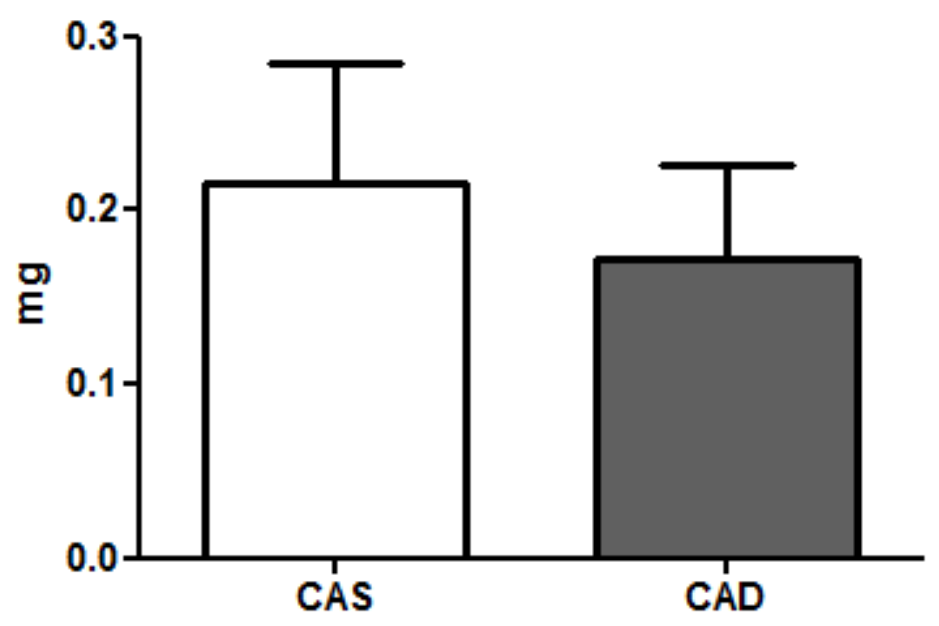

Legenda: $\mathrm{CAS}=$ companheiros dos animais injetados com PBS; CAD = companheiros dos animais inoculados com o tumor ascítico de Ehrlich. Os dados representam a média \pm o desvio padrão de 12 animais por grupo, $p>0,05$ (teste " $t$ " de Student)

\subsection{EXPERIMENTO 3- AVALIAÇÃO DOS NÍVEIS PLASMÁTICOS DE ADRENALINA E NORADRENALINA NO $11^{\circ}$ DIA DE CONVIVÊNCIA COM O DOENTE POR ELISA}

Conforme descrito no item 4.2., foram utilizados 32 camundongos os quais foram separados em pares, de acordo com o peso corporal em dois grupos: um grupo controle e um grupo experimental. No dia (0) do experimento um camundongo de cada par controle foi inoculado com PBS i.p. e um camundongo de cada par experimental foi inoculado com células do tumor de Ehrlich $\left(5 \times 10^{6}\right.$ céls/animal) i.p. No $11^{\circ}$ dia de convivência, a amostra de sangue dos animais companheiros dos inoculados com PBS (CAS) ou tumor de Ehrlich (CAD) foi coletada para a análise dos níveis plasmáticos de adrenalina e noradrenalina conforme descrito no item 4.6. 


\section{Resultados}

As figuras 20 e 21 ilustram os efeitos da convivência por 11 dias com camundongos portadores do tumor de Ehrlich sobre os níveis plasmáticos de adrenalina e noradrenalina respectivamente.

Como pode ser observado, a convivência com o animal portador do tumor ascítico de Ehrlich por 11 dias aumentou os níveis de adrenalina e noradrenalina plasmática nos animais CAD em relação aos animais do CAS ( $\mathrm{p} \leq 0,05)$.

Figura 20- Efeitos sobre o nível de adrenalina plasmática no $11^{\circ}$ dia de convivência com portadores de um tumor ascítico de Ehrlich

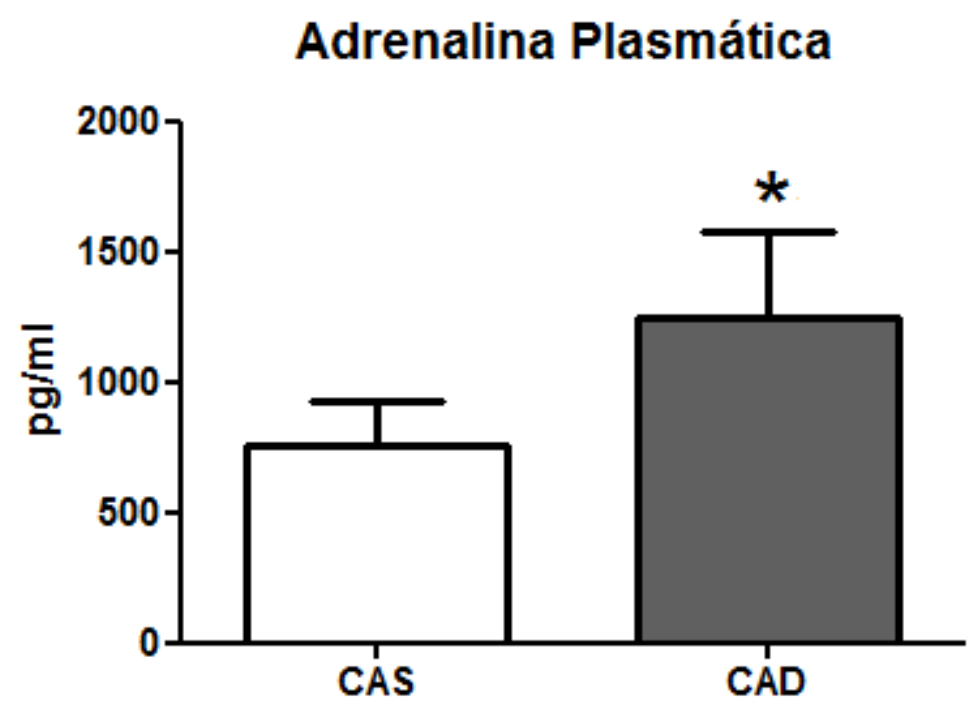

Legenda: $\mathrm{CAS}=$ companheiros dos animais injetados com PBS; $\mathrm{CAD}=$ companheiros dos animais inoculados com o tumor ascítico de Ehrlich. Os dados representam a média \pm o desvio padrão de 8 animais por grupo, $\mathrm{p} \leq 0,05$ (teste " $\mathrm{t}$ " de Student) 
Figura 21- Efeitos sobre o nível de noradrenalina plasmática no $11^{\circ}$ dia de convivência com portadores de um tumor ascítico de Ehrlich

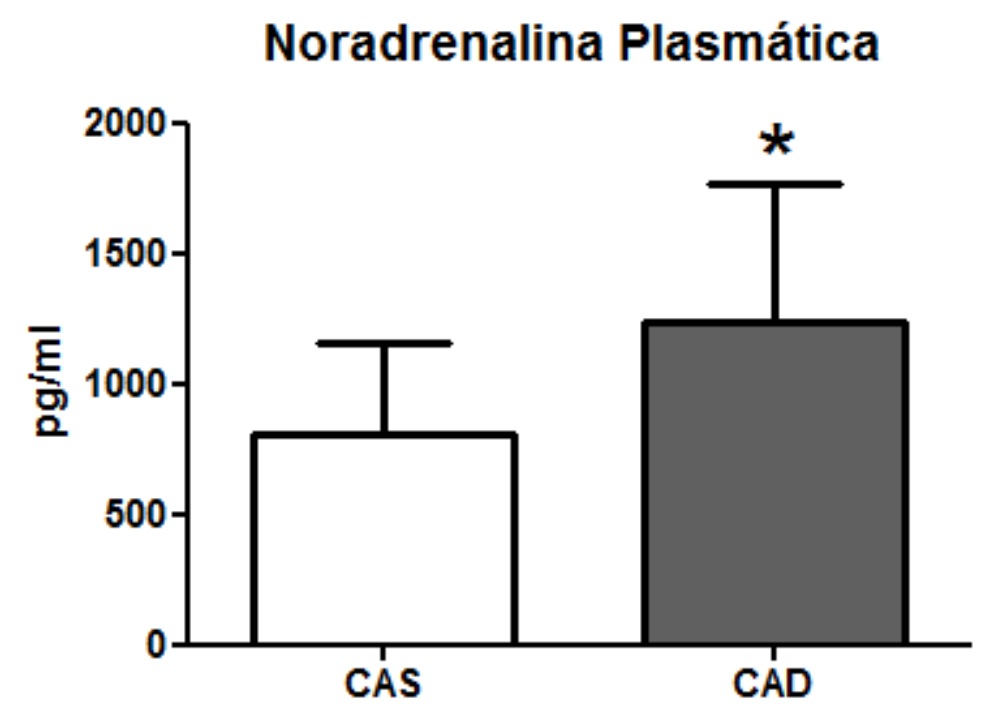

Legenda: $\mathrm{CAS}=$ companheiros dos animais injetados com PBS; CAD= companheiros dos animais inoculados com o tumor ascítico de Ehrlich. Os dados representam a média \pm o desvio padrão de 8 animais por grupo, $\mathrm{p} \leq 0,05$ (teste " $\mathrm{t}$ " de Student)

\subsection{EXPERIMENTO 4- AVALIAÇÃO DO BURST OXIDATIVO E FAGOCITOSE DE NEUTRÓFILOS NO $11^{\circ}$ DIA DE CONVIVÊNCIA COM O DOENTEPOR CITOMETRIA DE FLUXO}

Conforme descrito no item 4.2., foram utilizados 30 camundongos os quais foram separados em pares, de acordo com o peso corporal em dois grupos: um grupo controle e um grupo experimental. No dia (0) do experimento um camundongo de cada par controle foi inoculado com PBS i.p. e um camundongo de cada par experimental foi inoculado com células do tumor de Ehrlich $\left(5 \times 10^{6}\right.$ céls/animal) i.p. No $11^{\circ}$ dia de convivência, as amostras de sangue dos animais companheiros dos inoculados com PBS (CAS) ou tumor de Ehrlich (CAD) foram coletadas para a realização da determinação do burst oxidativo e fagocitose de neutrófilos como descrito no item 4.7. 


\section{Resultados}

Os citogramas que ilustram os dados relativos ao SSC vs FSC de leucócitos do sangue dos camundongos são apresentados a seguir (Figuras 22A, 23A, 24A e 25A) bem como os histogramas que ilustram a fluorescência destas células frente aos diferentes estímulos utilizados (Figuras 22B, 23B, 24B e 25B). Citogramas e histogramas semelhantes foram utilizados para a análise individual das populações celulares de neutrófilos do sangue periférico dos animais CAS e CAD. Estas populações foram identificadas ao microscópio óptico após uma separação mecânica realizada pelo FACSCALIBUR e a devida coloração pelo Giensa. Cada população celular teve uma pureza de aproximadamente $98 \%$; na figura 22A a população R1 corresponde aos neutrófilos, a R2 aos monócitos e a R3 aos linfócitos. Desta forma, os citogramas observados nas figuras $22 \mathrm{~A}$ à $25 \mathrm{~A}$ em diante correspondem ao burst oxidativo e à fagocitose destas populações celulares frente aos estímulos utilizados, ou seja, DCFH, PMA e S. aureus, respectivamente. As figuras 22B à 25B correspondem aos histogramas de fluorescência das populações de neutrófilos obtidas também frente aos estímulos utilizados, ou seja, DCFH, PMA e $S$. aureus respectivamente. A figura 26 ilustra os histogramas relacionados à análise da fagocitose (porcentagem e intensidade). Desta forma, a figura 26-1 representa o histograma do controle negativo, isto é, apenas neutrófilos em PBS. Como pode ser verificado na abscissa desta figura não existem células emitindo fluorescência acima de $10^{1}$ o que foi considerado como limite da técnica de citometria usada (M1). Na figura 26-2 observa-se a porcentagem de neutrófilos que realizaram fagocitose empregandose o mesmo limite (M1): especificamente, a fluorescência observada acima de $10^{1}$ corresponde aos neutrófilos que realizaram fagocitose emitida pelos neutrófilos que fagocitaram a $S$. aureus.

As populações de leucócitos sanguíneos observados no citômetro foram padronizadas da seguinte maneira: região $\mathrm{R} 1=$ linfócitos; região $\mathrm{R} 2=$ monócitos; região $\mathrm{R} 3=$ neutrófilos. 
Figura 22- Citograma dos leucócitos

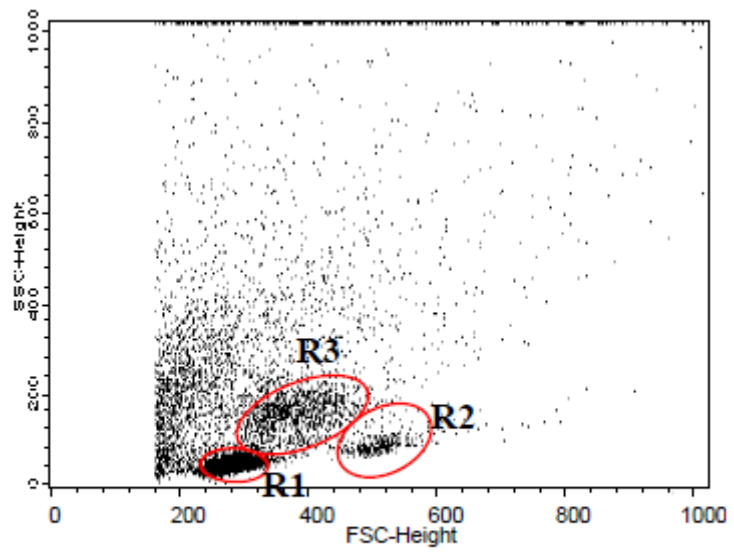

(A)

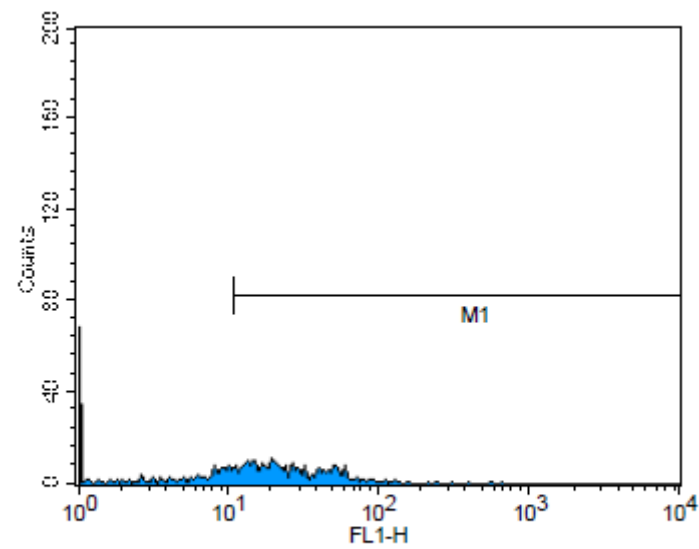

(B)

Fonte: (ALVES, G. J., 2006)

Legenda: (A) e Histograma (B) dos neutrófilos após a incubação com o DCFH de animais do grupo controle. $\mathrm{R} 1=$ linfócitos; $\mathrm{R} 2=$ monócitos; $\mathrm{R} 3=$ neutrófilos

Figura 23- Citograma dos leucócitos

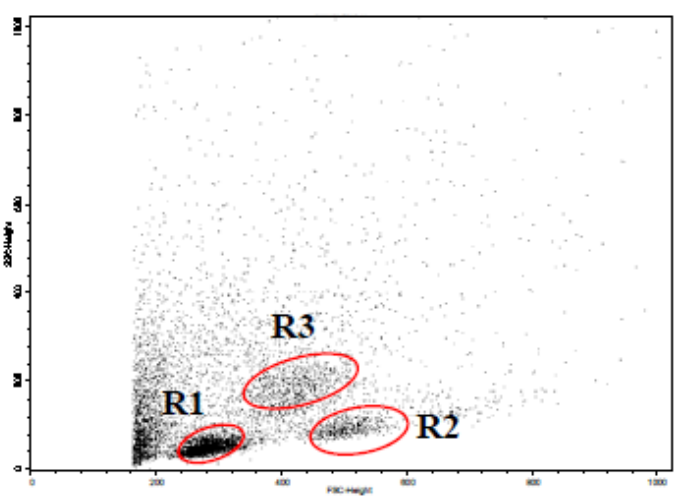

(A)

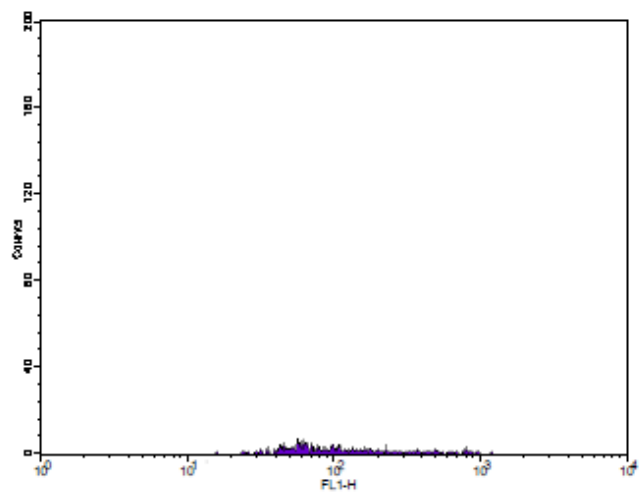

(B)

Fonte: (ALVES, G. J., 2006)

Legenda: (A) e Histograma (B) dos neutrófilos após a incubação com o PMA de animais do grupo controle. R1=linfócitos; R2=monócitos; R3=neutrófilos 
Figura 24- Citograma dos leucócitos

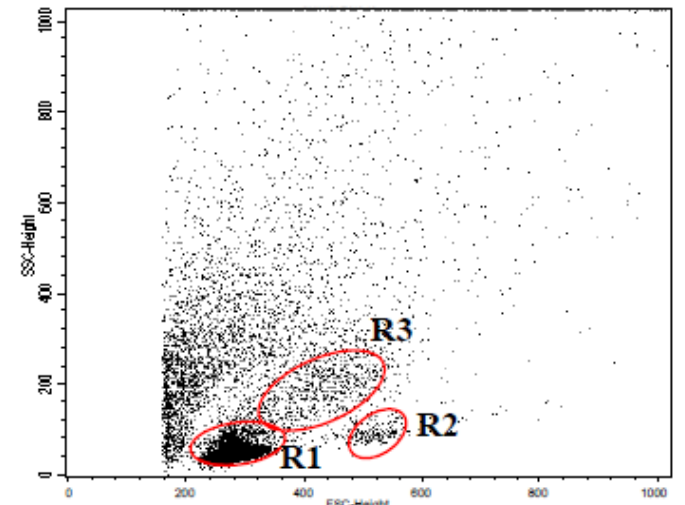

(A)

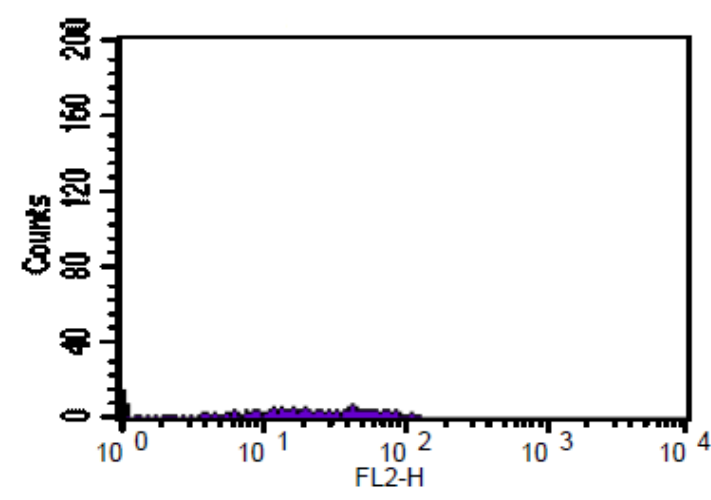

(B)

Fonte: (ALVES, G. J., 2006)

Legenda: (A) e Histograma (B) dos neutrófilos incubados com o S.aureusrealizando fagocitose. R1=linfócitos; $\mathrm{R} 2=$ =monócitos; R3=neutrófilos

Figura 25- Citogramas de leucócitos circulantes de camundongos incubados com PBS

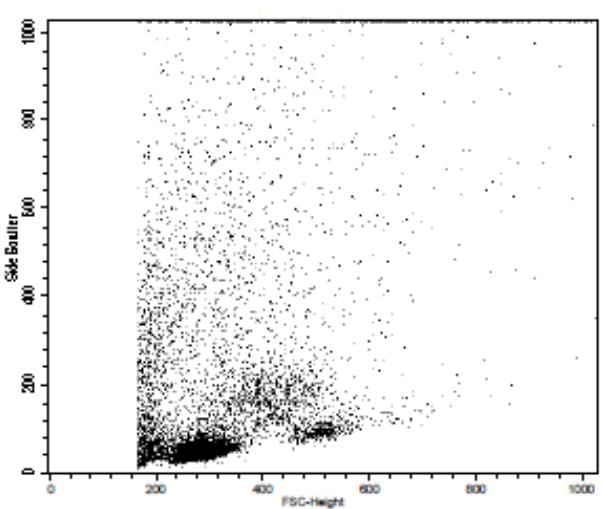

Citograma do tubo A

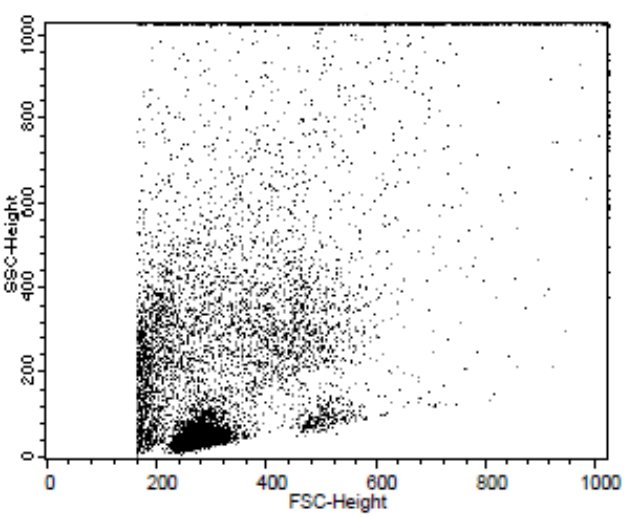

Citograma do tubo $\mathrm{C}$

Fonte: (ALVES, G. J., 2006)

Legenda: (TUBO A) e citograma de leucócitos circulantes de camundongos incubados com S.aureus realizando fagocitose (TUBO C) em animais do grupo controle 
Figura 26- Histograma de neutrófilos de animais do grupo controle incubado com S. aureus realizando fagocitose

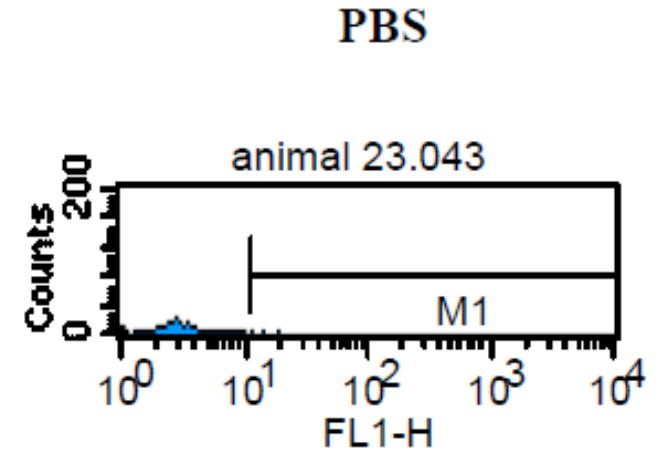

(1)

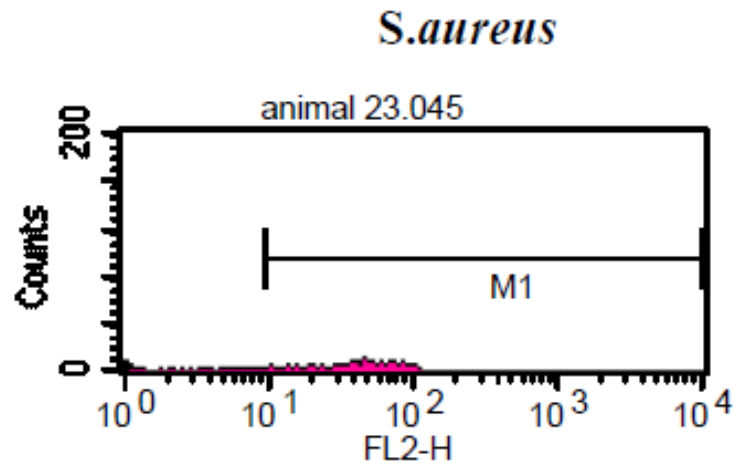

(2)

Fonte: (ALVES, G. J., 2006)

Legenda: (1) Histograma de células controle isto é,incubadas apenas com PBS.(2) Histograma da porcentagem de neutrófilos incubados com S.aureus realizando fagocitose

A tabela 2 mostra os resultados do presente experimento referente aos efeitos da convivência com o animal doente por 11 dias sobre o burst oxidativo espontâneo e sobre aqueles induzidos por PMA e Staphylococcus aureus, bem como outros relativos à fagocitose desta bactéria realizada por neutrófilos. Foram observadas diferenças significantes entre CAS e CAD.

A figura 27 ilustra a intensidade de fluorescência decorrente do burst oxidativo basal de neutrófilos (apenas com DCFH) após os 11 dias de convivência com o animal com tumor e avaliados por citometria de fluxo; não foram verificadas diferenças significantes entre os grupos ( $\mathrm{p}>0,05)$. O busrt oxidativo dos neutrófilos dos animais do grupo experimental (CAD) foi reduzido significantemente em relação ao medido nos animais CAS quando induzido pelo PMA $(\mathrm{p} \leq 0,05)$ como ilustra a figura 28. De igual forma, observa-se redução do burst oxidativo dos neutrófilos dos animais do grupo experimental (CAD) após indução por $S$. aureus $(\mathrm{p} \leq 0,05)$ como ilustra a figura 29. As figuras 30 e 31 ilustram estes dois últimos dados em porcentagem respectivamente $(\mathrm{p} \leq 0,05)$. 
Tabela 2- Efeitos da convivência por 11 dias com portadores de um tumor de Ehrlich, sobre o burstoxidativo e sobre a fagocitose de neutrófilos medidos por Citometria de Fluxo

Condição CAS CAD

\begin{tabular}{lcc} 
DCFH & $82,38 \pm 39,42$ & $77,07 \pm 32,56$ \\
PMA & $334,8 \pm 83,34$ & $220,1 \pm 69,71^{*}$ \\
Burst induzido pela S. aureus & $378,6 \pm 142,3$ & $184,3 \pm 78,63^{*}$ \\
\% de fagocitose & $80,94 \pm 5,400$ & $79,47 \pm 10,66$ \\
Intensidade de fagocitose & $58,77 \pm 10,57$ & $56,97 \pm 11,18$ \\
\hline
\end{tabular}

Notas:Os dados representam a intensidade média de fluorescência (média \pm desvio padrão), correspondente ao gate da população de neutrófilos circulantes.

*Estatisticamentesignificante, diferente do controle (CAS), $p \leq 0,05$, teste " $t$ " de Student.

$\mathrm{CAS}=$ companheiros dos animais injetados com PBS; CAD= companheiros dos animais inoculados com o tumor ascítico de Ehrlich.

Figura 27- Efeitos da convivência com portadores de um tumor ascítico de Ehrlich, por 11 dias sobre o burst oxidativo basal de neutrófilos

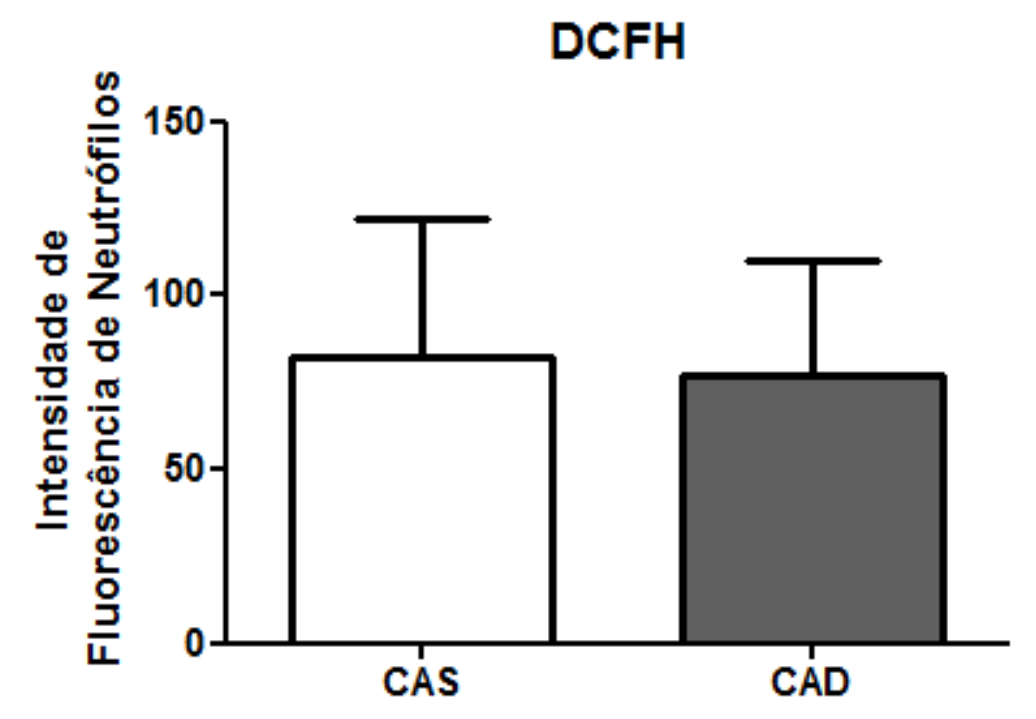

Legenda: $\mathrm{CAS}=$ companheiros dos animais injetados com PBS; CAD $=$ companheiros dos animais inoculados com o tumor ascítico de Ehrlich. Os dados representam a média \pm o desvio padrão de 7 animais por grupo, $\mathrm{p}>0,05$ (teste " $\mathrm{t}$ " de Student) 
Figura 28- Efeitos da convivência com portadores de um tumor ascítico de Ehrlich, por 11 dias sobre o burstoxidativo de neutrófilos induzido por PMA

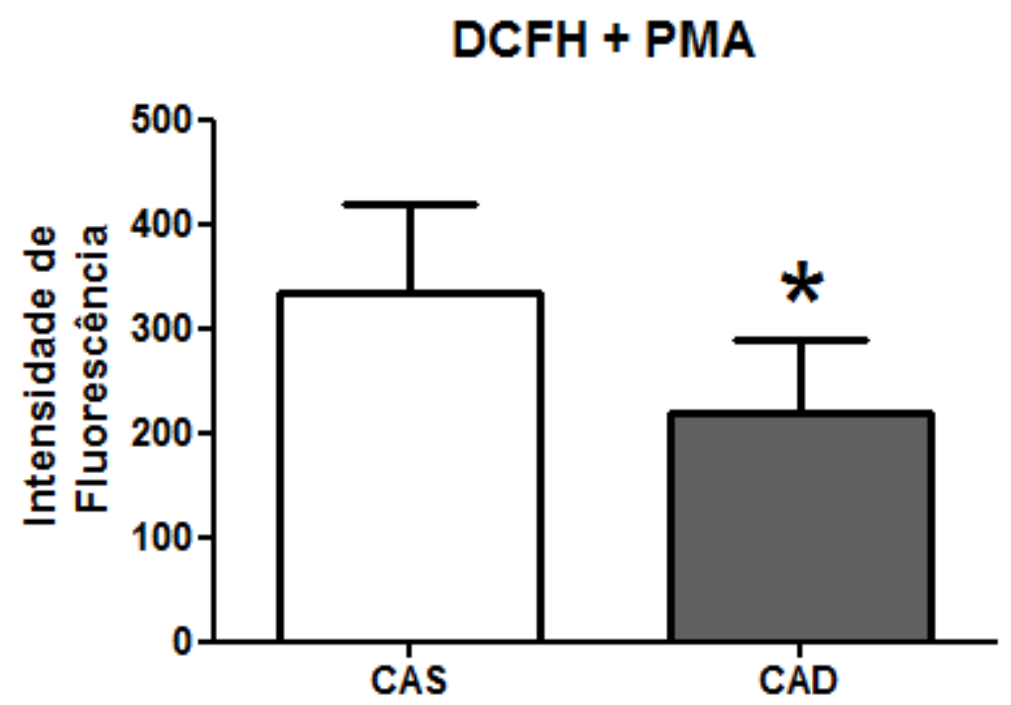

Legenda: $\mathrm{CAS}=$ companheiros dos animais injetados com PBS; CAD= companheiros dos animais inoculados com o tumor ascítico de Ehrlich. Os dados representam a média \pm o desvio padrão de 7 animais por grupo, $\mathrm{p} \leq 0,05$ (teste " $\mathrm{t}$ " de Student)

Figura 29- Efeitos da convivência com portadores de um tumor ascítico de Ehrlich, por 11 dias sobre o burstoxidativo de neutrófilos induzido por S. aureus

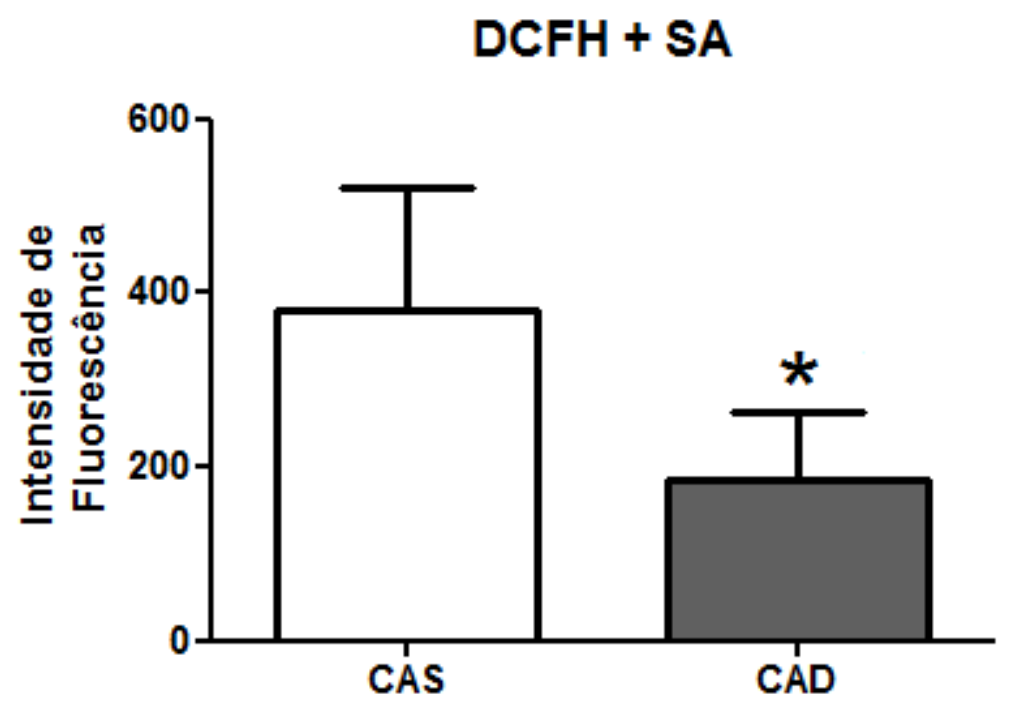

Legenda: $\mathrm{CAS}=$ companheiros dos animais injetados com PBS; CAD= companheiros dos animais inoculados com o tumor ascítico de Ehrlich. Os dados representam a média \pm o desvio padrão de 7 animais por grupo, $\mathrm{p} \leq 0,05$ (teste " $\mathrm{t}$ " de Student) 
Figura 30- Efeitos da convivência com portadores de um tumor ascítico de Ehrlich, por 11 dias sobre o burstoxidativo de neutrófilos induzido por PMA expresso em porcentagem

\section{DCFH+PMA em \%}

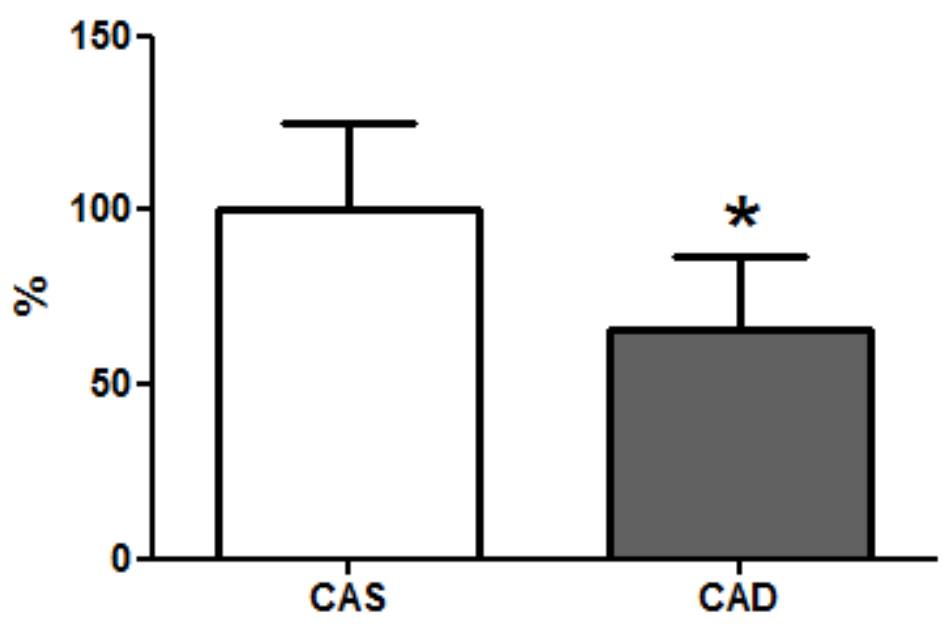

Legenda: $\mathrm{CAS}=$ companheiros dos animais injetados com PBS; CAD = companheiros dos animais inoculados com o tumor ascítico de Ehrlich. Os dados representam a média \pm o desvio padrão de 7 animais por grupo, $\mathrm{p} \leq 0,05$ (teste " $\mathrm{t}$ " de Student).

Figura 31- Efeitos da convivência com portadores de um tumor ascítico de Ehrlich, por 11 dias sobre o burst oxidativo de neutrófilos induzido por $S$. aureus expresso em porcentagem

\section{DCFH+SA em \%}

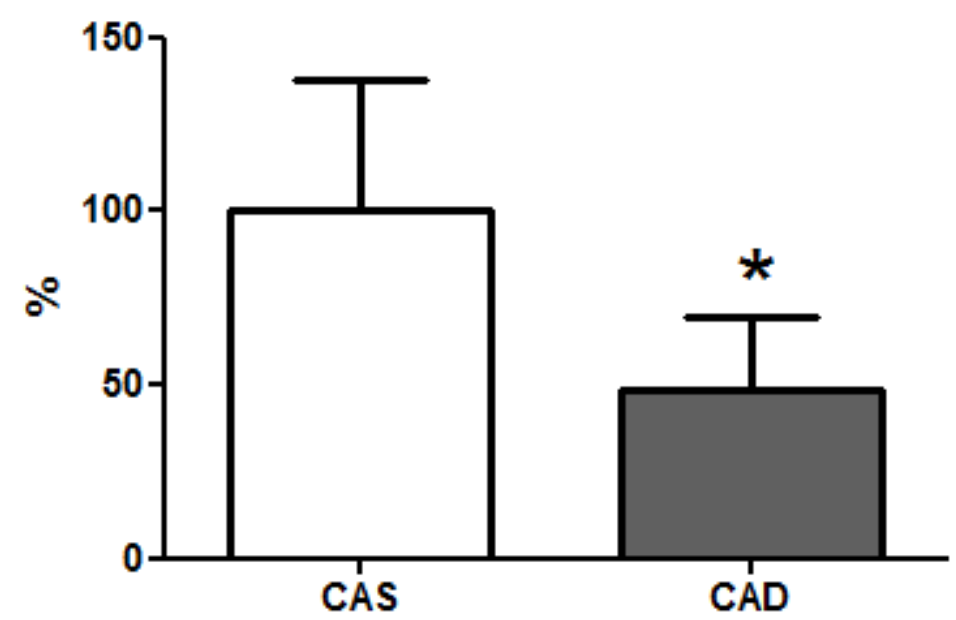

Legenda: $\mathrm{CAS}=$ companheiros dos animais injetados com PBS; CAD= companheiros dos animais inoculados com o tumor ascítico de Ehrlich. Os dados representam a média \pm o desvio padrão de 7 animais por grupo, $\mathrm{p} \leq 0,05$ (teste " $\mathrm{t}$ ” de Student) 
Observou-se que a convivência com o animal inoculado com células do tumor ascítico de Ehrlich não houve diferenças significantes entre CAS e CAD em relação à intensidade e porcentagem de fagocitose como ilustram as figuras 32 e 33 respectivamente.

Figura 32- Efeitos da convivência com portadores de um tumor ascítico de Ehrlich, por 11 dias sobre a intensidade de fagocitose de neutrófilos

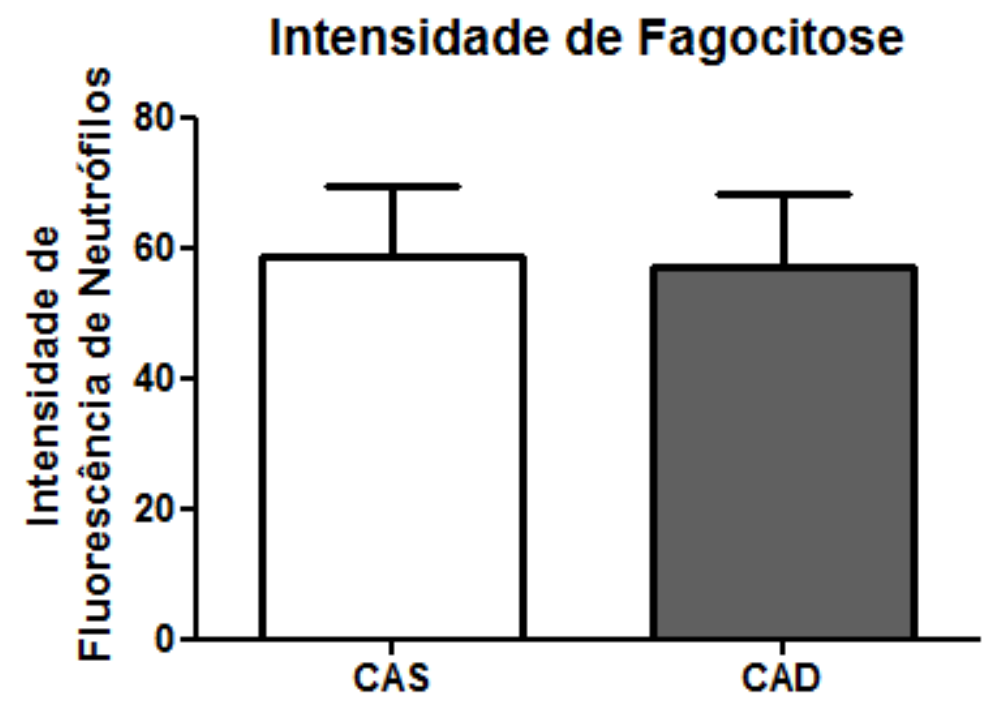

Legenda: CAS = companheiros dos animais injetados com PBS; CAD= companheiros dos animais inoculados com o tumor ascítico de Ehrlich. Os dados representam a média \pm o desvio padrão de 7 animais por grupo, $\mathrm{p}>0,05$ (teste " $\mathrm{t}$ " de Student)

Figura 33- Efeitos da convivência com portadores de um tumor ascítico de Ehrlich, por 11 dias sobre a porcentagem de fagocitose de neutrófilos

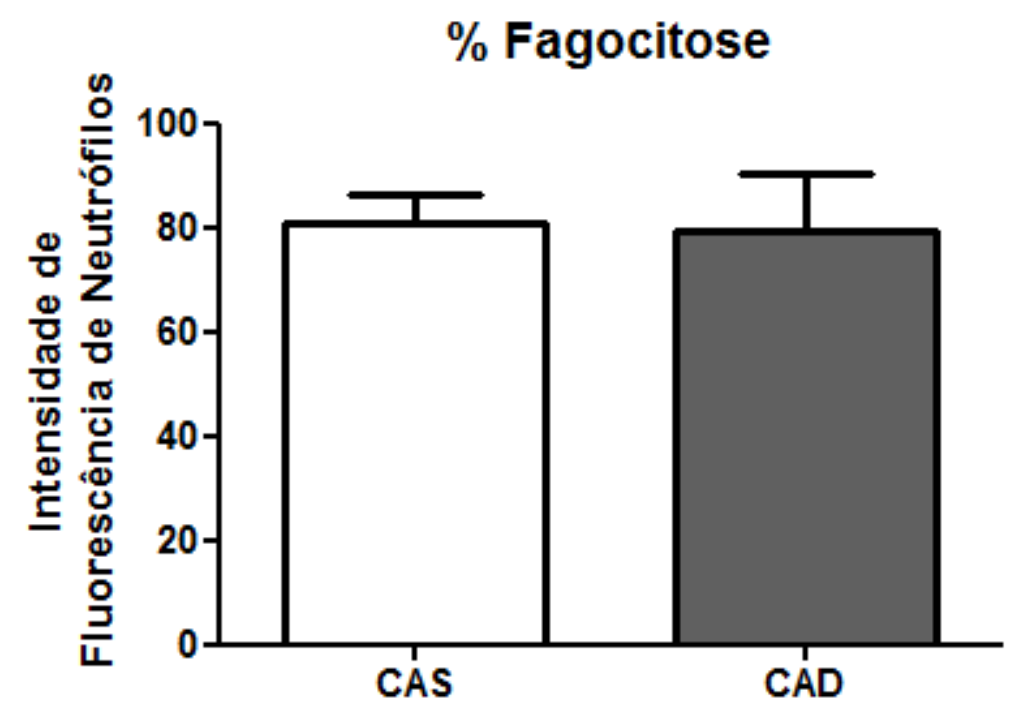

Legenda: $\mathrm{CAS}=$ companheiros dos animais injetados com PBS; CAD= companheiros dos animais inoculados com o tumor ascítico de Ehrlich. Os dados representam a média \pm o desvio padrão de 7 animais por grupo, $\mathrm{p}>0,05$ (teste “t” de Student) 


\subsection{EXPERIMENTO 5- AVALIAÇÃO DO CRESCIMENTO DE UM TUMOR ASCÍTICO DE EHRLICH NO $11^{\circ}$ DIA DE CONVIVÊNCIA COM O DOENTE}

Conforme descrito no item 4.2., foram utilizados 66 camundongos os quais foram separados em pares, de acordo com o peso corporal em dois grupos: um grupo controle e um grupo experimental. No dia (0) do experimento um camundongo de cada par controle foi inoculado com PBS i.p. e um camundongo de cada par experimental foi inoculado com

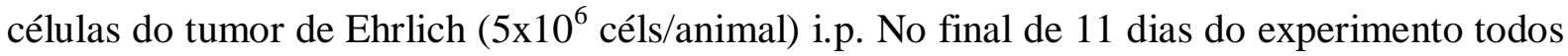
os animais companheiros (CAS e CAD) foram inoculados intraperitoneal com o Tumor ascítico de Ehrlich em uma concentração de 5 x $10^{6}$ células tumorais/animal sendo os de cada grupo alojados em um número máximo de 6 em gaiolas de propileno (medindo 41x34x16 cm). Após 11 dias procedeu-se a verificação do crescimento tumoral nos camundongos dos grupos CAS e CAD como descrito no item 4.8. A figura 7 mostra este delineamento.

\section{Resultados}

A tabela 3 mostra e as figuras 34, 35, e 36 ilustram os efeitos da convivência por 11 dias com animais portadores do tumor de Ehrlich sobre o crescimento do mesmo tumor ascítico.

A análise estatística mostrou a existência de diferenças significantes $(p \leq 0,05)$ entre os dados obtidos após a convivência com o animal doente durante 11 dias no relativo ao crescimento tumoral avaliado por meio dos seguintes parâmetros: concentração de células tumorais $(\mathrm{p} \leq 0,05)$ e número de células tumorais totais $(\mathrm{p} \leq 0,05)$; no entanto, não foram encontradas diferenças no volume de líquido ascítico ( $p>0,05)$. Especificamente, observou-se que a convivência por 11 dias com portadores do tumor de Ehrlich aumentou a concentração e o número de células do tumor ascítico de Ehrlich, isto é, a convivência com o animal doente diminuiu a resistência orgânica doa animais ao crescimento tumoral. 
Tabela 3- Efeitos da convivência por 11 dias com portadores de um tumor ascítico de Ehrlich sobre o volume $(\mathrm{ml})$, concentração e número total de células após inoculação do tumor ascítico de Ehrlich ( $5 \times 10^{6}$ células tumorais/animal)

\begin{tabular}{cccc} 
Grupos & Volume $(\mathrm{ml})$ & $\begin{array}{c}\text { Concentração } \\
\left(\mathbf{n}^{\circ} \text { de células } / \mathbf{m l} \mathbf{1 \times 1 0 ^ { 7 } )}\right.\end{array}$ & $\begin{array}{c}\text { Células Totais } \\
\left(\mathbf{n}^{\circ} \text { de células/animal }\right. \\
\mathbf{1 \times 1 0 ^ { 7 } )}\end{array}$ \\
\hline CAS & $14,13 \pm 2,735$ & $15,79 \pm 3,708$ & $212,7 \pm 62,72$ \\
CAD & $12,86 \pm 3,859$ & $23,41 \pm 6,314^{*}$ & $326,4 \pm 105,0^{*}$ \\
\hline
\end{tabular}

Notas: Os dados apresentam a média \pm desvio padrão

*Estatisticamentesignificante, diferente do controle (CAS), $\mathrm{p} \leq 0,05$, teste " $\mathrm{t}$ " de Student

$\mathrm{CAS}=$ companheiros dos animais injetados com PBS; $\mathrm{CAD}=$ companheiros dos animais inoculados com o tumor ascítico de Ehrlich.

Figura 34- Efeitos da convivência por 11 dias com portadores do tumor ascítico de Ehrlich sobre aconcentração de células tumorais/ml (x107) de camundongos inoculados com o mesmo tumor (5 x 106células)

\section{Concentração de Células Tumorais}

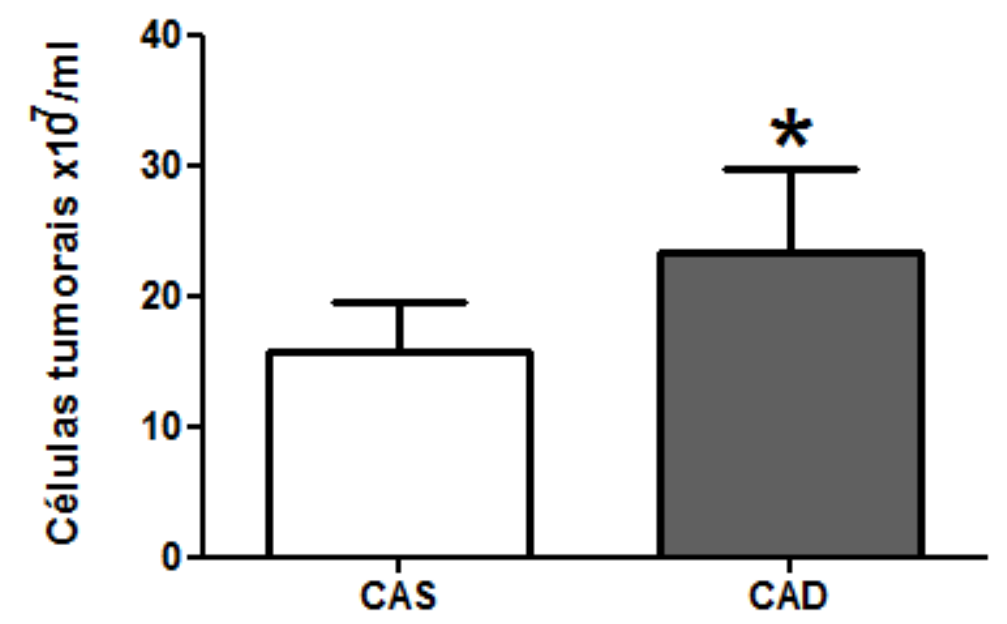

Legenda: $\mathrm{CAS}=$ companheiros dos animais injetados com PBS; CAD $=$ companheiros dos animais inoculados com o tumor ascítico de Ehrlich. Os dados representam a média \pm o desvio padrão de 8 animais por grupo, $\mathrm{p} \leq 0,05$ (teste " $\mathrm{t}$ " de Student). 
Figura 35- Efeitos da convivência por 11 dias com portadores do tumor ascítico de Ehrlich sobre o número de células tumorais totais (x107) de camundongos inoculados com o mesmo tumor (5 x 106células)

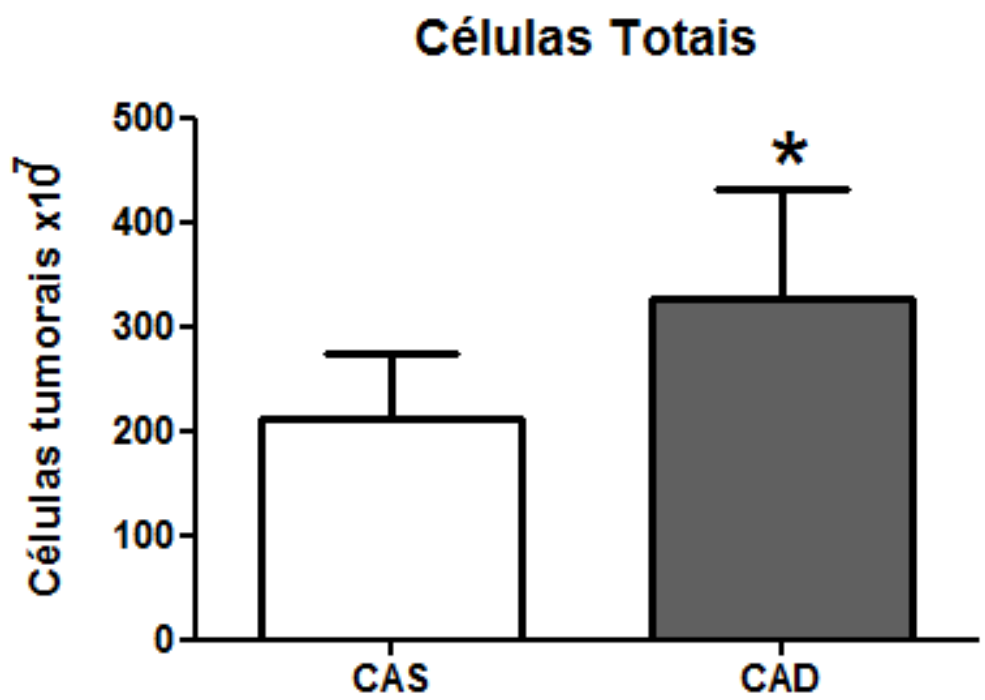

Legenda: $\mathrm{CAS}=$ companheiros dos animais injetados com PBS; CAD $=$ companheiros dos animais inoculados com o tumor ascítico de Ehrlich. Os dados representam a média \pm o desvio padrão de 8 animais por grupo, $\mathrm{p} \leq 0,05$ (teste " $\mathrm{t}$ " de Student)

Figura 36- Efeitos da convivência por 11 dias com portadores do tumor ascítico de Ehrlich sobre o volume de líquido ascítico em $\mathrm{ml}$ de camundongos inoculados com o mesmo tumor (5 x $10^{6}$ células)

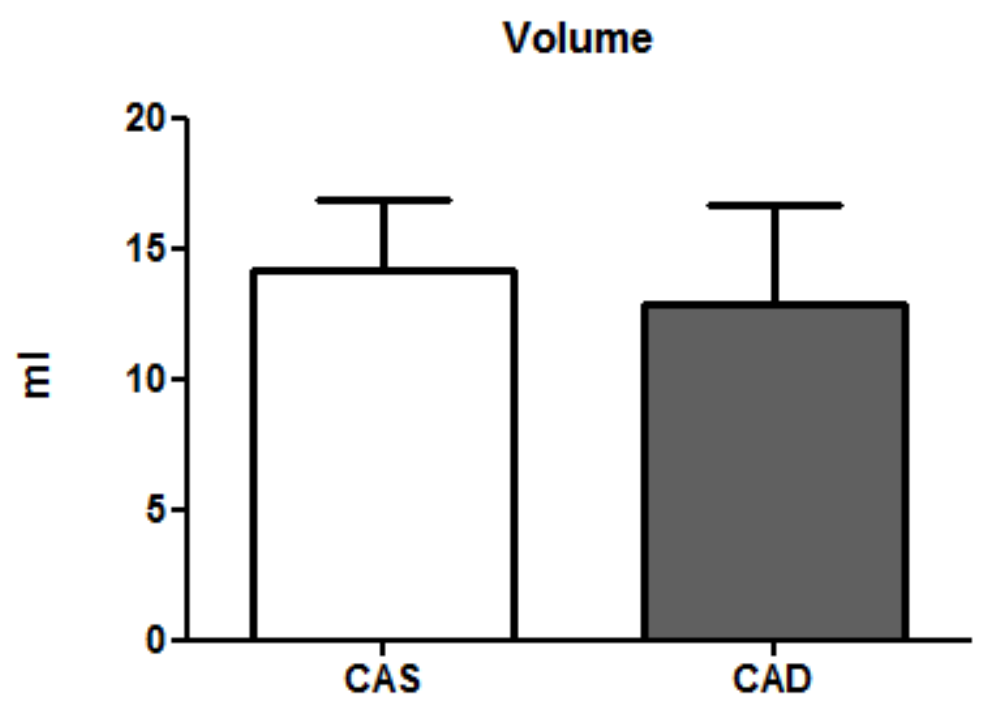

Legenda: CAS = companheiros dos animais injetados com PBS; CAD = companheiros dos animais inoculados com o tumor ascítico de Ehrlich. Os dados representam a média \pm o desvio padrão de 8 animais por grupo, $p>0,05$ (teste " $t$ " de Student) 


\subsection{EXPERIMENTO 6- MEDIDA DE ATIVIDADE GERAL DOS ANIMAIS NO $11^{\circ}$ DIA DE CONVIVÊNCIA COM O DOENTE NO CAMPO ABERTO}

Conforme descrito no item 4.2., foram utilizados 50 camundongos os quais foram separados em pares, de acordo com o peso corporal em dois grupos: um grupo controle e um grupo experimental. No dia (0) do experimento um camundongo de cada par controle foi inoculado com PBS i.p. e um camundongo de cada par experimental foi inoculado com células do tumor de Ehrlich $\left(5 \times 10^{6}\right.$ céls/animal) i.p. No $11^{\circ}$ dia de convivência os animais companheiros dos inoculados com PBS (CAS) ou tumor de Ehrlich (CAD) foram colocados individualmente no centro da arena do campo aberto que registra a atividade geral como descrito no item 4.9.

\section{Resultados}

Foi avaliada a locomoção dos camundongos em diferentes zonas no campo aberto; central e periférica (zona tigmotáxica). Não foram observadas diferenças estatísticas significantes quanto aos parâmetros analisados como ilustram as figuras de 37 a 45 (p>0,05).

Figura 37- Efeitos da convivência por 11 dias com portadores do tumor ascítico de Ehrlich sobre a distância total em centímetros percorrida no campo aberto

\section{Distância total percorrida}

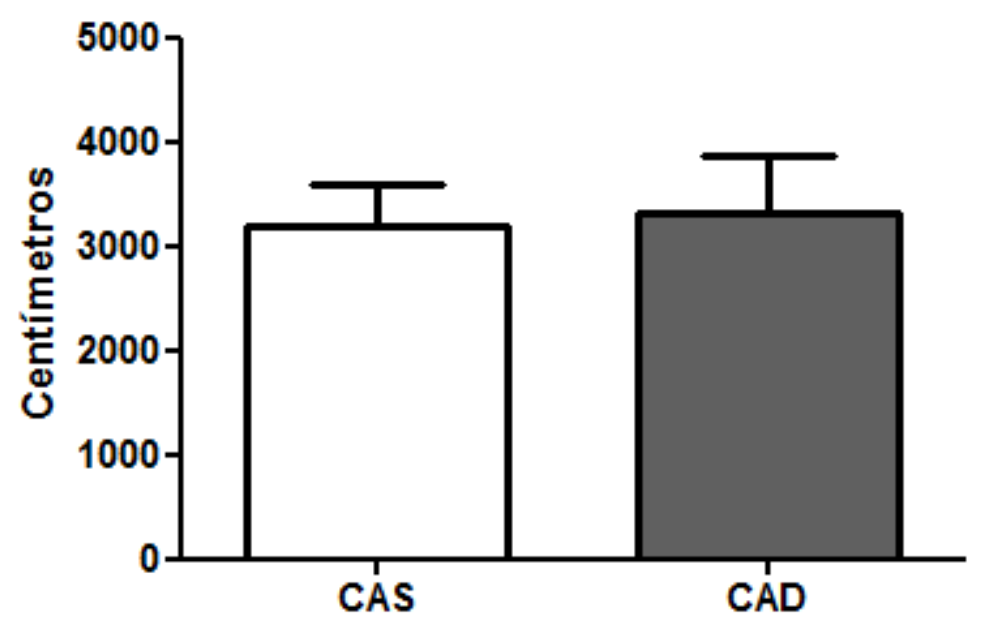

Legenda: CAS = companheiros dos animais injetados com PBS; CAD= companheiros dos animais inoculados com o tumor ascítico de Ehrlich. Os dados representam a média \pm o desvio padrão de 8 animais por grupo, $\mathrm{p}>0,05$ (teste " $\mathrm{t}$ " de Student) 
Figura 38- Efeitos da convivência por 11 dias com portadores do tumor ascítico de Ehrlich sobre o tempo em segundos de permanência na zona periférica do campo aberto

\section{Segundos na zona periférica}

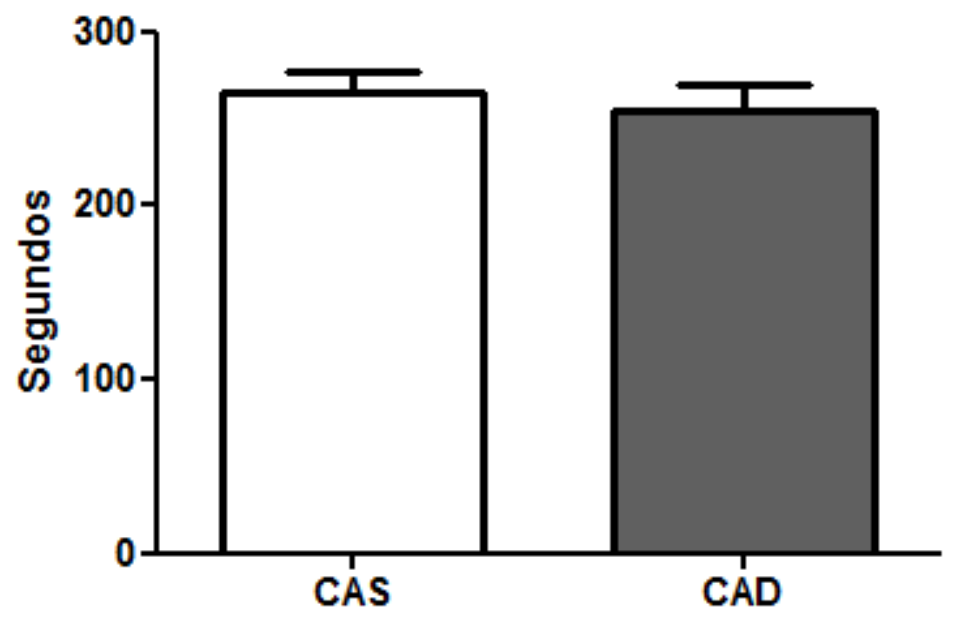

Legenda: $\mathrm{CAS}=$ companheiros dos animais injetados com PBS; CAD $=$ companheiros dos animais inoculados com o tumor ascítico de Ehrlich. Os dados representam a média \pm o desvio padrão de 8 animais por grupo, $\mathrm{p}>0,05$ (teste " $\mathrm{t}$ " de Student)

Figura 39- Efeitos da convivência por 11 dias com portadores do tumor ascítico de Ehrlich sobre o número de entradas na zona periférica do campo aberto

\section{Frequencia na zona periférica}

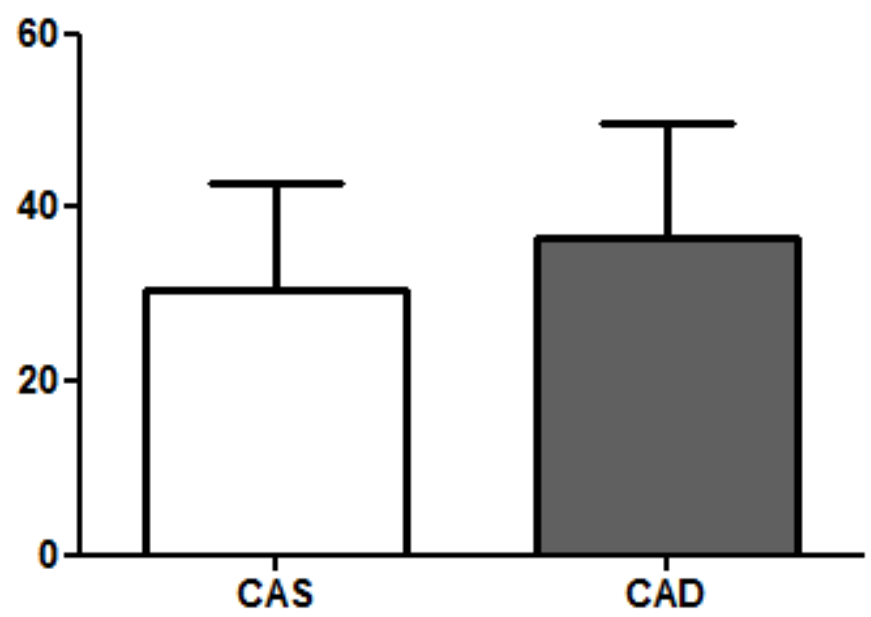

Legenda: $\mathrm{CAS}=$ companheiros dos animais injetados com PBS; $\mathrm{CAD}=$ companheiros dos animais inoculados com o tumor ascítico de Ehrlich. Os dados representam a média \pm o desvio padrão de 8 animais por grupo, $\mathrm{p}>0,05$ (teste " $\mathrm{t}$ " de Student) 
Figura 40- Efeitos da convivência por 11 dias com portadores do tumor ascítico de Ehrlich sobre o tempo em segundos de permanência na zona central do campo aberto

\section{Segundos na zona central}

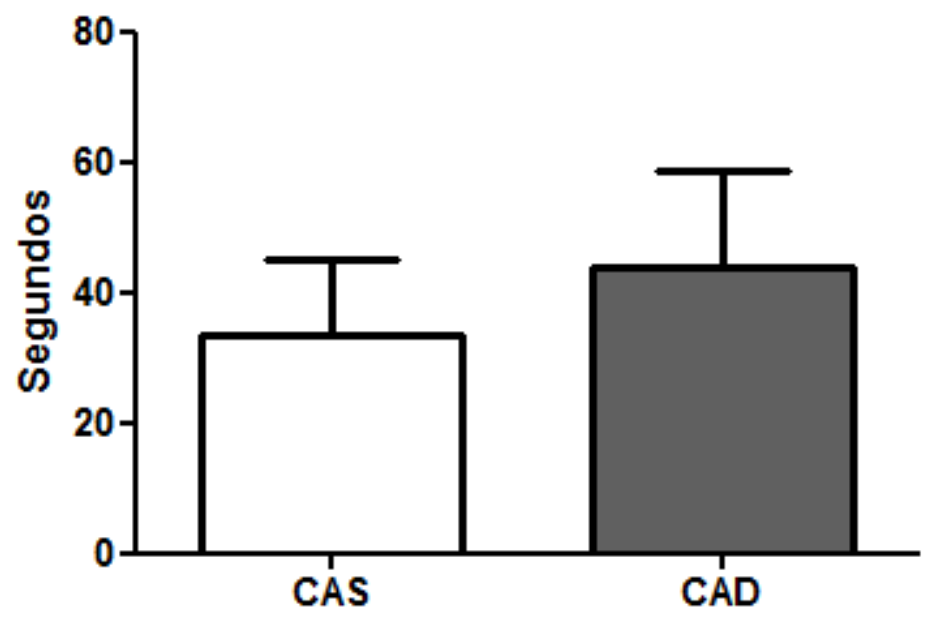

Legenda: $\mathrm{CAS}=$ companheiros dos animais injetados com PBS; $\mathrm{CAD}=$ companheiros dos animais inoculados com o tumor ascítico de Ehrlich. Os dados representam a média \pm o desvio padrão de 8 animais por grupo, $p>0,05$ (teste " $t$ " de Student)

Figura 41- Efeitos da convivência por 11 dias com portadores do tumor ascítico de Ehrlich sobreo número de entradas na zona central do campo aberto

\section{Frequencia na zona central}

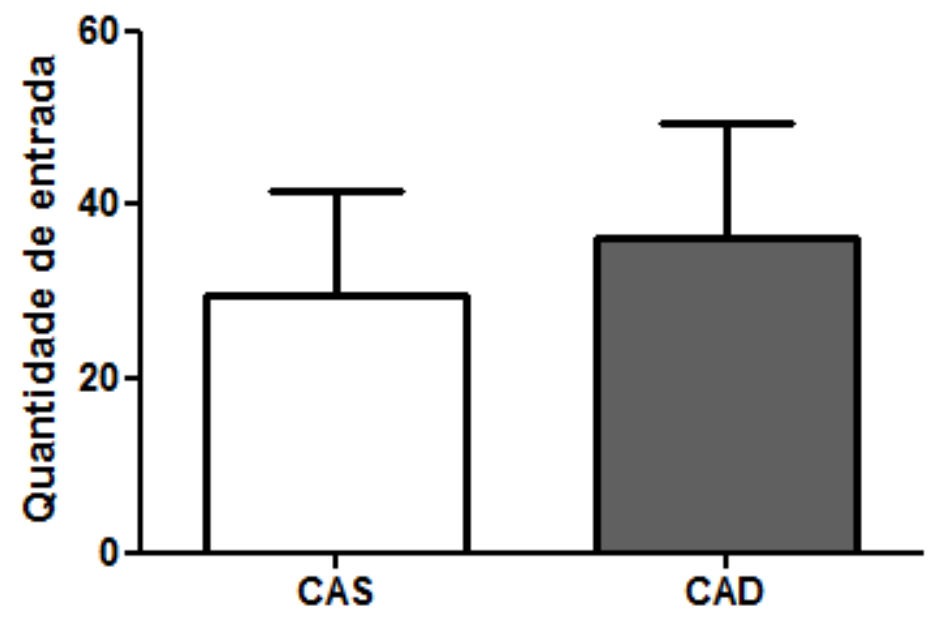

Legenda: $\mathrm{CAS}=$ companheiros dos animais injetados com PBS; $\mathrm{CAD}=$ companheiros dos animais inoculados com o tumor ascítico de Ehrlich. Os dados representam a média \pm o desvio padrão de 8 animais por, $\mathrm{p}>0,05$ (teste " $\mathrm{t}$ " de Student) 
Figura 42- Efeitos da convivência por 11 dias com portadores do tumor ascítico de Ehrlich sobre o tempo em segundos de imobilidade no campo aberto

\section{Duração de imobilidade}

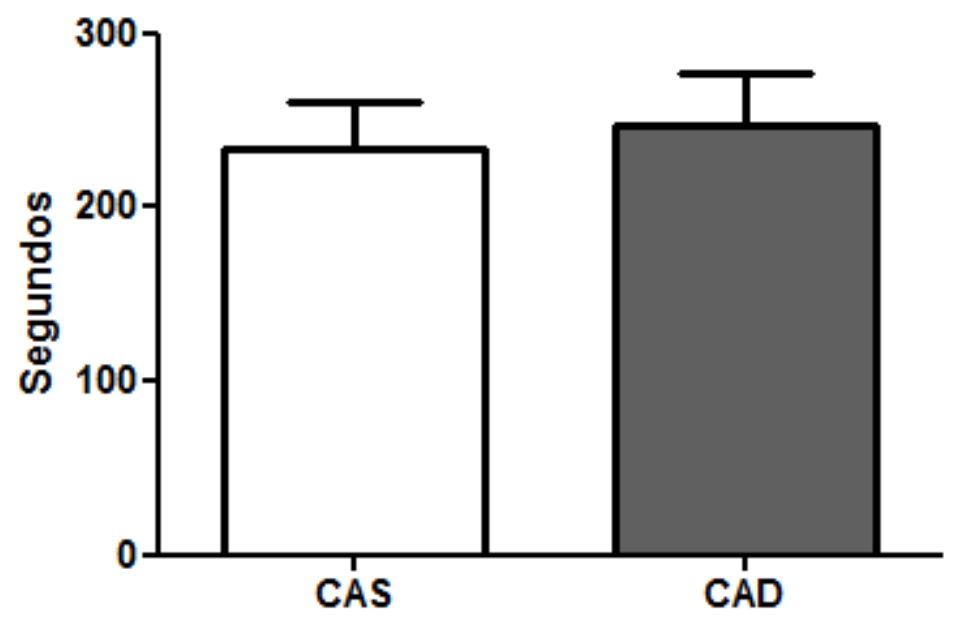

Legenda: $\mathrm{CAS}=$ companheiros dos animais injetados com PBS; $\mathrm{CAD}=$ companheiros dos animais inoculados com o tumor ascítico de Ehrlich. Os dados representam a média \pm o desvio padrão de 8 animais por grupo, $\mathrm{p}>0,05$ (teste " $\mathrm{t}$ " de Student)

Figura 43- Efeitos da convivência por 11 dias com portadores do tumor ascítico de Ehrlich sobre o número de início de movimentos no campo aberto

\section{Frequencia de mobilidade}

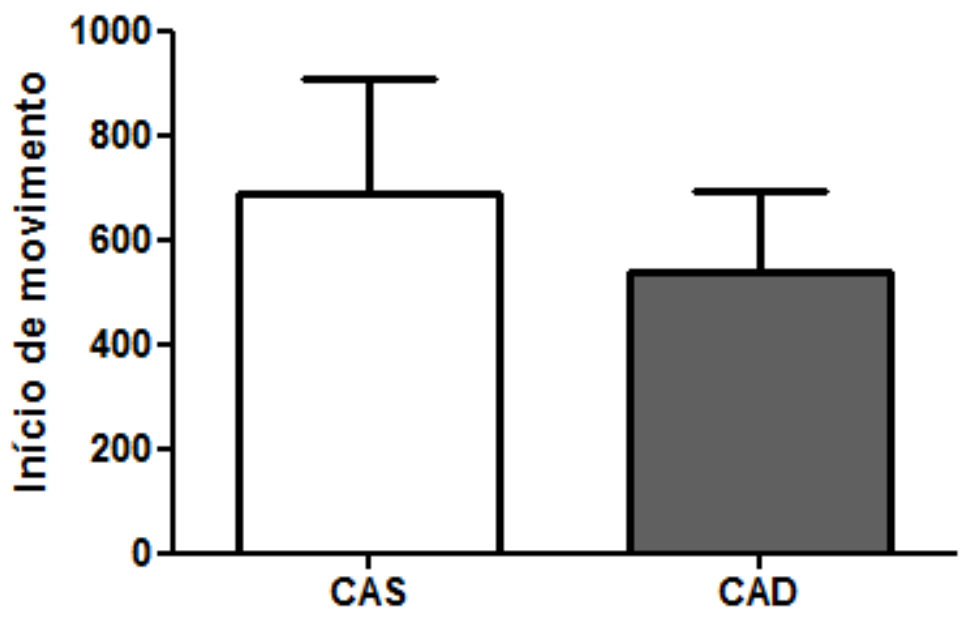

Legenda: $\mathrm{CAS}=$ companheiros dos animais injetados com PBS; CAD $=$ companheiros dos animais inoculados com o tumor ascítico de Ehrlich. Os dados representam a média \pm o desvio padrão de 8 animais por grupo, $p>0,05$ (teste " $t$ " de Student) 
Figura 44- Efeitos da convivência por 11 dias com portadores do tumor ascítico de Ehrlich sobre o tempo em segundos de movimento no campo aberto

\section{Duração de mobilidade}

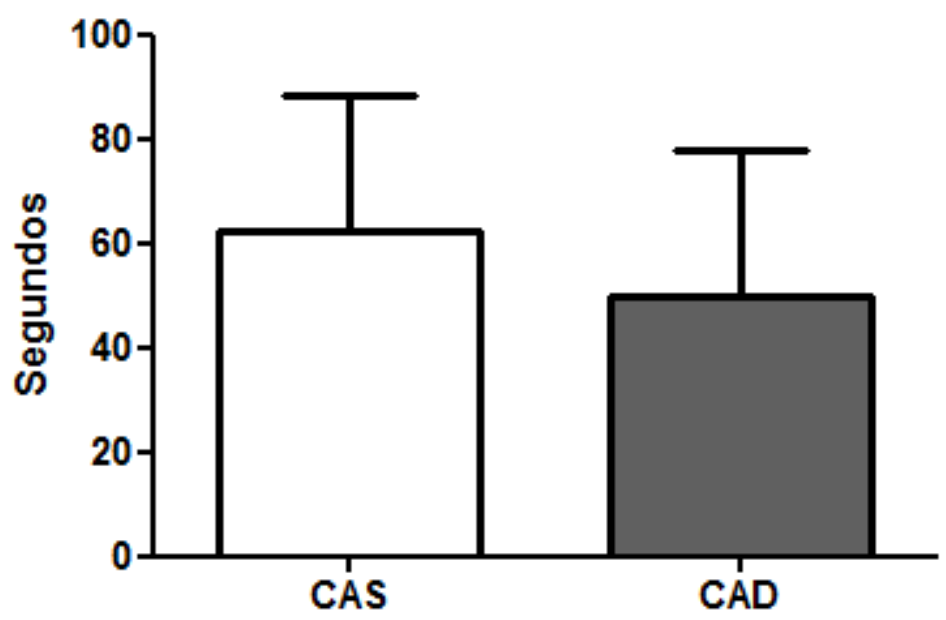

Legenda: $\mathrm{CAS}=$ companheiros dos animais injetados com PBS; CAD= companheiros dos animais inoculados com o tumor ascítico de Ehrlich. Os dados representam a média \pm o desvio padrão de 8 animais por grupo, $\mathrm{p}>0,05$ (teste “t” de Student)

Figura 45- Efeitos da convivência por 11 dias com portadores do tumor ascítico de Ehrlich sobre a velocidade média em $\mathrm{cm} / \mathrm{sg}$ percorrida no campo aberto

\section{Velocidade média}

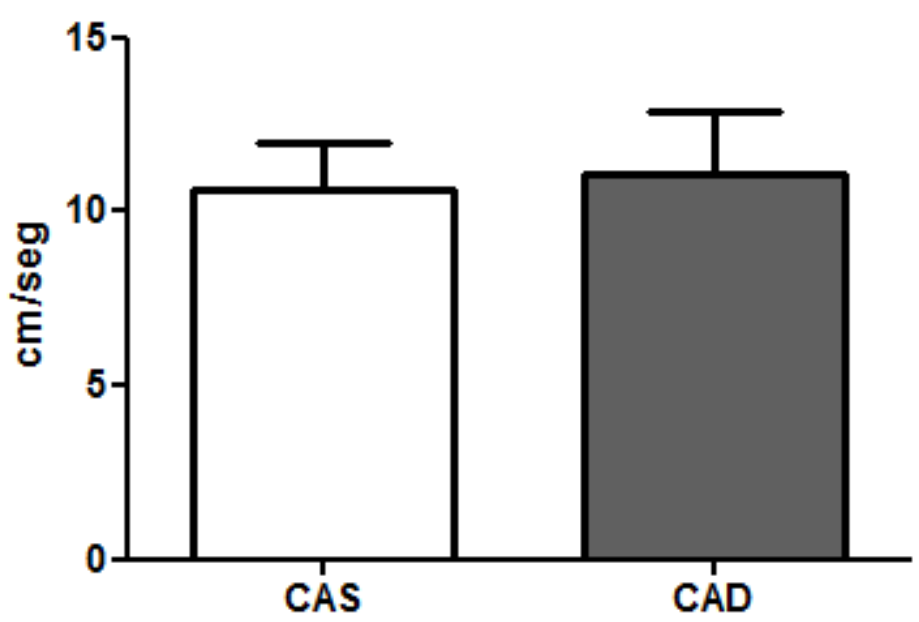

Legenda: $\mathrm{CAS}=$ companheiros dos animais injetados com PBS; CAD= companheiros dos animais inoculados com o tumor ascítico de Ehrlich. Os dados representam a média \pm o desvio padrão de 8 animais por grupo, $\mathrm{p}>0,05$ (teste “t” de Student) 


\subsection{EXPERIMENTO 7- DOSAGEM DE MONOAMINAS E DE SEUS METABÓLITOS NO HIPOTÁlAMO, BULBO E CÓRTEX FRONTAL NO $11^{\circ}$ DIA DE CONVIVÊNCIA COM O DOENTE}

Conforme descrito no item 4.2., foram utilizados 48 camundongos os quais foram separados em pares, de acordo com o peso corporal em dois grupos: um grupo controle e um grupo experimental. No dia (0) do experimento um camundongo de cada par controle foi inoculado com PBS i.p. e um camundongo de cada par experimental foi inoculado com células do tumor de Ehrlich $\left(5 \times 10^{6}\right.$ céls/animal) i.p. No $11^{\circ}$ dia de convivência os animais companheiros dos inoculados com PBS (CAS) ou tumor de Ehrlich (CAD) foram submetidos à eutanásia por decaptação e as estruturas do Sistema Nervoso Central foram coletadas como descrito no item 4.10. Foram dosados os seguintes neurotransmissores noradrenalina (NOR), dopamina (DA) e serotonina (5HT), bem como seus metabólitos ácido vanilmandélico (VMA); ácido 3,4 diidroxifenilacético (DOPAC), ácido 4 hidroxi 3-metil homovanílico (HVA) e ácido 5 hidroxi 3-indolacético (5HIAA). Desta forma, foi possível inferir nos dados de turnover destes neurotransmissores nestes animais conforme especificado em 4.10.

\section{Resultados}

A tabela 4 mostra e as figuras de 46 a 63 ilustram os efeitos da convivência com camundongos portadores do tumor ascítico de Ehrlich durante 11 dias sobre os níveis e turnover de neurotransmissores medidos no hipotálamo, córtex frontal e bulbo cerebral.

Como pode ser observada, a convivência com o animal portador do tumor diminuiu os níveis de noradrenalina e HVA no bulbo; aumentou os níveis de serotonina, 5-HIAA, VMA e o turnover VMA/NOR no córtex frontal e diminuiu os níveis de HVA no hipotálamo em relação ao grupo controle $(\mathrm{p} \leq 0,05)$. Não se observaram diferenças estatísticas para os outros parâmetros analisados. Os valores VMA no hipotálamo estavam abaixo do nível de detecção da metodologia, não sendo possível a leitura pelo aparelho de HPLC. 
Tabela 4- Efeitos da convivência por 11 dias com portadores de um tumor ascético de Ehrlich, sobre os níveis e "turnover" hipotalâmicos, corticais e bulbar de noradrenalina, dopamina, serotonina e seus metabólitos

\begin{tabular}{|c|c|c|c|c|c|c|}
\hline \multirow[b]{2}{*}{ PARÂMETROS } & \multicolumn{2}{|c|}{ HIPOTÁLAMO } & \multicolumn{2}{|c|}{ CÓRTEX FRONTAL } & \multicolumn{2}{|c|}{ BULBO } \\
\hline & CAS & CAD & CAS & CAD & CAS & CAD \\
\hline NOR & $2466 \pm 821,4$ & $2392 \pm 603,8$ & $479,9 \pm 123,9$ & $544,9 \pm 178,9$ & $455,7 \pm 75,91$ & $393,2 \pm 393,2^{*}$ \\
\hline MHPG & - & - & - & - & - & - \\
\hline VMA & - & - & $174,6 \pm 36,16$ & $263,1 \pm 84,92^{*}$ & $185,3 \pm 6,377$ & $171,7 \pm 16,58$ \\
\hline VMA/NOR & - & - & $0,3373 \pm 0,06897$ & $0,5128 \pm 0,2291^{*}$ & $0,4354 \pm 0,1128$ & $0,4018 \pm 0,1326$ \\
\hline DA & $469,6 \pm 109,6$ & $372,7 \pm 140,7$ & $256 \pm 276,0$ & $124,6 \pm 209,2$ & $187,3 \pm 53,24$ & $169,1 \pm 38,84$ \\
\hline HVA & $198,1 \pm 15,35$ & $138,9 \pm 47,86^{*}$ & $95,1 \pm 87,90$ & $86,73 \pm 55,15$ & $160,2 \pm 16,59$ & $119,6 \pm 36,46^{*}$ \\
\hline DOPAC & $142,9 \pm 16,94$ & $145,9 \pm 21,59$ & $77,56 \pm 56,20$ & $100,9 \pm 76,29$ & $80,74 \pm 25,42$ & $76,95 \pm 23,55$ \\
\hline HVA/DA & $0,4188 \pm 0,1011$ & $0,343 \pm 0,2098$ & $0,7068 \pm 1,109$ & $0,7774 \pm 0,9285$ & $0,8119 \pm 0,2245$ & $0,7561 \pm 0,3420$ \\
\hline DOPAC/DA & $0,303 \pm 0,1194$ & $0,3975 \pm 0,2385$ & $1,208 \pm 1,789$ & $1,391 \pm 1,717$ & $0,4986 \pm 0,1799$ & $0,5341 \pm 0,1399$ \\
\hline HVA+DOPAC/DA & $0,6846 \pm 0,2563$ & $0,589 \pm 0,1793$ & $3,803 \pm 5,348$ & $5,885 \pm 9,053$ & $1,258 \pm 0,2561$ & $1,139 \pm 0,1758$ \\
\hline 5HT & $2136 \pm 521,7$ & $2086 \pm 262,1$ & $899,4 \pm 145,7$ & $1333 \pm 341,8^{*}$ & $675,8 \pm 80,01$ & $662,4 \pm 41,02$ \\
\hline 5HIAA & $1313 \pm 229,8$ & $1363 \pm 229,6$ & $428,4 \pm 85,69$ & $587,6 \pm 207,7^{*}$ & $597,1 \pm 32,66$ & $601,4 \pm 45,72$ \\
\hline SHIAA/5HT & $0,6339 \pm 0,1243$ & $0,5936 \pm 0,2321$ & $0,3919 \pm 0,1984$ & $0,463 \pm 0,09382$ & $0,8721 \pm 0,1935$ & $0,8838 \pm 0,1476$ \\
\hline
\end{tabular}

Notas: Os dados representam a media \pm desvio padrão em ng $/ \mathrm{ml}$

* estatisticamente diferente do controle (CAS) para $\mathrm{p} \leq 0,05, \mathrm{n}=10$ animais, teste " $\mathrm{t}$ " de Student para os dados paramétricos e teste"U" de Mann Whitney para dados não paramétricos.

$\mathrm{CAS}=$ animais que conviveram com outros tratados com PBS.

CAD- animais que conviveram com outros inoculados com o tumor de Ehrlich na forma ascética.

Os traços contínuos indicam valores abaixo do limite de detecção da metodologia.

Figura 46- Efeitos da convivência por 11 dias com portadores de um tumor ascítico de Ehrlich, sobre os níveis de Noradrenalina no Hipotálamo e Córtex Frontal

Hipotálamo NOR

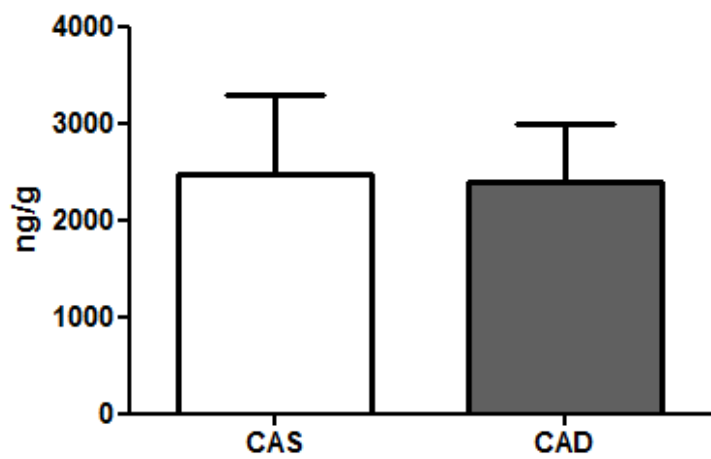

Córtex NOR

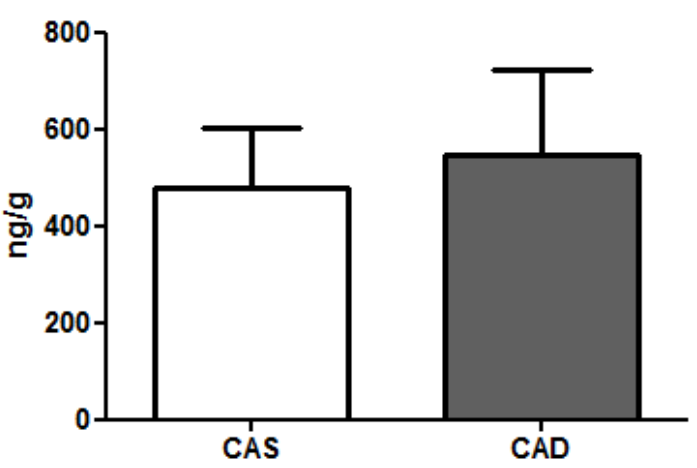

Legenda: $\mathrm{CAS}=$ companheiros dos animais injetados com PBS; $\mathrm{CAD}=$ companheiros dos animais inoculados com o tumor ascítico de Ehrlich. Os dados representam a média \pm o desvio padrão de 10 animais por grupo, $\mathrm{p}>0,05$ (teste "t" de Student) 
Figura 47- Efeitos da convivência por 11 dias com portadores de um tumor ascítico de Ehrlich, sobre os níveis de Noradrenalina no Bulbo

\section{Bulbo NOR}

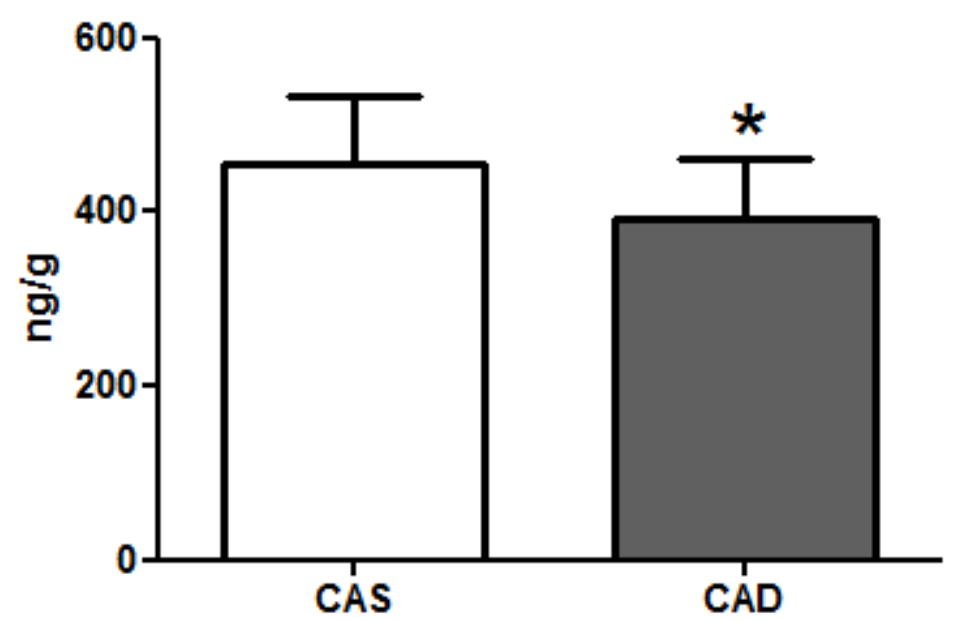

Legenda: $\mathrm{CAS}=$ companheiros dos animais injetados com PBS; CAD= companheiros dos animais inoculados com o tumor ascítico de Ehrlich. Os dados representam a média \pm o desvio padrão de 10 animais por grupo, $\mathrm{p} \leq 0,05$ (teste " $\mathrm{t}$ " de Student)

Figura 48- Efeitos da convivência por 11 dias com portadores de um tumor ascítico de Ehrlich, sobre os níveis do metabólito da Noradrenalina VMA no Córtex Frontal

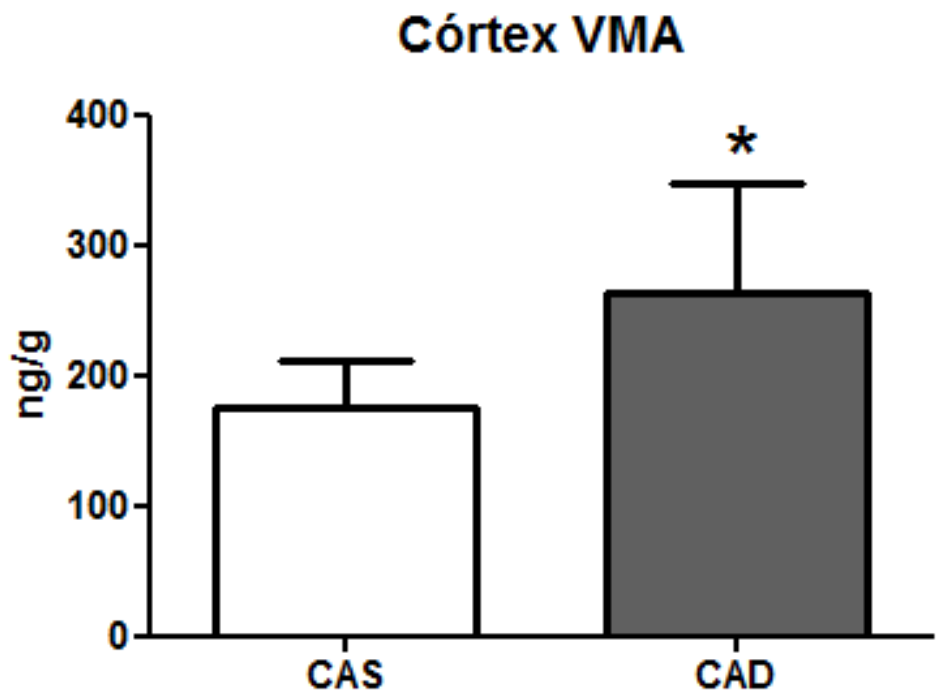

Legenda: CAS = companheiros dos animais injetados com PBS; CAD= companheiros dos animais inoculados com o tumor ascítico de Ehrlich. Os dados representam a média \pm o desvio padrão de 10 animais por grupo, $\mathrm{p} \leq 0,05$ (teste Mann Whitney) 
Figura 49- Efeitos da convivência por 11 dias com portadores de um tumor ascítico de Ehrlich, sobre os níveis do metabólito da Noradrenalina VMA no Bulbo

\section{Bulbo VMA}

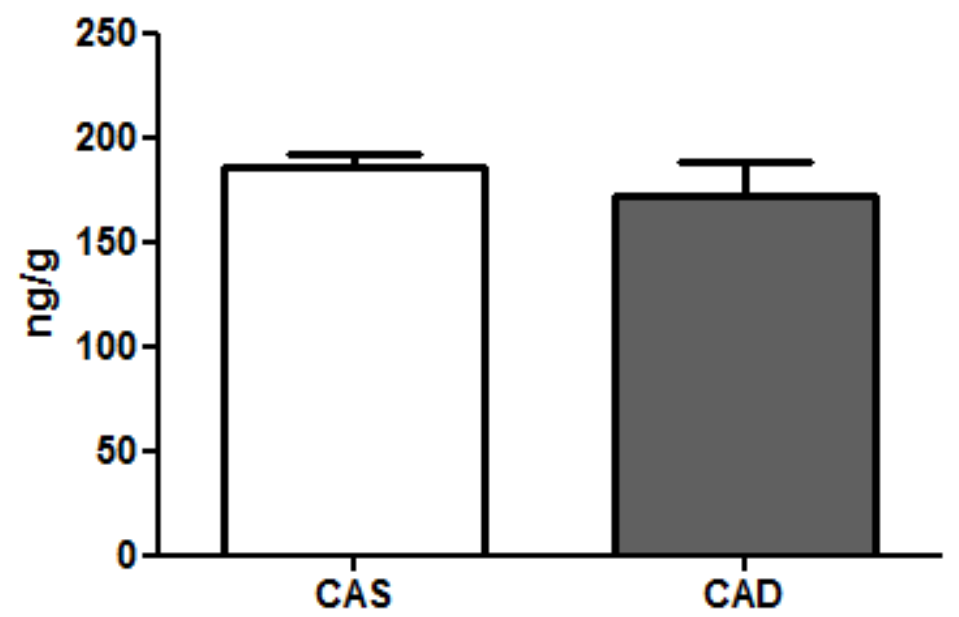

Legenda: CAS = companheiros dos animais injetados com PBS; CAD= companheiros dos animais inoculados com o tumor ascítico de Ehrlich. Os dados representam a média \pm o desvio padrão de 10 animais por grupo, $\mathrm{p}>0,05$ (teste " $\mathrm{t}$ " de Student)

Figura 50- Efeitos da convivência por 11 dias com portadores de um tumor ascítico de Ehrlich, sobre o "turnover" da Noradrenalina no Córtex Frontal

\section{Córtex VMA/NOR}

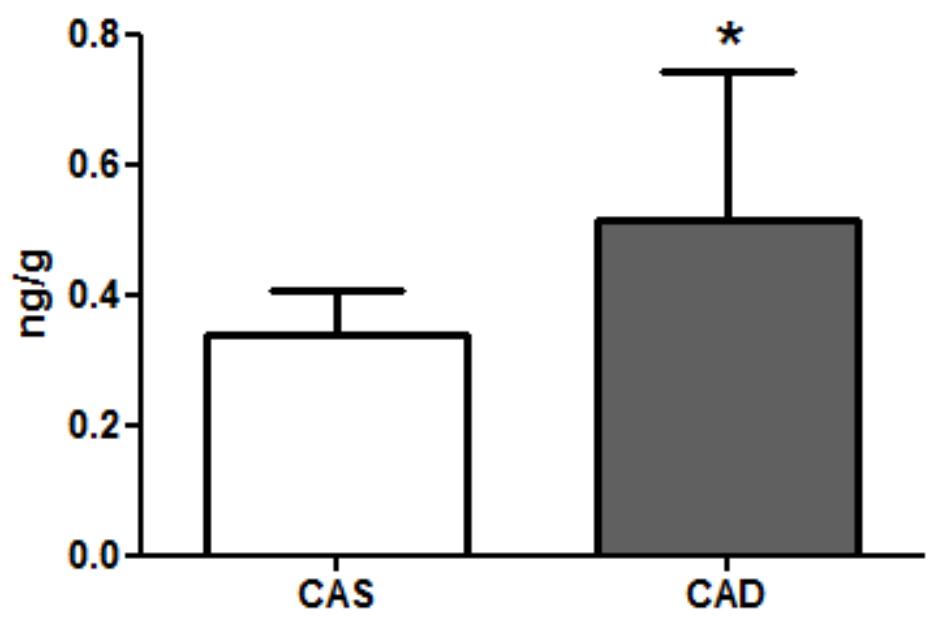

Legenda: $\mathrm{CAS}=$ companheiros dos animais injetados com PBS; CAD= companheiros dos animais inoculados com o tumor ascítico de Ehrlich. Os dados representam a média \pm o desvio padrão de 10 animais por grupo, $\mathrm{p} \leq 0,05$ (teste Mann Whitney) 
Figura 51- Efeitos da convivência por 11 dias com portadores de um tumor ascítico de Ehrlich, sobre o "turnover" da Noradrenalina no Bulbo

\section{Bulbo VMA/NOR}

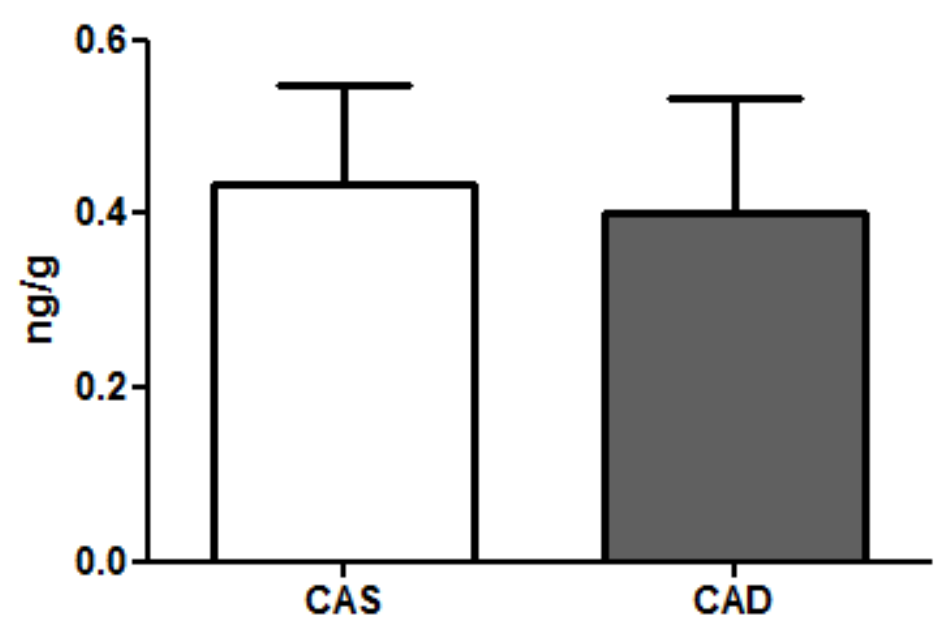

Legenda: $\mathrm{CAS}=$ companheiros dos animais injetados com PBS; CAD = companheiros dos animais inoculados com o tumor ascítico de Ehrlich. Os dados representam a média \pm o desvio padrão de 10 animais por grupo, $p>0,05$ (teste " $t$ " de Student)

Figura 52- Efeitos da convivência por 11 dias com portadores de um tumor ascítico de Ehrlich, sobre os níveis de Dopamina no Hipotálamo, Córtex Frontal e Bulbo
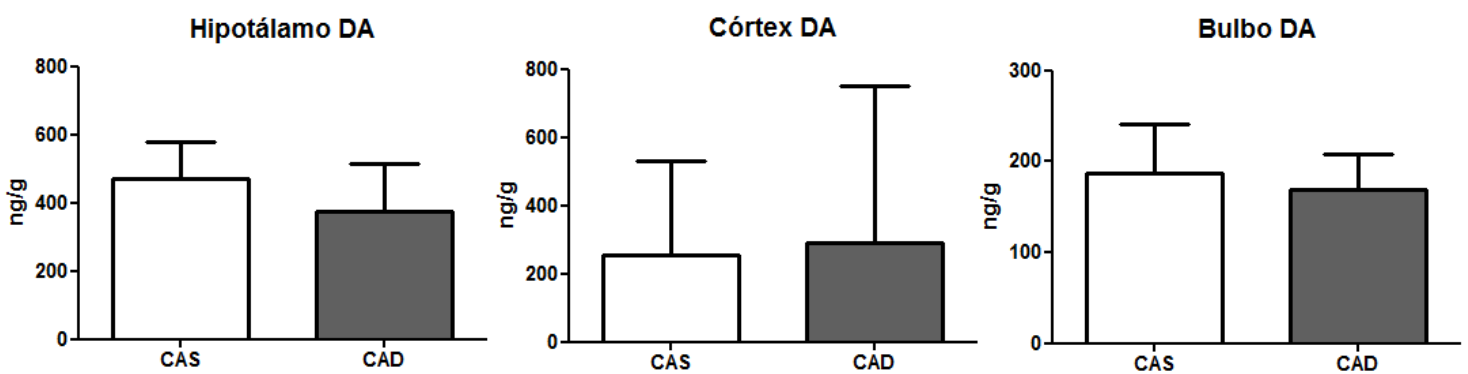

Legenda: $\mathrm{CAS}=$ companheiros dos animais injetados com PBS; $\mathrm{CAD}=$ companheiros dos animais inoculados com o tumor ascítico de Ehrlich. Os dados representam a média \pm o desvio padrão de 10 animais por grupo, $p>0,05$ (teste " $t$ " de Student) 
Figura 53- Efeitos da convivência por 11 dias com portadores de um tumor ascítico de Ehrlich, sobre os níveis do metabólito da Dopamina HVA no Hipotálamo e Bulbo

Hipotálamo HVA

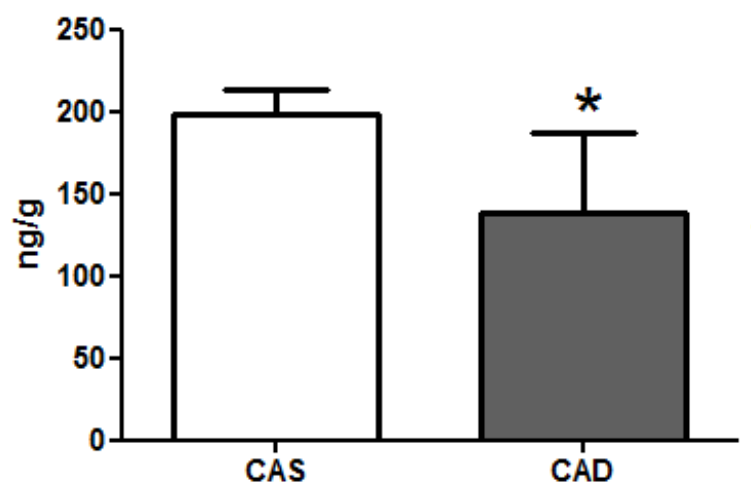

\section{Bulbo HVA}

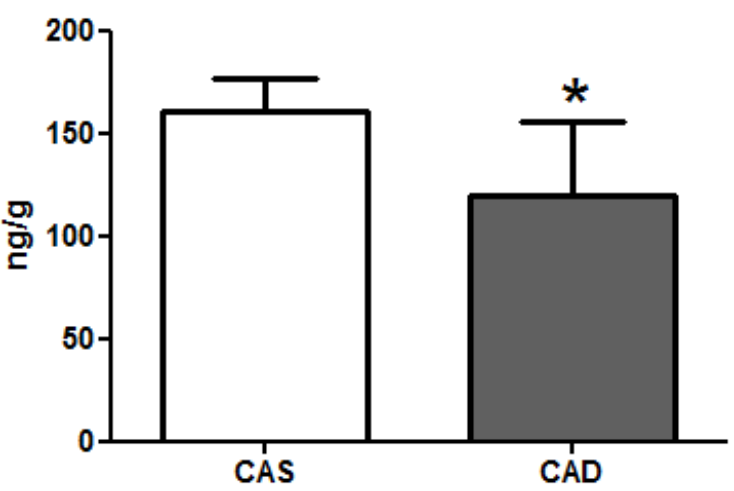

Legenda: $\mathrm{CAS}=$ companheiros dos animais injetados com PBS; $\mathrm{CAD}=$ companheiros dos animais inoculados com o tumor ascítico de Ehrlich. Os dados representam a média \pm o desvio padrão de 10 animais por grupo, $\mathrm{p} \leq 0,05$ (teste Mann Whitney) para os resultados no hipotálamo e $\mathrm{p} \leq 0,05$ (teste " $\mathrm{t}$ " de Student) para os resultados no Bulbo

Figura 54- Efeitos da convivência por 11 dias com portadores de um tumor ascítico de Ehrlich, sobre os níveis do metabólito da Dopamina HVA no Córtex Frontal

\section{Córtex HVA}

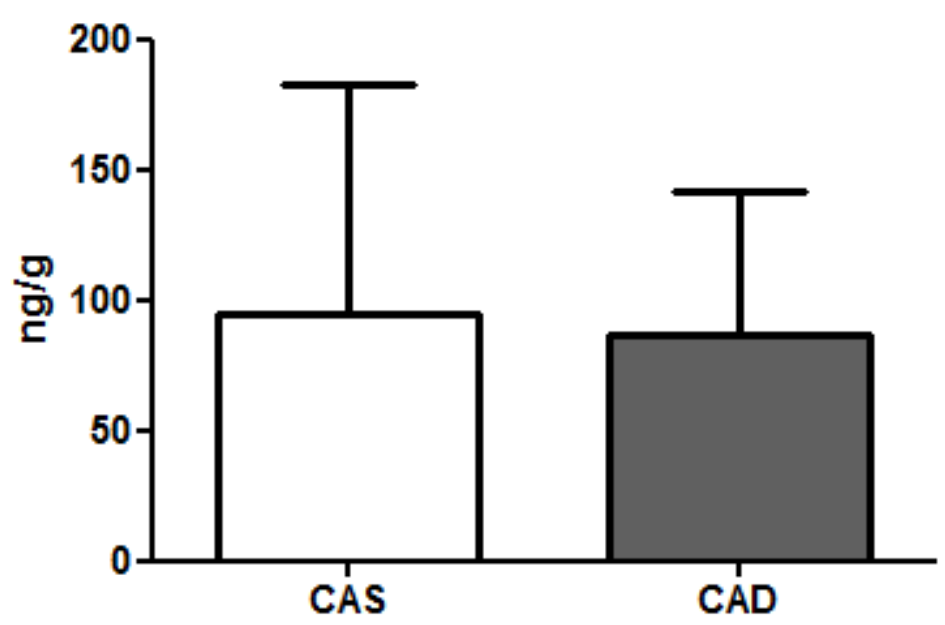

Legenda: $\mathrm{CAS}=$ companheiros dos animais injetados com PBS; $\mathrm{CAD}=$ companheiros dos animais inoculados com o tumor ascítico de Ehrlich. Os dados representam a média \pm o desvio padrão de 10 animais por grupo, $p>0,05$ (teste " $t$ " de Student) 
Figura 55- Efeitos da convivência por 11 dias com portadores de um tumor ascítico de Ehrlich, sobre os níveis do metabólito da Dopamina DOPAC no Hipotálamo, Córtex Frontal e Bulbo
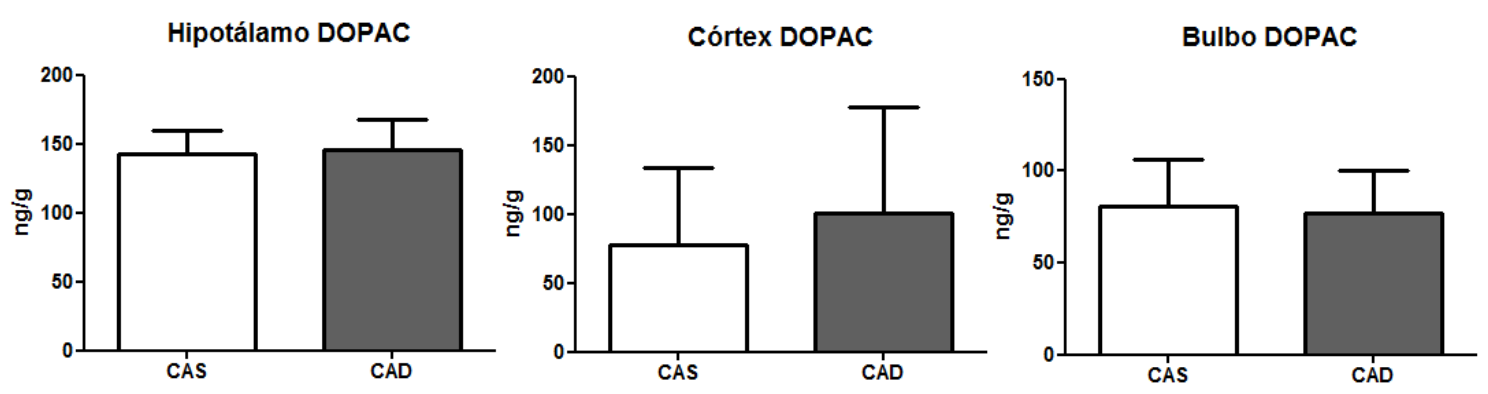

Legenda: $\mathrm{CAS}=$ companheiros dos animais injetados com PBS; $\mathrm{CAD}=$ companheiros dos animais inoculados com o tumor ascítico de Ehrlich. Os dados representam a média \pm o desvio padrão de 10 animais por grupo, $\mathrm{p}>0,05$ (teste " $\mathrm{t}$ " de Student)

Figura 56- Efeitos da convivência por 11 dias com portadores de um tumor ascítico de Ehrlich, sobre o "turnover" da Dopamina no Hipotálamo, Córtex Frontal e Bulbo
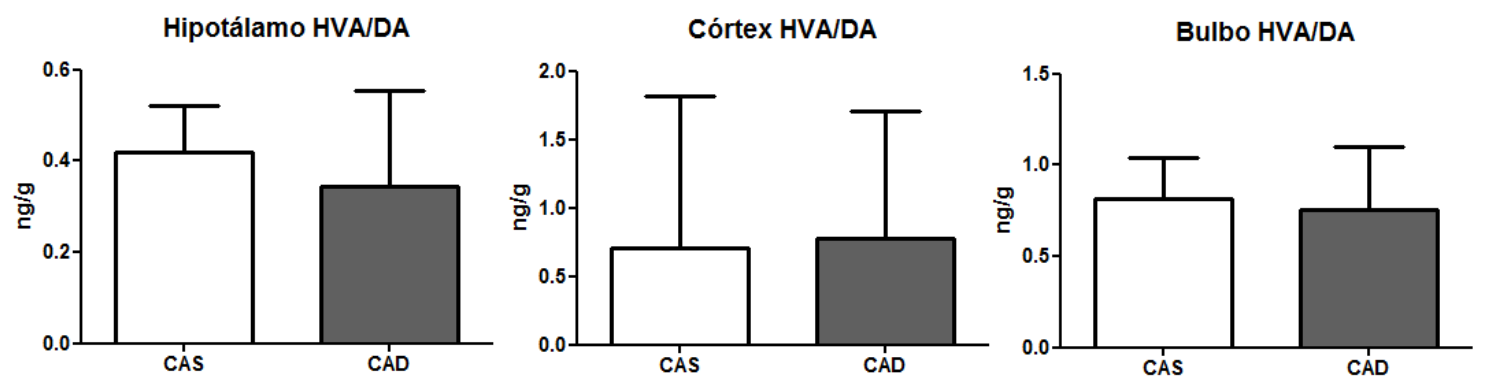

Legenda: $\mathrm{CAS}=$ companheiros dos animais injetados com PBS; $\mathrm{CAD}=$ companheiros dos animais inoculados com o tumor ascítico de Ehrlich. Os dados representam a média \pm o desvio padrão de 10 animais por grupo, $\mathrm{p}>0,05$ (teste " $\mathrm{t}$ " de Student)

Figura 57- Efeitos da convivência por 11 dias com portadores de um tumor ascítico de Ehrlich, sobre o "turnover" da Dopamina no Hipotálamo, Córtex Frontal e Bulbo
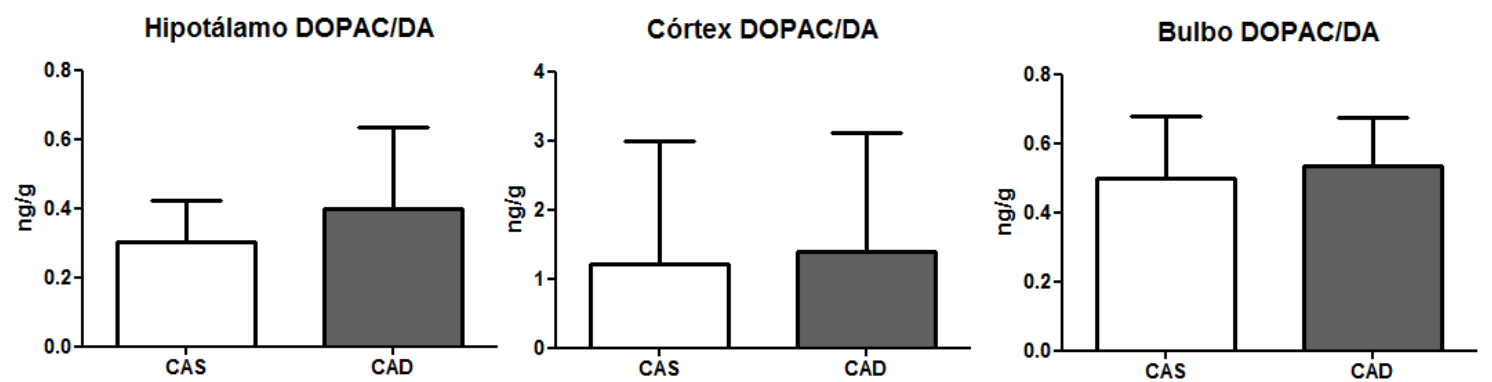

Legenda: $\mathrm{CAS}=$ companheiros dos animais injetados com PBS; CAD $=$ companheiros dos animais inoculados com o tumor ascítico de Ehrlich. Os dados representam a média \pm o desvio padrão de 10 animais por grupo, $p>0,05$ (teste " $t$ " de Student) para resultados no Hipotálamo e Bulbo e p>0,05 (teste Mann Whitney) para resultados em Córtex Frontal 
Figura 58- Efeitos da convivência por 11 dias com portadores de um tumor ascítico de Ehrlich, sobre o "turnover" da Dopamina no Hipotálamo, Córtex Frontal e Bulbo
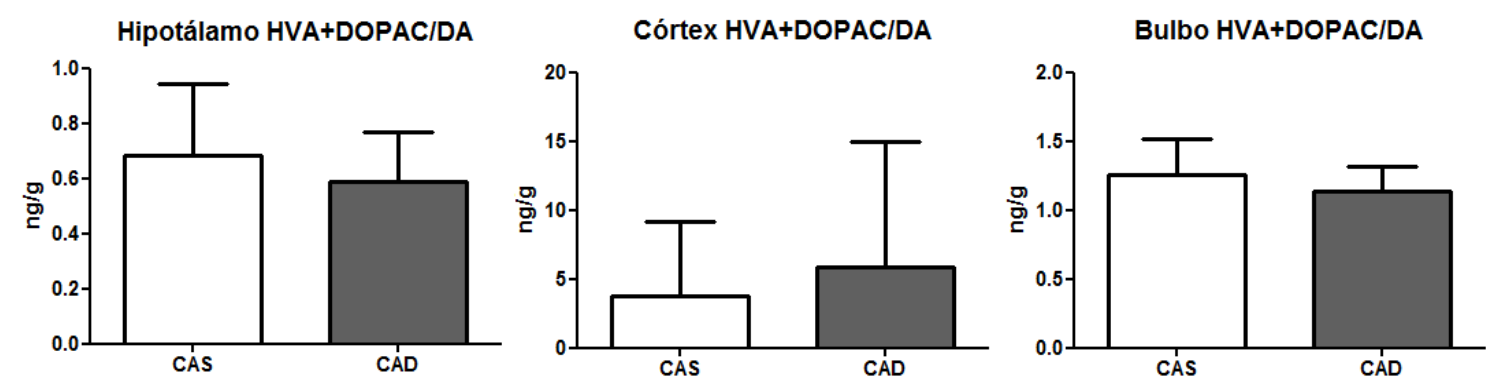

Legenda: CAS = companheiros dos animais injetados com PBS; CAD= companheiros dos animais inoculados com o tumor ascítico de Ehrlich. Os dados representam a média \pm o desvio padrão de 10 animais por grupo, $p>0,05$ (teste " $t$ " de Student) para resultados no Hipotálamo e Bulbo e p>0,05 (teste Mann Whitney) para resultados em Córtex Frontal

Figura 59- Efeitos da convivência por 11 dias com portadores de um tumor ascítico de Ehrlich, sobre os níveis de Serotonina no Hipotálamo e Bulbo

Hipotálamo 5HT

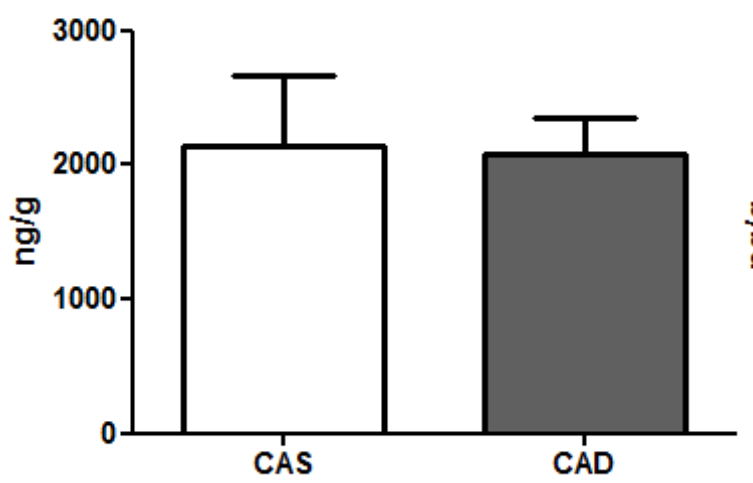

\section{Bulbo 5HT}

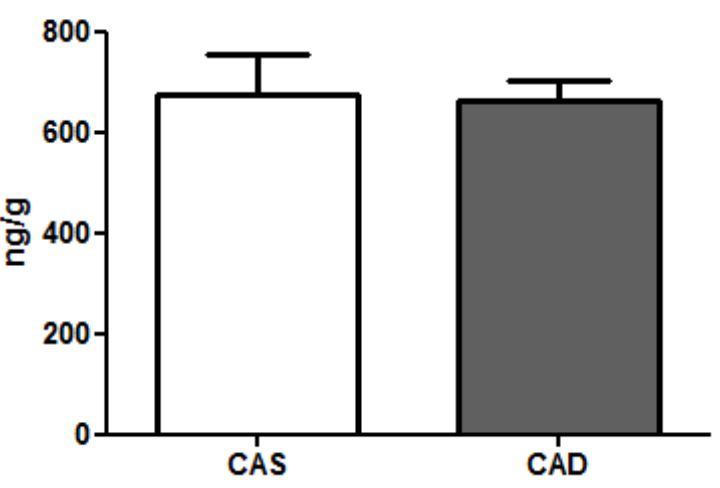

Legenda: $\mathrm{CAS}=$ companheiros dos animais injetados com PBS; $\mathrm{CAD}=$ companheiros dos animais inoculados com o tumor ascítico de Ehrlich. Os dados representam a média \pm o desvio padrão de 10 animais por grupo, $\mathrm{p}>0,05$ (teste " $\mathrm{t}$ " de Student) para resultados no Bulvo $\mathrm{p}>0,05$ (teste Mann Whitney) para resultados no Hipotálamo 
Figura 60- Efeitos da convivência por 11 dias com portadores de um tumor ascítico de Ehrlich, sobre os níveis de Serotonina no Córtex Frontal

Cortex 5-HT

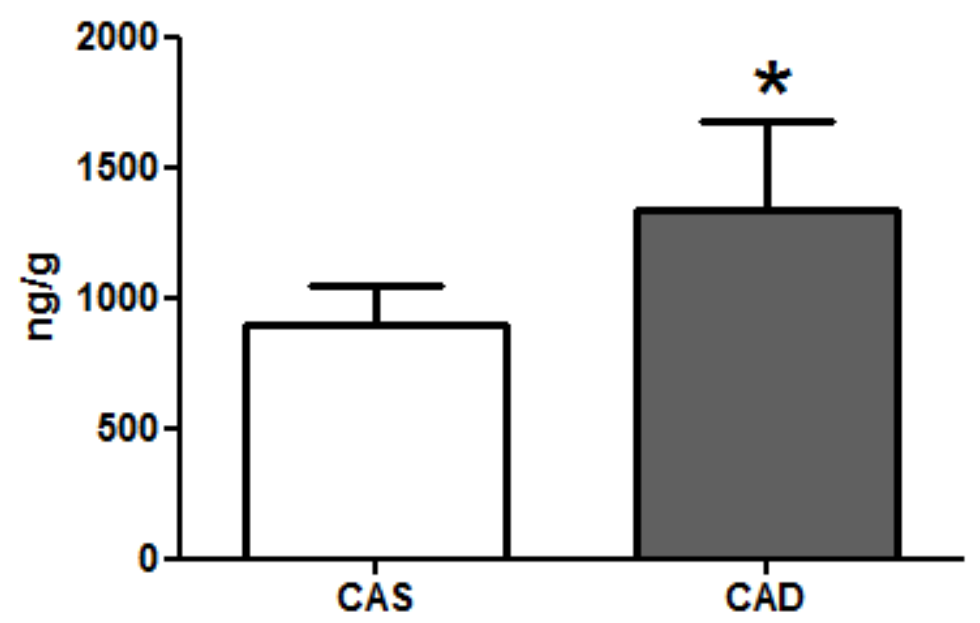

Legenda: $\mathrm{CAS}=$ companheiros dos animais injetados com PBS; CAD = companheiros dos animais inoculados com o tumor ascítico de Ehrlich. Os dados representam a média \pm o desvio padrão de 10 animais por grupo, $\mathrm{p} \leq 0,05$ (teste Mann Whitney)

Figura 61- Efeitos da convivência por 11 dias com portadores de um tumor ascítico de Ehrlich, sobre os níveis do metabólito da Serotonina 5HIAA no Hipotálamo e Bulbo

Hipotálamo 5HIAA

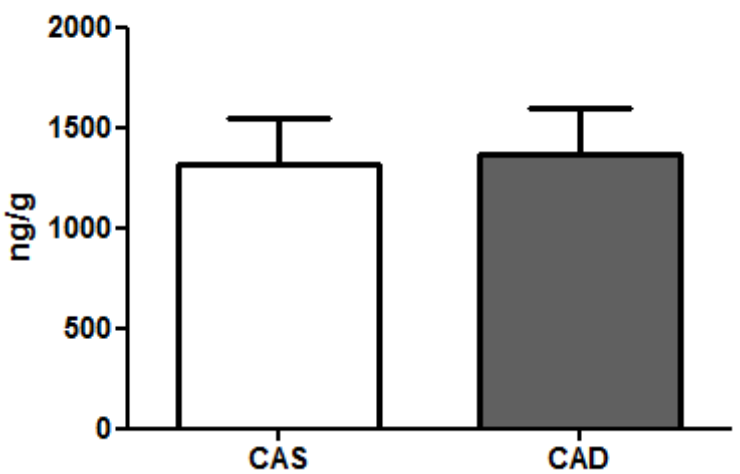

Bulbo 5HIAA

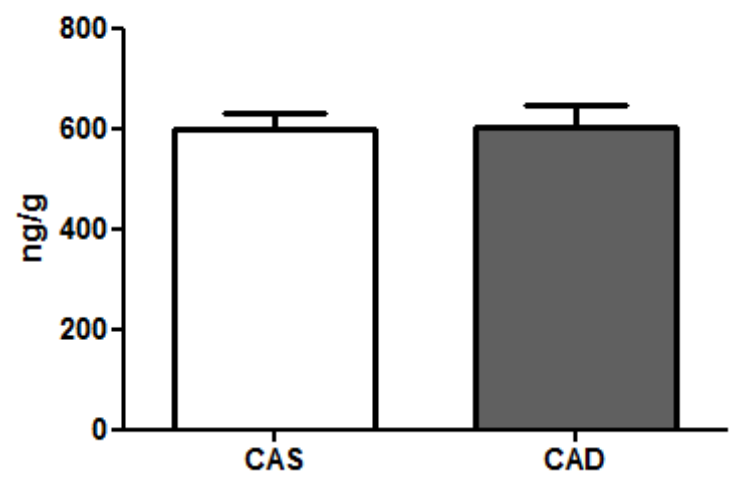

Legenda: CAS = companheiros dos animais injetados com PBS; CAD= companheiros dos animais inoculados com o tumor ascítico de Ehrlich. Os dados representam a média \pm o desvio padrão de 10 animais por grupo, $p>0,05$ (teste " $t$ " de Student) 
Figura 62- Efeitos da convivência por 11 dias com portadores de um tumor ascítico de Ehrlich, sobre os níveis do metabólito da Serotonina 5HIAA no Córtex Frontal

\section{Córtex 5HIAA}

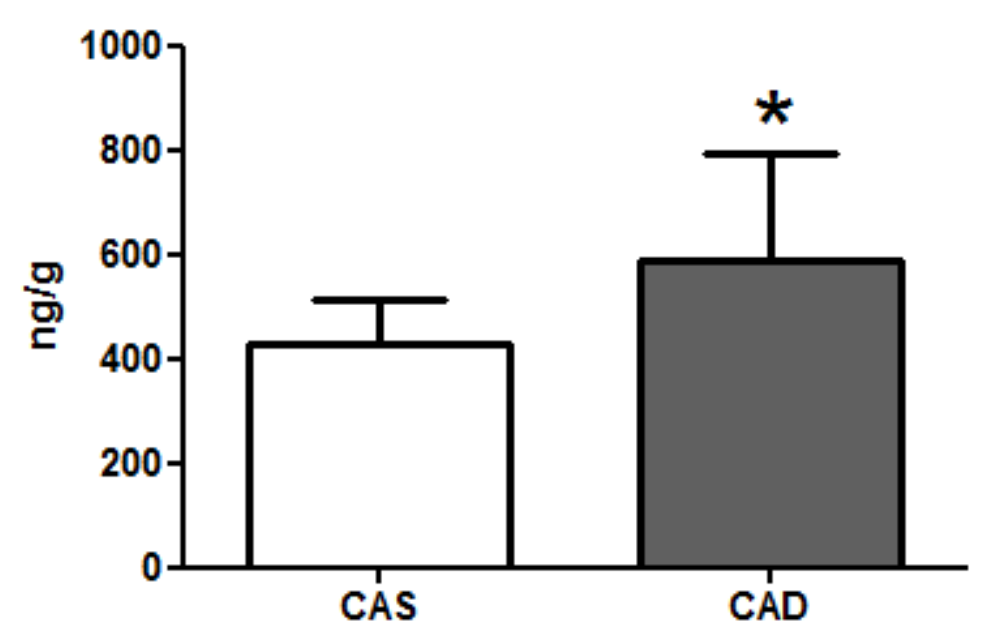

Legenda: $\mathrm{CAS}=$ companheiros dos animais injetados com PBS; CAD= companheiros dos animais inoculados com o tumor ascítico de Ehrlich. Os dados representam a média \pm o desvio padrão de 10 animais por grupo, $\mathrm{p} \leq 0,05$ (teste Mann Whitney)

Figura 63- Efeitos da convivência por 11 dias com portadores de um tumor ascítico de Ehrlich, sobre o "turnover" da Serotonina no Hipotálamo, Córtex Frontal e Bulbo
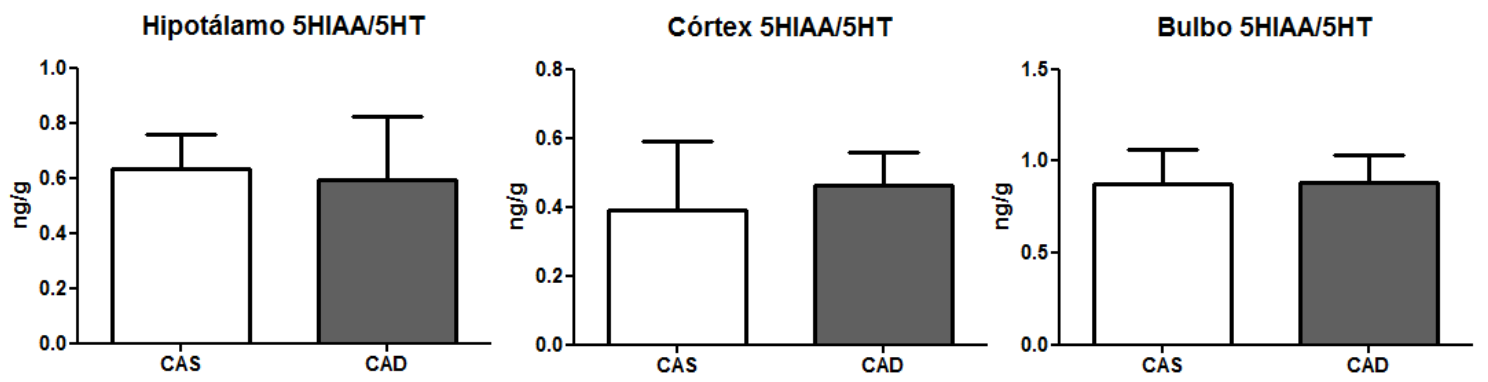

Legenda: $\mathrm{CAS}=$ companheiros dos animais injetados com PBS; CAD= companheiros dos animais inoculados com o tumor ascítico de Ehrlich. Os dados representam a média \pm o desvio padrão de 10 animais por grupo, $\mathrm{p}>0,05$ (teste " $\mathrm{t}$ ” de Student) para resultados no Hipotálamo e Bulbo e p>0,05 (teste Mann Whitney) para resultados em Córtex Frontal 
5.8 EXPERIMENTO 8- EXPRESSÃO DE CITOCINAS (IFN- $\gamma$, IL-12, IL-10, IL-6 E TNF$\alpha)$ NO BAÇO NO $11^{\circ}$ DIA DE CONVIVÊNCIA COM O DOENTE

Conforme descrito no item 4.2., foram utilizados 50 camundongos os quais foram separados em pares, de acordo com o peso corporal em dois grupos: um grupo controle e um grupo experimental. No dia (0) do experimento um camundongo de cada par controle foi inoculado com PBS i.p. e um camundongo de cada par experimental foi inoculado com células do tumor de Ehrlich ( $5 \times 10^{6}$ céls/animal) i.p. No $11^{\circ}$ dia de convivência foi coletado o baço dos animais companheiros dos inoculados com PBS (CAS) ou tumor de Ehrlich (CAD) para análise dos níveis de citocinas em esplenócitos como descrito no item 4.11.

\section{Resultados}

A análise estatística mostrou que a convivência por 11 dias com um companheiro doente aumentou os níveis das citocinas TNF- $\alpha$, IFN- $\gamma$ e IL-6 após 24 horas de incubação com LPS ( $\mathrm{p} \leq 0,05)$ como ilustram as figuras 64, 65 e 66 respectivamente; mostrou, também, um aumento de TNF- $\alpha$ e IL-6 após 48 horas de incubação com LPS ( $\leq 00,05)$ como ilustram as figuras 67 e 68 . Porém não se observaram diferenças estatísticas nos níveis de IFN- $\gamma$ e IL10 após 48 horas de incubação ( $p>0,05)$ como ilustram as figuras 69 e 70 respectivamente. Não se detectou IL-12 em nenhum dos períodos e grupos e IL-10 do grupo CAS 24 horas após incubação (dados não apresentados). 
Figura 64- Efeitos da convivência por 11 dias com portadores do tumor ascítico de Ehrlich sobre os níveis de TNF- $\alpha 24$ horas após incubação com estímulo LPS dosada por CBA

TNF-alfa 24 hrs

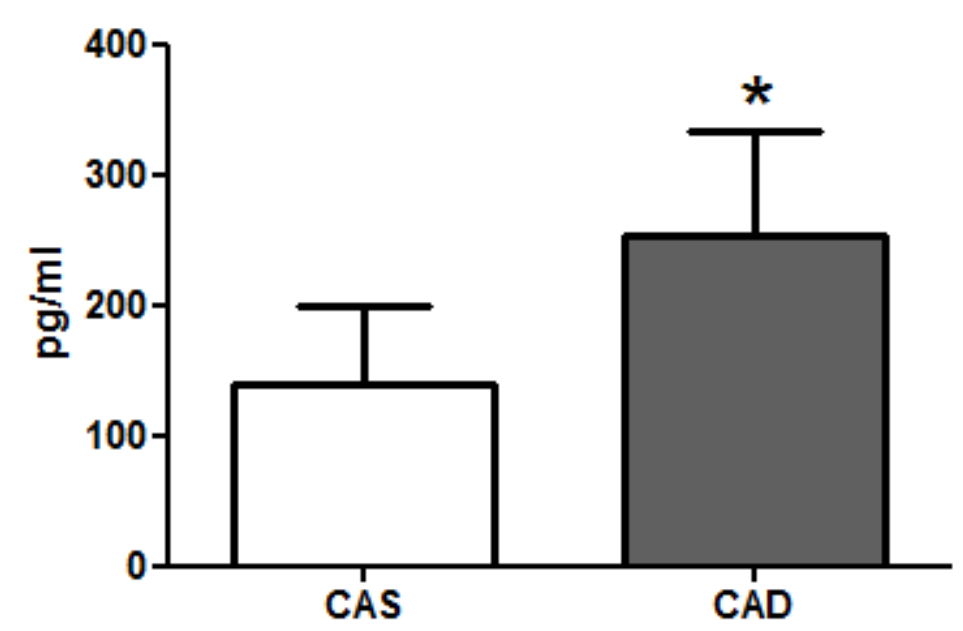

Legenda: $\mathrm{CAS}=$ companheiros dos animais injetados com PBS; CAD= companheiros dos animais inoculados com o tumor ascítico de Ehrlich. Os dados representam a média \pm o desvio padrão de 10 animais por grupo, $\mathrm{p} \leq 0,05$ (teste " $\mathrm{t}$ " de Student)

Figura 65- Efeitos da convivência por 11 dias com portadores do tumor ascítico de Ehrlich sobre os níveis de IFN- $\gamma 24$ horas após incubação com estímulo LPS dosada por CBA

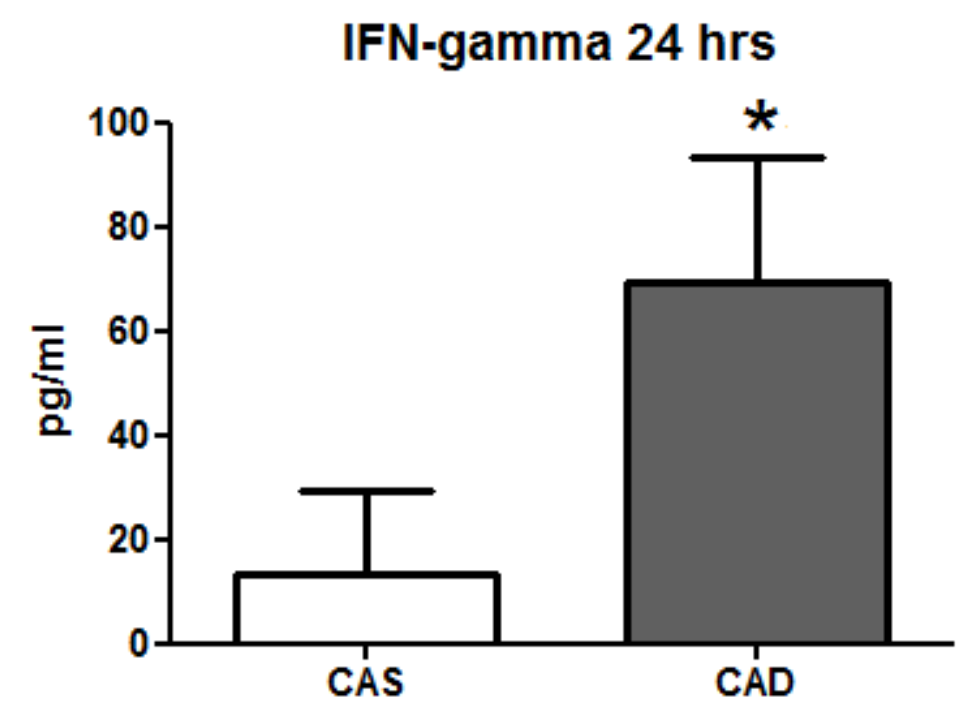

Legenda: $\mathrm{CAS}=$ companheiros dos animais injetados com PBS; CAD= companheiros dos animais inoculados com o tumor ascítico de Ehrlich. Os dados representam a média \pm o desvio padrão de 10 animais por grupo, $\mathrm{p} \leq 0,05$ (teste " $\mathrm{t}$ " de Student) 
Figura 66- Efeitos da convivência por 11 dias com portadores do tumor ascítico de Ehrlich sobre os níveis de IL-6 24 horas após incubação com estímulo LPS dosada por CBA

\section{IL-6 24hrs}

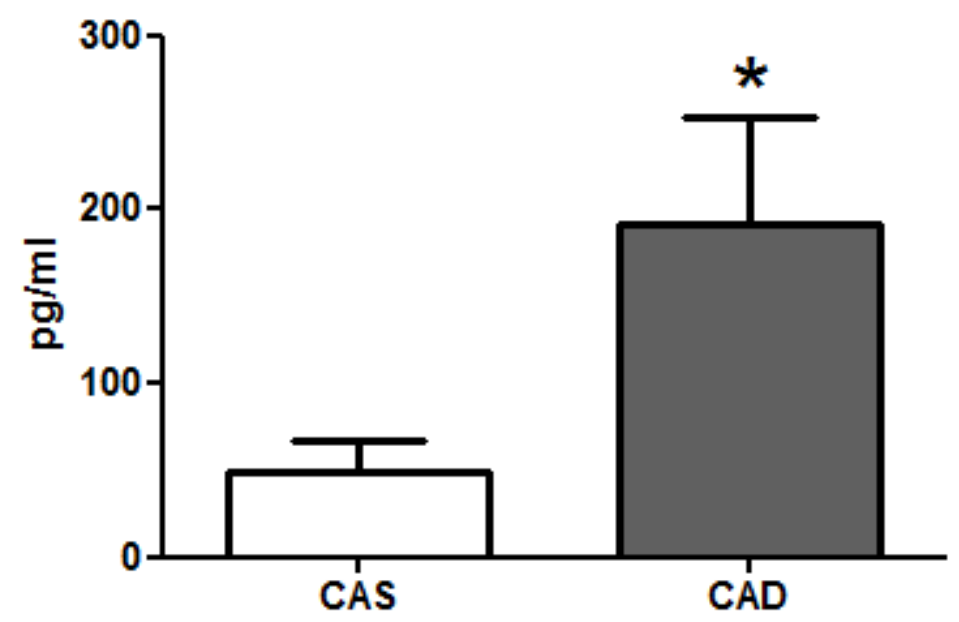

Legenda: $\mathrm{CAS}=$ companheiros dos animais injetados com PBS; CAD= companheiros dos animais inoculados com o tumor ascítico de Ehrlich. Os dados representam a média \pm o desvio padrão de 10 animais por grupo, $\leq \leq 0,05$ (teste Mann Whitney)

Figura 67- Efeitos da convivência por 11 dias com portadores do tumor ascítico de Ehrlich sobre os níveis de TNF- $\alpha 48$ horas após incubação com estímulo LPS dosada por CBA

\section{TNF-alfa 48hrs}

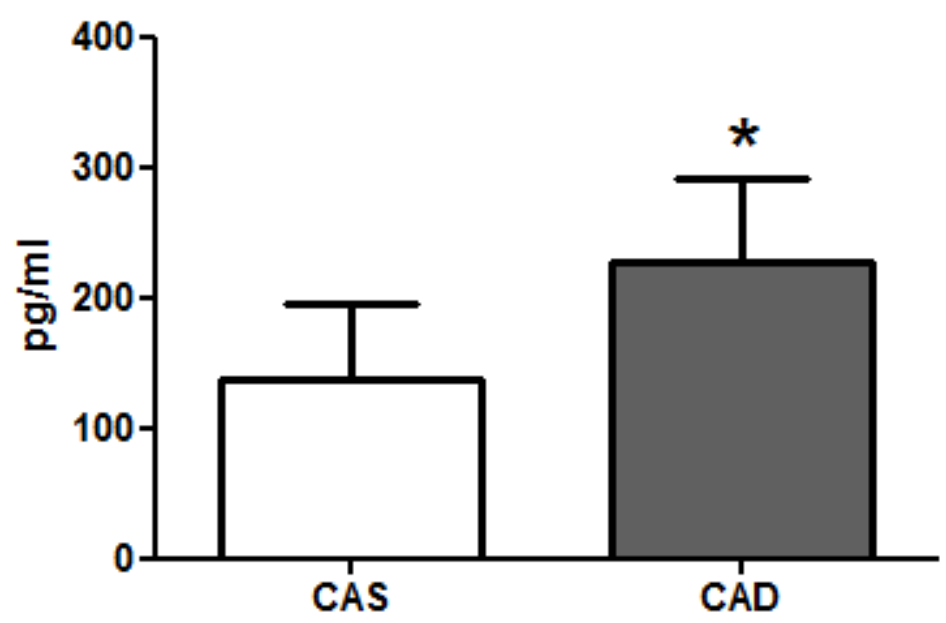

Legenda: $\mathrm{CAS}=$ companheiros dos animais injetados com PBS; CAD= companheiros dos animais inoculados com o tumor ascítico de Ehrlich. Os dados representam a média \pm o desvio padrão de 10 animais por grupo, $\mathrm{p} \leq 0,05$ (teste " $\mathrm{t}$ ” de Student) 
Figura 68- Efeitos da convivência por 11 dias com portadores do tumor ascítico de Ehrlich sobre os níveis de IL-6 48 horas após incubação com estímulo LPS dosada por CBA

\section{IL-6 48hrs}

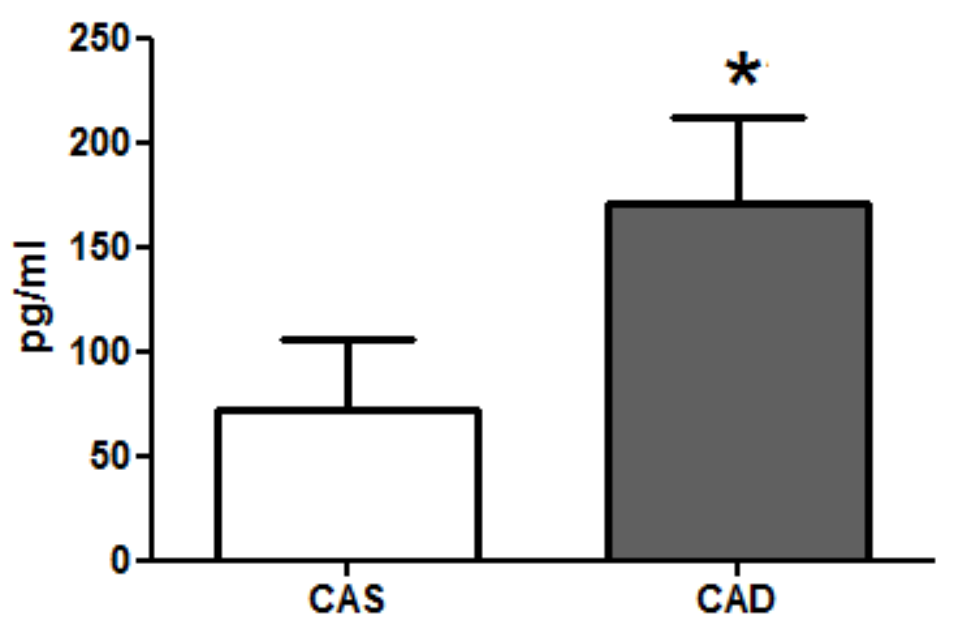

Legenda: $\mathrm{CAS}=$ companheiros dos animais injetados com PBS; CAD= companheiros dos animais inoculados com o tumor ascítico de Ehrlich. Os dados representam a média \pm o desvio padrão de 10 animais por grupo, $\mathrm{p} \leq 0,05$ (teste “t” de Student)

Figura 69- Efeitos da convivência por 11 dias com portadores do tumor ascítico de Ehrlich sobre os níveis de IFN- $\gamma 48$ horas após incubação com estímulo LPS dosada por CBA

\section{IFN-gamma $48 \mathrm{hrs}$}

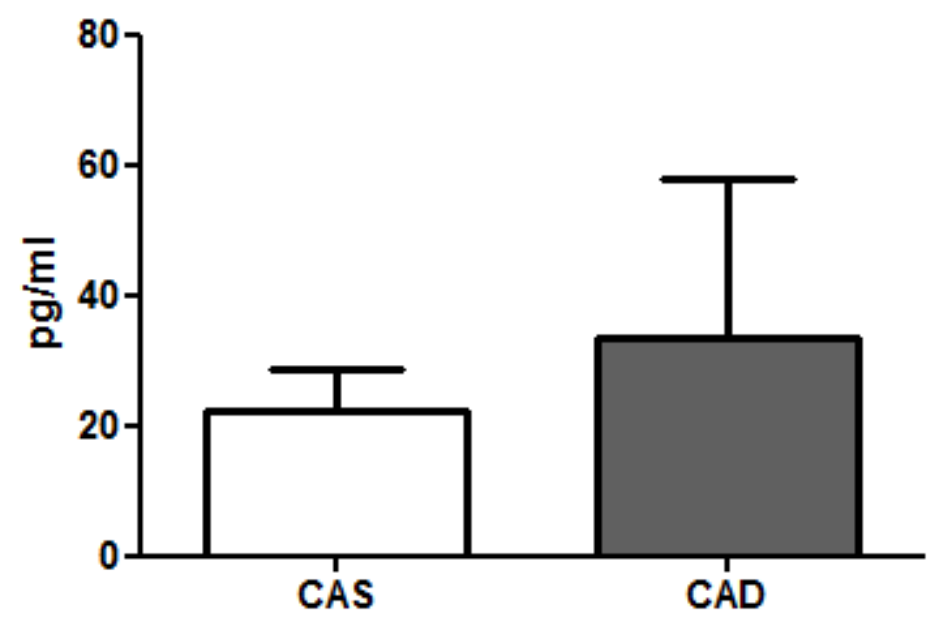

Legenda: $\mathrm{CAS}=$ companheiros dos animais injetados com PBS; CAD= companheiros dos animais inoculados com o tumor ascítico de Ehrlich. Os dados representam a média \pm o desvio padrão de 10 animais por grupo, p>0,05 (teste Mann Whitney) 
Figura 70- Efeitos da convivência por 11 dias com portadores do tumor ascítico de Ehrlich sobre os níveis de IL-10 48 horas após incubação com estímulo LPS dosada por CBA

\section{IL-10 48hrs}

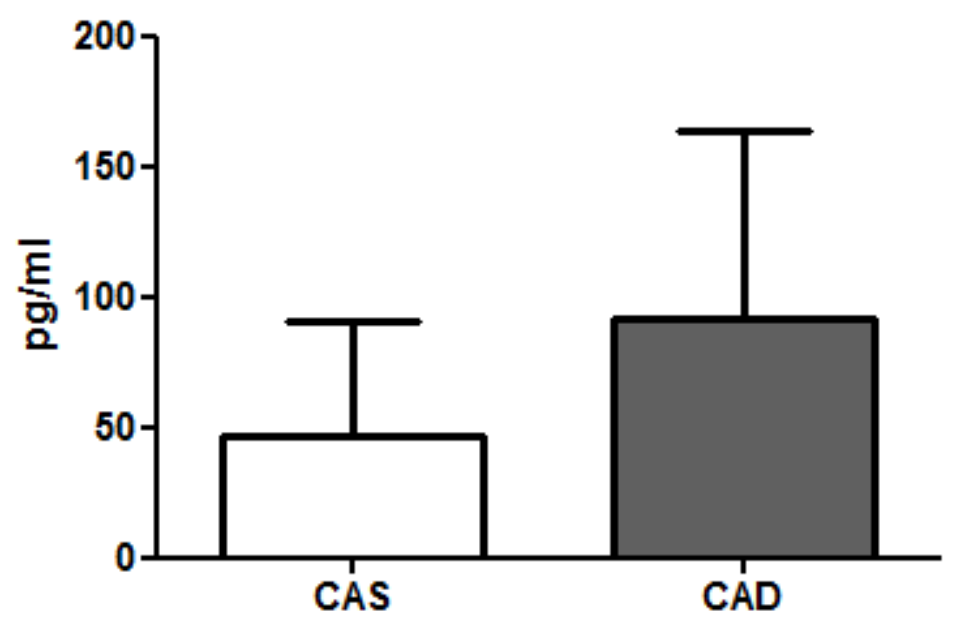

Legenda: $\mathrm{CAS}=$ companheiros dos animais injetados com PBS; CAD= companheiros dos animais inoculados com o tumor ascítico de Ehrlich. Os dados representam a média \pm o desvio padrão de 10 animais por grupo, $\mathrm{p}>0,05$ (teste " $\mathrm{t}$ " de Student)

5.9 EXPERIMENTO 9-EXPRESSÃO DE CITOCINAS (IL-1B, IL-6 E TNF- $\alpha$ ) NO HIPOTÁLAMO E CÓRTEX FRONTAL NO $11^{\circ}$ DIA DE CONVIVÊNCIA COM O DOENTE

Conforme descrito no item 4.2., foram utilizados 42 camundongos os quais foram separados em pares, de acordo com o peso corporal em dois grupos: um grupo controle e um grupo experimental. No dia (0) do experimento um camundongo de cada par controle foi inoculado com PBS i.p. e um camundongo de cada par experimental foi inoculado com células do tumor de Ehrlich $\left(5 \times 10^{6}\right.$ céls/animal) i.p. No $11^{\circ}$ dia de convivência os animais companheiros dos inoculados com PBS (CAS) ou tumor de Ehrlich (CAD) foram submetidos à eutanásia por decaptação e as estruturas do Sistema Nervoso Central foram coletadas como descrito no item 4.12. 


\section{Resultados}

Como ilustram as figuras 71, 72, 73, 74, 75 e 76, não foram observadas diferenças estatísticas significantes entre os grupos em relação a quaisquer dos parâmetros analisados $(\mathrm{p}>0,05)$.

Figura 71- Efeitos da convivência por 11 dias com portadores do tumor ascítico de Ehrlich sobre a expressão relativa de TNF- $\alpha$ no Hipotálamo

TNF Hipotálamo

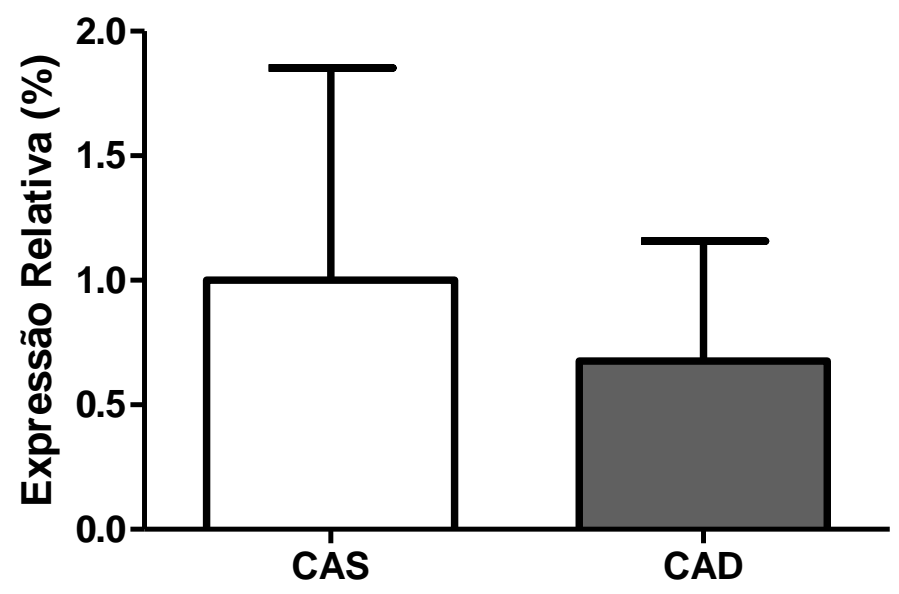

Legenda: CAS = companheiros dos animais injetados com PBS; CAD = companheiros dos animais inoculados com o tumor ascítico de Ehrlich. Os dados representam a média \pm o desvio padrão de 9 animais por grupo, p>0,05 (teste"t" de Student) 
Figura 72- Efeitos da convivência por 11 dias com portadores do tumor ascítico de Ehrlich sobre a expressão relativa de IL-1 no Hipotálamo

\section{IL-1 Hipotálamo}

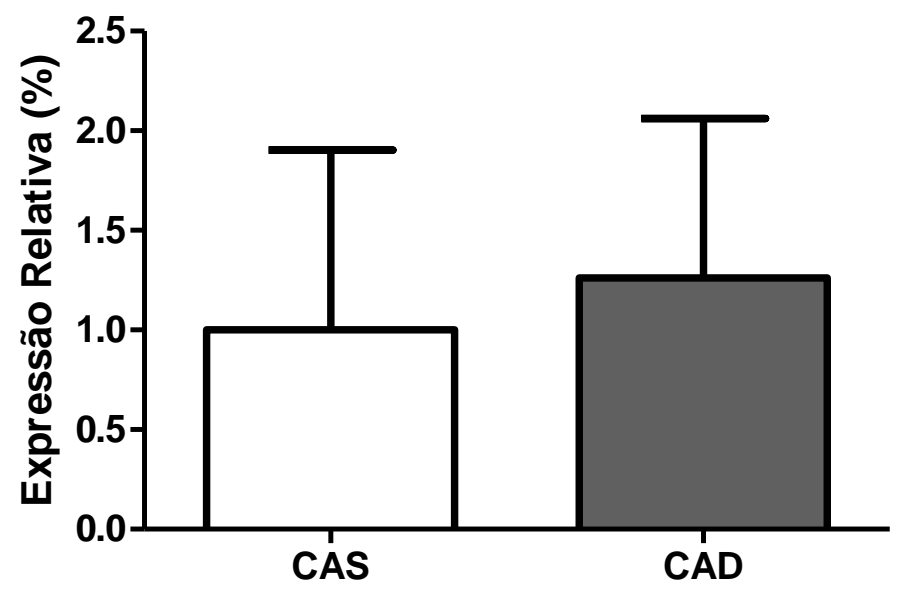

Legenda: $\mathrm{CAS}=$ companheiros dos animais injetados com PBS; CAD $=$ companheiros dos animais inoculados com o tumor ascítico de Ehrlich. Os dados representam a média \pm o desvio padrão de 9 animais por grupo, $\mathrm{p}>0,05$ (teste"t" de Student)

Figura 73- Efeitos da convivência por 11 dias com portadores do tumor ascítico de Ehrlich sobre a expressão relativa de IL-6 no Hipotálamo

\section{IL-6 Hipotálamo}

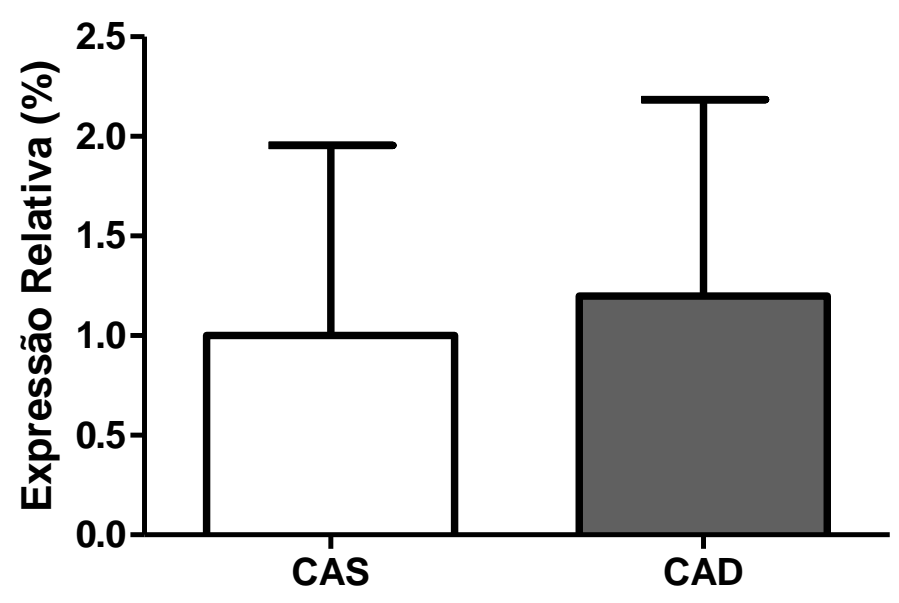

Legenda: $\mathrm{CAS}=$ companheiros dos animais injetados com PBS; $\mathrm{CAD}=$ companheiros dos animais inoculados com o tumor ascítico de Ehrlich. Os dados representam a média \pm o desvio padrão de 9 animais por grupo, p>0,05 (teste"t" de Student) 
Figura 74- Efeitos da convivência por 11 dias com portadores do tumor ascítico de Ehrlich sobre a expressão relativa de IL-1 no Córtex

\section{IL-1 Córtex}

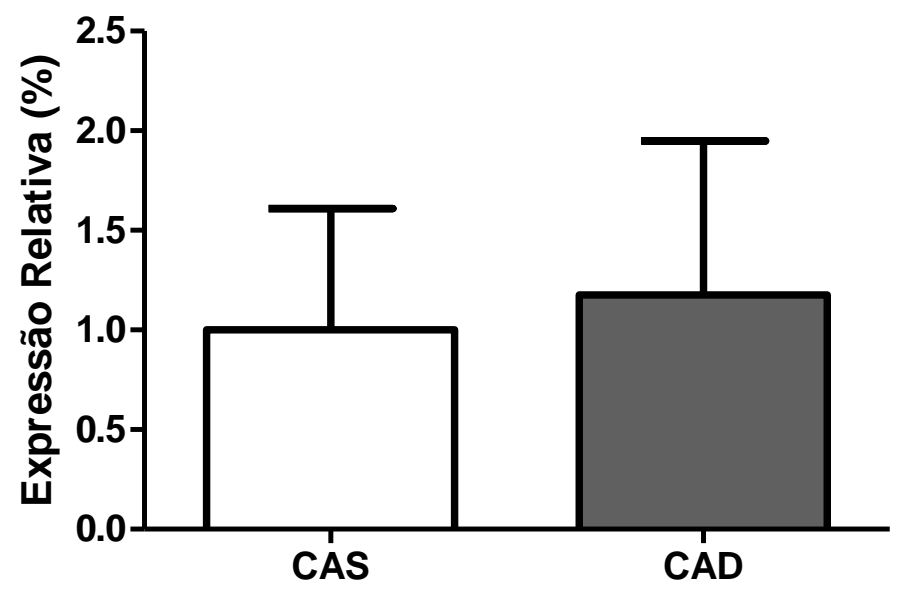

Legenda: $\mathrm{CAS}=$ companheiros dos animais injetados com PBS; CAD= companheiros dos animais inoculados com o tumor ascítico de Ehrlich. Os dados representam a média \pm o desvio padrão de 9 animais por grupo, $\mathrm{p}>0,05$ (teste “t” de Student)

Figura 75- Efeitos da convivência por 11 dias com portadores do tumor ascítico de Ehrlich sobre a expressão relativa de IL-6 no Córtex

\section{IL-6 Córtex}

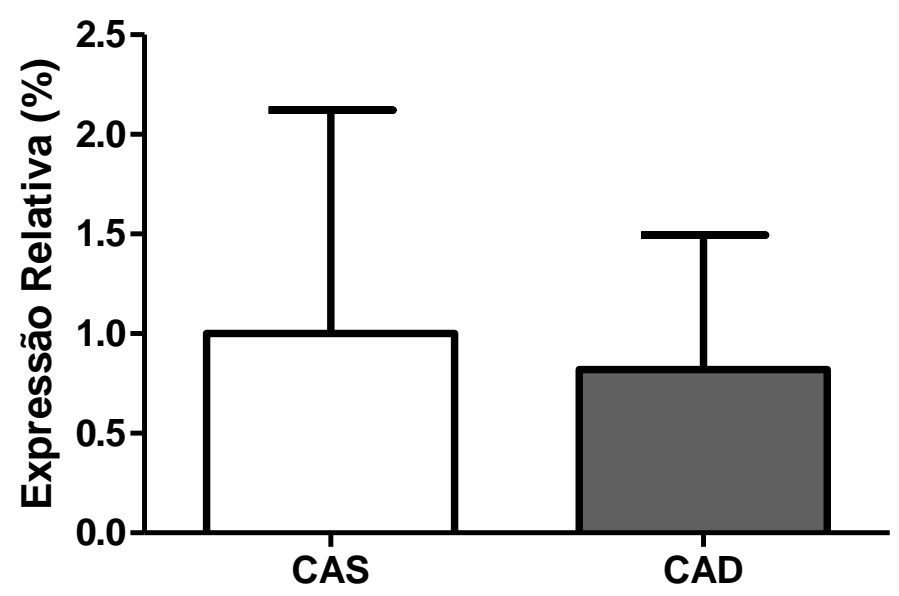

Legenda: $\mathrm{CAS}=$ companheiros dos animais injetados com PBS; CAD= companheiros dos animais inoculados com o tumor ascítico de Ehrlich. Os dados representam a média \pm o desvio padrão de 9 animais por grupo, $p>0,05$ (teste “t” de Student) 
Figura 76- Efeitos da convivência por 11 dias com portadores do tumor ascítico de Ehrlich sobre a expressão relativa de TNF- $\alpha$ no Córtex

TNF Córtex

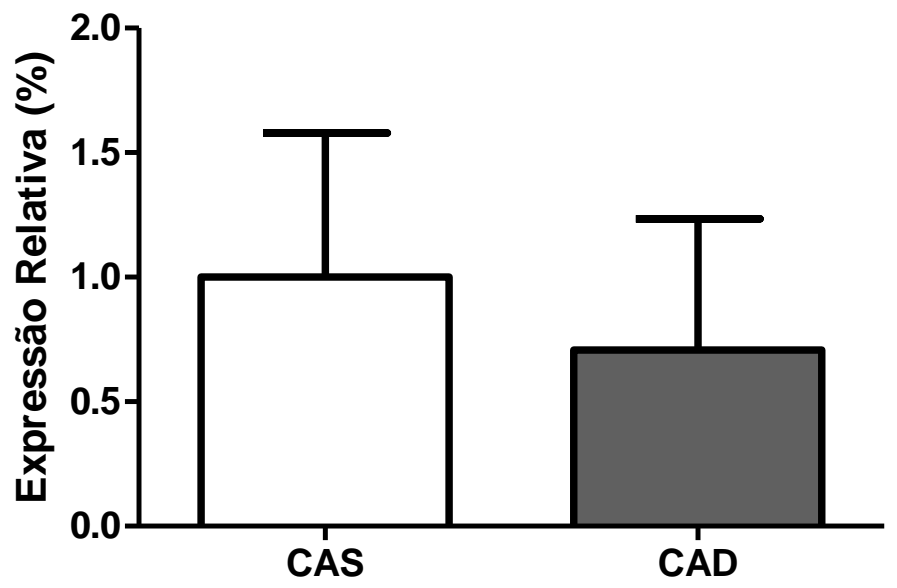

CAS = companheiros dos animais injetados com PBS; CAD = companheiros dos animais inoculados com o tumor ascítico de Ehrlich. Os dados representam a média \pm o desvio padrão de 9 animais por grupo,p>0,05 (teste"t'” de Student) 


\section{DISCUSSÃO}

Os resultados obtidos no presente trabalho reforçam a hipótese de que a convivência de animais saudáveis com companheiros doentes (animais inoculados com 5 x $10^{6}$ células do tumor ascítico de Ehrlich) pode desbalancear a resposta imune nos companheiros saudáveis, além de causar diferenças bioquímicas e comportamentais. Inúmeros resultados agora observados em machos corroboram com dados obtidos anteriormente por nosso grupo de pesquisa em fêmas (MORGULIS et al., 2004; ALVES et al., 2006; ALVES; VISMARI; PALERMO-NETO, 2007; ALVES; RIBEIRO; PALERMO-NETO, 2012). Entretanto, observamos diferenças nas respostas imunes, bioquímicas e comportamentais de camundongos machos companheiros em relação a resposta de camundongos fêmeas. Especificamente, a convivência por 11 dias de camundongos sadios machos com outro portador do tumor de Ehrlich mostrou: 1) Um aumento nos níveis de adrenalina e noradrenalina plasmática; 2) Diminuição do burst oxidativo de neutrófilos induzido por PMA; 3) Diminuição do burst oxidativo de neutrófilos induzidos por S. aureus; 4) Aumento da contagem de células do mesmo do mesmo tumor ascítico de Ehrlich inoculado nos companheiros 11 dias após a convivência; 5) Aumento da concentração de células do mesmo tumor ascítico de Ehrlich inoculados nos companheiros 11 dias após a convivência; 6) Diminuição dos níveis do metabólito da dopamina (HVA) no hipotálamo; 7) Aumento dos níveis do metabólito da noradrenalina (VMA) no córtex frontal; 8) Aumento do turnover e noradrenalina (VMA/NOR) no córtex frontal; 9) Aumento dos níveis de serotonina (5HT) no córtex frontal; 10) Aumento dos níveis do metabólito da serotonina (5HIAA) no córtex frontal; 11) Diminuição dos níveis de noradrenalina (NOR) no bulbo; 12) Diminuição dos níveis do metabólito da dopamina (HVA) no bulbo; 13) Aumento de TNF- $\alpha$, IFN- $\gamma$ e IL-6 após 24 horas em cultura de esplenócitos estimulados com LPS; 14) Aumento de TNF- $\alpha$ e IL6 após 48 horas em cultura de esplenócitos estimulados com LPS. No entanto, não foram observadas diferenças significantes: 15$)$ Nos níveis de corticosterona no $5^{\circ}, 7^{\circ}, 9^{\circ}$ e $11^{\circ}$ dias de convivência com o doente; 16) No peso relativo das glândulas adrenais; 17) Na intensidade de fagocitose de neutrófilos; 18) Na porcentagem de fagocitose de neutrófilos; 19) No volume de líquido ascítico dos companheiros inoculados com o mesmo tumor de Ehrlich após 11 dias de convivência; 20) Na expressão de IFN- $\gamma$ e IL-10 após 48 horas de cultura de esplenócitos estimulados com LPS; 21) Nenhuma alteração na expressão de citocinas (TNF- $\alpha$, IL-1 e IL$6)$. 
Sabe-se que a resposta imune durante o estresse vem sendo amplamente estudada no contexto de ativação do eixo HPA e/ou do Sistema Nervoso Autônomo Simpático (ADER; KELLEY, 2007; ALVES; PALERMO-NETO, 2007). O organismo sobrevive mantendo um complexo e dinâmico equilíbrio da homeostase, sendo que desafios ou perigos diariários podem desestruturar este equilíbrio tanto em pessoas como em animais (VIDRIH et al., 2012; MARCHETTI; PLUCHINO, 2013). Já esta bem elucidado na literatura a interação neuroimune que ocorre durante o estresse influenciando principalmente a atividade cerebral, o comportamento e a imunidade. Em humanos já foram relatadas mudanças no estado de saúde e no comportamento dos "caregivers" (pessoas que cuidam de outras doentes) em função da vivência com situações de estresse psicológico (MARCHI-JONES; MURPHY; ROUSSEAU, 1996; BELLIN et al., 2013). É indiscutível que animais, assim como humanos precisam de um relacionamento social saudável apresentando idênticas respostas perante estresses de natureza psicológicos (ASCHBACHER et al., 2013; OKA et al., 2013).

$\mathrm{O}$ ato de um animal acompanhar outro doente (portador de um tumor) leva a um estresse crônico e, consequentemente a alterações comportamentais, neuroquímicas e imunológicas como aumento de atividade motora, diminuição da imunidade inata, diminuição da resistência orgânica ao desenvolvimento de um tumor (MORGULIS et al., 2004; ALVES et al., 2006; ALVES; VISMARI; PALERMO-NETO, 2007; TOMIYOSHI et al., 2009). Comprovou-se ainda, que o odor liberado pelo animal doente é o responsável por todas estas alterações (ALVES et al., 2010; ALVES; RIBEIRO; PALERMO-NETO, 2012). Assim, a hipótese do atual trabalho foi avaliar a ação do eixo HPA assim como do SNAS nestas alterações neuroimunes utilizando os mesmos modelos experimentais, buscando avaliar se as alterações observadas em fêmeas também aconteceriam em camundongos machos. Tal pergunta sustenta-se na idéia, de que o dimorfismo sexual influencia respostas comportamentais e hormonais dos animais (KLEIN; JEDLICKA; PEKOSZ, 2010; RUBTSOV et al., 2010).

Assim como Morgulis et al. (2004) e Alves et al. (2006) não observamos alterações nos níveis séricos de corticosterona dos camundongos CAD comparados aos camundongos CAS. Até então, as análises realizadas por nosso grupo feitas apenas no último dia de convivência com o animal doente; no presente trabalho, fizemos análises seriadas da corticosterona com o intuito de verificar todas as fases e progressão de uma possível ativação do eixo HPA, uma vez que poderíamos em experimentos anteriores, não ter verificado algum tipo de alteração por termos realizado apenas uma coleta de sangue. Mesmo assim, coletando amostras de sangue nos $5^{\circ}, 7^{\circ}, 9^{\circ}$ e $11^{\circ}$ dias de convivência não observamos diferenças 
estatísticas significantes em qualquer das amostras analisadas. Para confirmar os dados, as glândulas adrenais foram pesadas e o peso relativo das mesmas foi calculado; não observamos também diferenças estatísticas entre os grupos. Com isso, confirmamos sugestão anterior de que as alterações neuroimunes apresentadas não dependem daação do eixo HPA, neste modelo de estresse. De relevância, estendemos esta afirmação para os machos. Entretanto, a ausência de mudanças nos níveis de corticosterona não exclui a presença de alterações na atividade deste eixo. Na verdade, diminuição dos níveis de ACTH, na presença de níveis semelhantes de corticosterona já foram relatados em camundongos submissos após o estresse por um confronto social (DE KLOET et al., 1991; BUGAJSKI, 1999; LIGHTMAN et al., 2002; ALVES et al., 2006; JAHNG, 2011). Desta forma, futuros experimentos com este modelo levarão ser direcionados ao estudo dos níveis plasmáticos de ACTH.

Dados de literatura apontam uma participação maior do SNAS na vigência de estresses de natureza psicológica (ALVES; RIBEIRO; PALERMO-NETO, 2012; HANKE et al., 2012; STROTH et al., 2013).

Analisando o Sistema Nervoso Autônomo Simpático, percebemos que a convivência com um companheiro doente por 11 dias aumentou os níveis de adrenalina e noradrenalina plasmática; dados estes semelhantes ao observados por Alves, Ribeiro e Palermo-Neto (2012) (ALVES; RIBEIRO; PALERMO-NETO, 2012). Sabe-se que este sistema é ativado em situações de estresse (STROTH et al., 2013) e que algumas fibras simpáticas estão em íntima conexão com órgão e células do sistema imune (MADDEN; FELTEN, 1995). Até pouco tempo atrás, as catecolaminas eram consideradas como moléculas imunossupressoras. Entretanto, sabe-se que hoje os efeitos das catecolaminas nas células do sistema imune é de modulação, isto é, podem ser estimulantes ou supressoras. O perfil deste efeito dependerá, dentre outros fatores, dos níveis destes neurotransmissores presentes em um dado momento na circulação sanguínea e/ou nos tecidos (ELENKOV et al., 2000). A noradrenalina pode modular a atividade celular por se ligar a receptores adrenérgicos em vários tipos celulares. $\mathrm{A}$ família dos $\beta$-adrenoceptores ( $\beta_{2} \mathrm{AR}$ ) contém três subtipos: $\beta_{1}, \beta_{2}$ e $\beta_{3}$ (KOHM; SANDERS, 2001), sendo quecélulas T, NK, monócitos CD14+ e células B expressam $\beta_{2} A R$ (ELENKOV et al., 2000; KOHM; SANDERS, 2000). Alguns modelos animais mostraram que a noradrenalina inibe a proliferação de células $\mathrm{T}$ pela estimulação de $\beta_{2} \mathrm{AR}$, o que pode explicado pelo aumento dos níveis intracelulares de AMPcíclico que inibiria a produção de IL-12, um importante estímulo proliferativo (ELENKOV et al., 2000; KOHM; SANDERS, 2001). 
O isolamento social representa uma forma de estresse psicológico que produz ativação simpática. Gavrilovic et al. (2010) investigaram as alterações na expressão gênica e nos níveis protéicos da bio-síntese das enzimas catecolaminérgicas tirosina hidroxilase $(\mathrm{TH})$, dopaminabeta-hidroxilase (DBH) e metil-fenilanina transferase (PNMT) na medula da adrenal de roedores mantidos em grupos controle ou cronicamente estressados (por isolamento social de 12 semanas). O autor mostrou que os animais cronicamente estressados apresentavam uma expressão significantemente menor das enzimas de síntese catecolaminérgica, concluindo que o estresse psicológico influenciaria a expressão gênica e os níveis destas enzimas; sugeriu ainda, que teria ocorrido uma adaptação na síntese de catecolaminas induzidas nos animais pelo estresse crônico (GAVRILOVIC; SPASOJEVIC; DRONJAK, 2010). Outro trabalho também utilizando o mesmo modelo experimental (isolamento social) avaliou a ansiedade, assim como a ativação do SNS e a resistência dos esplenócitos aos glicocorticóides após um estresse social (HANKE et al., 2012). Destaque-se que os animais apresentaram um aumento de catecolaminas plasmáticas, aumento dos níveis de ansiedade, aumento de IL-6, TNF- e MCP-1 plasmáticos (que foram revertidos após um pré-tratamento com propanolol, um antagonista $\beta$ adrenérgico); nenhuma interação com os glicocorticóides foi entrtanto confirmando-se a ausência de participação do eixo HPA monstrando que as alterações observadas eram conseqüência da ativação do SNS (HANKE et al., 2012).

De modo geral, a maioria dos trabalhos indica que as catecolaminas promovam uma diminuição de citocinas Th1 e um aumento de citocinas Th2. Assim é possível sugerir que os efeitos da condição experimental sobre o burst oxidativo induzido por PMA e por S. aureus dos neutrófilos, sejam consequência de alterações nos padrões de citocinas produzidas e/ou liberadas pelas células, na presença de um cenário em que predomina uma ativação catecolaminérgica. De fato, é de amplo conhecimento que as citocinas desempenham um papel relevante na produção de espécies reativas de oxigênio (LEHN et al., 1989). As interações entre sistema nervoso e sistema imune são extensas e podem incluir vários hormônios; podemos assim sugerir que as alterações presentes neste trabalho sejam decorrentes da ativação do SNS.

Sabemos que o animal que convive com o doente apresenta alterações no burst oxidativo e na fagocitose de neutrófilos (ALVES et al., 2006). Após um estímulo biológico como, por exemplo, presença de bactérias, os neutrófilos produzem espécies reativas de oxigênio, como o peróxido de hidrogênio, o ânion superóxido e o radical hidroxila, num processo intracelular rico em consumo de oxigênio e, por isso, conhecido como burst oxidativo (ELSBACH; WEISS, 1983). No presente trabalho, tanto o burst oxidativo induzido 
por PMA como por Stapyilococcus aureus foram menores nos animais machos companheiros dos doentes (CAD) corroborando com os dados dos estudos feitos anteriormente pelo nosso grupo em fêmeas (ALVES et al., 2006).

De maneira geral, os tumores produzem compostos orgânicos voláteis, que são liberados para a atmosfera através da urina, suor e respiração (PHILLIPS et al., 1999; PHILLIPS et al., 2003; MATSUMURA et al., 2010). Assim, foi sugerido que os odores liberados pelos animais doentes portadores de um tumor ascítico de Ehrlich fossem os responsáveis pelas mudanças neuroimunes relatadas. Para estudar este fato, Alves e PalermoNeto $(2013)^{1}$ fizeram outro experimento seguindo o mesmo modelo experimental, porém mantendo os animais em trios,em que dois possuíam o tumor ascítico de Ehrlich e um animal saudável. Observaram uma admirável e maior redução tanto no burst oxidativo basal como o burst oxidativo induzido por PMA ou por Staphylococcus aureus, assim como da porcentagem de fagocitose de neutrófilos sanguineos em animais mantido em trios (dois componentes saudáveis e um doente) do que em duplas (um doente e um saudável). Por outro lado, nenhuma alteração foi encontrada no burst espontâneo (DCFH), indicando este achado que o efeito da situação experimental só se manifeste na vigência de uma estimulação das células imunes. Outro fato interessante do nosso trabalho, foi a ausência de alteração em relação a porcentagem e a intensidade de fagocitose nos machos, dados diferentes dos relatados anteriormente por Alves et al. (2006) em fêmeas (ALVES et al., 2006).

A fagocitose é um fenômeno complexoque se inicia pela ligação da partícula a ser fagocitada a receptores específicos presentes na superfície da célula imune. Existem vários receptores fagocíticos: dentre eles citamos o $\mathrm{Fc} \gamma \mathrm{R}$ (receptores para a porção $\mathrm{Fc}$ da IgG ligada a partícula), receptores CR (receptores para alguns componentes do sistema complemento depositado em algumas superícies das partículas), receptores de lectina e receptores scavenger. A internalização da partícula é resultado de muitas vias de sinalização que, em seu conjunto, coordenam o rearranjo do citoesqueleto da célula imune, portanto o englobamento desta. A fagocitose é um processo ativo induzido entre outros por produtos bacterianos ou tumorais, com um papel importante das citocinas nesse processo (FIDLER, 1985; KELLER et al., 1990). Assim por exemplo, mostrou-se que a fagocitose pode ser modulada in vitro e in vivo por citocinas, para diferentes estados de ativação funcional (NATHAN; KARNOVSKY; DAVID, 1971; LEHN et al., 1989).

\footnotetext{
${ }^{1}$ PALERMO-NETO; J.; ALVES, G. J. Neuroimmune interactions and psychologycal stress induced by cohabitation with a sick partner: A review. Bain Research, 2013. Enviado.
} 
Sabe-se que, o dimorfismo sexual leva a diferenças tanto na imunidade inata quanto adaptativa (KLEIN; JEDLICKA; PEKOSZ, 2010; RUBTSOV et al., 2010). Na verdade mostrou-se que as fêmeas possuem uma menor carga de infecções bacterianas, virais e parasitárias, principalmente durante seus anos reprodutivos. Inversamente, mulheres têm uma prevalência mais elevada de uma série de doenças auto-imunes, incluindo-se aqui a síndrome de Sjogren, o lupos eritematoso sistêmico, a escleroderma, a artrite reumatóide e a esclerose múltipla. Estas observações sugerem que os hormônios sexuais possam ter um papel importante neste diferencial. A diferença fundamental no sistema imune entre machos e fêmeas tem sido atribuída não apenas às diferenças de hormônios sexuais, como também à contribuição genética do cromossomo X e aos fatores ambientais (FISH, 2008; GHAZEERI; ABDULLAH; ABBAS, 2011).

Os receptores estrogênicos estão presentes em níveis elevados no trato reprodutivo das fêmeas, mas também, podem ser encontrados em linfócitos B e $\mathrm{T}$, células dendríticas, macrófagos, neutrófilos, células NK, células do estroma tímico, da medula óssea e células endoteliais (BOUMAN; HEINEMAN; FAAS, 2005; ACKERMAN, 2006; HELDRING et al., 2007). Os estrógenos influenciam a maturação de linfócitos T e B (ACKERMAN, 2006; HILL et al., 2011), diminuem a linfopoiese de célula B via IL-7 pelas células do estroma da medula óssea (HILL et al., 2011), promovem o fenótipo de CD4+CD8+ (SELI et al., 2002; SHAMES, 2002; TANRIVERDI et al., 2003), estimulam as células B e aumentam a produção de anticorpos, promovem uma resposta Th2 e resultam num aumento dos níveis de IL-4, IL-5 e IL-10. Os receptores de andrógeno são encontrados em linfócitos B e T, melhoram a resposta Th1, especificamente conduzindo o aumento da produção de IL-2 e aumentam a ativação das células T CD8+, responsáveis então, pela tolerância e homeostase de células B (BOUMAN; HEINEMAN; FAAS, 2005; ACKERMAN, 2006; ZANDMAN-GODDARD; PEEVA; SHOENFELD, 2007). Portanto, fêmeas apresentam uma preponderância para uma resposta imune Th2 e ativação de células $B$, enquanto machos, geram predominantemente Th1 e linfócitos CD4+CD8+ (GHAZEERI; ABDULLAH; ABBAS, 2011).

Em relação à população de leucócitos residentes, por exemplo, na cavidade pleural e peritoneal, as fêmeas (camundongos e ratos) apresentam um maior número de células residentes, sendo diferente tanto numérica quanto funcionalmente em relação aos machos (PENNELL; GALliGAN; FISH, 2012). Embora a contagem total de linfócitos seja semelhante entre homens e mulheres (GILTAY et al., 2000; BOUMAN et al., 2004), a porcentagem de linfócitos $\mathrm{T}$ em homens é menor em comparação com as mulheres (BOUMAN et al., 2004). A diminuição da contagem de linfócitos $\mathrm{T}$ em machos pode ser 
devida ao aumento dos níves de testosterona, uma vez que este hormônio pode aumentar a apoptose de células T (MCMURRAY et al., 2001). Existem relatos mostrando que os linfócitos $\mathrm{T}$ sejam insensíveis à testosterona, devido à ausência de receptores androgênios (COHEN, J. H. et al., 1983), estudos recentes têm demonstrado um receptor de testosterona na membrana linfócitos, diferente do receptor intracelular clássico deste hormônio (BENTEN et al., 1999). Já, os Linfócitos B expressam apenas receptores de androgênio intracelular (BENTEN; STEPHAN; WUNDERLICH, 2002). Na literatura foi encontrado apenas um estudo relatando a existência de expressão de receptor de andrógeno em macrófagos murinos (BEBO et al., 1999) e não há relatos sobre a presença de receptores androgênicos em neutrófilos humanos, monócitos ou células NK (BOUMAN; HEINEMAN; FAAS, 2005).

Os granulócitos constituem aproximadamente $65 \%$ de toda população de leucócitos do sangue e pode ser agrupados em basófilos, eosinófilos, e os neutrófilos. Uma vez que os neutrófilos constituem 90-95\% dos granulócitos, eles são bem investigados em relação aos efeitos dos hormônios sexuais. Os neutrófilos são as primeiras células recrutadas a partir da corrente sanguínea para os locais de infecção; são células diferenciadas incapazes de divisão celular, sintetizambaixos níveis de RNA e proteína e são essenciais para a resposta inflamatória aguda e para a resolução de infecção microbiana. A Progesterona e o estrogênio já foram relacionados ao aumento do número de granulócitos. Alguns autores demonstraram que a progesterona aumenta a atividade quimiotáctica de neutrófilos, enquanto que estrógenos diminuem esta atividade (MIYAGI et al., 1992). Os efeitos da progesterona e do estrógeno sobre a produção de radicais livres pelos neutrófilos têm sido também investigados por vários grupos. A incubação in vitro de neutrófilos com estrógeno ou progesterona mostrou resultados diversos como por exemplo, o aumento da produção de radicais livres (MOLLOY et al., 2003), redução (BEKESI et al., 2000) e até mesmo nenhum efeito (CASSIDY, 2003). Apesar de serem necessários outros estudos a respeito, sugere-se que o dimorfismo sexual afete o número e a função de neutrófilos, sendo que o exato mecanismo desta ação ainda é desconhecido. De qualquer forma, estrógenos tendem a ter um efeito antiinflamatório em neutrófilos enquanto que a progesterona apresente um efeito pró-inflamatório. Portanto, os hormônios sexuais podem afetar a resposta imune inata modulando o número e a função dos neutrófilos (BOUMAN; HEINEMAN; FAAS, 2005). Esta pode ter sido a razão das diferenças em relação aos trabalhos de Alves et al. (2006) e agora aponte das em machos no tocante aos efeitos da convivência com um doente sobre a fagocitose.

De fato, os efeitos dos hormônios sexuais sobre o sistema imune (imunossupressão ou imunoestimulação) podem variar, mesmo na presença de um mesmo hormônio. Por exemplo, 
o estrógeno pode aumentar os níveis de $\operatorname{IgA}$ no útero, mas diminuem os níveis de $\operatorname{Ig} \mathrm{A}$ na vagina (SULLIVAN; HANN, 1989). Algumas destas razões para essa variabilidade têm sido revistos em detalhe em outros trabalhos (STEINBERG et al., 1979; ANSAR AHMED; PENHALE; TALAL, 1985), que incluem as concentrações dos hormônios envolvidos, a idade dos animais, a imunocompetência do hospedeiro, os stresses envolvidos e o seu metabolismo, resultando em alteração da atividade biológica e diferentes respostas a vários antígenos. O contato inicial dos hormônios sexuais com o tipo de células alvo, a variabilidade de mensageiros secundários e eventos de ativação de genes são outras considerações importantes.

Ressalta-se, neste momento, que o burst oxidativo e a fagocitose são eventos diferentes, modulados de forma similar, porém não idêntica por diferentes citocinas, e que não guardam necessariamente relações de causalidade. Em seu conjunto, os presentes dados de neutrófilos sugerem uma diminuição da resistência do animal em uma situação de convivência com um companheiro doente Neste sentido, é inegável que os efeitos dos hormônios sexuais sobre a modulação do sistema imunológicosão inequívocos. Os avanços crescentes em imunologia celular, endocrinologia e biologia molecular, proporcionam uma melhor compreensão das interações de hormônios com o sistema imunológico, no modo pelo qual os hormônios ativam genes específicos, e da maneira como os hormônios sexuais influenciam a comunicação intracelular (AHMED; TALAL, 1990). Portanto, os efeitos dos hormônios sexuais sobre o sistema imunológico não podem ser generalizados, mas devem ser avaliados de forma independente. Desta forma, alguns estudos mais verticalizados conduzidos nestas direções poderão explicar as discrepâncias agora apontadas para os efeitos da convivência com doentes na fagocitose de neutrófilos tomados de machos e de fêmeas. Assim, mais estudos são necessários para elucidar os resultados agora obtidos, uma vez que os hormônios sexuais podem agir de formas diferentes em diversas situações como citado acima. É até mesmo possível supor de o estresse da convivência afeta de forma diferencial os níveis circulantes de hormônios sexuais em machos e fêmeas ou a relação hipotálamohipófise-gonadal.

Alterações da função imune são consideradas mais relevantes quando resultam em alterações patológicas, microbiológicas e/ou clínicas significantes. Células do tumor de Ehrlich eliciam uma forte resposta imune no hospedeiro (PESSINA; BRAMBILLA; MOCARELLI, 1980; SEGURA; BARBERO; MARQUEZ, 1997) um fato que, junto com outras propriedades, tem feito deste tumor um interessante modelo para a análise dos efeitos de fármacos e/ou de eventos comportamentais sobre o crescimento tumoral. Uma resposta 
imune efetiva contra tumores requer a cooperação entre macrófagos,linfócitos T e B e células NK. Assim, a supressão de um ou mais destes componentes pode comprometer a imunocompetência alterando o crescimento tumoral. Sabe-se que os mecanismos para a diminuição da resistência à invasão tumoral em um hospedeiro podem incluir a diminuição dos níveis dos fatores anti-angiogênicos (ZETTER, 1998), liberação local e sistêmica dos fatores de crescimento (HOFER et al., 1999) e a supressão das células imunes (SIETSES et al., 1999; MELAMED et al., 2005). A adrenalina e a noradrenalina, liberadas devida uma situação de estresse, têm participação na progressão de tumores. Em um modelo de carcinoma ovariano, o estresse foi mimetizado através de uso de um agonista de receptores $\beta$, que causou um aumento na progressão deste tumor, este efeito foi antagonizado por um $\beta$ bloqueador;a ativação direta dos receptores $\beta$-adrenérgicos foi associada com um aumento significativo na vascularização do tumor; desta forma, um aumento na angiogênese parece ter sido o principal mecanismo dos efeitos dos promotores de crescimento da adrenalina e noradrenalina (TILAN; KITLINSKA, 2010).

Observamos que a convivência com animais doentes diminuiu a resistência dos camundongos ao desenvolvimento do tumor ascítico de Ehrlich, corroborando com os dados observados anteriormente por Morgulis et al. (2004) e Alves et al.(2007) em camundongos fêmeas (MORGULIS et al., 2004; ALVES; VISMARI; PALERMO-NETO, 2007). Especificamente, numero total de células tumorais e a concentração destas células no líquido ascítico estão aumentadas. Porém, o volume deste líquido não foi modificado o que sugere que a situação experimental não alterou a permeabilidade vascular dos animais do grupo experimental $(\mathrm{CAD})$ e que tenha mesmo ocorrido queda de resistência orgânica doa animais, isto é, progressão do número de células tumorais em animais do grupo CAD.

Sakai (2006), analisando as ações do diazepam, sugeriu uma relação entre os efeitos do fármaco no crescimento tumoral e aqueles por ele induzidos nas atividades de macrófagos (SAKAI et al., 2006a). Palermo-Neto et al. (2003) empregaram o mesmo raciocínio para explicar os efeitos de um estresse inescapável e de outro de natureza psicológica sobre o crescimento deste tumor em camundongos (PALERMO-NETO; DE OLIVEIRA MASSOCO; ROBESPIERRE DE SOUZA, 2003). Sá-Rocha et al. (2006), em um estudo envolvendo um estresse psicológico, como a relação hierarquia dominante e submisso (o que representa também um estresse crônico), mostraram que os animais submissos apresentaram um aumento de metástase do tumor B16F10 nos pulmões e diminuição da citotoxicidade das células NK mensuradas in vitro do sangue periférico e do baço (SA-ROCHA; SA-ROCHA; PALERMO-NETO, 2006). O isolamento social de camundongos também é um motivo de 
estresse crônico e consequente aumento da atividade do SNS modulando o sistema neuroendócrino e imune (BARTOLOMUCCI, 2007). Um estudo feito por Palermo-Neto et al. (2008), mostrou que o estresse por restrição social muda a resposta imune e endócrina, aumentando os níveis de ansiedade e diminuindo a resistência orgânica ao crescimento do tumor ascítico de Ehlich nestes animais (PALERMO-NETO et al., 2008).

Podemos concluir então, que a convivência com um animal doente represente um estresse psicológico prolongado também para machos e, via ativação do SNS altera a atividade de células imunes inatas e a resistência orgânica ao crescimento tumoral.

A interface neuro-imuno-endócrina é mediada por citocinas que são substâncias sintetizadas e secretadas por diferentes tipos de células e que constituem um componente importante na comunicação entre o sistema imune e os tecidos periféricos, auxiliando as respostas imune inata e adquirida (DINARELLO; MIER, 1987; PAUL; SEDER, 1994; ABBAS; MURPHY; SHER, 1996). Após um desafio microbiano, por exemplo, um padrão particular de citocinas induzirá fagócitos residentes a destruir e erradicar patógenos do local da infecção. Por outro lado, a resposta imune adaptativa irá atuar recrutando células $\mathrm{T}$ helper (Th) direcionando-as para uma resposta imune celular (Th1) ou humoral (Th2) (ROMAGNANI, 1997; GLIMCHER; MURPHY, 2000). Células Th1 são associadas com a síntese e secreção de IL-2 e IFN- $\gamma$ (citocinas pró-inflamatórias), já as células Th2 são associadas com secreção de IL-4, IL-5, IL-9, IL-10 e IL-13 (citocinas antiinflamatórias). O microambiente gerado pela presença de um padrão característico de citocinas pode influenciar a geração e/ou diferenciação de subtipos distintos de células dendríticas, as quais, mais tarde, iniciarão uma resposta imune específica contra o patógeno (KOVALOVSKY et al., 2000; LIBERMAN; REFOJO; ARZT, 2003). De fato, mostrou-se que várias citocinas entre elas, o TNF- $\alpha$, influenciam a expressão e a sinalização via subtipos de receptores adrenérgicos em células imunes; desta forma, especula-se que o microambiente de citocinas necessário para dirigir uma diferenciação de células em um perfil Th1 ou Th2, influenciaria também os níveis de expressão de receptores adrenérgicos em células do sistema imune (HADRI et al., 1997).

Pesquisamos neste trabalhoosníveis de citocinas no baço com intuito de avaliar como o estresse de conviver com um animal doente afetaria a produção destas pelas células do sistema imune. Na cultura de esplenócitos estimulada com LPS em 24 horas de estímulo observamos um aumento das concentrações de TNF- $\alpha$, IFN- $\gamma$ e IL-6 e, após 48 horas de estímulo, observamos um aumento persistente de TNF- $\alpha$ e IL-6 comparado aos animais controles (CAS). Após 48 horas os níveis de IFN- $\gamma$ e IL-10 não foram estatisticamente significantes em relação ao CAS. Lembrando que não foram detectadas as citocinas IL-12 em 
nenhum dos períodos analisados e IL-10 após 24 horas de estímulo. Portanto, observamos um aumento de produção de citocinas inflamatórias nos animais CAD aoós estimulação com LPS.

Durante uma infecção ou injúria o TNF é um dos primeiros e mais potentes mediadores da inflamação. Ele é sintetizado principalmente por monócitos/macrófagos e células T e sua meia vida na circulação é de aproximadamente 20 minutos. O TNF tem um importante papel no direcionamento da resposta inflamatória e na ativação de mediadores pertencentes à cascata de citocinas, sendo também, um potente indutor de citocinas próinflamatórias. Com relação a IL-6, sabe-se ser sua síntese induzida por TNF e IL-1 a partir de diversos tipos celulares incluindo linfócitos e monócitos. Os níveis circulantes destas citocinas podem ser detectados 7 a 10 dias após uma injúria e, como amplamente salientado, elas podem produzir vários efeitos incluindo a ativação neutrofílica, indução de resposta hepática de fase aguda e ativação da coagulação (JOHNSTON; WEBSTER, 2009). Em especial, a IL-6 a) pode controlar a proliferação de células T e a apoptose induzida por IL-2, b) ativar a produção de citocinas $\mathrm{Th} 2, \mathrm{c})$ regular o balanço entre células $\mathrm{T}$ regulatórias e células Th17 juntamente com o TGF- $\beta$, d) inibir a diferenciação de células T regulatórias e e) manter a secreção de IL-17 nos tecidos inflamados (NEURATH; FINOTTO, 2011). Uma das citocinas que desempenha um papel proeminente na resposta imune específica é o IFN- $\gamma$. Esta citocina promove a ativação de macrófagos aumentando suas propriedades antimicrobianas e levando a uma maior expressão das moléculas do complexo de histocompatibilidade (MHC), o que induz a apresentação de antígenos às células T (PAMER, 2004; ZENEWICZ; SHEN, 2007), esta citocina é capaz de inibir a atividade de células Th2 e atua controlando principalmente a imunidade celular (BOUMAN; HEINEMAN; FAAS, 2005).

Em relação, as citocinas esplênicas, esperar-se-ia verificar uma diminuição das citocinas pró-inflamatórias (TNF-alfa, IF-gama e IL-6) e aumento das antiinflamatórias (IL10), já que o estresse crônico suprimi a resposta imune celular do tipo Th1 (ELENKOV; CHROUSOS, 1999). Surpreendentemente, após incubação dos esplenócitos dos animais dos grupos CAD e CAS por 24h e 48h com LPS verificou-se aumento da produção das citocinas pró-inflamatórias nos animais do grupo CAD, acompanhada de aumento, em menor intensidade de IL-10 no mesmo grupo. Assim, é possível supor que os efeitos induzidos pelo estresse da convivência com doente sejam diferentes daquele produzidos por outros estresses psicológicos crônicos. Pode ser que o estímulo produzido pelo odor proveniente dos animais “doentes" mobilize mais do que uma simples ativação do SNS. 
De qualquer forma, permanece o fato de que os estressados responderam mais ao estímulo (LPS). Foi verificado que embora aumentadas, as citocinas pró-inflamatórias diminuíam com o decorrer do tempo. Existem relatos na literatura de que o estresse agudo, após ativação do simpático, desencadeie uma resposta estimulante da resposta imune celular do tipo Th1. Após algumas dezenas de minutos, esta resposta Th1 é inibida e sendo substituída por outra, com prejuízo do balanço Th1/Th2 e consequente ativação da resposta imune Th2 (ELENKOV; CHROUSOS, 1999; 2002; GOMEZ et al., 2013). Essas alterações podem contribuir para a desregulação das funções imunológicas específicas envolvendo células T e B, e podem diminuir a capacidade de lidar com agentes intracelulares após situações de estresse. No presente estudo, os animais já haviam sido estressados previamente pela convivência com o doente; nossos resultados sugerem que este estresse nos machos não tenha sido suficiente para prejudicar a resposta imune celular dos esplenócitos do baço frente à estimulação com LPS. Haveria aqui, também dimorfismo sexual?

Outro ponto a ser observado refere-se ao fato de que não quantificamos neste trabalho os linfócitos T e B no baço e, por isso, não sabemos se o aumento de citocinas observado se deve a um aumento de linfócitos T neste órgão ou a uma maior funcionalidade destas células.

Diferentes substâncias têm sido estudadas com o intuito de compreender a neurofisiologia que envolve a ansiedade e o estresse. Nesse sentido, o estudo de aminas biogênicas, como a noradrenalina, a dopamina e a serotonina em diferentes regiões cerebrais são frequentemente aplicadas para esta avaliação.

Com relação aos neurônios que sintetizam noradrenalina no SNC, estes estão situados nas regiões bulbar e pontinea, sendo que o grupo mais importante situa-se no locus ceruleus. As células do locus ceruleus, quando ativadas por estresses produzem uma reação comportamental característica de medo. De fato, já foi relatado que situações indutoras de estresse ativam sistemas noradrenérgicos centrais e produzem aumento do turnover de noradrenalina medido através da análise dos níveis deste neurotransmissor e de seu principal metabólito o MHPG no SNC (GLAVIN et al., 1983; CHARNEY; HENINGER, 1985). No presente trabalho, o metabólito da noradrenalina analisado foi o VMA, uma vez que o aparelho de HPLC não detectou os níveis de MHPG. Em particular, áreas da região límbica como o hipotálamo, a amigdala e o hipocampo apresentam aumentos rápidos e de significativa magnitude no turnover de noradrenalina em resposta a estressores como, por exemplo, contenção e choque nas patas e comunicação emocional (IIMORI et al., 1982). Neste presente estudo, os níveis de VMA não foram detectados pelo aparelho de HPLC no hipotálamo não permitindo assim, a análise de turnover nesta região. Neste sentido, cabe 
mencionar que as alterações neuroquímicas nos machos não foram tão marcantes e consistentes quando comparadas àquelas vistas em fêmeas por Alves (2006).

Em animais de laboratório, mostrou-se que o estresse aumenta a atividade de células do locus ceruleus (SIMSON; WEISS, 1988; PAVCOVICH et al., 1990), de acordo com Abercrombie, Keller e Zigmond (1988) o incremento do turnover de noradrenalina induzido pelo estresse é consequência de um aumento na atividade da enzima tirosina hidroxilase (ABERCROMBIE; KELLER; ZIGMOND, 1988). Neste contexto, a magnitude da depleção dos níveis de noradrenalina após um estímulo estressor já foi correlacionada inversamente com as alterações por ele produzidas em animais de laboratório; isto é, quanto menores os níveis de noradrenalina maiores foram às respostas ao estímulo estressor (GLAVIN et al., 1983).

No presente trabalho, o turnover de noradrenalina foi observado no córtex frontal tendo-se observado aumento do turnover. Portanto, os níveis de VMA aumentados e aumento de turnover de noradrenalina sugerem a ação do estresse pela convivência nesta região do SNC. Foi ainda possível observar uma diminuição nos níveis de noradrenalina no bulbo, mesmo não havendo uma alteração em seu turnover e metabólitos, como citado acima por Glavin (1983), sugere-se que este neurotransmissor tenha sido reduzido, talvez por consumo maior em resposta ao estresse. Cabe a nós sugerir que talvez o período de análise não tenha permitido a detecção de efeitos sobre os metabólitos e que, realmente, tenha ocorrido uma ação do estresse nesta região. De fato, ela é de extrema importância para este estudo, uma vez que como comprovado por Alves $(2010,2012)$ o odor do tumor do animal doente é o responsável por causar um estresse crônico no companheiro com consequente ativação do SNAS (ALVES et al., 2010; ALVES; RIBEIRO; PALERMO-NETO, 2012).

Também tem sido proposto um papel relevante para a dopamina na mediação da resposta orgânica aos estressores (ROTH et al., 1988; LE MOAL; SIMON, 1991; CHARMANDARI; TSIGOS; CHROUSOS, 2005). Dois sistemas dopaminérgicos, o mesolímbico e o mesocortical, são aqueles ativados preferencialmente na vigência de estressores moderados (CARLSON et al., 1987) enquanto que, uma ativação mais global de toda atividade dopaminérgica central ocorre apenas quando da presença de uma estimulação mais severa (ABERCROMBIE et al., 1989). De modo geral, relata-se que um estresse mais agudo produza um aumento do turnover de dopamina e uma redução de seus níveis no SNC. Alguns autores mostraram, no entanto, que os efeitos do estresse sobre a atividade dopaminérgica central dependam não apenas da intensidade do estresse, como comentado acima, como também da duração da situação indutora do estresse (LE MOAL; SIMON, 
1991). Assim, por exemplo, a exposição de um organismo a um estresse prolongado produziu efeitos sobre o sistema dopaminérgico que foram diferentes daqueles relatados após um estresse agudo; de fato, mostrou-se que os níveis de dopamina podem se encontrar até mesmo aumentados após uma situação de estresse crônico (ROTH; MEFFORD; BARCHAS, 1982). Baseados nesses últimos resultados tem sido hipotetizado que o estresse crônico produza um aumento compensatório na biossíntese de dopamina, de tal forma a manter a homeostase dopaminérgica na vigência do prolongamento da situação. Em especial, mostrou-se que a ativação de neurônios dopaminérgicos do córtex frontal que é parte do sistema dopaminérgico mesocortical- está associada a uma tentativa orgânica de inibir a atividade dos circuitos neurais ligados ao estresse (DIORIO; VIAU; MEANEY, 1993).

Em nosso trabalho, observamos apenas uma diminuição do metabótito HVA no hipotálamo e no bulbo, o que não condiz com os dados de literatura em relação ao sistema dopaminérgico e os estresses citados acima. Isso pode sugerir que este sistema não tenha sido influenciado por este tipo de estressor agora usado nos machos, de maneira semelhante ao apontado na literatura para estes estresses. Será então, que o tipo de estressor deste estudo é tão marcante para os machos quanto para fêmeas? De fato estudos mostraram aumento nos níveis de dopamina após a convivência com doentes (PALERMO-NETO; ALVES, 2013)². Destaca-se, no entanto, que por não termos mensurado estas monoaminas em outros momentos, não podemos ter certeza de que não tenha ocorrido alteração nesta via dopaminérgica em algum momento durante a convivência com o doente. De fato, o estresse do presente trabalho não deve ser compreendido apenas como um estímulo ou como uma resposta, mas como um processo.

O estresse ativa o locus ceruleuse a ativação deste núcleo é acompanhada por um aumento na atividade do SNAS e também por aumento da atividade noradrenérgica no SNC. Um aumento da atividade no locus ceruleusjá foi também apontado como decorrência do estresse que, também interfere com a atividade de sistemas dopaminérgico (ROTH et al., 1988; LE MOAL; SIMON, 1991; CHARMANDARI; TSIGOS; CHROUSOS, 2005). Neste contexto, mostrou-se que a ativação de fibras noradrenérgicas neste local esta relacionada a um aumento de atividade locomotora em animais de laboratório (LE MOAL; SIMON, 1991) e, também que os sistemas dopaminérgicos têm intima relação com a função motora e, portanto, com a locomoção (DIORIO; VIAU; MEANEY, 1993). Este dado de literatura não corrobora com nos agora obtidos no em campo aberto (discutidos mais adiante), em que não

\footnotetext{
${ }^{2}$ PALERMO-NETO; J.; ALVES, G. J. Neuroimmune interactions and psychologycal stress induced by cohabitation with a sick partner: A review. Brain Research, 2013. Enviado
} 
foram observadas diferenças estatísticas significantes entre os grupos quanto à locomoção. Podemos, dessa forma, correlacionar com os dados comportamentais a ausência de alterações na dopamina do que com a noradrenalina. Haveria alguma contribuição dos sistemas serotoninérgicos para estes fatos?

Sabe-se que um dos moduladores do comportamento em situações de aproximação/excitação é o sistema serotoninérgico. De fato, há muito tempo tem se relacionado o aumento da atividade serotoninérgica no SNC com diminuição da impulsividade (GRAEFF, 2003). Existem diversas contradições nos estudos que analisam o envolvimento do sistema serotoninérgico com os níveis de ansiedade. Estudos embasados em teste de conflito ou punição mostraram inibição da síntese de serotonina. Como os testes de conflito são encarados como modelo de ansiedade, estes resultados indicam que a serotonina aumentaria os níveis de ansiedade. Entretanto, em outros modelos animais de ansiedade, por exemplo, naquele em que se faz estimulação elétrica das patas, a própria serotonina e outros agonistas de receptores serotoninérgicos atenuaram a fuga induzida por esta estimulação (DEAKIN; GRAEFF, 1991). De forma geral, a serotonina diminui a ansiedade, apesar de sua ação ainda ser bem controversa. Nossos resultados mostraram um aumento dos níveis de serotonina e de seu metabólito 5HIAA em córtex frontal em machos, diferenciando-os dos resultados obtidos por Palermo-Neto e Alves $(2013)^{3}$ em fêmeas. Estes dados pareçam explicar o porquê de os machos apresentarem menor alteração de locomoção no campo aberto quando comparado às fêmeas.

Mais especificamente, sobre o comportamento dos animais no campo aberto os dados obtidos no presente trabalho não indicaram diferenças entre os grupos CAS e CAD, resultados diferentes dos observados pelo nosso grupo em fêmeas (MORGULIS et al., 2004; ALVES et al., 2006).

A diferença entre os sexos esta bem estabelecida na psiquiatria, em que a maior incidência de transtornos de humor e ansiedade estão presentes em fêmeas. Estes distúrbios apontam o estresse como um potente contribuidor etiológico e ferramenta chave para a manifestação dos sintomas, sugerindo que diferenças entre sexos situam-se na intersecção entre estresse e alterações comportamentais. As fêmeas apresentam maior magnitude de ativação do locus ceruleus comparado aos machos sob idênticos níveis de estresse; a resposta aos estressores pode ser qualitativamente distinta entre machos e fêmeas como resultado do

PALERMO-NETO; J.; ALVES, G. J. Neuroimmune interactions and psychologycal stress induced by cohabitation with a sick partner: A review. Brain Research, 2013. Enviado 
envolvimento de diferentes células e/ou vias de sinalização. Há uma diferença na estrutura neuronal do locus ceruleus entre machos e fêmeas, devido a estas células serem mais complexas e possuírem dendritos mais longos em fêmeas; por isso elas estão melhor programada para receber e processar informações particularmente relacionadas com emoçõestransmitidas pelo sistema límbico. Esta diferença entre os sexos permite evidenciar um maior nível de excitação afetiva e flexibilidade comportamental nas fêmeas, o que pode ser uma adaptação evolutiva como parte da função materna (VALENTINO et al., 2012). Então de fato, pode-se afirmar que machos e fêmeas respondem deforma diferente a uma situação estressora o que explicaria grande parte das diferenças agora relatadas entre machos e fêmeas. Porém, a demonstração de uma diferença no nível dos mecanismos, ainda não esclarece uma questão fundamental suscitada quando se comparam os dados do presente trabalho com outros de nosso grupo. Por que alguns resultados foram diferentes?

Duas hipóteses, não necessariamente concorrentes, podem ser responsáveis pelas discrepâncias entre machos e fêmeas, são elas:

- Machos e fêmeas de camundongos apresentaram graus de investimentos muito diferentes no que se refere ao comportamento reprodutivo. Enquanto os machos contribuem apenas com a cópula e o sêmen "inoculado" em diferentes fêmeas, as fêmeas apresentam um investimento bastante alto, uma vez que têm que gestar e depois cuidar e amamentar a prole. Portanto a possibilidade de adquirir uma doença representaria em curto prazo, uma ameaça grave à finalidade última da vida que seria a de deixar o maior número de descendentes viáveis.

De fato, a própria literatura de neuroimunomodulação traz dados que corroboram com essa hipótese. Avitsur et al. (1997) demonstraram, em ratos, que administração da mesma dose de LPS ou IL-1 $\beta$ suprime o comportamento sexual em fêmeas, porém não em machos, embora, reduzinda a atividade locomotora nos dois gêneros (AVITSUR; POLLAK; YIRMIYA, 1997). Os autores mostraram, ainda, que uma fêmea tratada com LPS apresentase menos atraente para os machos, fato que não ocorre com os machos tratados com a mesma dose; argumentam, também, que a infecção represente um alto risco para a fêmea que precisagestar, parir e amamentar a prole. No caso do macho a mesma infecção não constitui uma ameaça imediata à reprodução (AVITSUR; YIRMIYA, 1999). Essa explicação corrobora com a hipótese de investimentos orgânicos diferentes entre os gêneros. Fêmeas investem diretamente na reprodução, muito mais que os machos, daí o fato de elas serem mais 
suscetíveis aos efeitos da doença e possivelmente, mais suscetíveis aos efeitos potencialmente estressores da convivência com uma co-específica doente.

- A outra hipótese refere-se à própria forma como se dá a estruturação social de uma colônia de camundongos. Em condições selvagens ou semi-naturalísticas, via de regra, só existe um macho adulto numa colônia de camundongos. Trata-se do dominante que expulsa os demais machos e detém o controle dos recursos e do território, o que possibilita que ele atraia fêmeas férteis para o seu território e forme um harém. Filhotes machos provenientes do interior da colônia, ao se tornarem adultos, ou sobrepujam o dominante e assumem o controle da colônia ou, mais frequentemente, são expulsos do território. No caso das fêmeas o comportamento social é bastante diferente. As fêmeas pertencentes a um mesmo território ou harém, dividem o ninho e frequentemente os cuidados com as proles que são do mesmo macho.

Com isso, fica evidente que as fêmeas de camundongo apresentam comportamento cooperativo e os machos não (diferentemente dos ratos, onde os machos dominantes e subordinados cooperam na proteção do território). Ora, seria então natural de se esperar que para uma fêmea, a existência de uma companheira doente seja um maior fator gerador de estresse, pois além do risco de contágio, existiria a potencial perda de um colaborador. No caso dos machos, existiria apenas um potencial risco de contágio.

Cohn et al.(2012) mostraram que camundongos machos subordinados passam a atacar um "companheiro" dominante quando este último recebe tratamento com LPS durante três dias consecutivos e passa a exibir comportamento doentio. Os autores argumentam que isso indica que ao se deparar com um dominante doente, o subordinado visualizaria a oportunidade de agredí-lo para se tornar o dominante e assumir o controle da colônia (COHN; KINOSHITA; PALERMO-NETO, 2012).

Portanto pode-se discutir aqui, que ao se comparar o caso dos machos com o das fêmeas, temos que para ambos, a convivência com um co-específico de mesmo gênero, portador do tumor ascítico de Erlich representaria um potencial agente estressor, porém de naturezas bastante diversas. O que pode ser um estímulo para afastamento no caso das fêmeas poderia até ser um estímulo para aproximação e até para agressão no caso dos machos. Embora seja difícil obter conclusões definitivas a partir dos dados de neuroquímica, pode-se até inferir que o relatado aumento no turnover de noradrenalina no Córtex frontal, corrobore não só com resposta do estresse do SNAS, como também com o aumento do comportamento de agressão. 
Neste estudo, analisamos também a expressão gênica de citocinas no Sistema Nervoso Central, mais especificamente, IL-1, IL-6 e TNF- $\alpha$ em hipotálamo e córtex frontal. Citocinas e quimiocinas centrais são sintetizadas pelas células da glia e neurônios, e possuem diversas funções nessas mesmas células através de interações com receptores específicos na superfície (BENVENISTE, 1998). A IL-1 é uma citocina pró-inflamatória e uma das mais importantes envolvidas nas respostas neuroendócrinas e neurocomportamentais. Evidências em estudos com animais e humanos têm demonstrado que muitos tipos de estressores, por exemplo, desafios imunológicos ou psicológicos, induzem a produção desta citocina na periferia e no SNC. Os dados de Goshen et al. (2009) sugerem que a secreção de noradrenalina e sua ação em receptores $\beta$-adrenérgicos, possa ter desencadeado uma produção rápida ou liberação desta citocina pré-armazenada no SNC, fato que discorda doas agora observados, pois não encontramos alterações de IL-1 no SNC em animais CAD.

Induzida pelo estresse, a produção de IL-1também afeta diversos sistemas fisiológicos e comportamentais, incluindo-se afim, modulação neuroendócrina, febre, alterações em parâmetros imunes periféricos e sintomas de comportamento da doença.Um dos principais efeitos da elevação de IL-1 no cérebro é a ativação do eixo HPA. Esta ativação parece envolver os efeitos desta citocina no hipotálamo em especial, na neurotransmissão noradrenérgica, sugerindo que a relação entre a IL-1central e o sistema noradrenérgico é uma via bi-direcional (GOSHEN; YIRMIYA, 2009). Neste sentido, a ausência de alterações nos níveis de IL-1 no SNC dos animais CAD concorda com os dados de ausência da ativação do eixo HPA nos mesmos animais.

O TNF- $\alpha$ é também uma citocina pró-inflamatória, que após ligação em seus receptores nas células-alvo no SNC, dispara uma cascata de sinalização que controla processos celulares relacionados com a viabilidade celular, coma homeostase iônica e a integridade sináptica. No SNC o TNF- $\alpha$ é produzido por astrócitos, microglia residentes, e neurônios em resposta a numerosos estímulos intrínsecos e extrínsecos. De forma geral, seu papel como um mediador inflamatório central se faz como regulador dos processos fisiológicos centrais (PARK; BOWERS, 2010; MONTGOMERY; BOWERS, 2012). A IL-6, por sua vez, no SNC pode estar presente em derrames cerebrais, injúrias, infecções e inflamações. Portanto e de forma geral, parece ter a função de neuroproteção endógena mais marcante (BENVENISTE, 1998). Pesquisas recentes, ressaltam que sua função é proteger o tecido, impedindo a propagação da infecção e, eventualmente, restaurar a homeostase. $\mathrm{O}$ TNF- $\alpha$ apresenta os mesmos efeitos paradoxais da IL-6 no SNC (SPOOREN et al., 2011). No presente trabalho, as expressões destas citocinas (IL-1, TNF- $\alpha$ e IL-6) não apresentaram 
diferenças estatísticas significantes comparando-se os grupo CAS e CAD, isto sugere que o tipo de estresse a que os camundongos foram submetidos não tenha sido tão relevante a ponto de ativar a produção destas citocinas no SNC, este fato corrobora com os dados de campo aberto em relação ao comportamento nos machos e teria idêntica explicação. No entanto, ainda não temos dados de expressão destas citocinas no SNC de fêmeas para fazer as devidas correlações. 


\section{CONCLUSÃO}

\subsection{CONCLUSÕES ESPECÍFICAS}

Conclui-se a partir dos resultados obtidos que a convivência de camundongos machos com outro doente:

- Não alterou os níveis séricos de costicosterona, corroborando dados anteriores analisados pelo nosso grupo da ausência de participação do eixo HPA neste tipo de estresse.

- Não alterou o peso relativo da glândula adrenal.

- Aumentou os níveis plasmáticos de adrenalina e noradrenalina, confirmando a participação do SNAS neste tipo de estresse.

- Reduziu o burst oxidativo induzido por PMA e S. aureus, porém não alterou a intensidade nem a porcentagem de fagocitose em machos.

- Diminuiu a resistência ao desenvolvimento de um tumor ascítico de Ehrlich, avaliado através da concentração de células tumorais/ml de líquido ascítico e do número de células tumorais totais, não modificando o volume deste liquido.

- Aumentou os níveis de TNF $\alpha$, INF- $\gamma$ e IL-6 após 24 horas e TNF- $\alpha$ e IL-6 após 48 horas de encubação de esplenócitos com estímulo com LPS.

- Não modificou o comportamento destes animais analisados no campo aberto.

- Aumentou o turnover de noradrenalina no córtex frontal, diminuiu os níveis de noradrenalina no bulbo olfatório, diminuiu os níveis do metabólito da dopamina HVA no hipotálamo e bulbo e aumentou os níveis de serotonina e seu metabólito 5HIAA em córtex frontal.

- Não alterou a expressão das citocinas IL-1, IL-6 e TNF- $\alpha$ no hipotálamo e córtex frontal. 


\subsection{CONCLUSÃO GERAL}

Em seu conjunto, os presentes resultados mostram que a convivência de camundongos machos com portadores de um tumor ascítico de Ehrlich, que representou uma situação de estresse psicológico prolongado para os animais ativando o SNS dos mesmos, porém menos efetiva em produzir alterações comportamentais e imunes que em fêmeas. As diferenças observadas foram interpretadas como decorrentes do dimorfismo sexual, em especial no tocante ao papel etológico representado pelo desafio da convivência com doentes em machos e fêmeas. 


\section{REFERÊNCIAS}

ABBAS, A. K.; MURPHY, K. M.; SHER, A. Functional diversity of helper T lymphocytes. Nature, v. 383, n. 6603, p. 787-793, 1996.

ABERCROMBIE, E. D.; KELLER, R. W., JR.; ZIGMOND, M. J. Characterization of hippocampal norepinephrine release as measured by microdialysis perfusion: pharmacological and behavioral studies. Neuroscience, v. 27, n. 3, p. 897-904, 1988.

ABERCROMBIE, E. D.; KEEFE, K. A.; DIFRISCHIA, D. S.; ZIGMOND, M. J. Differential effect of stress on in vivo dopamine release in striatum, nucleus accumbens, and medial frontal cortex. J Neurochem, v. 52, n. 5, p. 1655-1658, 1989.

ACKERMAN, L. S. Sex hormones and the genesis of autoimmunity. Arch Dermatol, v. 142, n. 3, p. 371-376, 2006.

ADER, R. On the development of psychoneuroimmunology. Eur J Pharmacol, v. 405, n. 13, p. 167-176, 2000.

ADER, R.; KELLEY, K. W. A global view of twenty years of Brain, Behavior, and Immunity. Brain Behav Immun, v. 21, n. 1, p. 20-22, 2007.

AHMED, S. A.; TALAL, N. Sex hormones and the immune system--Part 2. Animal data. Baillieres Clin Rheumatol, v. 4, n. 1, p. 13-31, 1990.

ALPI, A.; COCCHI, A.; MENEGHELLI, A.; PAFUMI, N.; PATELLI, G. [Working with families in the early stages of psychosis: a structured intervention for caregivers]. G Ital Med Lav Ergon, v. 30, n. 3 Suppl B, p. B62-70, 2008.

ALVES, G. J.; VISMARI, L.; FLORIO, J. C.; PALERMO-NETO, J. Cohabitation with a sick cage mate: Effects on noradrenaline turnover and neutrophil activity. Neurosci Res, v. 56, n. 2, p. 172-179, 2006.

ALVES, G. J.; PALERMO-NETO, J. [Neuroimmunomodulation: the cross-talk between nervous and immune systems]. Rev Bras Psiquiatr, v. 29, n. 4, p. 363-369, 2007.

ALVES, G. J.; VISMARI, L.; PALERMO-NETO, J. Cohabitation with a sick cage mate: effects on ascitic form of Ehrlich tumor growth and macrophage activity.

Neuroimmunomodulation, v. 14, n. 6, p. 297-303, 2007. 
ALVES, G. J.; VISMARI, L.; LAZZARINI, R.; MERUSSE, J. L.; PALERMO-NETO, J. Odor cues from tumor-bearing mice induces neuroimmune changes. Behav Brain Res, v. 214, n. 2, p. 357-367, 2010.

ALVES, G. J.; RIBEIRO, A.; PALERMO-NETO, J. The neuroimmune changes induced by cohabitation with an Ehrlich tumor-bearing cage mate rely on olfactory information. Brain

Behav Immun, v. 26, n. 1, p. 32-39, 2012.

ANDERSEN, B. L.; FARRAR, W. B.; GOLDEN-KREUTZ, D. M.; GLASER, R.; EMERY, C. F.; CRESPIN, T. R.; SHAPIRO, C. L.; CARSON, W. E., 3RD. Psychological, behavioral, and immune changes after a psychological intervention: a clinical trial. J Clin Oncol, v. 22, n. 17, p. 3570-3580, 2004.

ANSAR AHMED, S.; PENHALE, W. J.; TALAL, N. Sex hormones, immune responses, and autoimmune diseases. Mechanisms of sex hormone action. Am J Pathol, v. 121, n. 3, p. 531$551,1985$.

ASCHBACHER, K.; O'DONOVAN, A.; WOLKOWITZ, O. M.; DHABHAR, F. S.; SU, Y.; EPEL, E. Good stress, bad stress and oxidative stress: Insights from anticipatory cortisol reactivity. Psychoneuroendocrinology, v., n., p., 2013.

AVITSUR, R.; POLLAK, Y.; YIRMIYA, R. Different receptor mechanisms mediate the effects of endotoxin and interleukin-1 on female sexual behavior. Brain Res, v. 773, n. 1-2, p. 149-161, 1997.

AVITSUR, R.; YIRMIYA, R. The immunobiology of sexual behavior: gender differences in the suppression of sexual activity during illness. Pharmacol Biochem Behav, v. 64, n. 4, p. 787-796, 1999.

AZPIROZ, A.; DE MIGUEL, Z.; FANO, E.; VEGAS, O. Relations between different coping strategies for social stress, tumor development and neuroendocrine and immune activity in male mice. Brain Behav Immun, v. 22, n. 5, p. 690-698, 2008.

BARTOLOMUCCI, A. Social stress, immune functions and disease in rodents. Front Neuroendocrinol, v. 28, n. 1, p. 28-49, 2007.

BASHIR, M. E.; LOUIE, S.; SHI, H. N.; NAGLER-ANDERSON, C. Toll-like receptor 4 signaling by intestinal microbes influences susceptibility to food allergy. J Immunol, v. 172, n. 11, p. 6978-6987, 2004.

BASSO, A. S.; PINTO, F. A.; RUSSO, M.; BRITTO, L. R.; DE SA-ROCHA, L. C.; PALERMO NETO, J. Neural correlates of IgE-mediated food allergy. J Neuroimmunol, v. 140, n. 1-2, p. 69-77, 2003. 
BAUER, M. E.; VEDHARA, K.; PERKS, P.; WILCOCK, G. K.; LIGHTMAN, S. L.; SHANKS, N. Chronic stress in caregivers of dementia patients is associated with reduced lymphocyte sensitivity to glucocorticoids. J Neuroimmunol, v. 103, n. 1, p. 84-92, 2000.

BEBO, B. F., JR.; SCHUSTER, J. C.; VANDENBARK, A. A.; OFFNER, H. Androgens alter the cytokine profile and reduce encephalitogenicity of myelin-reactive T cells. J Immunol, v. 162 , n. 1, p. 35-40, 1999.

BEKESI, G.; KAKUCS, R.; VARBIRO, S.; RACZ, K.; SPRINTZ, D.; FEHER, J.; SZEKACS, B. In vitro effects of different steroid hormones on superoxide anion production of human neutrophil granulocytes. Steroids, v. 65, n. 12, p. 889-894, 2000.

BELLIN, M. H.; KUB, J.; FRICK, K. D.; BOLLINGER, M. E.; TSOUKLERIS, M.; WALKER, J.; LAND, C.; BUTZ, A. M. Stress and quality of life in caregivers of inner-city minority children with poorly controlled asthma. J Pediatr Health Care, v. 27, n. 2, p. 127134, 2013.

BENSCHOP, R. J.; RODRIGUEZ-FEUERHAHN, M.; SCHEDLOWSKI, M. Catecholamine-induced leukocytosis: early observations, current research, and future directions. Brain Behav Immun, v. 10, n. 2, p. 77-91, 1996.

BENTEN, W. P.; LIEBERHERR, M.; GIESE, G.; WREHLKE, C.; STAMM, O.; SEKERIS, C. E.; MOSSMANN, H.; WUNDERLICH, F. Functional testosterone receptors in plasma membranes of T cells. FASEB J, v. 13, n. 1, p. 123-133, 1999.

BENTEN, W. P.; STEPHAN, C.; WUNDERLICH, F. B cells express intracellular but not surface receptors for testosterone and estradiol. Steroids, v. 67, n. 7, p. 647-654, 2002.

BENVENISTE, E. N. Cytokine actions in the central nervous system. Cytokine Growth Factor Rev, v. 9, n. 3-4, p. 259-275, 1998.

BESEDOVSKY, H.; SORKIN, E.; KELLER, M.; MULLER, J. Changes in blood hormone levels during the immune response. Proc Soc Exp Biol Med, v. 150, n. 2, p. 466-470, 1975.

BESEDOVSKY, H.; SORKIN, E.; FELIX, D.; HAAS, H. Hypothalamic changes during the immune response. Eur J Immunol, v. 7, n. 5, p. 323-325, 1977.

BESEDOVSKY, H.; SORKIN, E. Network of immune-neuroendocrine interactions. Clin Exp Immunol, v. 27, n. 1, p. 1-12, 1977.

BESEDOVSKY, H.; DEL REY, A.; SORKIN, E.; DINARELLO, C. A. Immunoregulatory feedback between interleukin-1 and glucocorticoid hormones. Science, v. 233, n. 4764, p. 652-654, 1986. 
BESEDOVSKY, H. O.; DEL REY, A. The cytokine-HPA axis feed-back circuit. $\mathbf{Z}$ Rheumatol, v. 59 Suppl 2, n., p. II/26-30, 2000.

BLALOCK, J. E. The syntax of immune-neuroendocrine communication. Immunol Today, v. 15, n. 11, p. 504-511, 1994.

BLOTTA, M. H.; DEKRUYFF, R. H.; UMETSU, D. T. Corticosteroids inhibit IL-12 production in human monocytes and enhance their capacity to induce IL-4 synthesis in CD4+ lymphocytes. J Immunol, v. 158, n. 12, p. 5589-5595, 1997.

BLUTHE, R. M.; MICHAUD, B.; POLI, V.; DANTZER, R. Role of IL-6 in cytokineinduced sickness behavior: a study with IL-6 deficient mice. Physiol Behav, v. 70, n. 3-4, p. 367-373, 2000.

BORGER, P.; HOEKSTRA, Y.; ESSELINK, M. T.; POSTMA, D. S.; ZAAGSMA, J.; VELLENGA, E.; KAUFFMAN, H. F. Beta-adrenoceptor-mediated inhibition of IFN-gamma, IL-3, and GM-CSF mRNA accumulation in activated human T lymphocytes is solely mediated by the beta2-adrenoceptor subtype. Am J Respir Cell Mol Biol, v. 19, n. 3, p. 400407, 1998.

BOTTASSO, O.; BAY, M. L.; BESEDOVSKY, H.; DEL REY, A. Immunoendocrine alterations during human tuberculosis as an integrated view of disease pathology.

Neuroimmunomodulation, v. 16, n. 2, p. 68-77, 2009.

BOUMAN, A.; SCHIPPER, M.; HEINEMAN, M. J.; FAAS, M. M. Gender difference in the non-specific and specific immune response in humans. Am J Reprod Immunol, v. 52, n. 1, p. 19-26, 2004.

BOUMAN, A.; HEINEMAN, M. J.; FAAS, M. M. Sex hormones and the immune response in humans. Hum Reprod Update, v. 11, n. 4, p. 411-423, 2005.

BROUG-HOLUB, E.; PERSOONS, J. H.; SCHORNAGEL, K.; MASTBERGEN, S. C.; KRAAL, G. Effects of stress on alveolar macrophages: a role for the sympathetic nervous system. Am J Respir Cell Mol Biol, v. 19, n. 5, p. 842-848, 1998.

BUGAJSKI, J. Social stress adapts signaling pathways involved in stimulation of the hypothalamic-pituitary-adrenal axis. J Physiol Pharmacol, v. 50, n. 3, p. 367-379, 1999.

CAO, L.; LAWRENCE, D. A. Suppression of host resistance to Listeria monocytogenes by acute cold/restraint stress: lack of direct IL-6 involvement. J Neuroimmunol, v. 133, n. 1-2, p. 132-143, 2002. 
CAO, L.; HUDSON, C. A.; LAWRENCE, D. A. Immune changes during acute cold/restraint stress-induced inhibition of host resistance to Listeria. Toxicol Sci, v. 74, n. 2, p. 325-334, 2003.

CARLSON, J. N.; HERRICK, K. F.; BAIRD, J. L.; GLICK, S. D. Selective enhancement of dopamine utilization in the rat prefrontal cortex by food deprivation. Brain Res, v. 400, n. 1, p. 200-203, 1987.

CASSIDY, R. A. Influence of steroids on oxidant generation in activated human granulocytes and mononuclear leukocytes. Shock, v. 20, n. 1, p. 85-90, 2003.

CHARMANDARI, E.; TSIGOS, C.; CHROUSOS, G. Endocrinology of the stress response. Annu Rev Physiol, v. 67, n., p. 259-284, 2005.

CHARNEY, D. S.; HENINGER, G. R. Noradrenergic function and the mechanism of action of antianxiety treatment. I. The effect of long-term alprazolam treatment. Arch Gen Psychiatry, v. 42, n. 5, p. 458-467, 1985.

COHEN, J. H.; DANEL, L.; CORDIER, G.; SAEZ, S.; REVILLARD, J. P. Sex steroid receptors in peripheral T cells: absence of androgen receptors and restriction of estrogen receptors to OKT8-positive cells. J Immunol, v. 131, n. 6, p. 2767-2771, 1983.

COHEN, S.; HERBERT, T. B. Health psychology: psychological factors and physical disease from the perspective of human psychoneuroimmunology. Annu Rev Psychol, v. 47, n., p. 113-142, 1996.

COHN, D. W.; KINOSHITA, D.; PALERMO-NETO, J. Antidepressants prevent hierarchy destabilization induced by lipopolysaccharide administration in mice: a neurobiological approach to depression. Ann N Y Acad Sci, v. 1262, n., p. 67-73, 2012.

CONTI, A. Oncology in neuroimmunomodulation. What progress has been made? Ann N Y Acad Sci, v. 917, n., p. 68-83, 2000.

COSTA-PINTO, F. A.; BASSO, A. S.; BRITTO, L. R.; MALUCELLI, B. E.; RUSSO, M. Avoidance behavior and neural correlates of allergen exposure in a murine model of asthma.

Brain Behav Immun, v. 19, n. 1, p. 52-60, 2005.

COSTA-PINTO, F. A.; BASSO, A. S.; DE SA-ROCHA, L. C.; BRITTO, L. R.; RUSSO, M.; PALERMO-NETO, J. Neural correlates of IgE-mediated allergy. Ann N Y Acad Sci, v. 1088, n., p. 116-131, 2006. 
COSTA-PINTO, F. A.; COHN, D. W.; SA-ROCHA, V. M.; SA-ROCHA, L. C.; PALERMONETO, J. Behavior: a relevant tool for brain-immune system interaction studies. Ann N Y Acad Sci, v. 1153, n., p. 107-119, 2009.

COSTA-PINTO, F. A.; PALERMO-NETO, J. Neuroimmune interactions in stress. Neuroimmunomodulation, v. 17, n. 3, p. 196-199, 2010.

CUNNICK, J. E.; LYSLE, D. T.; KUCINSKI, B. J.; RABIN, B. S. Evidence that shockinduced immune suppression is mediated by adrenal hormones and peripheral beta-adrenergic receptors. Pharmacol Biochem Behav, v. 36, n. 3, p. 645-651, 1990.

DANTZER, R.; KELLEY, K. W. Twenty years of research on cytokine-induced sickness behavior. Brain Behav Immun, v. 21, n. 2, p. 153-160, 2007.

DAVIDSON, P. L.; MILBURN, P. D.; WILSON, B. D. Biological adaptive control model: a mechanical analogue of multi-factorial bone density adaptation. J Theor Biol, v. 227, n. 2, p. 187-195, 2004.

DE KLOET, E. R.; SUTANTO, W.; ROTS, N.; VAN HAARST, A.; VAN DEN BERG, D.; OITZL, M.; VAN EEKELEN, A.; VOORHUIS, D. Plasticity and function of brain corticosteroid receptors during aging. Acta Endocrinol (Copenh), v. 125 Suppl 1, n., p. 6572, 1991.

DE OLIVEIRA, A. P.; LINO-DOS-SANTOS-FRANCO, A.; HAMASATO, E. K.; QUINTEIRO-FILHO, W.; HEBEDA, C. B.; DAMAZO, A. S.; FARSKY, S. H.; TAVARESDE-LIMA, W.; PALERMO-NETO, J. Amphetamine modulates cellular recruitment and airway reactivity in a rat model of allergic lung inflammation. Toxicol Lett, v. 200, n. 1-2, p. 117-123, 2011.

DE PAULA, V. F.; RIBEIRO, A.; PINHEIRO, M. L.; SAKAI, M.; LACAVA, M. C.; LAPACHINSKE, S. F.; MOREAU, R. L.; PALERMO-NETO, J.

Methylenedioxymethamphetamine (Ecstasy) decreases neutrophil activity and alters leukocyte distribution in bone marrow, spleen and blood. Neuroimmunomodulation, v. 16, n. 3, p. 191-200, 2009.

DEAKIN, J. F.; GRAEFF, F. G. 5-HT and mechanisms of defence. J Psychopharmacol, v. 5, n. 4, p. 305-315, 1991.

DEL REY, A.; BESEDOVSKY, H.; SORKIN, E.; DINARELLO, C. A. Interleukin-1 and glucocorticoid hormones integrate an immunoregulatory feedback circuit. Ann N Y Acad Sci, v. 496, n., p. 85-90, 1987. 
DEL REY, A.; KABIERSCH, A.; PETZOLDT, S.; BESEDOVSKY, H. O. Involvement of noradrenergic nerves in the activation and clonal deletion of $\mathrm{T}$ cells stimulated by superantigen in vivo. J Neuroimmunol, v. 127, n. 1-2, p. 44-53, 2002.

DHABHAR, F. S.; MCEWEN, B. S. Enhancing versus suppressive effects of stress hormones on skin immune function. Proc Natl Acad Sci U S A, v. 96, n. 3, p. 1059-1064, 1999.

DHABHAR, F. S. Stress-induced augmentation of immune function--the role of stress hormones, leukocyte trafficking, and cytokines. Brain Behav Immun, v. 16, n. 6, p. 785-798, 2002.

DHABHAR, F. S. Stress, leukocyte trafficking, and the augmentation of skin immune function. Ann N Y Acad Sci, v. 992, n., p. 205-217, 2003.

DINARELLO, C. A.; MIER, J. W. Lymphokines. N Engl J Med, v. 317, n. 15, p. 940-945, 1987.

DIORIO, D.; VIAU, V.; MEANEY, M. J. The role of the medial prefrontal cortex (cingulate gyrus) in the regulation of hypothalamic-pituitary-adrenal responses to stress. J Neurosci, v. 13, n. 9, p. 3839-3847, 1993.

DUNN, A. J. Mechanisms by which cytokines signal the brain. Int Rev Neurobiol, v. 52, n., p. 43-65, 2002.

DUNN, E.; BROWN, C.; LOVE, B. Decreasing anxiety. J Health Care Mark, v. 15, n. 1, p. 21-23, 1995.

ELENKOV, I. J.; PAPANICOLAOU, D. A.; WILDER, R. L.; CHROUSOS, G. P. Modulatory effects of glucocorticoids and catecholamines on human interleukin-12 and interleukin-10 production: clinical implications. Proc Assoc Am Physicians, v. 108, n. 5, p. 374-381, 1996.

ELENKOV, I. J.; CHROUSOS, G. P. Stress Hormones, Th1/Th2 patterns, Pro/Antiinflammatory Cytokines and Susceptibility to Disease. Trends Endocrinol Metab, v. 10, n. 9, p. 359-368, 1999.

ELENKOV, I. J.; WILDER, R. L.; CHROUSOS, G. P.; VIZI, E. S. The sympathetic nerve-an integrative interface between two supersystems: the brain and the immune system.

Pharmacol Rev, v. 52, n. 4, p. 595-638, 2000. 
ELENKOV, I. J.; CHROUSOS, G. P. Stress hormones, proinflammatory and antiinflammatory cytokines, and autoimmunity. Ann N Y Acad Sci, v. 966, n., p. 290-303, 2002.

ELENKOV, I. J. Glucocorticoids and the Th1/Th2 balance. Ann N Y Acad Sci, v. 1024, n., p. 138-146, 2004.

ELSBACH, P.; WEISS, J. A reevaluation of the roles of the O2-dependent and O2independent microbicidal systems of phagocytes. Rev Infect Dis, v. 5, n. 5, p. 843-853, 1983.

ENGLER, H.; DAWILS, L.; HOVES, S.; KURTH, S.; STEVENSON, J. R.;

SCHAUENSTEIN, K.; STEFANSKI, V. Effects of social stress on blood leukocyte distribution: the role of alpha- and beta-adrenergic mechanisms. J Neuroimmunol, v. 156, n. 1-2, p. 153-162, 2004.

FELICIO, L. F.; FLORIO, J. C.; SIDER, L. H.; CRUZ-CASALLAS, P. E.; BRIDGES, R. S. Reproductive experience increases striatal and hypothalamic dopamine levels in pregnant rats. Brain Res Bull, v. 40, n. 4, p. 253-256, 1996.

FERRAZ-DE-PAULA, V.; STANKEVICIUS, D.; RIBEIRO, A.; PINHEIRO, M. L.; RODRIGUES-COSTA, E. C.; FLORIO, J. C.; LAPACHINSKE, S. F.; MOREAU, R. L.; PALERMO-NETO, J. Differential behavioral outcomes of 3,4methylenedioxymethamphetamine (MDMA-ecstasy) in anxiety-like responses in mice. Braz J Med Biol Res, v. 44, n. 5, p. 428-437, 2011.

FIDLER, I. J. Macrophages and metastasis--a biological approach to cancer therapy. Cancer Res, v. 45, n. 10, p. 4714-4726, 1985.

FISH, E. N. The X-files in immunity: sex-based differences predispose immune responses. Nat Rev Immunol, v. 8, n. 9, p. 737-744, 2008.

FONSECA, E. S.; MASSOCO, C. O.; PALERMO-NETO, J. Effects of prenatal stress on stress-induced changes in behavior and macrophage activity of mice. Physiol Behav, v. 77, n. 2-3, p. 205-215, 2002.

FREDMAN, L.; CAULEY, J. A.; HOCHBERG, M.; ENSRUD, K. E.; DOROS, G. Mortality associated with caregiving, general stress, and caregiving-related stress in elderly women: results of caregiver-study of osteoporotic fractures. J Am Geriatr Soc, v. 58, n. 5, p. 937 943, 2010.

GAVRILOVIC, L.; SPASOJEVIC, N.; DRONJAK, S. Chronic individual housing-induced stress decreased expression of catecholamine biosynthetic enzyme genes and proteins in spleen of adult rats. Neuroimmunomodulation, v. 17, n. 4, p. 265-269, 2010. 
GHAZEERI, G.; ABDULLAH, L.; ABBAS, O. Immunological differences in women compared with men: overview and contributing factors. Am J Reprod Immunol, v. 66, n. 3, p. 163-169, 2011.

GILTAY, E. J.; FONK, J. C.; VON BLOMBERG, B. M.; DREXHAGE, H. A.; SCHALKWIJK, C.; GOOREN, L. J. In vivo effects of sex steroids on lymphocyte responsiveness and immunoglobulin levels in humans. J Clin Endocrinol Metab, v. 85, n. 4, p. 1648-1657, 2000.

GLAVIN, G. B.; TANAKA, M.; TSUDA, A.; KOHNO, Y.; HOAKI, Y.; NAGASAKI, N. Regional rat brain noradrenaline turnover in response to restraint stress. Pharmacol Biochem Behav, v. 19, n. 2, p. 287-290, 1983.

GLIMCHER, L. H.; MURPHY, K. M. Lineage commitment in the immune system: the T helper lymphocyte grows up. Genes Dev, v. 14, n. 14, p. 1693-1711, 2000.

GOMEZ, F. P.; STEELMAN, A. J.; YOUNG, C. R.; WELSH, C. J. Hormone and immune system interactions in demyelinating disease. Horm Behav, v. 63, n. 2, p. 315-321, 2013.

GOSHEN, I.; YIRMIYA, R. Interleukin-1 (IL-1): a central regulator of stress responses. Front Neuroendocrinol, v. 30, n. 1, p. 30-45, 2009.

GRAEFF, F. G. [Serotonin, periaqueductal gray matter and panic disorder]. Rev Bras Psiquiatr, v. 25 Suppl 2, n., p. 42-45, 2003.

GUYRE, P. M.; GIRARD, M. T.; MORGANELLI, P. M.; MANGANIELLO, P. D. Glucocorticoid effects on the production and actions of immune cytokines. J Steroid Biochem, v. 30, n. 1-6, p. 89-93, 1988.

HADRI, K. E.; COURTALON, A.; GAUTHEREAU, X.; CHAMBAUT-GUERIN, A. M.; PAIRAULT, J.; FEVE, B. Differential regulation by tumor necrosis factor-alpha of beta1-, beta2-, and beta3-adrenoreceptor gene expression in 3T3-F442A adipocytes. J Biol Chem, v. 272, n. 39, p. 24514-24521, 1997.

HANKE, M. L.; POWELL, N. D.; STINER, L. M.; BAILEY, M. T.; SHERIDAN, J. F. Beta adrenergic blockade decreases the immunomodulatory effects of social disruption stress.

Brain Behav Immun, v. 26, n. 7, p. 1150-1159, 2012.

HART, B. L. Biological basis of the behavior of sick animals. Neurosci Biobehav Rev, v. 12, n. 2, p. 123-137, 1988. 
HASUI, M.; HIRABAYASHI, Y.; KOBAYASHI, Y. Simultaneous measurement by flow cytometry of phagocytosis and hydrogen peroxide production of neutrophils in whole blood. J Immunol Methods, v. 117, n. 1, p. 53-58, 1989.

HELDRING, N.; PIKE, A.; ANDERSSON, S.; MATTHEWS, J.; CHENG, G.; HARTMAN, J.; TUJAGUE, M.; STROM, A.; TREUTER, E.; WARNER, M.; GUSTAFSSON, J. A. Estrogen receptors: how do they signal and what are their targets. Physiol Rev, v. 87, n. 3, p. 905-931, 2007.

HILL, L.; JEGANATHAN, V.; CHINNASAMY, P.; GRIMALDI, C.; DIAMOND, B. Differential roles of estrogen receptors alpha and beta in control of B-cell maturation and selection. Mol Med, v. 17, n. 3-4, p. 211-220, 2011.

HOFER, S. O.; MOLEMA, G.; HERMENS, R. A.; WANEBO, H. J.; REICHNER, J. S.; HOEKSTRA, H. J. The effect of surgical wounding on tumour development. Eur J Surg Oncol, v. 25, n. 3, p. 231-243, 1999.

IGNATOWSKI, T. A.; GALLANT, S.; SPENGLER, R. N. Temporal regulation by adrenergic receptor stimulation of macrophage (M phi)-derived tumor necrosis factor (TNF) production post-LPS challenge. J Neuroimmunol, v. 65, n. 2, p. 107-117, 1996.

IIMORI, K.; TANAKA, M.; KOHNO, Y.; IDA, Y.; NAKAGAWA, R.; HOAKI, Y.; TSUDA, A.; NAGASAKI, N. Psychological stress enhances noradrenaline turnover in specific brain regions in rats. Pharmacol Biochem Behav, v. 16, n. 4, p. 637-640, 1982.

IWAKABE, K.; SHIMADA, M.; OHTA, A.; YAHATA, T.; OHMI, Y.; HABU, S.; NISHIMURA, T. The restraint stress drives a shift in Th1/Th2 balance toward Th2-dominant immunity in mice. Immunol Lett, v. 62, n. 1, p. 39-43, 1998.

JAHNG, J. W. An animal model of eating disorders associated with stressful experience in early life. Horm Behav, v. 59, n. 2, p. 213-220, 2011.

JIWA, M.; MITCHELL, G.; SIBBRIT, D.; GIRGIS, A.; BURRIDGE, L. Addressing the needs of caregivers of cancer patients in general practice: a complex intervention. Qual Prim Care, v. 18, n. 1, p. 9-16, 2010.

JOHNSTON, G. R.; WEBSTER, N. R. Cytokines and the immunomodulatory function of the vagus nerve. Br J Anaesth, v. 102, n. 4, p. 453-462, 2009.

JOVANOVA-NESIC, K.; NIKOLIC, V.; JANKOVIC, B. D. Locus ceruleus and immunity. II. Suppression of experimental allergic encephalomyelitis and hypersensitivity skin reactions in rats with lesioned locus ceruleus. Int J Neurosci, v. 68, n. 3-4, p. 289-294, 1993. 
KALINICHENKO, V. V.; MOKYR, M. B.; GRAF, L. H., JR.; COHEN, R. L.; CHAMBERS, D. A. Norepinephrine-mediated inhibition of antitumor cytotoxic T lymphocyte generation involves a beta-adrenergic receptor mechanism and decreased TNF-alpha gene expression. J Immunol, v. 163, n. 5, p. 2492-2499, 1999.

KAVELAARS, A. Regulated expression of alpha-1 adrenergic receptors in the immune system. Brain Behav Immun, v. 16, n. 6, p. 799-807, 2002.

KELLER, R.; KEIST, R.; BAZIN, H.; JOLLER, P.; VAN DER MEIDE, P. H. Binding of monomeric immunoglobulins by bone marrow-derived mononuclear phagocytes; its modulation by interferon-gamma. Eur J Immunol, v. 20, n. 9, p. 2137-2140, 1990.

KIECOLT-GLASER, J. K.; MARUCHA, P. T.; ATKINSON, C.; GLASER, R. Hypnosis as a modulator of cellular immune dysregulation during acute stress. J Consult Clin Psychol, v. 69, n. 4, p. 674-682, 2001.

KLEIN, S. L.; JEDLICKA, A.; PEKOSZ, A. The Xs and Y of immune responses to viral vaccines. Lancet Infect Dis, v. 10, n. 5, p. 338-349, 2010.

KOFF, W. C.; DUNEGAN, M. A. Neuroendocrine hormones suppress macrophage-mediated lysis of herpes simplex virus-infected cells. J Immunol, v. 136, n. 2, p. 705-709, 1986.

KOHM, A. P.; SANDERS, V. M. Suppression of antigen-specific Th2 cell-dependent IgM and IgG1 production following norepinephrine depletion in vivo. J Immunol, v. 162, n. 9, p. 5299-5308, 1999.

KOHM, A. P.; SANDERS, V. M. Norepinephrine: a messenger from the brain to the immune system. Immunol Today, v. 21, n. 11, p. 539-542, 2000.

KOHM, A. P.; SANDERS, V. M. Norepinephrine and beta 2-adrenergic receptor stimulation regulate CD4+ T and B lymphocyte function in vitro and in vivo. Pharmacol Rev, v. 53, n. 4, p. 487-525, 2001.

KONSMAN, J. P.; PARNET, P.; DANTZER, R. Cytokine-induced sickness behaviour: mechanisms and implications. Trends Neurosci, v. 25, n. 3, p. 154-159, 2002.

KOVALOVSKY, D.; REFOJO, D.; HOLSBOER, F.; ARZT, E. Molecular mechanisms and Th1/Th2 pathways in corticosteroid regulation of cytokine production. J Neuroimmunol, v. 109 , n. 1, p. 23-29, 2000. 
LAZZARINI, R.; MALUCELLI, B. E.; PALERMO-NETO, J. Reduction of acute inflammation in rats by diazepam: role of peripheral benzodiazepine receptors and corticosterone. Immunopharmacol Immunotoxicol, v. 23, n. 2, p. 253-265, 2001.

LAZZARINI, R.; MAIORKA, P. C.; LIU, J.; PAPADOPOULOS, V.; PALERMO-NETO, J. Diazepam effects on carrageenan-induced inflammatory paw edema in rats: role of nitric oxide. Life Sci, v. 78, n. 26, p. 3027-3034, 2006.

LE MOAL, M.; SIMON, H. Mesocorticolimbic dopaminergic network: functional and regulatory roles. Physiol Rev, v. 71, n. 1, p. 155-234, 1991.

LEHN, M.; WEISER, W. Y.; ENGELHORN, S.; GILLIS, S.; REMOLD, H. G. IL-4 inhibits $\mathrm{H} 2 \mathrm{O} 2$ production and antileishmanial capacity of human cultured monocytes mediated by IFN-gamma. J Immunol, v. 143, n. 9, p. 3020-3024, 1989.

LIBERMAN, A. C.; REFOJO, D.; ARZT, E. Cytokine signaling/transcription factor crosstalk in T cell activation and Th1-Th2 differentiation. Arch Immunol Ther Exp (Warsz), v. 51, n. 6, p. 351-365, 2003.

LIGEIRO-OLIVEIRA, A. P.; FIALHO DE ARAUJO, A. M.; LAZZARINI, R.; SILVA, Z. L.; DE NUCCI, G.; MUSCARA, M. N.; TAVARES DE LIMA, W.; PALERMO-NETO, J. Effects of amphetamine on immune-mediated lung inflammatory response in rats.

Neuroimmunomodulation, v. 11, n. 3, p. 181-190, 2004.

LIGEIRO DE OLIVEIRA, A. P.; LAZZARINI, R.; CAVRIANI, G.; QUINTEIRO-FILHO, W. M.; TAVARES DE LIMA, W.; PALERMO-NETO, J. Effects of single or repeated amphetamine treatment and withdrawal on lung allergic inflammation in rats. Int Immunopharmacol, v. 8, n. 9, p. 1164-1171, 2008.

LIGHTMAN, S. L.; WINDLE, R. J.; MA, X. M.; HARBUZ, M. S.; SHANKS, N. M.; JULIAN, M. D.; WOOD, S. A.; KERSHAW, Y. M.; INGRAM, C. D. Hypothalamicpituitary-adrenal function. Arch Physiol Biochem, v. 110, n. 1-2, p. 90-93, 2002.

LOURENCO, G. A.; DORCE, V. A.; PALERMO-NETO, J. Haloperidol treatments increased macrophage activity in male and female rats: influence of corticosterone and prolactin serum levels. Eur Neuropsychopharmacol, v. 15, n. 3, p. 271-277, 2005.

MADDEN, K. S.; FELTEN, S. Y.; FELTEN, D. L.; HARDY, C. A.; LIVNAT, S. Sympathetic nervous system modulation of the immune system. II. Induction of lymphocyte proliferation and migration in vivo by chemical sympathectomy. J Neuroimmunol, v. 49, n. 1-2, p. 67-75, 1994. 
MADDEN, K. S.; FELTEN, D. L. Experimental basis for neural-immune interactions. Physiol Rev, v. 75, n. 1, p. 77-106, 1995.

MADDEN, K. S. Catecholamines, sympathetic innervation, and immunity. Brain Behav Immun, v. 17 Suppl 1, n., p. S5-10, 2003.

MAIER, S. F. Bi-directional immune-brain communication: Implications for understanding stress, pain, and cognition. Brain Behav Immun, v. 17, n. 2, p. 69-85, 2003.

MALARKEY, W. B.; WANG, J.; CHENEY, C.; GLASER, R.; NAGARAJA, H. Human lymphocyte growth hormone stimulates interferon gamma production and is inhibited by cortisol and norepinephrine. J Neuroimmunol, v. 123, n. 1-2, p. 180-187, 2002.

MARCHETTI, B.; PLUCHINO, S. Wnt your brain be inflamed? Yes, it Wnt! Trends Mol Med, v. 19, n. 3, p. 144-156, 2013.

MARCHI-JONES, S.; MURPHY, J. F.; ROUSSEAU, P. Caring for the caregivers. J Gerontol Nurs, v. 22, n. 8, p. 7-13, 1996.

MASSOCO, C.; PALERMO-NETO, J. Effects of midazolam on equine innate immune response: a flow cytometric study. Vet Immunol Immunopathol, v. 95, n. 1-2, p. 11-19, 2003.

MATSUMURA, K.; OPIEKUN, M.; OKA, H.; VACHANI, A.; ALBELDA, S. M.; YAMAZAKI, K.; BEAUCHAMP, G. K. Urinary volatile compounds as biomarkers for lung cancer: a proof of principle study using odor signatures in mouse models of lung cancer.

PLoS One, v. 5, n. 1, p. e8819, 2010.

MCEWEN, B. S. Physiology and neurobiology of stress and adaptation: central role of the brain. Physiol Rev, v. 87, n. 3, p. 873-904, 2007.

MCMURRAY, R. W.; SUWANNAROJ, S.; NDEBELE, K.; JENKINS, J. K. Differential effects of sex steroids on T and B cells: modulation of cell cycle phase distribution, apoptosis and bcl-2 protein levels. Pathobiology, v. 69, n. 1, p. 44-58, 2001.

MELAMED, R.; ROSENNE, E.; SHAKHAR, K.; SCHWARTZ, Y.; ABUDARHAM, N.; BEN-ELIYAHU, S. Marginating pulmonary-NK activity and resistance to experimental tumor metastasis: suppression by surgery and the prophylactic use of a beta-adrenergic antagonist and a prostaglandin synthesis inhibitor. Brain Behav Immun, v. 19, n. 2, p. 114126, 2005. 
MELTZER, J. C.; MACNEIL, B. J.; SANDERS, V.; PYLYPAS, S.; JANSEN, A. H.; GREENBERG, A. H.; NANCE, D. M. Stress-induced suppression of in vivo splenic cytokine production in the rat by neural and hormonal mechanisms. Brain Behav Immun, v. 18, n. 3, p. 262-273, 2004.

MILLS, P. J.; YU, H.; ZIEGLER, M. G.; PATTERSON, T.; GRANT, I. Vulnerable caregivers of patients with Alzheimer's disease have a deficit in circulating CD62L- T lymphocytes. Psychosom Med, v. 61, n. 2, p. 168-174, 1999.

MIYAGI, M.; AOYAMA, H.; MORISHITA, M.; IWAMOTO, Y. Effects of sex hormones on chemotaxis of human peripheral polymorphonuclear leukocytes and monocytes. J

Periodontol, v. 63, n. 1, p. 28-32, 1992.

MOLLOY, E. J.; O'NEILL, A. J.; GRANTHAM, J. J.; SHERIDAN-PEREIRA, M.; FITZPATRICK, J. M.; WEBB, D. W.; WATSON, R. W. Sex-specific alterations in neutrophil apoptosis: the role of estradiol and progesterone. Blood, v. 102, n. 7, p. 2653-2659, 2003.

MONTGOMERY, S. L.; BOWERS, W. J. Tumor necrosis factor-alpha and the roles it plays in homeostatic and degenerative processes within the central nervous system. $\mathbf{J}$

Neuroimmune Pharmacol, v. 7, n. 1, p. 42-59, 2012.

MORGULIS, M. S.; STANKEVICIUS, D.; SA-ROCHA, L. C.; PALERMO-NETO, J. Cohabitation with a sick cage mate: consequences on behavior and on ehrlich tumor growth. Neuroimmunomodulation, v. 11, n. 1, p. 49-57, 2004.

NANCE, D. M.; SANDERS, V. M. Autonomic innervation and regulation of the immune system (1987-2007). Brain Behav Immun, v. 21, n. 6, p. 736-745, 2007.

NATHAN, C. F.; KARNOVSKY, M. L.; DAVID, J. R. Alterations of macrophage functions by mediators from lymphocytes. J Exp Med, v. 133, n. 6, p. 1356-1376, 1971.

NAVAIE-WALISER, M.; SPRIGGS, A.; FELDMAN, P. H. Informal caregiving: differential experiences by gender. Med Care, v. 40, n. 12, p. 1249-1259, 2002.

NEURATH, M. F.; FINOTTO, S. IL-6 signaling in autoimmunity, chronic inflammation and inflammation-associated cancer. Cytokine Growth Factor Rev, v. 22, n. 2, p. 83-89, 2011.

NIKOLIC, V.; JOVANOVA-NESIC, K.; JANKOVIC, B. D. Locus ceruleus and immunity. I. Suppression of plaque-forming cell response and antibody production in rats with lesioned locus ceruleus. Int J Neurosci, v. 68, n. 3-4, p. 283-287, 1993. 
OKA, T.; KANEMITSU, Y.; SUDO, N.; HAYASHI, H.; OKA, K. Psychological stress contributed to the development of low-grade fever in a patient with chronic fatigue syndrome: a case report. Biopsychosoc Med, v. 7, n. 1, p. 7, 2013.

PACHECO-LOPEZ, G.; NIEMI, M. B.; KOU, W.; BILDHAUSER, A.; GROSS, C. M.; GOEBEL, M. U.; DEL REY, A.; BESEDOVSKY, H. O.; SCHEDLOWSKI, M. Central catecholamine depletion inhibits peripheral lymphocyte responsiveness in spleen and blood. J Neurochem, v. 86, n. 4, p. 1024-1031, 2003.

PALERMO-NETO, J.; DE OLIVEIRA MASSOCO, C.; ROBESPIERRE DE SOUZA, W. Effects of physical and psychological stressors on behavior, macrophage activity, and Ehrlich tumor growth. Brain Behav Immun, v. 17, n. 1, p. 43-54, 2003.

PALERMO-NETO, J.; FONSECA, E. S.; QUINTEIRO-FILHO, W. M.; CORREIA, C. S.; SAKAI, M. Effects of individual housing on behavior and resistance to Ehrlich tumor growth in mice. Physiol Behav, v. 95, n. 3, p. 435-440, 2008.

PALERMO NETO, J.; MASSOCO, C. O.; FAVARE, R. C. Effects of maternal stress on anxiety levels, macrophage activity, and Ehrlich tumor growth. Neurotoxicol Teratol, v. 23, n. 5, p. 497-507, 2001.

PAMER, E. G. Immune responses to Listeria monocytogenes. Nat Rev Immunol, v. 4, n. 10, p. 812-823, 2004.

PANINA-BORDIGNON, P.; MAZZEO, D.; LUCIA, P. D.; D'AMBROSIO, D.; LANG, R.; FABBRI, L.; SELF, C.; SINIGAGLIA, F. Beta2-agonists prevent Th1 development by selective inhibition of interleukin 12. J Clin Invest, v. 100, n. 6, p. 1513-1519, 1997.

PARK, K. M.; BOWERS, W. J. Tumor necrosis factor-alpha mediated signaling in neuronal homeostasis and dysfunction. Cell Signal, v. 22, n. 7, p. 977-983, 2010.

PAUL, W. E.; SEDER, R. A. Lymphocyte responses and cytokines. Cell, v. 76, n. 2, p. 241$251,1994$.

PAVCOVICH, L. A.; CANCELA, L. M.; VOLOSIN, M.; MOLINA, V. A.; RAMIREZ, O. A. Chronic stress-induced changes in locus coeruleus neuronal activity. Brain Res Bull, v. 24, n. 2, p. 293-296, 1990.

PENNELL, L. M.; GALLIGAN, C. L.; FISH, E. N. Sex affects immunity. J Autoimmun, v. 38, n. 2-3, p. J282-291, 2012. 
PESSINA, A.; BRAMBILLA, P.; MOCARELLI, P. Surface antigen on Ehrlich ascites tumor cells. Biomedicine, v. 33, n. 4, p. 105-109, 1980.

PHILLIPS, M.; GLEESON, K.; HUGHES, J. M.; GREENBERG, J.; CATANEO, R. N.; BAKER, L.; MCVAY, W. P. Volatile organic compounds in breath as markers of lung cancer: a cross-sectional study. Lancet, v. 353, n. 9168, p. 1930-1933, 1999.

PHILLIPS, M.; CATANEO, R. N.; CUMMIN, A. R.; GAGLIARDI, A. J.; GLEESON, K.; GREENBERG, J.; MAXFIELD, R. A.; ROM, W. N. Detection of lung cancer with volatile markers in the breath. Chest, v. 123, n. 6, p. 2115-2123, 2003.

QIU, Y. H.; CHENG, C.; DAI, L.; PENG, Y. P. Effect of endogenous catecholamines in lymphocytes on lymphocyte function. J Neuroimmunol, v. 167, n. 1-2, p. 45-52, 2005.

QUEIROZ JDE, S.; TORELLO, C. O.; PALERMO-NETO, J.; VALADARES, M. C.; QUEIROZ, M. L. Hematopoietic response of rats exposed to the impact of an acute psychophysiological stressor on responsiveness to an in vivo challenge with Listeria monocytogenes: modulation by Chlorella vulgaris prophylactic treatment. Brain Behav Immun, v. 22, n. 7, p. 1056-1065, 2008.

REFOJO, D.; LIBERMAN, A. C.; GIACOMINI, D.; CARBIA NAGASHIMA, A.; GRACIARENA, M.; ECHENIQUE, C.; PAEZ PEREDA, M.; STALLA, G.; HOLSBOER, F.; ARZT, E. Integrating systemic information at the molecular level: cross-talk between steroid receptors and cytokine signaling on different target cells. Ann N Y Acad Sci, v. 992, n., p. 196-204, 2003.

REICHE, E. M.; NUNES, S. O.; MORIMOTO, H. K. Stress, depression, the immune system, and cancer. Lancet Oncol, v. 5, n. 10, p. 617-625, 2004.

REICHLIN, S. Neuroendocrine-immune interactions. N Engl J Med, v. 329, n. 17, p. 12461253, 1993.

RIBEIRO, A.; FERRAZ-DE-PAULA, V.; PINHEIRO, M. L.; PALERMO-NETO, J. Doseresponse effects of systemic anandamide administration in mice sequentially submitted to the open field and elevated plus-maze tests. Braz J Med Biol Res, v. 42, n. 6, p. 556-560, 2009.

RIBEIRO, A.; FERRAZ-DE-PAULA, V.; PINHEIRO, M. L.; SAKAI, M.; COSTA-PINTO, F. A.; PALERMO-NETO, J. Anandamide prior to sensitization increases cell-mediated immunity in mice. Int Immunopharmacol, v. 10, n. 4, p. 431-439, 2010. 
ROGGERO, E.; PEREZ, A. R.; BOTTASSO, O. A.; BESEDOVSKY, H. O.; DEL REY, A. Neuroendocrine-immunology of experimental Chagas' disease. Ann N Y Acad Sci, v. 1153, n., p. 264-271, 2009.

ROTH, K. A.; MEFFORD, I. M.; BARCHAS, J. D. Epinephrine, norepinephrine, dopamine and serotonin: differential effects of acute and chronic stress on regional brain amines. Brain Res, v. 239, n. 2, p. 417-424, 1982.

ROMAGNANI, S. The Th1/Th2 paradigm. Immunol Today, v. 18, n. 6, p. 263-266, 1997.

ROTH, R. H.; TAM, S. Y.; IDA, Y.; YANG, J. X.; DEUTCH, A. Y. Stress and the mesocorticolimbic dopamine systems. Ann N Y Acad Sci, v. 537, n., p. 138-147, 1988.

ROTHWELL, N. J.; HOPKINS, S. J. Cytokines and the nervous system II: Actions and mechanisms of action. Trends Neurosci, v. 18, n. 3, p. 130-136, 1995.

RUBTSOV, A. V.; RUBTSOVA, K.; KAPPLER, J. W.; MARRACK, P. Genetic and hormonal factors in female-biased autoimmunity. Autoimmun Rev, v. 9, n. 7, p. 494-498, 2010 .

SA-ROCHA, V. M.; SA-ROCHA, L. C.; PALERMO-NETO, J. Variations in behavior, innate immunity and host resistance to $\mathrm{B} 16 \mathrm{~F} 10$ melanoma growth in mice that present social stable hierarchical ranks. Physiol Behav, v. 88, n. 1-2, p. 108-115, 2006.

SAKAI, M.; FONSECA, E. S.; DAGLI, M. L.; PALERMO-NETO, J. Diazepam effects on Ehrlich tumor growth and macrophage activity in mice. Life Sci, v. 78, n. 16, p. 1777-1783, 2006a.

SAKAI, M.; FONSECA, E. S.; OLORIS, S. C.; MATSUZAKI, P.; OTAKE, A. H.; LEITE, K. R.; MASSOCO, C. O.; DAGLI, M. L.; PALERMO-NETO, J. Effects of peripheral-type benzodiazepine receptor ligands on Ehrlich tumor cell proliferation. Eur J Pharmacol, v. 550, n. 1-3, p. 8-14, 2006 .

SAPOLSKY, R. M.; ROMERO, L. M.; MUNCK, A. U. How do glucocorticoids influence stress responses? Integrating permissive, suppressive, stimulatory, and preparative actions. Endocr Rev, v. 21, n. 1, p. 55-89, 2000.

SCHEDLOWSKI, M.; JACOBS, R.; STRATMANN, G.; RICHTER, S.; HADICKE, A.; TEWES, U.; WAGNER, T. O.; SCHMIDT, R. E. Changes of natural killer cells during acute psychological stress. J Clin Immunol, v. 13, n. 2, p. 119-126, 1993. 
SCHONEVELD, O. J.; HOOGENKAMP, M.; STALLEN, J. M.; GAEMERS, I. C.; LAMERS, W. H. cyclicAMP and glucocorticoid responsiveness of the rat carbamoylphosphate synthetase gene requires the interplay of upstream regulatory units. Biochimie, v. 89, n. 5, p. 574-580, 2007.

SEGURA, J. A.; BARBERO, L. G.; MARQUEZ, J. Early tumor effect on splenic Th lymphocytes in mice. FEBS Lett, v. 414, n. 1, p. 1-6, 1997.

SELI, E.; KAYISLI, U. A.; SELAM, B.; SELI, M.; ARICI, A. Estradiol suppresses vascular monocyte chemotactic protein-1 expression during early atherogenesis. Am J Obstet Gynecol, v. 187, n. 6, p. 1544-1549, 2002.

SELYE, H. A syndrome produced by diverse nocuous agents. 1936. J Neuropsychiatry Clin Neurosci, v. 10, n. 2, p. 230-231, 1998.

SHAMES, R. S. Gender differences in the development and function of the immune system. J Adolesc Health, v. 30, n. 4 Suppl, p. 59-70, 2002.

SIETSES, C.; BEELEN, R. H.; MEIJER, S.; CUESTA, M. A. Immunological consequences of laparoscopic surgery, speculations on the cause and clinical implications. Langenbecks Arch Surg, v. 384, n. 3, p. 250-258, 1999.

SIMSON, P. E.; WEISS, J. M. Altered activity of the locus coeruleus in an animal model of depression. Neuropsychopharmacology, v. 1, n. 4, p. 287-295, 1988.

SO, E. Y.; KIM, S. H.; PARK, H. H.; CHO, B. S.; LEE, C. E. Corticosteroid inhibits IL-4 signaling through down-regulation of IL-4 receptor and STAT6 activity. FEBS Lett, v. 518, n. $1-3$, p. 53-59, 2002.

SOLOMON, G. F.; AMKRAUT, A. A. Psychoneuroendocrinological effects on the immune response. Annu Rev Microbiol, v. 35, n., p. 155-184, 1981.

SPOOREN, A.; KOLMUS, K.; LAUREYS, G.; CLINCKERS, R.; DE KEYSER, J.; HAEGEMAN, G.; GERLO, S. Interleukin-6, a mental cytokine. Brain Res Rev, v. 67, n. 1-2, p. 157-183, 2011.

STANKEVICIUS, D.; RODRIGUES-COSTA, E. C.; CAMILO FLORIO, J.; PALERMONETO, J. Neuroendocrine, behavioral and macrophage activity changes induced by picrotoxin effects in mice. Neuropharmacology, v. 54, n. 2, p. 300-308, 2008.

STEINBERG, A. D.; MELEZ, K. A.; RAVECHE, E. S.; REEVES, J. P.; BOEGEL, W. A.; SMATHERS, P. A.; TAUROG, J. D.; WEINLEIN, L.; DUVIC, M. Approach to the study of 
the role of sex hormones in autoimmunity. Arthritis Rheum, v. 22, n. 11, p. 1170-1176, 1979.

STRANGE, K. S.; KERR, L. R.; ANDREWS, H. N.; EMERMAN, J. T.; WEINBERG, J. Psychosocial stressors and mammary tumor growth: an animal model. Neurotoxicol Teratol, v. 22, n. 1, p. 89-102, 2000.

STROTH, N.; KURI, B. A.; MUSTAFA, T.; CHAN, S. A.; SMITH, C. B.; EIDEN, L. E. PACAP controls adrenomedullary catecholamine secretion and expression of catecholamine biosynthetic enzymes at high splanchnic nerve firing rates characteristic of stress transduction in male mice. Endocrinology, v. 154, n. 1, p. 330-339, 2013.

SUGIMOTO, Y.; OGAWA, M.; TAI, N.; KAMEI, C. Inhibitory effects of glucocorticoids on rat eosinophil superoxide generation and chemotaxis. Int Immunopharmacol, v. 3, n. 6, p. 845-852, 2003.

SULLIVAN, D. A.; HANN, L. E. Hormonal influence on the secretory immune system of the eye: endocrine impact on the lacrimal gland accumulation and secretion of $\operatorname{IgA}$ and $\operatorname{IgG}$. $\mathbf{J}$

Steroid Biochem, v. 34, n. 1-6, p. 253-262, 1989.

TANRIVERDI, F.; SILVEIRA, L. F.; MACCOLL, G. S.; BOULOUX, P. M. The hypothalamic-pituitary-gonadal axis: immune function and autoimmunity. J Endocrinol, v. 176, n. 3, p. 293-304, 2003.

TILAN, J.; KITLINSKA, J. Sympathetic Neurotransmitters and Tumor Angiogenesis-Link between Stress and Cancer Progression. J Oncol, v. 2010, n., p. 539706, 2010.

TOMIYOSHI, M. Y.; SAKAI, M.; BALEEIRO, R. B.; STANKEVICIUS, D.; MASSOCO, C. O.; PALERMO-NETO, J.; BARBUTO, J. A. Cohabitation with a B16F10 melanomabearer cage mate influences behavior and dendritic cell phenotype in mice. Brain Behav Immun, v. 23, n. 4, p. 558-567, 2009.

TRACEY, K. J. The inflammatory reflex. Nature, v. 420, n. 6917, p. 853-859, 2002.

TRACEY, K. J. Physiology and immunology of the cholinergic antiinflammatory pathway. J Clin Invest, v. 117, n. 2, p. 289-296, 2007.

VALENTINO, R. J.; REYES, B.; VAN BOCKSTAELE, E.; BANGASSER, D. Molecular and cellular sex differences at the intersection of stress and arousal. Neuropharmacology, v. 62, n. 1, p. 13-20, 2012. 
VAN OVERVELD, F. J.; DEMKOW, U. A.; GORECKA, D.; ZIELINSKI, J.; DE BACKER, W. A. Inhibitory capacity of different steroids on neutrophil migration across a bilayer of endothelial and bronchial epithelial cells. Eur J Pharmacol, v. 477, n. 3, p. 261-267, 2003.

VEGAS, O.; FANO, E.; BRAIN, P. F.; ALONSO, A.; AZPIROZ, A. Social stress, coping strategies and tumor development in male mice: behavioral, neuroendocrine and immunological implications. Psychoneuroendocrinology, v. 31, n. 1, p. 69-79, 2006.

VIDRIH, B.; KARLOVIC, D.; PASIC, M. B.; UREMOVIC, M.; MUFIC, A. K.; MATOSIC, A. A review of the psychoneuroimmunologic concepts on the etiology of depressive disorders. Acta Clin Croat, v. 51, n. 3, p. 403-409, 2012.

WEBSTER, J. I.; TONELLI, L.; STERNBERG, E. M. Neuroendocrine regulation of immunity. Annu Rev Immunol, v. 20, n., p. 125-163, 2002.

WRONA, D. Neural-immune interactions: an integrative view of the bidirectional relationship between the brain and immune systems. J Neuroimmunol, v. 172, n. 1-2, p. 3858, 2006.

WU, W.; YAMAURA, T.; MURAKAMI, K.; MURATA, J.; MATSUMOTO, K.; WATANABE, H.; SAIKI, I. Social isolation stress enhanced liver metastasis of murine colon 26-L5 carcinoma cells by suppressing immune responses in mice. Life Sci, v. 66, n. 19, p. $1827-1838,2000$.

ZANDMAN-GODDARD, G.; PEEVA, E.; SHOENFELD, Y. Gender and autoimmunity. Autoimmun Rev, v. 6, n. 6, p. 366-372, 2007.

ZENEWICZ, L. A.; SHEN, H. Innate and adaptive immune responses to Listeria monocytogenes: a short overview. Microbes Infect, v. 9, n. 10, p. 1208-1215, 2007.

ZETTER, B. R. Angiogenesis and tumor metastasis. Annu Rev Med, v. 49, n., p. 407-424, 1998.

ZHOU, D.; KUSNECOV, A. W.; SHURIN, M. R.; DEPAOLI, M.; RABIN, B. S. Exposure to physical and psychological stressors elevates plasma interleukin 6: relationship to the activation of hypothalamic-pituitary-adrenal axis. Endocrinology, v. 133, n. 6, p. 2523-2530, 1993.

ZORRILLA, E. P.; LUBORSKY, L.; MCKAY, J. R.; ROSENTHAL, R.; HOULDIN, A.; TAX, A.; MCCORKLE, R.; SELIGMAN, D. A.; SCHMIDT, K. The relationship of depression and stressors to immunological assays: a meta-analytic review. Brain Behav Immun, v. 15, n. 3, p. 199-226, 2001. 